\author{
UNIVERSIDADE DE SÃO PAULO - USP \\ FACULDADE DE FILOSOFIA, LETRAS E CIÊNCIAS HUMANAS \\ DEPARTAMENTO DE LETRAS CLÁSSICAS E VERNÁCULAS \\ PROGRAMA DE PÓS-GRADUAÇÃO EM LETRAS
}

\title{
RAUL POMPÉIA: JORNALISMO E PROSA POÉTICA
}

REGINA LÚCIA DE ARAÚJO

São Paulo

2006 
UNIVERSIDADE DE SÃO PAULO

FACULDADE DE FILOSOFIA, LETRAS E CIÊNCIAS HUMANAS

DEPARTAMENTO DE LETRAS CLÁSSICAS E VERNÁCULAS

PROGRAMA DE PÓS-GRADUAÇÃO EM LETRAS

\title{
RAUL POMPÉIA: JORNALISMO E PROSA POÉTICA
}

\author{
REGINA LÚCIA DE ARAÚJO
}

Tese apresentada ao Programa de Pós-Graduação em Literatura Brasileira, do Departamento de Letras Clássicas e Vernáculas da Faculdade de Filosofia, Letras e Ciências Humanas da Universidade de São Paulo, como exigência para a obtenção do título de Doutor em Letras.

ORIENTADOR: PROF. DR. JOSÉ ALCIDES RIBEIRO

São Paulo

2006 


\section{DEDICATÓRIA}

Dedico esta pesquisa ao meu orientador Professor Dr. José Alcides Ribeiro, pela competência, dedicação e o apoio amigo com que me acompanhou. 


\section{AGRADECIMENTOS}

Agradeço à energia cósmica pelo cumprimento de mais esta tarefa e a todos que direta ou indiretamente contribuíram para seu sucesso, simbolizados por Uriel. 


\section{SUMÁRIO}

$\begin{array}{ll}\text { ÍNDICE DE FIGURAS } & 07\end{array}$

$\begin{array}{ll}\text { RESUMO } & 08\end{array}$

$\begin{array}{ll}\text { ABSTRACT } & 09\end{array}$

$\begin{array}{ll}\text { INTRODUÇÃO } & 10\end{array}$

1 RECEPÇÃO CRÍTICA E PERFIL LITERÁRIO DE POMPÉIA 35

$\begin{array}{ll}1.1 \text { Prosa Poética } & 59\end{array}$

2 JORNALISMO E LITERATURA / TEXTO-IMAGEM 88

3 JORNALISMO E PROSA POÉTICA: ANÁLISE DOS

TEXTOS DE A GAZETA DA TARDE 112

3.1 Baudelaire e Pompéia 113

3.2 Análise dos textos do periódico 133

4 CANÇÕES SEM METRO: INTRADIALOGISMO ENTRE CANÇÕES

DO LIVRO E DO PERIÓDICO A GAZETA DA TARDE $\quad 170$

$\begin{array}{ll}\text { CONCLUSÃO } & 189\end{array}$

REFERÊNCIAS 197

$\begin{array}{ll}\text { ANEXOS } & 205\end{array}$

Figura 1: Capa da Revista A Galeria Illustrada $\quad$ A1

Figura 2: Vinhetas da Revista A Galeria Illustrada A2

Figura 3: Canções sem Metro: Ramo da Esperança I

Revista A Galeria Illustrada, n. 4, 20 nov. 1888 A3

Figura 4: Canções sem Metro: As flores D’Alleluia II

Revista A Galeria Illustrada, n. 12, 30 nov. $1888 \quad$ A4

Figura 5: Canções sem Metro: A Morte de Rosita III

Revista A Galeria Illustrada, n. 19, 10 dez. 1888 A5

Figura 6: Canções sem Metro: As Violetas de Alina IV 
Revista A Galeria Illustrada, n. 28, 20 dez. 1888

Figura 7: Canções sem Metro: Para o Sul! V

Revista A Galeria Illustrada, n. 36, 30 dez. 1888

Figura 8: Canções sem Metro: A Bandeira Branca VI

Revista. A Galeria Illustrada, n. 44, 10 jan 1889

Figura 9: Canções sem Metro: Noutes Pretas VII

Revista A Galeria Illustrada, n. 51, 20 jan. 1889

Figura 10: Canções sem Metro: Manhãs Hellenas VIII

Revista A Galeria Illustrada, n. 61, 20 fev. 1889

Figura 11: Canções sem Metro: Victima do Incolor IX

Revista A Galeria Illustrada, n. 76, 30 mar. 1889

Figura 12: Canções sem Metro: Alma Espectro X

Revista A Galeria Illustrada, n. 84, 10 abr. 1889 


\section{LISTA DE FIGURAS}

Figura 1: Canções sem Metro: Alma Espectro X

Figura 2: Canções sem Metro: As flores D’Alleluia II

Figura 3: Texto inédito: Epiphania

Figura 4: Canções sem Metro: Rumor e Silêncio XXXV

Figura 5: Vulcão Morto XXXVIII

Figura 6: Os Continentes: XXXIX

Figura 7: Os Deuses: XL

Figura 8: Sic Transit: XLI

Figura 9: Solução: XLIII

Figura 10: Tormenta e Bonança: XLIV

Figura 11: Conclusão: XLV 


\section{RESUMO}

ARAÚJO, R. L. Raul Pompéia: jornalismo e prosa poética. Tese (Doutorado) - Faculdade de Filosofia, Letras e Ciências Humanas da USP, São Paulo, 2006.

O objetivo deste trabalho é comprovar a criação de um gênero híbrido e inovador - a prosa poética -, ligada ao jornalismo e à literatura do final do século XIX. Esta pesquisa analisa a prosa poética de Raul Pompéia, a partir de textos selecionados como corpus, publicados no periódico, A Gazeta da Tarde, de 21 a 29 jan. 1986. Paralelamente comparamos os textos equivalentes em sua versão de livro, publicados pela primeira vez em 1900, comentando também o conjunto das Canções sem metro.

Palavras-chave: prosa poética, jornalismo e literatura, símbolos metafísicos, cosmogonia 


\begin{abstract}
Araújo RL. Raul Pompéia: jornalismo e prosa poética [Raul Pompéia: journalism and poetic prose]. São Paulo (BR); 2006. [PhD Thesis - Faculdade de Filosofia, Letras e Ciências Humanas da Universidade de São Paulo Brazill].

The main objective of this work is to compare the creation of a hybrid and new genre - the poetic prose -, by Raul Pompéia, related to journalism and literature at the end of the XIX century. This research analyses the poetic prose written by Raul Pompéia, by selecting texts as its corpus, published in the periodic “A Gazeta da Tarde”, from January 21st to January 29th, 1986. At the same time we have compared the equivalent texts published on book for the first time in 1900, also discussing the other texts which form the whole group.
\end{abstract}

Key words: Poetic Prose, Journalism and Literature, Metaphysical Symbols, Cosmogony 


\section{INTRODUÇÃO}

Esta pesquisa tem como objetivo principal, a caracterização da poética de Raul Pompéia, a partir da análise e interpretação dos textos mais representativos da sua prosa poética os quais selecionamos da A Gazeta da Tarde. Os textos são: Rumor e Silêncio, XXXV; Vulcão Extinto, XXXVIII; Os Continentes, XXXIX; Os Deuses, XL; Sic Transit, XLI; Solução, XVIII; Tormenta e Bonança, XLIV; Conclusão, XLV.

Este trabalho contempla o campo transdisciplinar existente entre o jornalismo e a literatura brasileira, pela análise dos textos selecionados em A Gazeta da Tarde (1886) e sua forma equivalente em livro, a prosa poética de Raul Pompéia, em um processo de dialogismo interno ou intratextual, ou seja, o diálogo entre as versões de um mesmo texto. Também, incluí, em anexo, os textos de: A Galeria Ilustrada, como modelo do perfil da imprensa ficcional de uma revista da época, com o objetivo ainda de completar a nossa percepção, relativa à presença do visual na linguagem verbal do autor em estudo.

As pesquisas têm dedicado pouca atenção à prosa poética de Raul Pompéia, enquanto há inúmeros estudos centrados em sua obra mais conhecida, o seu romance, $O$ ateneu, considerado pela maioria a sua obra prima.

Ao definir sua prosa poética, como objeto desta pesquisa, fazemos alusão aos textos em prosa poética - Canções sem metro -, publicados em periódicos da época e, após sua morte, também compilados e publicados em livro, a partir de 1900, pelos contemporâneos do autor e posteriormente pelos estudiosos da poética do renomado escritor.

Há escassez de crítica sobre a prosa poética de Raul Pompéia e alguns críticos a abordaram sob um esboço panorâmico, tocando de maneira sutil alguns aspectos fundamentais de sua prosa poética. Daí, a necessidade de um aprofundamento dessas questões, a fim de buscar melhor compreender essa poética inovadora, trazendo a nossa contribuição, no sentido de entender também suas canções, uma vez que sua prosa tem sido bastante contemplada pela crítica literária. 
Há um denominador comum, consenso de toda a crítica: em sua busca obsessiva pela perfeição, apesar de sua curta existência, a poética de Raul Pompéia antecipou as mudanças que ocorreriam em movimentos literários em décadas depois. Assim, em meio a tantas e ótimas produções, destaca-se um poeta que veio, desde 1881, com seus primeiros textos, publicados em periódicos do século XIX, construir, segundo a crítica, um dos projetos mais originais e fecundos da poética brasileira de seu tempo que, devido às suas características, estarão sempre contextualizadas.

A estética das canções de Pompéia foi comentada pela crítica especializada da época, em pequenos ensaios, por ocasião da primeira compilação, recolhida dos periódicos da época, por seu amigo, João Andréa, a pedido da mãe do falecido autor. Naquela primeira edição, de Canções sem metro aparecem dois curtos ensaios críticos escritos por Rodrigo Otávio e Coelho Neto, especificamente. Eugênio Gomes, Venceslau Queirós, Lêdo Ivo, Afrânio Coutinho, Sonia Brayner, Leyla Perrone Moisés, Therezinha Bartholo, José Alcides Ribeiro, Heitor Martins, Lopes e Silva, entre outros da atualidade, também escreveram sobre a prosa poética de Raul Pompéia (1863-1895) que com sua poética inovadora antecipa características de movimentos literários posteriores, apesar de pertencer cronologicamente ao período Realismo/Naturalismo e sua poética apresentar traços simbolistas e impressionistas.

Todavia, o que muito motivou a escolha desse estudo foi o fato de estar ligado tanto ao jornalismo como à literatura. Selecionamos textos publicados inicialmente no periódico - A Gazeta da Tarde (1886) - e depois na forma de livro e percebemos o nível diferenciado do lirismo entre eles, além de outras modificações, conseqüência da enorme preocupação do autor que sempre burilava seus textos incansavelmente. Estudamos o dialogismo interno ou intratextual, nas versões equivalentes de um mesmo texto publicado na imprensa e posteriormente em livro.

Sabemos que a produção ficcional para publicação em periódicos constitui uma área deveras interessante, no tocante ao estudo da problemática da criação literária. Sobretudo, no século XIX, uma vez que, naquela época, o escritor era obrigado a realizar um trabalho ainda muito artesanal para uma posterior publicação em forma de livro. Além disso, devemos nos lembrar que a indústria cultural pode levar o escritor a produzir, de acordo com a demanda do 
mercado, apesar de as estatísticas comprovarem que muitas obras que se tornaram clássicas, devido ao seu alto valor literário, foram, primeiramente, publicadas em periódicos.

Esse fato se aplica ao caráter inovador e ao valor criativo dos poemas em prosa de Raul Pompéia, que apresentam um questionar cosmogônico. Reitero que cosmogonia nesta pesquisa tem o sentido de uma descrição hipotética da criação do mundo ou das transformações do cosmos, percebidas pela sensibilidade artística do autor.

Em se tratando de "Raul Pompéia: jornalismo e prosa poética”, título desta pesquisa, e, mais especificamente, do estudo das Canções sem metro, interessam-nos, particularmente, seus símbolos recorrentes, que constituem módulos paradigmáticos, presentes em seus textos e que formam a estrutura da maioria de suas composições em prosa poética.

Dentro da perspectiva de uma continuidade em progressão, acontece o dialogismo intertextual, Bakhtin (1997). Ele se origina do pensamento profundamente relacionado, consciente ou inconscientemente, com o contexto social e histórico do artista, com o conhecimento, a reflexão e a sensibilidade que esse desenvolve, acerca dos seus predecessores e dos que o sucederão.

Esse contexto, ou seja, as duas últimas décadas do século XIX assumem uma importância que não pode ser ignorada, quer no nível dos processos de gênese, de uma corrente de determinado pensamento, quer no nível da interpretação e compreensão, que hoje procuramos, acerca desses artistas da palavra e do seu pensamento criador. Devemos, ainda, nos ater ao fato de que os poemas em prosa de Raul Pompéia que foram publicados em periódicos, representantes da indústria cultural do século XIX, traziam a criação de uma forma inovadora - a prosa poética. E lembramos que o autor pode ter sido influenciado, em função de gênero, pela leitura de outros escritores, como o francês, Baudelaire, cuja poesia profética também pode ser identificada nos textos do escritor em estudo.

A biografia de Raul Pompéia mostra que o autor desenvolveu precocemente uma visão crítica da vida, em seu sentido psicológico e social, e da realidade nacional, em seus aspectos sócio-político-culturais. Esse escritor orientou-se por um realismo idealista e introspectivo que fez de seu romance - O Ateneu - uma das obras-primas da literatura brasileira e as suas 
Canções sem metro, a nosso ver, constituem um avanço na literatura nacional pela criação de um novo gênero híbrido, além da riqueza de seu conteúdo que traz a cosmovisão de Pompéia.

Raul d'Ávila Pompéia nasceu na localidade de Jacuecanga, em Angra dos Reis, RJ, em 12 de abril de 1863. Estudou no Colégio Pedro II, onde em 1880 se bacharelou em Letras. Publicou, nesse mesmo ano, o romance Uma tragédia no Amazonas e, a partir de 1881, participou da campanha abolicionista ao lado de Luís Gama. Iniciou o curso de direito em São Paulo, que concluiu em Recife, PE, em 1886. Ao voltar para o Rio de Janeiro, colaborou como crítico de arte, na Gazeta de Notícias, onde o romance, O Ateneu, apareceu seriado em 1888. Revoltado, mas inteligente e atento aos acontecimentos, forjou sua expressão literária na participação direta no cotidiano, cujos conflitos e angústias pôde expressar nas páginas de $O$ Ateneu. Autobiográfico, o livro mostra o jovem autor como personalidade sensível, mas desajustada ao meio ambiente e aos valores de uma educação deformadora, que se transformou em crítico impiedoso do que viveu e viu na adolescência passada no colégio interno. Caricaturista mais ferino com a palavra do que com o desenho, Raul Pompéia criou, em $O$ Ateneu, alguns tipos expressivos, como o diretor Aristarco, que seria uma caricatura cruel do barão de Macaúbas, o conselheiro Tietch, o professor Venâncio, Ribas, Nearco e Sanches, o primeiro aluno da turma.

A nenhum desses personagens, porém deu a dimensão existencial de Sérgio, sofrida encarnação de si mesmo, que mantém um ambíguo relacionamento com Bento Alves, o colega ao qual ele denomina "forte e valente", e se esquiva como pode às armadilhas da educação repressiva. Mas o importante, no caso, não é o internato como prisão, como viveiro de ansiedades e desencantos, de aflições e inquietudes. Relevante é o itinerário psicológico dos personagens, num dia-a-dia repleto de amargor e frustrações, em que toda a projeção ressentida do escritor se revela. Alguns críticos, a exemplo de Mário de Andrade, chegaram mesmo a acusá-lo, por seu tom agressivo e sua intenção demolidora, de ter sido dominado pelo exagero e ódio.

No entanto, o melhor de seu talento expressou-se justamente na autenticidade de seu temperamento passional. Em 1890, foi nomeado professor de mitologia na Escola de BelasArtes, e no ano seguinte quase se bateu em duelo com o poeta Olavo Bilac. Caricaturista e orador de comícios, Pompéia demonstrou pela política um interesse crescente: apoiou o 
nacionalismo de Floriano Peixoto e, para hostilizar os ingleses e portugueses, desenhou, em 1893, a charge "O Brasil crucificado entre dois ladrões". Como diretor da Biblioteca Nacional, em 1894, foi demitido um ano depois, acusado de desacato ao presidente da república. Impelido ao suicídio pela incompreensão dos amigos, o isolamento e a crescente tensão emocional, Raul Pompéia morreu no Rio de Janeiro, em 25 de dezembro de 1895.

Como já foi dito, esta pesquisa tem com o objetivo principal, o estudo da poética de Raul Pompéia, a partir da análise dos textos mais representativos, que selecionamos de periódicos da sua época, A Gazeta da Tarde. Os textos são: Rumor e Silêncio, XXXV; Vulcão Extinto, XXXVIII; Os Continentes, XXXIX; Os Deuses, XL; Sic Transit, XLI; Solução, XVIII; Tormenta e Bonança, XLIV; Conclusão, XLV. Posteriormente, incluímos um texto inédito intitulado Epifania.

O jornal A Gazeta da Tarde foi fundado em 1880 e dirigido por Ferreira de Meneses.Um exemplar característico de A Gazeta da Tarde possuía quatro páginas com textos relacionados a gêneros jornalísticos informativos e literários, bastante diversificados. Geralmente, cada página era organizada em cinco colunas separadas por filetes de cor preta. Os textos de caráter informativo apareciam em todas as páginas. Na primeira e na segunda página eram inseridas várias seções, por exemplo, Variedades, Notícias, Fatos diversos, Uma seção, Interior, Exterior, e/ou Solicitadas. Essa divisão apresentava-se semelhante à de outros jornais àquela época e consultados durante a pesquisa.

A seção variedades funcionava como uma espécie de micro-enciclopédia, trazendo textos variados de gêneros diferentes e sobre temas diversificados que pudessem atender ao gosto do leitor digestivo: ficção, relatórios científicos, ensaios políticos, verbetes sobre curiosidades científicas ou inéditas. Uma seção trazia crônicas e textos ficcionais variados, romances europeus traduzidos ou brasileiros, poemas e publicou as canções de Pompéia e estava sempre na primeira ou segunda página da gazeta. As Correspondências, Publicações a Pedido, Avisos, Solicitações, Leilões e Anúncios vinham nas duas páginas derradeiras. É importante ressaltar que Pompéia criou o novo gênero, a sua prosa poética, no ambiente de jornal, conforme comprovamos no capítulo de análise. 
O livro Canções sem metro reúne a trajetória da prosa poética de Raul Pompéia, cujos textos haviam sido publicados esparsamente nos periódicos. Compõe-se de cinco partes, todas intituladas, conforme destacamos a seguir. A primeira, - Vibrações -, que ele inicia com uma epígrafe de Baudelaire. Os sentimentos são representados, simbolicamente pelas cores e percebe-se a pintura no cenário. A segunda parte chama-se - Amar - e, através das estações, o eu lírico demonstra poder de análise psicológica, digressões de cunho poético, aliadas a certa preocupação metafísica, ao questionamento cosmogônico. A terceira parte é o - Ventre -, composto de temas tais como o mar, a floresta, os animais, os minerais, a indústria, o comércio e a noite. Percebe-se aqui, a influência de Baudelaire e Põe, muita habilidade estilística, em meio ao pessimismo, às emoções fortes, ao espanto, à morbidez, às alucinações e ao magnetismo. A quarta unidade é intitulada - Vaidades. O eu poético remete-se, dialogicamente, à bíblia - Eclesiastes. Ante o mundo caótico, a arte apresenta-se como a salvação possível para a inteligência superior. Os símbolos são: Mefistófeles, representando a descrença, o pessimismo. E Hamlet, como corporificação da dúvida, tormento perpétuo do ser humano. A arte constitui o único refúgio. A última parte fala do - Infinito -, espaço e tempo e oito de seus textos constituem objeto de nossa análise, pois julgamos que eles constituem um corpus bastante representativo do objetivo a que nos propomos neste estudo.

A diversidade e a riqueza da prosa poética de Raul Pompéia abrem perspectiva para uma gama de abordagens diversificadas. A crítica atual pouco tem investido nesta abrangência, a fim de buscar compreender e explicar as características que a distinguem. Algumas críticas são consoantes a uma produção da época, ou seja, própria da sensibilidade artística e do caráter conflituoso do autor. Outras sugerem que sua obra prima, O Ateneu, teria eclipsado o restante de sua produção literária.

Araripe Júnior, cuja fortuna crítica reúne a crítica publicada em periódicos de 1888 e 1889, sobre o gênio criador de Pompéia, assim como Nestor Vítor, falecido em 1932, mas grande crítico e seus textos esparsos foram reunidos e publicados em três volumes, pela Casa Rui Barbosa, em 1969; no primeiro volume há páginas escritas por Nestor Vítor e dedicadas a Raul Pompéia. A importância dessa crítica é que ela foi publicada em periódicos e mostra a recepção crítica da obra de Pompéia naquela época. 
A crítica de Venceslau Queirós, publicada em 27 de junho de 1901 consta da obra Canções sem metro, 1982, p. 30. Apesar de apresentar caráter mais informativo que analítico, próprio da época, o autor mescla elementos biográficos com crítica temática ao valorizar características estilísticas desconsideradas pela crítica historicista e impressionista. Ele fala do nirvanismo e pessimismo próprios da obra de Pompéia e aponta as influências recebidas pelo autor direta e indiretamente: Poe, Baudelaire, Bertrand, filiando as Canções sem metro ao então recente gênero dos poemas em prosa. Mikhail Bakhtin, em relação aos conceitos de gêneros do discurso e de dialogismo.

Lêdo Ivo (1963) foi um dos primeiros críticos a estudar com seriedade a prosa poética de Pompéia e também a perceber a sua relevância. Ele discorda dos críticos que incompreenderam o seu valor, como Muricy (1973) que não reconhece seu caráter simbolista nem lhe atribui valor literário e outras opiniões, a exemplo de Gomes (1958) que afirma que os poemas em prosa de Pompéia são marcados pelo impressionismo e pela escritura artística, mas que não coadunam com o temperamento do autor que deveria expressar-se melhor em uma linguagem mais impulsiva e vibrante, como em seu romance O Ateneu. Lúcia Miguel Pereira (1950) rejeita a influência da escola naturalista em Pompéia. Coutinho (1982) considera o estilo de Pompéia nas canções um pouco confuso. Bosi (1974, p. 205), rotula a prosa poética de Pompéia como um ensaio estetizante, com qualidade inferior a $O$ Ateneu, mas válido em termos de seu esforço extremo no cuidado com o traço das formas. Moisés (1984) aponta a influência de Aloysius Bertrand e de seu Gaspard de la Nuit (1842), assim como de Baudelaire e seus Petits poèmes em prose (1869), mas questiona a poeticidade em algumas das canções. Melquior (1996), sem explicar a razão, afirma que a prosa poética das Canções sem metro está próxima do decorativismo parnasiano.

Vários críticos têm apresentado as afinidades entre Pompéia e Baudelaire. Venceslau de Queirós (apud Raul Pompéia, 1982), Brayner (1979), Ramos (1957), Ivo (1963) citam como elementos de afinidade entre os dois poetas: a opção pelo desenvolvimento do poema em prosa, pelo uso freqüente das analogias, o pessimismo, as correspondências, o nirvanismo, demonstrando a influência de Baudelaire na poética de Pompéia.A temática da destruição dos ideais e a sua dramatização na linguagem são também aspectos comuns aos dois escritores. 
Ivo (1963) estudou as canções e seu estudo contribui muito para a sua compreensão. Ele fala sobre a influência indiscutível de Baudelaire em Pompéia, percebe o pessimismo e o nirvanismo em sua temática. Aponta a teoria de Swedenborg e a cosmovisão romântica de Vitor Hugo, como fonte de influência da visão simbólica e mística do universo nas canções que em sua opinião constituem uma "viagem imprecatória através do tempo e do espaço, marcadas por uma singular consciência histórica e social, além de um claro sentido evolucionista” (IVO, p. 83). Ivo percebe o chamado lado “visionário” de Pompéia, segundo Lopes e Silva (2005).

Afrânio Coutinho, escritor, crítico e teórico e historiador da Literatura que teve o mérito de reunir toda a obra de Pompéia, em dez volumes. Ele chama a atenção da crítica para o esquecimento das Canções sem metro que deu relevância apenas a $O$ Ateneu, afirmando que as canções são de grande valor literário e têm importância devido ao fato de terem contribuído para “a renovação da literatura brasileira, tal como ocorreu na França, onde a poesia recebeu desse gênero híbrido um saudável e definitivo impulso modernizador” (POMPÉIA, 1982, p.22). de Acordo como o crítico, o impressionismo pode ser percebido nas técnicas de apresentação da linguagem de Pompéia, na estrutura dos textos que prioriza o tempo psicológico ou mítico, no relevo que as cores apresentam acompanhando as sensações visuais exploradas pelo escritor e na escritura artística, a exemplo dos irmãos Goncourt, conforme salienta Coutinho (1966, p. 228). O crítico acrescenta que depois de formar o espírito na doutrina do naturalismo, recebeu influência da estética simbolista, mas só encontrou plena e satisfatória expressão nos cânones do impressionismo.

Elói Pontes, que publicou sua biografia em 1935, na tentativa de resgatar a história daquele temperamento, publicando, inclusive, textos em estilo confessional e frases pronunciadas por Pompéia, algumas das quais usamos como epígrafes dos capítulos desta pesquisa. Camil Capaz, cuja obra foi editada em 2001, é também biógrafo de Pompéia e reconstitui sua história literária por meio da pesquisa em jornais da época e outros documentos deixados pelo autor.

Leyla Perrone-Moisés que organizou textos de vários autores sob o nome O Ateneu: retórica e paixão, por ocasião do centenário de sua publicação (1888-1988); Sonia Brayner (Labirinto do espaço romanesco), livro em que tece importantes observações sobre as Canções sem metro e Therezinha Bartholo, autora de vários artigos sobre a obra de Pompéia e 
responsável pela publicação da edição revisada pelo autor de $O$ Ateneu, ambas pesquisadoras e críticas contemporâneas da obra de Pompéia, Hugo Friedrich, teórico básico para pesquisa sobre a lírica, e também estudioso de Baudelaire.

Maria Luisa Ramos (1957), que fez uma análise psicológica de O Ateneu, conclui a existência de uma sub-estrutura masoquista na personalidade do escritor e passa a interpretar o homem e a obra baseada no modelo utilizado, reduzindo ambos a expressões inconscientes de um temperamento a que ela denomina doentio. Assim a lutas republicana e abolicionista de Pompéia têm uma dimensão ideológica subordinada à expressão de seus conflitos psicológicos. Também as escolhas estilísticas, temáticas e ideológicas são explicadas com base na personalidade do autor. O uso da repetição no estilo e nos temas, a seu ver, em O ateneu, devem-se ao seu caráter neurótico. Todavia, ao tratar das Canções sem metro, a autora restringe-se a uma análise estilística, não buscando compreender os poemas à luz da poesia. Na introdução de seu estudo ela considera que a obra constitui expressão da personalidade de Pompéia e não menciona a influência que ele teria tido de Baudelaire.

Nelson Werneck Sodré e Gilberto Freyre, informações históricas sobre a literatura e a imprensa no Brasil, contidas no segundo capítulo.

José Alcides Ribeiro, escritor e pesquisador sobre a imprensa e ficção do século XIX, autor dos artigos: Texto verbal e imagem visual em O Aateneu, Estudos, v.28, n.3, p. 366 499, mai. Jun. 2001 e de O perfil literário e jornalístico no Correio Mercantil (2005), nos quais nos embasamos para a análise dos textos. Heitor Martins (1990) e Lopes e Silva (2005) pesquisadores mais recentes sobre a poética de Pompéia.

Segundo Lopes e Silva (2004), ao recompor as três fases da história da humanidade nas Canções sem metro, para o primeiro período, Pompéia aponta as cruzadas como o momento mais grave e a figura de Hércules como exemplo do ideal de bondade, pois representa "a bondade heróica e mitológica” Para o segundo período, ele aponta as guerras religiosas e a reforma luterana como os momentos críticos e a figura de Cristo como modelo, pois representa “a bondade medieval e católica”. Por fim, aponta a revolução francesa como o terceiro momento crítico e a figura de D. Quixote como símbolo mítico da "bondade moderna idealizada na ironia do livre exame”. Embora de maneira diferente, os três heróis pecam pelo 
mesmo erro: o anacronismo e a ingenuidade. Pois, movidos pelo coração, pela bondade que os retira da "existência real”, mas os torna radicais ao extremo pelo idealismo da corrigenda e do aperfeiçoamento (1981, p. 211), os três se tornam vítimas dos sonhos em conflito com a realidade. A cada novo ciclo, eles se tornam mais fracos e os ideais vão sendo abandonados, passando-se da resignação cristã à ironia moderna representada pelo cavaleiro de Cervantes.

Martins (1990) defende a teoria de que Pompéia integra o projeto literário brasileiro que se inicia com os neoclássicos, atravessando a experiência romântica e o período do realismo burguês, apresentando certas características básicas do movimento literário: a tradição portuguesa, sobretudo, em se tratando de uma língua nacional, com raízes coloniais, a inclusão das minorias culturais, como a africana e a indígena, participantes e complacentes com o domínio da tradição portuguesa. Ainda, a consciência de que a realização desse projeto se concretiza em solo americano, com a criação de uma literatura que apresente o instinto de nacionalidade a que Machado de Assis se referia. O chamado espírito de modernidade, tanto em nível ideológico, como estético que se sobressai desde o romantismo, não invalida esse projeto literário, mas afirma a necessidade de progredir, avançar, desenvolver-se, transformar, mesmo porque e impossível cortar as influências de estilos anteriores.

Nossa intenção é comprovar a criação de um novo gênero, a prosa poética, no Brasil, implementada por Pompéia, sob a influência do ato de escrever para jornal e para livro. Fez-se necessário o estudo do conjunto de textos da obra, uma vez que nossa intenção é caracterizar a linguagem de Pompéia em termos de gênero e de estilo. A organicidade das Canções sem metro, publicadas primeiro em jornal e depois em livro constitui um mito cosmogônico em que o eu poético questiona a origem e a transformação do mundo que ele percebe. É importante ressaltar que ele criou esse gênero inovador, dentro do ambiente do jornal.

Portanto, como hipótese neste trabalho, estudamos as canções de Pompéia para demonstrarmos as marcas da criação de um novo gênero híbrido, no Brasil, buscando as contribuições dessa temática, em sua construção lírica, e enfocando especialmente as variantes na composição de sua prosa-poética, como produção ligada ao jornalismo e à literatura.

Em seus textos diversos, sob a forma de prosa-poética, percebemos a influência do jornalismo na literatura, com conotações de crônicas dos periódicos da época. A crítica 
enfatiza ser uma poesia que se estrutura a partir de uma tensão entre o mundo exterior (imagens visuais) e o interior (imagens metafísicas), com questionamento intimista e talvez este fato possa ser percebido nas inúmeras antíteses que fazem parte de sua técnica composicional. Os textos do corpus são: Rumor e Silêncio, XXXV; Vulcão Extinto, XXXVIII; Os Continentes, XXXIX; Os Deuses, XL; Sic Transit, XLI; Solução, XVIII; Tormenta e Bonança, XLIV; Conclusão, XLV e cada um tem seu equivalente na publicação em livro, além do texto inédito - Epifania -, conforme mencionamos anteriormente.

Em decorrência do estudo, apontaremos primeiramente os traços de gênero, os seus aspectos recorrentes, retomados da tradição européia desenvolvida por Baudelaire, na França. Em segundo lugar, uma análise de sua poética e do seu estilo, a fim de reconhecer os recursos poéticos ou antipoéticos utilizados pelo autor. Esclarecemos que a análise estará embasada, sobretudo, na teoria de gênero de Morier (1981), de estilo de Da Cal (1969), além de Vivaldi (1979) para as questões referentes à linguagem jornalística.

Por fim, este estudo também envolverá a busca de compreensão de sua linguagem poética em um contexto político-social determinado. Sua origem inovadora, como modelo de prosa-poética, o percurso trilhado, a partir das primeiras publicações nos periódicos e as características literárias que o singularizam.

Lembremos, ainda, que sua produção ficcional destinava-se, sobretudo, à publicação na imprensa periódica do século XIX. O sentimento cosmogônico aparece na seleção vocabular, nas combinações sintagmáticas ou paradigmáticas, nos símbolos, relacionando um texto à sua versão burilada equivalente, sobretudo, devido ao seu perene questionar sobre a criação do cosmos e a efemeridade de suas transformações, que, de acordo com o eu poético, ás vezes podem levar à nulidade final. Pode-se pensar, equivocadamente, que as estruturas simbólicas sejam meras convenções utilizadas para descrever a realidade. Isso só seria válido na medida em que se aplicasse igualmente a qualquer manifestação, que é sempre uma determinação, uma fixação, começando pela linguagem, pelo verbo. Porém, é óbvio que não há maneira de apreender a realidade, senão, por meio do símbolo, seja este lingüístico, numérico, estilístico ou dos códigos que este forma. O símbolo não é arbitrário, e reflete autenticamente o que expressa, requisito sem o qual seria impossível qualquer relação ou comunicação. Deve-se ter 
em mente que, por tomar uma forma, constitui uma estrutura na torrente do não-enunciado, na existência a ser revelada pelo leitor.

Desde a antiguidade se conhecia esta verdade. Daí, o valor criativo que atribuíam à palavra. Ou seja: o sujeito participa de qualquer fato objetivo e, portanto, o gera; a história de seus ciclos também testemunha esta inter-relação constante. No entanto, a irrealidade do mundo e do homem só pode ser observada porque existe e deve ser sujeito e objeto de alguma revelação. Os símbolos, os conceitos ou os seres são imprescindíveis no plano do universo, assim como na literatura. Segundo Lotman (1990, p. 103) o símbolo existe antes mesmo de qualquer tipo de texto e independente dele. Ele está mergulhado na memória de um escritor desde as mais recônditas memórias e aflora em determinado texto recém criado como um pingo de óleo fresco. Portanto, alguns códigos como o lingüístico, o poético, o aritmético ou o geométrico, entre outros, não são convenções casuais, mas expressam realidades arquetípicas e formam a base de qualquer estrutura, não só na concepção exterior, mas também na interior. A ponto de se poder afirmar que essas imagens constituem categorias próprias do pensamento, fazendo do homem, sobretudo, do poeta, um autêntico intermediário entre o conhecido e o desconhecido, ou seja: o maior dos símbolos, capaz de unificar, por sua mediação, a poética da composição. E tudo isso pode ser percebido nas Canções sem metro de Pompéia.

Para Bakhtin (1997) gênero está relacionado ao movimento. Embora os gêneros representem os modos de organização mais estáveis, certos enunciados ou formas padrão dentro de determinado contexto de comunicação -, ou seja, todo gênero está em constante transformação, em virtude das possibilidades de dialogismo ou contaminação dos próprios gêneros entre si. O gênero é novo e velho ao mesmo tempo, os seja, renasce e se renova a cada manifestação individual, segundo aquele teórico. Todo gênero surge de outros gêneros, como diz Todorov, cada gênero é o resultado de uma contínua regeneração. Esse conceito é de fundamental importância nesta pesquisa pelo fato de enfocar o estudo de uma forma híbrida. Bahktin (1997, p. 284) ainda ressalta que os gêneros literários têm sido estudados apenas pelo ângulo artístico-literário de sua especificidade e não como tipos particulares de enunciados que se diferenciam de outros tipos congêneres. Afirma que nos gêneros literários o estilo individual faz parte do empreendimento enunciativo enquanto tal e constitui uma de suas diretrizes. 
Henri Morier, em cujo estudo sobre prosa poética subsidiamos a análise dos textos, embasando-nos em seu conceito de prosa poética. Segundo Morier (1981), em torno de 1840, a idéia do poema em prosa estava no ar, ou melhor, ela se desenvolvia como um novo estilo na literatura e em movimento contínuo. O romantismo encontrou nesse gênero misto um meio de expressão de acordo com suas tendências, porque o romantismo e o poema em prosa têm em comum: o gosto pela harmonia, pela mistura de gêneros, pela variedade, pelo movimento e o gosto pela liberdade e pelo idealismo.

Morier (1981) fala das várias manifestações do poema em prosa. A mais antiga seria a prosa cadenciada, usada nas ladainhas religiosas. Nesta forma Marmontel escreveu Les Incas, (1777), com 661 páginas, divididas em dois volumes. Depois, uma outra modalidade de prosa poética, repleta de exclamações iniciais, com entonações oníricas e tom bem musical, composta por Rosseau, entre outros. Essa manifestação constitui-se de prosa poética cadenciada junto a um sentimento ou ao estado de alma, ao sonho, à impressão difusa e ao abandono do ser às forças da natureza (p. 939). A seguir aparece o grande poema em prosa, difundido por Marmontel, citado anteriormente, Chateaubriand (Les martyrs) e Fénélon que deve ter lançado essa modalidade compondo Le Télémaque, romance idealizado, com heróis da mitologia no reino da Utopia, exibindo paisagem edênica, poema épico e lírico ao mesmo tempo, cheio de pompa e grandiloqüência. Guérin faz uso de vozes paralelas e suas composições apresentam estribilho, aliterações, assonâncias, cadência métrica monótona, clichês, interrogações oratórias, exclamações frias, invocações, sinônimos de estilo e prosopopéias. Na análise dos textos, veremos que as canções de Pompéia apresentam muitas dessas características. Então, a prosa poética se separa do estilo nobre e o lirismo alia-se ao tom satírico, sendo menos fatigante.

Com Lamennais surge uma forma intermediária, situada a meio caminho entre a prosa poética e o pequeno poema em prosa ritmada. Há ainda manifestações de prosa cadenciada corrente, na segunda metade do século XIX e também prosa rimada de Bruneau e elas têm em comum o movimento ambicionado por Baudelaire. Na análise das Canções sem metro, de Pompéia, perceberemos características variadas de todas essas modalidades em sua escritura artística criada no ambiente de jornal. 
Aguiar e Silva (1990) fala da diferença entre modo e gênero literário. Os modos literários constituem categorias meta-históricas e os gêneros, categorias históricas. A literatura não obedece a normas fixas nem a esquemas estruturais rígidos e parte da possibilidade de uma frase poder significar múltiplas coisas e de todos os sentidos possíveis poderem ser sujeitos a uma processo de leitura interpretativa. O sentido apreendido pela competência literária pode ser aberto, instável ou indeterminado, não sendo a sua natureza que calcula o nível de competência do leitor.

O que acontece é exatamente o contrário: é a competência do leitor que pode perceber todas as possibilidades de sentido de um texto literário, sem se pretender estabelecer uma norma geral. Assim, uma frase pode ter sempre o mesmo sentido para vários lingüistas, mas o mesmo texto não terá certamente o mesmo sentido para todos os leitores críticos.

A competência literária exercida como uma competência poética observa apenas o texto literário em termos de performance lingüística, que obedece a um código pré-determinado. Como a literatura envolverá sempre um elevado grau de incerteza sobre o sentido verdadeiro de um texto, não é possível estabelecer de forma tão simplista esta analogia entre a competência literária e uma competência poética.

Os estudos literários pós-estruturalistas têm privilegiado, por isso, não a poética, mas uma nova forma de hermenêutica como modo operativo mais próximo do desejo do leitor moderno: a competência literária não nos mostra o modo de funcionamento de um texto literário, mas antes possibilita descobrir em determinado texto o que se aproxima do nosso mundo cotidiano. Portanto, a competência literária, serve de instrumento que nos permite encontrar num texto literário não só os reflexos da nossa própria experiência individual, mas também os traços que nos identificam culturalmente. De qualquer modo, a competência literária implica colocar o trabalho literário na dependência do seu leitor-receptor.

Propostas teóricas como a estética da recepção ou a teoria do efeito têm procurado demonstrar que o sentido de um texto resulta unicamente da experiência ou, da competência do leitor. Todavia, é justo lembrar que o conceito também permite falar de uma competência literária do autor, ou seja, a sua arte, o seu trabalho de burilamento, o seu gênio criador, a sua inspiração e imaginação ou o seu estilo, dentre outros fatores. 
Iuri Lotman, de onde retiramos conceitos sobre o texto artístico e a importância do símbolo. Os símbolos, os conceitos ou os seres são imprescindíveis no plano do universo, assim como na literatura. Segundo Lotmann (1990, p. 103) o símbolo existe antes mesmo de qualquer tipo de texto e independente dele. Ele está mergulhado na memória de um escritor desde as mais recônditas memórias e aflora em determinado texto recém criado como um pingo de óleo fresco.Portanto, alguns códigos como o lingüístico, o poético, o aritmético ou o geométrico, entre outros, não são convenções casuais, mas expressam realidades arquetípicas e formam a base de qualquer estrutura, não só na concepção exterior, mas também na interior. A ponto de se poder afirmar que essas imagens constituem categorias próprias do pensamento, fazendo do homem, sobretudo, do poeta, um autêntico intermediário entre o conhecido e o desconhecido, ou seja: o maior dos símbolos, capaz de unificar, por sua mediação, a poética da composição. E tudo isso pode ser percebido nas canções sem metro de Pompéia.

Apesar de podermos constatar a importância dessa forma inovadora, à sua época, e sua repercussão na literatura brasileira, Raul Pompéia foi seu primeiro cultor e aquele que lhe imprimiu o cunho de excelência artística. Sua contribuição será assimilada, por escritores posteriores, como, Drummond, Jorge de Lima, Mário Quintana, Ledo Ivo, Paulo Mendes Campos, Ferreira Gullar, entre outros. Há um retorno à poética simbolista e um avanço na forma de vanguarda que será depois delineada pelos modernistas aludidos anteriormente, mas este fato não será objeto desta pesquisa.

Nas Canções sem metro há uma recorrência às imagens impressionistas, aos símbolos ligados ao sentimento cosmogônico. A seleção vocabular e a forma dos seus poemas em prosa aparecem reformuladas, em diferentes edições, o que gira em torno de um componente biográfico importante: a poesia para Raul Pompéia foi um exercício de disciplina, em que o autor perseguia obsessivamente a perfeição. Este fato explica as várias formas trabalhadas de um mesmo texto e publicadas em épocas e periódicos diferentes.

Como podemos notar, uma das características mais incisivas de sua prosa poética é a sua percepção de mundo, por meio de símbolos metafísicos e visuais, e o seu constante questionamento relativo à criação do cosmos. Durante a análise dos textos percebemos que as imagens e os símbolos têm papel fundamental na linguagem de Pompéia. Muitas vezes imagem e símbolo mergulham imperceptivelmente um no outro, sendo difícil distingui-los entre si. 
Esse fato é inusitado por tratar-se de produção ligada à imprensa, quando o autor muitas vezes direciona seu trabalho, visando apenas à demanda do mercado. Observamos nesse movimento uma mudança de perspectiva, uma expressão realista, mas ligada, tanto ao simbolismo-impressionista, quanto às características inovadoras de movimentos literários posteriores, o que pode ser objeto de nova pesquisa.

Percebemos nesse movimento que há um investimento maior na construção de uma poética inovadora do que no texto isolado. Esse diálogo se estende de maneira atemporal, ora em dialogismo com tendências que o antecedem, ora com características poéticas inovadoras. Raul Pompéia, apesar de objetivar outro tipo de publicação posterior, escreveu toda essa seleção de poemas em prosa para ser publicada em periódicos e, portanto, os textos se enquadram no jornalismo literário.

A compreensão dessa poética implica o desvendar da complexidade na imbricação dos gêneros, prosa e poesia, rica de imagens visuais e metafísicas, com nuances impressionistas e simbolistas, que viaja do realismo/naturalismo para a modernidade, provando que a literatura sempre antecipa da história.

Devemos atentar, ainda, para o fato de as canções de Pompéia falarem simbolicamente de um mito do final do mundo, implicando implicitamente a recriação de um novo universo. Essa temática mítica tem sido expressa desde os tempos arcaicos e repetem a idéia da degradação progressiva do cosmo que requer a sua destruição e recriação periódica. Eliade ( 1986) afirma que desses mitos de uma catástrofe final, que será ao mesmo tempo o sinal anunciador da iminente recriação do mundo, é que surgiram e se desenvolveram os movimentos proféticos e milenaristas das sociedades primitivas contemporâneas.

Diante do exposto, acrescentamos que a intenção deste trabalho é desenvolver um estudo que aprofunde as questões suscitadas pela crítica anterior e contemporânea sobre essa poética. O estudo está centrado nos textos compilados sob o nome de - Canções sem metro. Demonstraremos, por meio de um mapeamento dos textos e sua trajetória, a poética de Raul Pompéia, relacionada ao jornalismo e à literatura e, em decorrência, vamos comentar as diferenças entre a versão jornalística e aquela burilada para a publicação em forma de livro. Assim, observaremos as semelhanças e os contrastes, no processo de redação do texto, 
verificando as diferenças entre cada versão publicada nos periódicos e a sua forma equivalente publicada em livro, dentro do processo do dialogismo intratextual, aludido anteriormente.

Alguns estudos importantes foram realizados para dar fundamentação teórica ao trabalho. De início temos os teóricos: Vítor Manuel e Silva, como teórico da literatura que resume postulados de todas as correntes, de quem usamos os conceitos de poética, como estudo lingüístico dessa mesma função poética, aqui, no contexto da prosa poética de Pompéia; literariedade, como o conjunto de condições próprias da uma estrutura estéticoverbal; retórica, como disciplina lingüística que engloba o estudo dos processos de linguagem que caracterizam o discurso literário. Estilística, como o estudo que prioriza o modo peculiar como cada obra apresenta a sua linguagem estético-verbal. Interdisciplinaridade, como a soma de saberes diversos para a compreensão ou abordagem de determinado campo. Aguiar e Silva (1990) fala da diferença entre modo e gênero literário. Os modos literários constituem categorias meta-históricas e os gêneros, categorias históricas. A literatura não obedece a normas fixas nem a esquemas estruturais rígidos e parte da possibilidade de uma frase poder significar múltiplas coisas e de todos os sentidos possíveis poderem ser sujeitos a uma processo de leitura interpretativa. O sentido apreendido pela competência literária pode ser aberto, instável ou indeterminado, não sendo a sua natureza que calcula o nível de competência do leitor.

O que acontece é exatamente o contrário: é a competência do leitor que pode perceber todas as possibilidades de sentido de um texto literário, sem se pretender estabelecer uma norma geral. Assim, uma frase pode ter sempre o mesmo sentido para vários lingüistas, mas o mesmo texto não terá certamente o mesmo sentido para todos os leitores críticos.

Nesta visão trágica da História, visto que a sua essência reside na contradição irreconciliável (LESKY, 1976) entre o ideal e a sua negação pela realidade, a hamartia resulta da hybris que caracteriza a natureza humana. A desmedida humana surge em decorrência de os seres humanos terem se apossado, após a criação, de todas as qualidades, boas e más, que se encontravam espalhadas entre as diversas espécies animais, o que os transformou em espécie de monstros, conforme se percebe no poema "Os animais" (1982, p. 66), em Canções sem metro. Nele, assim como em "Os minerais", o autor propõe um diálogo com a Bíblia, por meio de epígrafes que foram retiradas da parte bíblica, "Gêneses" (I, 16 e I, 28). 
Ernesto Guerra da Cal (1969), crítico da obra de Eça de Queirós, entre outros, em cujo modelo de abordagem também nos subsidiamos para a análise dos textos relacionados ao corpus, dentro da linha que direciona esta pesquisa interdisciplinar. Da Cal consagrou-se nos EUA pelo seu trabalho universitário extremamente rigoroso e criador. Ele é poeta e crítico literário, conseguiu articular o seu aparelho analítico, transpôs os próprios limites e elaborou, à luz do texto eciano, uma rica e matizada teoria da narrativa.

Da Cal (1969) chama a atenção para a estrutura da frase na poetização da prosa, dizendo da tendência para as formas regulares, que indicam uma intenção de conseguir cadências métricas e estróficas, apesar de o texto não se apresentar em versos. As simetrias, os paralelismos, as enumerações produzem certa sonoridade compassada e regular, aumentando o grau da atmosfera poética. A melodia, o ritmo, a homofonia e as medidas silábicas da frase e do período atuam como elementos de ressonância lírica. Muitas vezes, ao analisarmos as canções de Pompéia, percebemos recursos poéticos que asseguram a cumplicidade dos sentidos do leitor para conseguir levá-lo ao clima de sua criação, ao movimento lírico no qual nasce a idéia em seu espírito, conforme modelo apresentado por Da Cal. O crítico ainda sugere que dentre todos os processos, o mais imediatamente perceptível é o que se baseia nos efeitos da harmonia imitativa, resultantes da combinação de sons das palavras ao seu conteúdo representativo. Essa combinação pode se dirigir no sentido de reforçar auditivamente a evocação da coisa mencionada, a fim de provocar associações que a sugiram por via sensorial, ou, simplesmente, criar maior valor expressivo ao conteúdo representativo das palavras, por meio de obscuras relações que em nossa vida psicológica ligam o som destas ao seu significado, ou seja, às excitações emocionais que tal significado produz. Tudo isso pode ser percebido pelo uso da aliteração, da repetição de vocábulos ou da repetição anafórica, recursos muito usados por Pompéia, em suas canções. E, ainda, segundo Da Cal, o estilo torna-se o elo que liga as idéias de um escritor à linguagem que ele usa para exprimir, acrescentando que um autor só desenvolve ou cria um estilo, quando tem uma visão de mundo junto à capacidade de exprimi-la.

E, pelo fato de esta pesquisa estar ligada ao jornalismo e à literatura, buscamos, também, subsídios teóricos em Vivaldi (1979), para quem o periodismo é algo muito mais que a técnica, as fórmulas, o trabalho e a habilidade. Constitui também arte e inspiração, assim como 
conhecimento de mundo e dos homens, por meio da psicologia e da filosofia aliadas a uma cultura sólida. Em se tratando de jornalismo, a primeira característica encontrada nas canções de Pompéia é a questão do nível narrativo, devido ao caráter híbrido do gênero. Percebemos também qualidades estilísticas necessárias ao jornalismo como, a densidade, a exatidão, a precisão, a sensatez, a naturalidade, o ritmo, o colorido, a propriedade da linguagem de acordo com o objetivo almejado da construção de uma forma inovadora, assim como a originalidade do enfoque, do ponto de vista ou modo de ver as coisas. Percebemos, ainda, a claridade das idéias e a correspondente transparência expositiva, mesmo em se tratando de prosa poética ligada à temática metafísica, assim como, a sinceridade na percepção do ser de enunciação e a brevidade dos textos.Outra característica importante na linguagem jornalística, segundo Vivaldi (1979) é o desvelamento de percepções para o leitor, projetando uma nova luz sobre o mundo e a vida. Outra característica percebida é a técnica piramidal do relato cronológico que se divide em três momentos: a introdução, (começo atrativo) o desenvolvimento interessante e a culminação ou final concreto que percebemos nos textos de Pompéia.

Ao mesmo tempo, trazemos ao público leitor os textos ilustrados pelo autor, comentando sucintamente o perfil de um periódico - A Gazeta da Tarde - e da revista "A Galeria Ilustrada” (1888-1889), até então, a responsável pela única edição de seus textos/imagem. Os textos foram publicados recentemente em um artigo da revista, constante das referências: Fragmentos de Cultura (Goiânia, Editora da UCG, 2005).

Buscamos compreender as razões da escolha de Pompéia quanto às técnicas literárias usadas em suas canções, os tipos de pontos de vista adotados, a organicidade de seus textos, considerados esparsos, até então, pela recepção crítica, e as variações do modo de linguagem, entre textos de título equivalente, publicados em periódicos e, posteriormente, em livro. Em síntese, nosso estudo quis determinar como se deu a transformação dos textos trabalhados exaustivamente pelo autor, durante mais de doze anos, cujo exercício o levou a criar uma forma híbrida - a prosa poética de suas canções.

É inegável o renome de Pompéia, como autor de $O$ Ateneu, que ele teria escrito em três meses. Assim, intrigou-me a pouca atenção dada a suas Canções sem metro, conjunto de poemas em prosa, que o autor sempre considerou sua obra prima e burilou incansavelmente, por mais de uma década. A recepção crítica, com poucas exceções, tem repetido inúmeras 
vezes, que Raul Pompéia escreveu uma única obra prima, O Ateneu, publicado em 1888, pela primeira vez, mas que ele prosseguiu burilando e a edição em que aparecem suas revisões só foi publicada em 1906. Todavia, discordamos dessa colocação, pois o valor literário de suas canções ainda não foi percebido, sobretudo em relação à criação de um novo gênero, no Brasil.

Fizemos uso, para a análise dos textos de Raul Pompéia, dos postulados teóricos da literatura, principalmente quanto aos itens que possam contribuir para a compreensão de sua prosa poética, pouco estudada até agora.

Fizemos uso, especificamente, dos traços gerais da teoria do impressionismo, de Francastel (1974 apud RIBEIRO, 2001), que faz aplicação dessa teoria no romance O Ateneu. Utilizamos, ainda, dos postulados teóricos necessários à compreensão do jornalismo ligado à literatura, no século XIX, assim como de informações necessárias ao entendimento da presença do visual em sua linguagem verbal e do perfil de suas ilustrações em seus textosimagem, ligados ao jornalismo e à literatura.

Acreditamos que tais postulados tenham sido úteis para nos ajudar a explicar como e por que Raul Pompéia tornou-se o escritor que foi, demonstrando o valor literário de Canções sem Metro, na imprensa e ficção do século XIX, assim como, a sua contribuição inovadora. A título de maior esclarecimento, incluímos conceitos sobre poesia e prosa que introduziram a discussão da hipótese, a análise da linguagem de Pompéia na criação de um novo gênero no Brasil.

Segundo Paz (1976), o ritmo não só é o elemento mais antigo e permanente da linguagem, como ainda não é difícil que seja anterior à própria fala. Em certo sentido pode-se dizer que a linguagem nasce do ritmo ou, pelo menos, que todo ritmo implica ou prefigura uma linguagem. Assim, todas as expressões verbais são ritmo, sem exclusão das formas mais abstratas ou didáticas da prosa. Então, para distinguir prosa e poema basta perceber que o ritmo se dá espontaneamente em toda forma verbal, mas só no poema se manifesta plenamente. Ou em textos poemáticos como os de Pompéia. Exemplificando, cito trechos de O Ateneu e suas Canções sem metro. Deixar o pensamento em liberdade, divagar por meio de questionamentos cosmogônicos, a exemplo da prosa poética de Pompéia, ligada ao jornalismo e à literatura, que analisamos, é regressar ao ritmo; as razões se transformam em correspondências, os silogismos 
em analogias e a marcha intelectual em fluir de imagens. Mas o poeta busca a corrente rítmica que, fatalmente, tende a manifestar em imagens, e não conceitos. O poema apresenta-se como um círculo ou uma esfera: algo que se fecha sobre si mesmo, universo auto-suficiente e no qual o fim é também o princípio que volta, se repete e se recria.

Esta constante repetição e recriação é o ritmo, constante das Canções sem metro, uma vez que seus poemas em prosa se concretizam como um dos seus traços distintivos e a proposta de se constituir um gênero distinto e, ao mesmo tempo, negar as formas existentes em nome da liberdade criativa: busca antinômica de uma síntese entre destruição e criação, enfim, a retomada de uma tensão eterna nas formas da arte, entre a ordem e a liberdade. E percebe-se que o estilo de Pompéia nas canções trabalhadas para atingir o gênero híbrido da prosa poética é composto por sua visão de mundo, como veremos adiante. Brunel (1997, p.734) diz que o mito representa uma forma acabada e complexa do que chamamos linguagem simbólica ou significativa, uma vez que o sujeito humano exprime de fato a si próprio, em oposição à linguagem dos objetos que é designativa, informal e utilitária. Tudo aquilo que dá sentido e valor ao homem existente, tudo que é expresso, passa por essa linguagem simbólica, da qual a poesia ou a prosa poética, assim como a linguagem religiosa são expressões privilegiadas.

Essa linguagem simbólica é essencial à existência, mesmo porque é poeticamente que o ser humano habita a terra. Para o homem moderno e racional, a exemplo de Pompéia, com seu realismo subjetivista, é impossível atingir o pensamento mítico puro, como nossos ancestrais. Daí, em seu processo criativo de um novo gênero ele expressa a sua busca de um mito cosmogônico por meio da organicidade do conjunto das Canções sem metro em que percebemos uma relação de simbiose com a racionalidade metafísica ou cotidiana, como vem sendo feito pelas grandes religiões, pelas grandes obras poéticas e com a psicologia.

Todorov e Cohen afirmam não haver em princípio qualquer diferença entre verso livre e prosa poética. Entretanto, Hegel, citado por Aguiar e Silva (1990, p.193) diz que: “o que forma o conteúdo da poesia lírica, não é o desenvolvimento de uma ação objetiva, alargando-se aos limites do mundo, em toda a sua riqueza, mas o sujeito individual e, assim como a maneira segundo a qual a alma, com os seus juízos subjetivos, as suas sensações, toma consciência de si próprio no seio deste conteúdo.” Essa afirmativa de Hegel, em seu livro, Estética (1944), vem ao encontro exato do que constatamos na prosa poética de Raul Pompéia. Ciente do talento, da seriedade e da 
disciplina do autor, em relação aos seus textos, assim como do tratamento especial que ele dedicou à sua prosa poética, o que nos provocou, no estudo das Canções sem metro, de Pompéia, foi desvelar a razão de seu pouco reconhecimento pela crítica. Então, buscamos descobrir seus valores. Nossa intenção inicial foi o estudo da prosa poética ligada ao jornalismo literário, todavia tivemos conhecimento de que o autor foi exímio desenhista e ilustrava não apenas seus textos, mas de amigos ou outros contemporâneos. Suas canções sem metro apresentavam ilustrações específicas e ele sempre teve o intuito de publicá-las assim. Infelizmente, o fato não aconteceu, pois a obra foi editada pela interferência de familiares e amigos. A única publicação de dez canções ilustradas, cedidas pelo próprio autor, como já dissemos anteriormente, aconteceu em uma revista do Paraná, intitulada A Galeria Ilustrada (1889-1889).

A obra ficcional de Raul Pompéia desenvolveu-se sempre ligada à imprensa e ficção do século XIX. Aliás, essa era uma maneira que muitos escritores encontraram para sobreviver e continuar seu trabalho literário. Até a industrialização da imprensa, o que ocorreu a partir do século XX, era perfeitamente possível aliar as duas atividades. Mesmo porque o jornalismo ainda não tinha uma linguagem própria, mais objetiva, a linguagem literária e a jornalística quase se confundiam, então, e os proprietários dos jornais pagavam aos jovens escritores por colaboração no jornalismo literário.

Esta pesquisa está ligada à imprensa e à ficção do século XIX, tendo como meta o estudo da linguagem na prosa poética de Raul Pompéia, publicada nos periódicos da época. Para isso selecionamos os textos ligados ao jornalismo literário que consideramos os mais representativos para o objetivo proposto, analisando as transformações ocorridas entre títulos equivalentes, publicados na "Gazeta da Tarde”, em janeiro de 1886, e sua outra versão, burilada pelo autor e que comporia a edição póstuma de Canções sem Metro. Mas comentaremos o conjunto visando comprovar a organicidade das canções em prosa poética.

Nossas leituras se encaminharam, então, através de um raciocínio, o de que a trajetória de Raul Pompéia era a busca de um novo gênero poético, livre dos movimentos literários anteriores. E certamente as contradições de sua sensibilidade artística não poderiam deixar de ser expressas em seus textos, como apresentaremos ao longo do desenvolvimento deste estudo. Aqui relacionamos e descrevemos os capítulos propostos de maneira sucinta. 
No primeiro capítulo reservado à recepção crítica e ao perfil literário de Pompéia, sintetizei a recepção crítica de alguns de seus principais estudiosos. Araripe Júnior, Eugênio Gomes, Coelho Neto, Suzanne Bernard, Elói Pontes, Camil Capaz, Afrânio Coutinho, Maria Luiza Ramos, Venceslau Queirós, Sonia Brayner, Lêdo Ivo, Therezinha Bartholo, Leyla Perrone Moisés, José Alcides Ribeiro, Heitor Martins, Lopes e Silva, entre outros, que estudaram ou estudam a biografia e a poética de Pompéia, trazendo contribuição para o entendimento de sua prosa poética. Acrescentei também Da Cal (1969) cujo modelo de analise estilística subsidiou nossa análise.

Optamos, ainda, por transcrever recortes da recepção crítica, relativa à sua poética e aos poemas em prosa de Pompéia, especificamente, desde o século XIX até os dias de hoje, de modo que as citações não perdessem o valor do período em que se contextualizam.

Em razão de o objetivo da pesquisa constituir-se do estudo da prosa poética ligada ao jornalismo e à literatura, de Raul Pompéia, na segunda parte do primeiro capítulo, apresentamos todo o histórico e a recepção crítica relativa à criação inovadora de suas canções, observando de maneira interdisciplinar tudo que possa ter contribuído para sua composição. Sobre a estética do poema em prosa e as discussões em relação ao tema, sua caracterização e a possibilidade como gênero literário híbrido são de fundamental importância para que as teorias se libertem de seus quadros tradicionais. O deslocamento da fabulação, em beneficio da criação de um gênero híbrido e inovador, é priorizado dentro de um universo temático fortemente organizado no seu conjunto de relações.

No segundo capítulo, julguei pertinente incluir algumas informações sobre a imprensa e a ficção à época de Pompéia, sobretudo relativas ao periódico A Gazeta da Tarde e A Galeria Ilustrada. Naturalmente incluí uma descrição sumária da revista e um dos textos-imagem de Pompéia foi comentado. Os demais textos ilustrados estão em anexo e enumerados no índice de textos-imagem, tendo em vista sua ligação com o jornalismo e a literatura.

Descrevi de modo sucinto a imprensa daquela época, enfatizando o periódico de onde extraí o corpus: A Gazeta da Tarde, ano VII, 21 - 29 de janeiro de 1886. Os textos têm formas correspondentes à versão selecionada, que constam da quinta parte do livro, Canções sem metro. 
O objetivo deste capítulo é mostrar a situação do jornalismo literário do século XIX, apresentando dados constantes do mencionado periódico e de A Galeria Ilustrada (1888-1889).

No terceiro capítulo, foram analisadas as canções selecionadas como as mais representativas, publicadas primeiramente em periódicos, de acordo com o objeto de nossa pesquisa - “Raul Pompéia: jornalismo e prosa poética”. Portanto, selecionamos as canções mais representativas, publicadas em A Gazeta da Tarde, 21 - 29 de janeiro de 1886. Foram comparadas as versões correspondentes, impressas em jornal e, posteriormente, em livro, haja vista que este estudo está ligado à imprensa e ficção do século XIX. Este capítulo inicia a análise do corpus, partindo dos aspectos de gênero e dos recursos estilísticos, presentes nos textos que os compõem, como os símbolos metafísicos, as imagens visuais impressionistas, o dialogismo intertextual com escritores europeus e técnicas de composição de movimentos posteriores, além de outros recursos poéticos que foram reconhecidos no decorrer do estudo.

Assim, recorremos aos arquivos da Biblioteca Nacional (BN) no Rio de Janeiro, pesquisando os periódicos micro-filmados e adquirindo, posteriormente, suas cópias digitalizadas. Nesse capítulo os textos foram escaneados e reproduzidos como foram publicados em A Gazeta da Tarde, ano VII, no período compreendido entre 21 e 29 de janeiro de 1886.

No quarto e último capítulo, os textos correspondentes das canções compiladas em livro são comentados em diálogo intratextual com a versão jornalística, de acordo com a seqüência, abaixo mencionada.1. Rumor e Silêncio; 2. Vulcão Morto; 3. Os Continentes; 4. Os Deuses; 5. Transit ; 6. Solução; 7. Tormenta e Bonança; 8. Conclusão. Portanto, nesse capítulo daremos continuidade à análise das Canções sem Metro, em sua versão em livro, estabelecendo um diálogo com a versão original do periódico.

Explicitadas as nossas principais preocupações, relacionadas ao esclarecimento lingüístico e literário de palavras e conceitos, e não esquecendo a proximidade do pensamento poético, teremos uma progressão de continuidade e de aprofundamento do pensamento. Este pode ser mais adequadamente refletido e compreendido por meio do recurso a uma diversidade potencial de fatores de contexto.

É importante ressaltar que devido ao trabalho estar ligado ao jornalismo, priorizamos a análise da versão selecionada do periódico, cujos textos aparecerão também no lay out do 
jornal, apenas dialogando intratextualmente com os textos correspondentes no livro. Isto se justifica também pelo fato de as Canções sem metro ainda não apresentarem uma versão completa em livro, uma vez que elas foram compiladas parcialmente, nas três edições das quais foram objeto, desde 1900. No entanto, elas serão mencionadas sempre em maiúsculas, independentemente de terem sido publicadas na edição inicial que o autor almejava como definitiva e denominou de Canções sem metro. Esclareço que acrescentei ao corpus um texto inédito, intitulado: Epifania que será comentado no final da primeira parte do terceiro capítulo. Duas das canções recolhidas com a data de 1881, na coletânea de Coutinho (POMPÉIA, 1982, p. 15), não trazem identificação de sua fonte de pesquisa. A título de esclarecimento, acrescento que acompanha o texto um CD com as cópias digitais dos textos retirados de $A$ Gazeta da Tarde, de 21 a 29 jan 1886, pesquisados na BN do Rio de Janeiro e constantes do corpus. Também as cópias digitais dos textos de Pompéia publicados em A Galeria Ilustrada, conforme o índice. 


\section{RECEPÇÃO CRÍTICA E PERFIL LITERÁRIO DE POMPÉIA}

Como se percebe a crítica sempre deu muita atenção a $O$ Ateneu, mas a recepção crítica em relação à sua prosa poética de Pompéia é bastante escassa, uma das razões que contribuíram para a escolha deste tema para estudo. Ressalto a importância da publicação de toda sua obra, em dez volumes, organizada por Afrânio Coutinho, com a assistência de Eduardo Coutinho. A melhor crítica sobre as Canções sem metro foi escrita por Ivo (1963), além dos artigos que citamos de Therezinha Bartholo e, mais recentemente, de Heitor Martins, o artigo no jornal O Estado de São Paulo, com o título “As canções sem metro, cosmologia do malogro”. Ainda, Lopes e Silva (2004) em seu ensaio: A Filosofia e a História em Pompéia, dentre outros artigos desse mesmo autor.

Quero esclarecer que com o intuito de apresentar uma amostragem do panorama crítico e do perfil literário de Pompéia, optamos, às vezes, por utilizar a técnica do hipertexto, evitando, em algumas ocasiões, cortar as expressões da época em questão: o século XIX. Desta forma estaremos apresentando uma visão crítica de sua poética neste capítulo introdutório, interferindo sempre que necessário, com o objetivo de mostrar a riqueza das contradições de sua fortuna crítica, ao longo do tempo. Segundo Heim (1993), o hipertexto é um modo de interagir com textos e não só uma ferramenta como os processadores de textos. Por sua característica, o usuário interliga informações intuitiva e associativamente. Através de saltos que marcam o movimento do hipertexto o leitor assume um papel ativo, sendo ao mesmo tempo co-autor. Percebemos que o hipertexto possibilita novas formas de ler e escrever, um estilo não linear e associativo, em que o texto primeiro, segundo, original e referência são superados.

Todavia, neste estudo, em virtude do caráter acadêmico do trabalho, preferiu-se o conceito de Levy (1993) em que o hipertexto constitui-se de um conjunto de nós ligados por conexões. Ou seja, aqui os nós são os recortes constantes da fortuna crítica de Pompéia e as conexões são nossas pequenas intervenções, a título de maior compreensão da recepção de Raul Pompéia. 
E voltando à recepção crítica de Pompéia, esclareço que, segundo Coelho Neto (1926), o início das primeiras manifestações do romance modernista brasileiro data desde a publicação das obras de Raul Pompéia, Graça Aranha, Lima Barreto até Tarso da Silveira, apontando os três primeiros como precursores de nossa ficção atual.

Raul d’Ávila Pompéia (1863-1895) é comumente estudado dentro da época realista, no decorrer da segunda metade do século XIX. Em verdade a obra de Raul Pompéia, notadamente as Canções sem Metro e O Ateneu, estão filiadas ao simbolismo, tendência literária que, como é sabido, abriu caminho à maioria das inovações ou à revolução formal do modernismo. Nestas condições, destacadamente com o romance $O$ Ateneu, que teve franca repercussão no movimento modernista, como objeto de estudo crítico, por Mário de Andrade ou como fonte de influências, em José Lins do Rego, é que os estudos críticos, inicialmente, situam Raul Pompéia como um precursor do citado movimento literário. Todavia, essa questão pode merecer nova pesquisa, uma vez que o objetivo deste estudo é a prosa poética de Pompéia ligada ao jornalismo literário.

O Ateneu é uma obra totalmente revolucionária na ficção brasileira de fins do século XIX, surpreendendo a crítica da época e a contemporânea, quanto às técnicas de composição e ao conteúdo. Um de seus capítulos, ou seja, o sétimo capítulo da segunda parte da obra é de natureza autobiográfica. Num retorno à infância e à adolescência, o ser de enunciação em Pompéia mostra ao leitor como o romancista fixou as suas primeiras impressões, ao se colocar em contato inicial com a vida. Conhecendo os homens, sentindo a revelação do sexo, descobrindo o mundo das emoções, e deslumbrando-se com as primeiras reflexões sobre os ensinamentos da sabedoria humana. O livro muitas vezes nos parece que é uma confidência e, numa antecipação surpreendente, pertinente a uma análise psicológica, revela os choques que a sensibilidade artística do autor recebeu, contribuindo para sua imaturidade emocional.

Sob o último aspecto indicado, a obra revela a aguda sensibilidade do autor, bem como a sua poderosa intuição, o que se completa com a transposição de cultura geral que nela se verifica. Raul Pompéia traz para o romance a música, como recurso expressivo de certas emoções indizíveis; fala de arte em geral; reflete sobre a história, a filosofia; e tudo isto, bem ajustado ao romance, salvo uma ou outra exceção, corresponde à própria necessidade de expressão do romancista. Isto pode ser explicado pelo fato de o escritor haver redigido, na vida 
adulta, mas expressando, por meio de suas técnicas de composição, as impressões de sua “crônica de saudades”.

As observações constantes, desse pequeno esboço crítico, são, segundo Castello (1975, p.123-5), novas em relação à ficção brasileira anterior a Raul Pompéia, portanto, uma antecipação de tendências literárias posteriores.

Vejamos a seguir o perfil de Pompéia, descrito literariamente por Araripe Júnior, em periódicos da época, dezembro de 1888 e, posteriormente, publicada em fortuna crítica, pela Casa Rui Barbosa, tendo Eugênio Gomes como organizador de pesquisa e sendo dirigida por Coutinho (1960).

“Talvez pelo processo de cerebração, sucede-me pensar no autor das Geórgicas sempre que me encontro com Raul Pompéia (...) É quase uma obsessão. Quando o encontro na Rua do ouvidor, rubro, vergonhoso, vergado ao peso de uma responsabilidade literária de 40 séculos, levada ao cubo: ou o vejo, no círculo de amigos íntimos, expondo, assombrado e febril, uma teoria nova da arte, da arte que não chega para todos; ou o diviso de longe, metido para um canto, postado em uma esquina, a olhar para o corrente do povo, preocupado com a correção que a linha da vida tivera outrora; quando o imagino no lar, estudando e escrevendo com o mesmo cuidado, como a mesma pudicícia que a moça poria, em ocultar os seios de vistas indiscretas; com o sangue sempre agitado pelo entusiasmo dos grandes mestres, pela tortura das grandes coisas; perturbado pela enormidade da arte, reincidindo na idéia de buscar uma forma calma, que é, enfim, a tranqüilidade da própria consciência crítica; seqüestrado do mundo, apesar de residente em pleno agora, a consertar o pince-nez, a fixar com a vista uma verdade que não há, através de um temperamento delicado e de uma literatura infinita, que o domina como se constituísse a única realidade da vida; quando, finalmente, o surpreendo a traduzir as suas dúvidas num riso seco, desequilibrado, paradoxal e ao mesmo tempo adorável (...) Como uma sombra simpática aglutinada ao Raul que todos conhecemos, aquela "doce natureza de criança, cândida, amável, de disposições sempre benévolas e pacíficas”, de que fala Teuffel, aquele optimus Virgilius bônus ut melhor vir non alius quisquam, das odes de Horácio.Tal é a força ilusionista da figura virgiliana do original autor d’O Ateneu, que, em certas ocasiões, me parece até vê-lo na via Ápia meditando a sua Eneida, titubeante, sob a preocupação da forma que teria de dar o verso - Tu marcellus eris." 
As impressões de Araripe, embora pessoais, não perdem a sua importância. No estudo que esse crítico também publicou nas colunas do mesmo jornal, "Novidades” (1889). Falando do romance naturalista, ele afirma que o narrador em: O Ateneu é um analista fino, sugestivo, pintor delicado, incisivo, observador de impressões pessoais e o mais sobressaltado que era possível imaginar, neste país de pessoas irrequietas. E prevê a relevância do papel que Pompéia teria na literatura brasileira, de fendendo que há homens de ação e homens de reflexão. A atividade poética não podia escapar a essa lei. Assim, existem artistas de características objetivistas ou subjetivistas, a exemplo de Pompéia. O crítico faz referência à primeira edição de $O$ Ateneu, uma vez que a versão burilada pelo autor foi publicada em 1906.

Ainda parafraseando Araripe, em outro artigo de jornal, compilado na obra citada anteriormente, o crítico diz que Raul Pompéia, em seu texto, publicado em um jornal da época, encarregou-se de traçar o seu próprio perfil, no tipo de um poeta que, obsedado pela idéia de um poema, cujos lineamentos fosforizavam de longa data em sua cabeça, depois de desenvolvê-la, "passar mentalmente por todos os processos de composição imagináveis, acabou por convencer-se de que toda a tradução do pensamento humano era uma queda satânica, um suplício de Prometeu, e que, neste caso, mais valia impedir que esse poema se cristalizasse no bico da pena do compositor” (op. cit., p. 130).

O desequilíbrio entre a aspiração e o poder de execução é a causa primordial de todas as vanguardas de que as literaturas têm dado exemplos ao longo de sua história. Daí surgiu um movimento da época, como o simbolismo e as manifestações do pessimismo que tomaram a forma de um niilismo literário. Todavia, apesar do uso constante do símbolo, em razão da poeticidade de seus textos, Raul Pompéia jamais se tornou um simbolista hermético e a sua linguagem simbólica é compreensível a todos.

O autor foi criticado devido ao seu pessimismo, no entanto, este traço pode ter contribuído para o possível excesso de subjetivismo. Mas pessimismo não constitui característica apenas do século XIX, conforme comprova a história literária. A meu ver, Raul Pompéia não é apenas um pessimista; mas, sobretudo, um realista subjetivo, um perfeccionista literário. Talvez, seu pessimismo esteja ligado à falta de uma crença, porque o homem não desespera enquanto crê nalguma coisa. Exemplifico com seu poema em prosa, que integra o 
corpus, “Tormenta e Bonança, em que ele canta: (...) “ os homens (...) à voz dos profetas se acorbadaram; refugiaram-se nos templos”, inutilmente.

O artista exagera, dissolve-se na visão literária. Nessa decomposição de suas forças pela obra de arte, e no contraste, que resulta desse estado, com a aspereza do ambiente, reside em Pompéia, todo o preconizado pessimismo daquele século. O pessimismo de Raul Pompéia pode ser reduzido, em última análise, a uma pronunciada tendência para o sutil. Vivendo no Brasil, do século XIX, o seu temperamento, o seu exagerado subjetivismo obriga-o a passar primeiramente pela metáfora e pela antítese apocalíptica. A crença na palavra viva põe-no em seguida, em dialogismo com o espírito parnasiano.

Ninguém ignora o papel que o verbo, o princípio da subordinação do pensamento à forma, exerceu, nos poetas dessa escola. Pompéia tentou, nas Canções sem Metro, perseguir essas inacessíveis regiões da poesia rosicler. Porém, seu espírito investigador, muito amigo da observação aguda, fez com que ele se transportasse às concepções modernas em dialogismo intertextual com o futuro.

Sabe-se que Raul Pompéia manifestou-se, em O Ateneu, um psicólogo sutil. Seu espírito analista, claro, transparente, não lhe faltaram qualidades indispensáveis para mostrar que além de um artista, nesse escritor existe um filósofo, um pensador. E apesar de em certos momentos, ele apresentar traços simbolistas, suas inúmeras qualidades provaram que aquele caminho hermético seria incompatível com as suas tendências profundas para o exame e para a reflexão. O fato é que a poética pompeiana mostra as qualidades de psicólogo, de estilista, de analista sutil, muito talento, seriedade e disciplina, nesse escritor.

Raul Pompéia preocupava-se com uma teoria de linguagem métrica, que havia de constituir a excelência da prosa do seu livro, como lhe proporcionar a colocação, na boca de um dos seus personagens, de um discurso que é a síntese do seu espírito. Posteriormente seu esforço culminou no valor ainda incompreendido de suas Canções sem metro.

O temperamento de Raul Pompéia achou, na teoria da instrumentação literária, um largo campo para desenvolver-se. Citamos seu texto em que esclarece sua poética, ainda constante da obra crítica de Araripe Júnior, redigida em sua coluna de “Novidades”, em 18, de dez. 1988 (op.cit., p.141-2.) 
“Sobrevive ainda o poema consolador e supremo, a eterna lira, diz (Pompéia).

“É a arte de hoje.

Reinou primeiro o mármore e a forma; reinaram as cores e [o] contorno; reinam agora os sons, música e a palavra. Humanizou-se o ideal. O hino dos poetas do mármore, do colorido, que remontava ao firmamento, fala agora aos homens, advogado enérgico do sentimento.

Sonho, sentimento artístico ou contemplação, é o prazer atento da harmonia, da simetria, do ritmo, do acordo das impressões com a vibração da sensibilidade nervosa. É a sensação transformada . O coração é o pêndulo universal dos ritmos. O movimento isócrono do músculo é como o aferidor natural das vibrações harmônicas, nervosas, luminosas, sonoras. Graduam-se pela mesma escala as impressões e os sentimentos do mundo. Há estados de alma que correspondem à cor azul, ou às notas graves da música; há sons brilhantes como a luz vermelha, que se harmonizam no sentimento com a mais vívida animação.

A representação dos sentimentos efetua-se de acordo com estas repercussões.

O estudo da linguagem demonstra.

A vogal, símbolo gráfico da interjeição primitiva, nascida espontaneamente e instintivamente do sentimento, sujeita-se à variedade cromática do timbre, como os sons dos instrumentos.

Gradua-se em escala ascendente $\mathrm{u}, \mathrm{o}$, a, e, i possuindo uma variedade infinita de sons intermediários, que o sentimento da eloqüência sugere aos lábios, que se não registram, mas que vivem vida real nas palavras e fazem viver a expressão, sensivelmente enérgica, emancipada do preceito pedagógico, de improviso, quase inventada pelo momento.

Há ainda na linguagem, o ritmo de cada expressão.

Quando o sentimento fala, a linguagem não se fragmenta por vocábulos, como nos dicionários. É a emissão de um som prolongado, o crepitar de consoantes, alteando-se ou baixando, conforme o timbre vocal.

O que move o ouvinte é uma impressão de conjunto. O sentimento de uma frase penetra-nos, mesmo enunciado em desconhecido idioma.

O timbre da vogal, o ritmo da frase, dão alma à elocução. O timbre é o colorido, o ritmo é a linha e o contorno. A lei da eloqüência domina na música; colorido e linha, seriação de notas e andamentos; domina na escultura, na arquitetura, na pintura: ainda a linha e colorido.”(op.cit. p. 142-3).

A partir destas colocações do autor d' O Ateneu e de Canções sem metro, percebe-se que ele se deixa levar gradualmente pelas linhas metafísicas do seu temperamento. Esse fenômeno tem sua explicação no mecanismo dos espíritos de ordem subjetiva. Raul Pompéia leu a Métrica natural da linguagem, de Pierson, e esse livro pode ter aberto aos seus olhos regiões inexploradas. Caso ele apresentasse um temperamento objetivista, a instrumentação da palavra teria permanecido no 
seu terreno puramente fônico. Mas, dando-se o contrário, imediatamente a nova teoria tomou, em sua imaginação, um novo rumo, de acordo com sua filosofia literária. Assim, à ambigüidade de idéias, Raul Pompéia acrescenta elementos de sua própria sua criação artística.

E a prova de que a teoria da palavra instrumentada não o prejudicou está na clareza do seu romance, na nitidez da frase e no destaque, não só das figuras, como dos sentimentos que tumultuam em $O$ Ateneu e nas suas Canções sem metro. Raul Pompéia era imune ao misticismo clássico, foi um escritor consciente, preocupado e de inegável faro estético, segundo Araripe Júnior (1888).

E tudo isto se reduz à maneira particular pela qual esse interessante artista sabe associar as imagens que povoam o seu cérebro, ou seja, tudo isto se explica pelo modo por que a natureza o obriga a sistematizar as suas sensações. E felizmente, para as letras brasileiras, a música e o colorido são dons naturais em Raul Pompéia. Nesse terreno, a visão se produz para ele de forma clara e positiva. Apesar de tentado pelo desejo de exprimir o invisível, apesar de suas tendências de artista aristocrático e sutil, repudiou os exageros do simbolismo. Suas obras atestam que o espírito do escritor não se evadiu da realidade As suas construções mantêm-se diferenciadas e modernas, com a devida capacidade para suportar toda a variação complexa do pensamento dos dois séculos que o sucedem. Raul Pompéia apenas segrega-se das sensações de conjunto, porque ele não é um realista objetivista.

Concreto por partes, seu espírito torna-se abstrato apenas quando das imagens particulares ele procura remontar-se às gerais, aos grupos, às coleções, ao todo. Apresentava espírito analítico e positivo, no que diz respeito às coisas destacadas. O autor de O Ateneu e das Canções sem metro era capaz de impressionar-se e de experimentar uma sensação profunda diante de qualquer canto de paisagem.

Porém, desde que se trate de uma associação de aspectos, quer de natureza exterior, quer da interior, a sensação de Raul Pompéia torna-se completamente negativa. O seu espírito não pode vibrar; a sua fosforização cerebral extingue-se e o artista, na angústia que lhe causa essa ausência do sentimento de conjunto e a presença da abstração incômoda, aflitiva a toda a alma poética, passa a construir uma fórmula que seja capaz de dar unidade às conclusões anteriormente obtidas pela sensação analítica. Essa fórmula abstrata, contudo, que penetra no 
domínio da cerebração inconsciente do artista, converte-se imediatamente em uma espécie de ilusão benéfica para o leitor ou para o estudioso da obra cinzelada pelo artista escritor.

Impossibilitado de dar às suas idéias concretas, um centro concreto; por necessidade orgânica da obra de arte, ele é obrigado a buscar uma subordinação qualquer, que mantenha em equilíbrio as diversas partes que compõem a sua criação. Daí o recurso: sair do terreno objetivo e apelar para a síntese subjetiva. Pois, a integração puramente objetiva desses trabalhos artísticos está fora do círculo de suas aptidões cerebrais e seu estilo se renovaria no humorismo e na clarividência. Todo o espaço do romance psicológico está aberto ao talento de Raul Pompéia; e a arte estereotipou-se inteira no seu romance O Ateneu.

O romance psicológico já existia quando Raul Pompéia surgiu nas letras nacionais. Mas ele desenvolveu a sua estratégia própria. Sendo poeta, apesar de uma reflexão profunda; ter capacidade de descrever sentindo, de poder analisar os fatos psíquicos e mostrar o aparelho interno funcionando a descoberto, numa fiel adaptação ao ambiente: são fatores percebidos e que comovem o leitor de $O$ Ateneu, cuja originalidade não pode ser questionada. Cético literário, o Raul Pompéia d’O Ateneu, procura reconstruir o passado de uma alma que possui várias realidades, por meio de significações claras e precisas.

Raul Pompéia diz, por exemplo, ao começar o seu romance, que a vantagem única desse poema artificioso e sentimental com que as mães nos cercam durante os primeiros anos da existência é “fazer mais sensível, a criatura, à impressão rude do primeiro ensinamento” do mundo.

“Lembramo-nos, entretanto, com saudade hipócrita”, acrescenta ele, dos felizes tempos; como se a mesma incerteza de hoje, sob outro aspecto não nos houvesse perseguido outrora e não viesse de longe a enfiada das decepções que nos ultrajam. Eufemismo, os felizes tempos, eufemismo apenas, igual aos outros que nos alimentam a saudade dos dias que correram como melhores” (POMPÉIA, 1976, p. 3).

Ninguém, como Raul Pompéia, apresenta um exemplo de pré-sensibilidade tão característico e eloqüente. É pela arte, em última análise, que Raul Pompéia consegue escapar às 
ameaças da sociedade. Reagir pelo ideal; afirmar a sua existência artística por uma de suas linguagens, jornal, livro, desenho, é o caminho certo por onde caminhou esse verdadeiro talento.

Raul Pompéia, graças à intensidade e à presteza com que tomam forma os mais insignificantes incidentes interiores em sua imaginação, percebe com sua sensibilidade artística as características humanas involuntariamente personificadas. O automatismo da memória e o poder de observação não tardam em assumir as proporções de perfeitas caricaturas.

Sua coleção de charges em periódicos da época e no próprio Ateneu pode comprová-lo. Essa charge é um movimento determinado em Raul Pompéia como conseqüência de seu modo de reagir, que ele eloqüentemente encarnou no personagem Sérgio. O índice do romance revela, todavia, que o autor teve um intuito muito fixo quanto à evolução do caráter de Sérgio.A tese pompeiana no livro é de que o internato teria como função geral fazer esquecer o sexo, provocando um desequilíbrio que nem ao menos encontra o sedativo da contemplação do elemento adverso, como nos estabelecimentos mistos.

O realismo subjetivista é aquele em que o homem consegue tatear o invisível e sondar o inexprimível. É por meio dele que se opera o que Araripe Junior chamou de auto-intoxicação literária, acrescentando que Hamlet é um exemplo genial dessa intoxicação de ordem psíquica. Ainda, segundo Araripe (1888-1889), a auto-intoxicação literária é um fenômeno observado, em todas as épocas, em seus efeitos imediatos. Do mesmo modo que existe uma literatura lírica, existe uma histérica, outra pornográfica; produtos da imaginação ou da sensibilidade. E o intelectual, a exemplo de Pompéia, se impressiona menos com o jogo das forças exteriores do que com o das interiores, firmando sua busca no modo de descobrir a sensação e a forma literária que lhe convém.

O homem, porém, não sairia do sonho ou da visão, se não ascendesse, pela evolução natural das forças mentais, a uma outra ordem de operações. A noção do universo, ou das coisas, não se integra, enquanto o indivíduo não consegue comparar e coordenar, por sua vez, seus sonhos, limitando uns pelos outros, definindo e desenvolvendo o raciocínio. É isto que constitui a integração do conhecimento.

Seja como for, entretanto, embora na esfera intelectual de cada um se encontre essa integração como um fato, não é estranho afirmar-se que naturezas inferiores, dotadas de 
sensibilidade fora do comum, nem sempre conseguem, libertadas da primeira fase subjetiva, passar ao perfeito equilíbrio da integração final.

Pode-se agora avaliar o que, em uma organização móvel desta natureza, não produzirá a contínua superposição de impressões, de observações e de sucessivos esforços de generalização ou abstração limitada a uma única ordem de fenômenos. E é desta espécie, exatamente, que cito Poe, como o melhor exemplo, para ilustrar esta reflexão. O que, todavia, não entra em dúvida é que Edgar Poe fez de sua imaginação o que ele quis e dirigiu o seu intelecto, com uma ciência infinita, para os pontos que mais eficazmente lhe abriam horizontes ao mundo das sensações desconhecidas. Nessas impressões comuns aos gênios literários nada existe de semelhante às impressões ordinárias. Em tais casos os cinco sentidos são substituídos por incontáveis sentidos sublimados.

Na Gênese de um poema, Edgar A. Poe explica de um modo admiravelmente prático como ele conseguia intoxicar-se para empreender a composição dos seus contos e poemas, e de outros recursos de que se utilizava para transmitir a impressão viva dessas obras aos leitores dos seus livros.

Assim, pode-se concluir que, em temperamentos de gênios literários, à semelhança de Põe e Pompéia, existe um poder de conduzir e explorar arbitrariamente uma espécie de espírito subterrâneo ou inconsciente, ou seja, a capacidade de agitar os mais obscuros problemas e darlhes um colorido nunca conseguido no estado normal da inteligência.

A psicologia dessa classe de artistas pode, em última análise, resumir-se nesta expressão: o pânico do belo. E citamos Flaubert, Põe, Pompéia, entre outros exemplos de ascetismo poético que compartilharam essa espécie de prazer em suas aspirações artísticas. No Journal dos dois irmãos Goncourt percebe-se a mesma preocupação A contemplação das coisas ou o espetáculo do mundo não se fundem naturalmente na alma desses torturados da arte.

O belo, para eles, significa o espanto. A aspiração do ideal de composição os faz sempre suar, tremer; as suas inspirações geram o terror. A concepção de uma obra é tortura e suplício em suas vidas literárias. Produzir ou criar remete a um doloroso esforço e à angústia para esses homens das letras (Journal des Goncourt, I, 35). 
De qualquer maneira que o artista proceda para obter as determinações da sua perspectiva interna, é indispensável que ele se subordine às leis naturais da expressão e da linguagem. Pouco importa que se trate de um escritor subjetivo ou de um objetivo. As diferenças só são notáveis quanto ao processo por eles empregado para atingirem aquela perspectiva interna, para formarem o seu microcosmo, de caráter universal, sem o qual não se pode conceber um artista de raça. Desde, porém, que se passe à exteriorização desse microcosmo, as divergências de execução são quase insensíveis.

Forçado pela necessidade de totalizar e unificar a impressão, princípio indiscutível em obras artísticas, Edgar Poe sustentava que um poema não devia exceder certas dimensões, acrescentando que aquilo que nós chamamos "um longo poema, não é, na realidade, senão uma sucessão de poemas curtos, de efeitos poéticos breves”.

Ora, compreendida por este modo a determinação das concepções dramáticas, isto é, como uma invasão de fatos já totalizados e unificados pela vida do artista, pelo mesmo modo pelo qual ela se processa no mundo exterior. Convertendo-se, pois, em formas sintáxicas, quer a elaboração se realize, coletivamente, na imaginação do povo, como acontece com os mitos e com a poesia cíclica, mesmo que se realizem no cérebro de um só homem, esses fatos organizam-se, primeiramente, em núcleos relacionados, entre si, depois subordinam os elementos complementares, para depois se articular, por meio do que se pode chamar: a essência da obra de arte, que é do domínio da histologia literária.

Mudam-se os pensamentos, transformam-se as crenças, acabam-se os preconceitos; mas o que não se altera, apenas se complica, é a sintaxe superorgânica, porque ela está intimamente ligada às leis da morfologia. Para nos convencermos disto, basta superpor os esquemas das obras de arte moderna aos esquemas das obras de arte grega que perduram. Se as leis da expressão fossem antagônicas, a incidência das linhas capitais seria algo impossível; mas é o que acontece. Na descrição, entretanto, na análise, a articulação das partes faz-se toda no espírito do artista.

Aceitando a obra artística como uma máquina de sensações, o gênio moderno tende, cada vez mais, a aproximar-se da natureza, corrigindo a partir na segunda metade do século XIX a dispersão das obras medievais e a indisciplina dos românticos, que raramente pensaram 
na arte curta. De qualquer modo, a arte vai voltando à simplicidade e à economia de esforço com que os gregos já sonhavam, quando, preocupados com a necessidade de pôr o fundo de acordo com a forma, estabeleciam as leis da simetria, da métrica, do ritmo, e dividiam toda a obra de arte em grupos distintos, gravitando em torno de um centro ainda mais visível.

A síntese vem, assim, a constituir o supremo princípio da expressão em literatura; e é com a inflexibilidade desse princípio e desses hábitos literários que o temperamento de cada artista tem de travar luta indefesa, a fim de chegar à manifestação da sua individualidade. Isto se faz por meio do acento e da elipse interior.

O artista subjetivo é livre apenas no modo de firmar ou acentuar os grupos e figuras que seu talento conseguiu relacionar, a síntese da criação e a conseqüente eliminação dos corpos estranhos se operam de acordo com o verdadeiro trabalho subterrâneo. É esse encadeamento, essa particular subordinação que se deve procurar na leitura crítica do livro e nos estribilhos do estilo.

Lúcia Miguel Pereira (apud CAPAZ, 2001, p. 88) em seu livro História da Literatura Brasileira, página 115, chama a atenção para o aspecto da personalidade literária de Raul Pompéia, ao referir-se ao processo de construção de O Ateneu - que ela afirma ser "um livro de interpretação”, afirma, construído “com descrições”, e no qual o romancista "trabalhou quase como um artista plástico”.

Na homenagem a Machado de Assis promovida por homens de letras no Hotel O Globo, em 6 de outubro de 1886, a propósito das comemorações pelos 22 anos da publicação de Crisálidas, Pompéia foi escolhido como um dos oradores do evento. O tema que aborda, “a filosofia pessimista do grande escritor”, não poderia ser mais apropriado, revelador que era da profunda empatia em relação ao homenageado, ao menos nesse aspecto do seu talento ( $A$ Semana, v. 2, p. 93,1886).

Era natural que despontassem ciúmes, comentários sobre possíveis influências, corriqueiros entre homens de letras. Embora alegre e amante da boa palestra, Pompéia por vezes revelava-se susceptível e desconfiado, sentindo-se ferido facilmente com brincadeiras, se notava algum fundo de malícia. Coelho Neto considerava-o de uma honestidade “mórbida”. 
“Certa vez”, narra o autor de A Conquista, “ só por lhe haver eu observado vaga semelhança entre uma de suas canções e um fragmento de Schopenhauer, franziu o sobrolho e, encarando-me ferrenho, rosnou em voz surda:

— Pensa, você, talvez, que plagiei, não é?

E, rápido, fremente, rasgou o papel, fê-lo em migas, atirando-as, com desprezo, à rua”

(COELHO NETTO, op cit., p.60-1).

Na ficção, alguns dos seus contos publicados já começam a revelar um escritor diferente daquele da fase acadêmica de São Paulo, preocupado agora em moldar as emoções em textos trabalhados artisticamente, nos quais os críticos mais próximos logo identificaram a influência dos irmãos Goncourt, escritores de sua especial afeição. Decotes de quinze anos, É morto Pulcinella!, Dia de Gala e Rogério, O Rude são histórias que se enquadram nessa feição, pequenas jóias de tessitura perfeita, por sua fina psicologia e por seu enquadramento peculiar, sendo que nas três primeiras porejam um quente sensualismo, muito pessoal em sua arte de pintar personagens femininos marcados por fascínio irresistível.

Nas crônicas, seguem as críticas aos escravocratas, à época liderados no Rio de Janeiro pelo chefe de polícia Coelho Bastos, personagem de humor azedo a quem aprazia exibir autoridade de maneira arrogante, quer raspando a cabeça de negros suspeitos de terem fugido ao cativeiro, quer combatendo o popular costume do entrudo, tradicional no Rio de Janeiro, em que os foliões se divertiam com seus limões de cheiro e esguichos d'água.

Nesse tempo, entretanto, Pompéia vivia uma fase de pouco entusiasmo, em relação à causa abolicionista, ou porque achasse que aos poucos o problema se encaminharia para uma solução política, ou porque imaginasse, com certa razão, que a guerrilha miúda contra os negreiros não era o método mais adequado para se alcançar um remate definitivo e completo, que alcançasse a nação por inteiro. Em razão disso, vez por outra descambava para a ironia, como ocorreu em relação a candidatura de Quintino Bocaiúva para a Câmara dos Deputados, vaticinando o seu fracasso se insistisse em seu programa de luta contra a escravidão no Brasil, 
que afugentaria possíveis eleitores, pois as classes votantes, afirmava, não estavam interessadas na abolição: "A multidão gosta de esquecer os seus pecados. Por isso há os bailes: circenses. Se um candidato vem
assombrá-la com perspectivas medonhas, embora reais, a multidão volta-lhe as costas.

Fica entendido que quando falo de multidão, refiro-me à multidão que vota; perante a lei, não há outra. O representante da nação não representa o povinho sem renda. Isto não é nação; embora possa vir a ser exército, se as fronteiras quiserem.

A minha multidão tem o que perder.

É a esta multidão que se dirigiu o benemérito jornalista d’O País; é esta multidão que vai abanar com a cabeça ao honrado candidato do $1^{\circ}$ distrito, ao pé de urna. Quem mandou Quintino Bocaiúva ser Quintino Bocaiúva?” (Gazeta da tarde, 24.12.1885).

Foi neste estado de espírito que ele aceitou o convite para ingressar no corpo de redatores do Jornal do Comércio, em meados de 1886. Ali ele viveu uma estranha fase em sua vida de combatente da liberdade, comentando o dia-a-dia da política do ponto de vista governamental, defendendo o ministério conservador do barão de Cotegipe, tecendo elogios ao imperador e ao "seu elevado grau de saber e entranhado amor pelas letras e pelas as ciências".

Ele tecia críticas a políticos do Partido Liberal, como Joaquim Nabuco ou mesmo combatia o açodamento dos abolicionistas, a pretexto de que a libertação já estava próxima, inclusive por contar com o apoio do próprio governo.

Tais deslizes só se podem justificar por se tratarem de artigos de natureza redatorial, vinculados à linha conservadora do jornal e elaborados ao tempo em que o cronista cobria as atividades da Câmara dos Deputados. Só assim podemos entender que ele denomine Cotegipe como, um “estadista ilustre, cujo nome é um patrimônio nacional”, o que sem dúvida era verdadeiro, embora soasse estranho, vindo de Pompéia. Só por obediência a um dever profissional, poderemos aceitá-lo, quebrando uma linha de estrita coerência, a qualificar o estadista baiano como "um brasileiro ilustre, que deve ter glória em oferecer aos seus 
concidadãos a história de uma existência, já longa, consagrada toda inteira à felicidade de sua pátria, história em cujas páginas fulguram traços relevantes do mais alevantado civismo” (Jornal do Comércio, 12.06.1886).

Surpreende, do mesmo modo, vê-lo atacar os movimentos de rebeldia republicana de alguns membros do Congresso. Se é certo que a mudança de regime nunca lhe mereceu a importância do abolicionismo, são no mínimo contraditórias suas opiniões a respeito do deputado mineiro Afonso Celso Júnior, que à época pregava a mudança do regime: “O brasileiro, o mineiro, é eminentemente monarquista; a idéia de república passa-lhe com disfarces pelo espírito sem impressioná-lo. Ele sabe de própria experiência que os pregadores da república não são sérios. A idéia de monarquia é co-natural à índole nacional (Jornal do Comércio, 7.07.1886 apud CAPAZ, 2001, p. 89-98).

O talento de Raul Pompéia, que oscilava entre a literatura e as artes plásticas, passou a dedicar-se por inteiro ao jornalismo, à época um dos poucos tetos que podiam abrigar talentos vocacionados para as letras ou para o desenho, além da função pública, que no Brasil sempre foi o porto seguro dos escritores que comungavam com as diretrizes do governo ou pelo menos não lhe fossem francamente contrários, o que não era exatamente o seu caso, que depois de poucos meses de atividade já tinha abandonado o Jornal do Comércio e só esporadicamente publicava contos ou crônicas na imprensa (CAPAZ, 2001, p. 99).

Há de se considerar que o reconhecimento interno do escritor não parece mais fácil que o externo e essa aspiração se manifesta de várias maneiras. Muitas vezes alguns escolhem o caminho da profissionalização por vias paralelas, como a imprensa, alternativa discutida desde a época de Raul Pompéia, Lima Barreto, Coelho Neto e Olavo Bilac, ou a política, que conferem personalidade pública ao artista; ou quando prefere uma institucionalização não de sua arte, mas de sua pessoa, promessa contida nos regimentos de todas as Academias, as brasileiras e nacionais, bem como as estaduais e as municipais.

Pompéia é visto como iniciador do Impressionismo no romance brasileiro e comparado ao livro “Chansons de Maldoror” (1868), de Lautréamont, por Leyla Perrone-Moisés, em “O Ateneu: Retórica e Paixão”, de 1988; como era moda na época, a crítica denominou o livro de “antropofágico”. Mesmo fora da onda e tendo nada a ver com Oswald de Andrade, O Ateneu 
permanece como base da ficção supra-realista nacional Seus 12 capítulos exibem um "tom de pânico", nos termos forjados, ainda em 1889, pelo crítico Araripe Júnior, que se expande numa escritura "quebrada" semelhante às imagens de lanterna mágica. Araripe Júnior afirma que Pompéia confeccionou "gnomos verbais" cuja energia de expressão se fundamenta na "impropriedade dos vocábulos".

Em 1943, Mário de Andrade denominou a obra de "biografia intelectual". Para José Guilherme Merquior, em "De Anchieta a Euclides", de 1979, ela narra uma paixão e reflete a personalidade "fragmentária e camaleônica" do autor.

Em "Prosa de Ficção, de 1870 a 1920", publicado em 1950, Lucia Miguel Pereira vê no livro o segredo do destino de Pompéia. Para ela, o romance traça o "drama da solidão" de um menino tímido e hipersensível. Pensa que não é romance de tese, apesar de defender uma - a de que os internatos massacram a sexualidade: "Não faz o feitio de Sérgio depender das suas condições físicas e, se apresenta a homossexualidade como quase geral entre rapazes privados de contatos femininos, não a explica em termos biológicos; aliás, não explica nunca coisa alguma. "Não bastasse a megafortuna crítica, o romance recebeu pelo menos duas edições "definitivas", confrontadas com os originais: a de Afrânio Coutinho (Civilização Brasileira, 1981) e a de Therezinha Bartholo (Livraria Francisco Alves, 1976).

Esta edição comentada é, apesar das críticas de Coutinho, a mais completa, pois se debruçou sobre os originais de 126 páginas que o autor vendeu à Alves \& Cia., juntamente com 43 desenhos a crayon (mais tarde vendidos à $\mathrm{BN}$ ), por um conto e meio de réis em junho de 1894. Ao examinar as nove edições "oficiais" anteriores, lançadas de 1905 a 1956, Bartholo concluiu que o original emendado pelo autor havia sido desrespeitado. Este já consistia em uma cópia tipográfica. Munido dela, Pompéia fundiu e separou parágrafos, reposicionou os pronomes átonos e corrigiu palavras e nomes próprios. Ao todo, 18 modificações não haviam sido incorporadas à edição canônica. Elas foram restituídas à versão de 1976. A prova supostamente desapareceu em um incêndio da editora, no fim dos anos 70. O esgotamento das leituras, a consolidação do texto e a morte dos principais estudiosos levavam a supor que o tema estava encerrado. Só que nenhuma das edições de $O$ Ateneu menciona o fragmento da Biblioteca Nacional. 
De fato, ele não tem o condão de alterar o destino e muito menos o arcabouço de $O$ Ateneu. Sugere, porém, uma nova leitura sobre fatos e motivações estéticas em que a obra foi engendrada - aspecto que Gomes intuiu. Considerou que, "pelo imprevisto da idéia original da narrativa autobiográfica", o trecho era uma revelação a ser canonizada pela crítica. Mas não obteve repercussão e seu texto se converteu em raridade.

Eugênio Gomes (1897-1972) foi o literato certo para a ocasião. Teve acesso ao texto porque foi diretor da Biblioteca Nacional entre 1951 e 1956. No período, o teórico baiano se valeu do cargo para fazer descobertas, que anunciou em brilhantes artigos de jornal. Entre outras façanhas, achou uma carta de Byron e, machadiano que era, o manuscrito da peça "Forcas Caldinas", de Machado de Assis, jamais encenada. No artigo sobre Pompéia, informa que a folha foi doada à BN pelo historiador cearense Capistrano de Abreu (1853-1927).

A partir desse ponto, três fatos intrigantes se justapõem. Capistrano foi amigo de Pompéia. Quando este estreou no romance com "Uma Tragédia no Amazonas", editado pela Typogaphia Cosmopolita, em 1880, Capistrano profetizou que Pompéia se devotaria à narrativa esteticista. A incerta altura da década de 1880, Capistrano perdeu um artigo de jornal que o amigo lhe confiara; pode ser até que tenha extraviado e reencontrado a folha com o início de $O$ Ateneu. O fato gerou fúria e o rompimento com Capistrano.

O segundo fato está em Pompéia ter sido diretor da Biblioteca Nacional, tal como Eugênio Gomes. Apoiou a ditadura de Floriano Peixoto e foi convocado a dirigir a instituição. Ocupou o cargo de 21 de junho de 1894 a 30 de setembro de 1895 e foi exonerado no primeiro despacho do novo presidente da República, Prudente de Moraes. A terceira situação é que, atormentado por um artigo injurioso de outro ex-amigo, Luiz Murat, e do adiamento da publicação de um texto seu em A Notícia, Pompéia se suicidou, aos 32 anos, na tarde do Natal de 1895. Seu bilhete dirigia-se ao jornal para o qual colaborava gratuitamente: "À 'Notícia' e ao Brasil declaro que sou um homem de honra". Pompéia atribuía alta importância aos tipos impressos e aos seus escritos e foi classificado como um nevrótico em sua época.

Como sabemos, Pompéia ocupa lugar privilegiado pela recepção crítica, sendo considerado como um dos maiores clássicos da literatura nacional e o escritor de maior característica pessoal em nossa literatura, segundo Bartholo, Jornal do Brasil (19 dez. 1975). 
Ele foi desenhista e caricaturista de alto nível. Este talento parece ter sido um dos seus grandes interesses e, ao mesmo tempo, distração freqüente do escritor, pois até conversando com amigos desenhava em qualquer papel que lhe estivesse às mãos. No Colégio Abílio (na Rua Ipiranga/Laranjeiras/RJ) onde o romancista iniciou o curso preparatório, o desenho era, possivelmente, uma das disciplinas que mais seduziam o futuro artista.

Ainda, segundo Bartholo (1975), em: O Ateneu há trechos de reminiscências do personagem Sérgio que podem ser analisados como registro do interesse do escritor por essa arte. É evidente que Pompéia gostava de desenhar em livros, o que faz supor a existência de outros desenhos do romancista nas obras que compuseram sua biblioteca, infelizmente dispersada tempos depois do desaparecimento do escritor. A crítica literária baseia a hipótese no fato de conterem desenhos de sua autoria três volumes que lhe pertenceram. Entre eles, uma Bíblia Sacra, edição da Vulgata, 1860, livros que chegaram ao alcance da pesquisadora pela mão de pessoa da família de Pompéia. Detalhes do relacionamento artístico de Pompéia com a filosofia cristã estão contidos em seu artigo intitulado: "Raul Pompéia, comentarista da bíblia”, publicado também no Jornal do Brasil (17 nov. 1973).

Bartholo (1971) também questiona o fato de o autor ter burilado O Ateneu, cuja edição foi publicada em 1906, e a crítica não ter dado importância a esse fato, continuando a comentar a versão anterior. Ela faz um estudo intitulado "Raul Pompéia e as variantes d’O Ateneu”, publicado no jornal O Estado de São Paulo (17 out. 1971).

Raul Pompéia não se cansou de aperfeiçoar o estilo, e O Ateneu é uma das poucas obras literárias que receberam cuidados excepcionais de seu autor, mesmo depois de publicada. A primeira publicação do romance foi feita em folhetim (como era comum na época) na Gazeta de Notícias, em 1888. De 08 de abril a 18 de maio foram publicados doze capítulos, numerados em romano, com o título $O$ Ateneu, e a indicação entre parênteses: “Crônica de Saudades”. Cada trecho do folhetim traz as iniciais R. P. e somente a última publicação tem o nome do autor, "Raul Pompéia”, logo abaixo da seguinte data "Rio, janeiro-março de 1888”. Nessa época que parece indicar o período em que o romance foi escrito, vemos que Pompéia só iniciou a publicação depois de terminada a obra, é que, portanto, O Ateneu não é romance que foi escrito ao sabor dos dias para a publicação do folhetim no jornal. A primeira edição em livro apareceu nesse mesmo ano de 1888, feita pela “Tipografia da Gazeta de Notícias”. E nela 
que encontramos as primeiras alterações no texto. Se bem que poucas e mostram nitidamente preocupações estilísticas, razão que nos parece suficiente para afastar a idéia de que possam ter sido introduzidas por mão de alguma pessoa ligada à tipografia ou ao jornal.

É mais do que suficiente para exigir que seja definitivamente afastada a suposição comum de que essa edição é mera reprodução das chapas tipográficas utilizadas na publicação do folhetim. Publicado o livro, Pompéia demonstrou não ter ficado satisfeito com a obra e continuou a trabalhar nela. Foi então que fez outras e muitas modificações. Mas dessa vez tão mais profundas que nos habilitam a afirmar que o romance for refundido.

A primeira edição da Livraria Francisco Alves foi impressa em Paris, na "Typographie Aillaud \& Cie”. O volume indica duas datas: 1906 na capa externa, e 1905 na folha de rosto. Apesar dessa diversidade, podemos dizer que a edição é de 1906, baseando-nos na seguinte informação colhida em Os Anais, nº 67, 25 de janeiro de 1906: "Brevemente estará à venda uma edição nova do Ateneu, o grande romance de Raul Pompéia. O trabalho tipográfico foi feito em Paris, por encomenda da Livraria Alves, que se serviu para a prática desse belo serviço à nossa literatura, da antiga edição, muito refundida pela última demão do inesquecível artista”.Com essa notícia o semanário de Domingos Olímpicos dá duas informações de real importância para nosso assunto: o ano da primeira edição da Livraria Francisco Alves é 1906; o texto se apresenta muito refundido pela última demão do autor.

Segundo Capaz (2001), a obra literária O Ateneu, publicada em 1888, foi classificada pelo autor como: Crônica de Saudades, que pretendia ser, ao que tudo indica, um relato fiel dos seus tempos de internato, mas parece que à medida que o trabalho ia avançado o imaginário do romancista foi-se sobrepondo às suas lembranças, com os dados ficcionais prevalecendo sobre as referências biográficas.

Raul Pompéia é um criador de imagens surpreendentes. A fertilidade de seus "achados” acarreta resultados os mais diversos, do hilariante ao trágico, do trivial ao solene. Pompéia fornece ao leitor uma visualização de locais, personagens e cenas que é, no mínimo, insólita. $\mathrm{Na}$ opinião do crítico, as figuras são profusas, variadas, em grande número e bastante freqüentes e Mário de Andrade acrescenta que, em $O$ Ateneu, não se desdenha a pompa, a eloqüência do dizer é largamente utilizada, e o brilho das imagens, a raridade vibrante das 
comparações, o ritmo opulento atingem o abuso e algumas vezes o mau gosto"(Mário de Andrade, “Prefácio”, O Ateneu, Rio de Janeiro, Câmara Brasileira do Livro, 1954, p. XV).

A trama do romance, O Ateneu, gira em torno das experiências do narrador, Sérgio, enquanto adolescente sujeito ao regime de internato num colégio do Rio de Janeiro, na segunda metade do século XIX. Muito se tem escrito sobre o caráter autobiográfico desse livro, mas aprofundar tal questão está fora do objetivo desta pesquisa, apesar de não ser possível mencionar sua megafortuna crítica em se tratando do estudo de outra obra de Pompéia.

Segundo Giron (2001), em texto publicado na Gazeta Mercantil, o escritor Raul Pompéia cortou $O$ Ateneu pela cabeça. O escritor fluminense fixou o início da versão definitiva de seu romance em um parágrafo mais abaixo, à altura da vigésima terceira linha do projetado texto de abertura. Refugou tudo o que veio antes, o "incipit" do livro, por algum motivo secreto. A decapitação talvez tenha fortalecido a trama: as primeiras linhas retratam o menino Sérgio levado pelo pai à porta de um internato. "Vais encontrar o mundo", diz-lhe o pai. "Coragem para a luta."A situação remete à porta do Inferno de Dante e do Labirinto de Creta; ela antecipa os sofrimentos que o protagonista-narrador viverá no internato, entre eles o despotismo tecnocrático do diretor Aristarco, o comportamento sexualmente ambíguo dos colegas e o incêndio apoteótico reservado ao último capítulo.

O romance saiu em colunas verticais e não no rodapé habitual dos folhetins, na Gazeta de Notícias entre 08 de abril e 18 de maio de 1888, como já foi dito, com grande sucesso, e, em seguida, em volume, pela tipografia do jornal. As duas primeiras versões levaram o seu autor à glória literária na época, tornando-se um clássico da Literatura Brasileira. Mas nessas, assim como nas edições posteriores foi extirpada uma parcela essencial.

Tudo isso se deixa revelar em uma folha de papel almaço cortada pela metade, escrita face a face, de um só lado, com tinta violeta e lápis. As 22 linhas em questão que fazem parte da folha ficaram trancafiadas por cerca de 40 anos num cofre da Divisão de Manuscritos no terceiro andar da Biblioteca Nacional do Rio de Janeiro, sem possibilidade de consulta. De acordo com funcionários da seção, somente em 1995 o documento foi liberado ao público. Até então, dividia espaço com canetas e outros objetos de celebridades intestinas da BN e volumes mais ou menos raros, ocultos como objetos para um museu ulterior. Mesmo assim, nenhum 
estudioso se comoveu com a folha porque ela era guardada com uma cópia de um artigo do crítico Eugênio Gomes, intitulado Um inédito de Raul Pompéia, publicado em 10 de novembro de 1951, no jornal Correio da Manhã.

$\mathrm{O}$ artigo analisa o texto inédito e apresenta uma transcrição preliminar do manuscrito. $\mathrm{O}$ fac-símile da folha foi estampado na revista "Poesia Sempre", de outubro de 1895, sem comentários, com fins ornamentais. O artigo e a reprodução tiraram o fragmento do páreo junto aos caçadores de inéditos que alimentam a indústria de teses e dissertações acadêmicas. Além do que Pompéia saiu de moda na universidade, depois de $O$ Ateneu ter sido entronizado por Afrânio Coutinho - o último grande especialista em Pompéia, falecido em 2000 - como iniciador do Impressionismo no romance brasileiro e comparado ao livro Chansons de Maldoror (1868), de Lautréamont, por Leyla Perrone-Moisés, em O Ateneu: retórica e paixão, de 1988; como era moda na época, a crítica denominou o livro de “antropofágico”.

Mesmo fora da onda e nada tendo a ver com Oswald de Andrade, O Ateneu permanece como base da ficção supra-realista nacional. Traz a sátira ao sistema educacional e ao meio social - o "ouriço invertido", espinhando quem dele toma parte - do Brasil do Segundo Império, um país que o narrador define em termos nada carinhosos: "Charco de 20 províncias, estagnadas na modorra paludosa da mais desgraçada indiferença". Seus 12 capítulos exibem um "tom de pânico", nos termos forjados ainda em 1889 pelo crítico Araripe Júnior, que se expande numa escritura "quebrada" semelhante às imagens de lanterna mágica. Araripe Júnior ensina que Pompéia confeccionou "gnomos verbais" cuja energia de expressão se fundamenta na "impropriedade dos vocábulos".

Em 1943, Mário de Andrade denominou a obra de "biografia intelectual". Para José Guilherme Merquior, em De Anchieta a Euclides, de 1979, ela narra uma paixão e reflete a personalidade "fragmentária e camaleônica" do autor. Em Prosa de ficção, de 1870 a 1920, publicado em 1950, Lucia Miguel-Pereira vê no livro o segredo do destino de Pompéia. Para ela, o romance traça o "drama da solidão" de um menino tímido e hipersensível. Pensa que não é romance de tese, apesar de defender uma - a de que os internatos massacram a sexualidade: "Não faz o feitio de Sérgio depender das suas condições físicas e, se apresenta a homossexualidade como quase geral entre rapazes privados de contatos femininos, não a explica em termos biológicos; aliás, não explica nunca coisa alguma". Não bastasse a 
megafortuna crítica, o romance recebeu pelo menos duas edições "definitivas", confrontadas com os originais: a de Afrânio Coutinho (Civilização Brasileira, 1981) e a de Therezinha Bartholo (Livraria Francisco Alves, 1976).

Essa edição comentada é, apesar das críticas de Coutinho, a mais completa, pois se debruçou sobre os originais de 126 páginas que o autor vendeu à Alves \& Cia., juntamente com 43 desenhos a crayon (mais tarde vendidos à $\mathrm{BN}$ ), por um conto e meio de réis em junho de 1894. Ao examinar as nove edições "oficiais" anteriores, lançadas de 1905 a 1956, Therezinha Bartholo concluiu que o original emendado pelo autor havia sido desrespeitado. Este já consistia em uma cópia tipográfica. Munido dela, Pompéia fundiu e separou parágrafos, reposicionou os pronomes átonos e corrigiu palavras e nomes próprios. Ao todo, 18 modificações não haviam sido incorporadas à edição canônica. Elas foram restituídas à versão de 1976. A prova supostamente desapareceu em um incêndio da editora, no fim dos anos 70. O esgotamento das leituras, a consolidação do texto e a morte dos principais estudiosos levavam a supor que o tema estava encerrado.

Segundo Perrone (1988, p.8), a hipótese de uma leitura do intervalo cultural, capaz de articular autores tão diversos quanto Lautréamont e Pompéia, foi vista com entusiasmo pelos alunos participantes que viam nos seminários um modo de não apenas ler dois autores, mas de fazer da leitura literária uma via de meditação cultural, ampliando, desta maneira, os esquemas em geral apertados das leituras textuais. O incêndio final de $O$ Ateneu passa a ser a melhor metáfora para o intertexto cultural que surge das cinzas dos palimpsestos que, de acordo com a crítica, se chamaram Lautréamont e Raul Pompéia.

Ela afirma que as coincidências são numerosas, como comprovará, mas afasta de início, toda e qualquer hipótese de influência. Na própria França, Lautréamont só ficou conhecido no começo de nosso século; quanto a $O$ Ateneu, ele é posterior à morte de Lautréamont e, aliás, até hoje injustamente desconhecido fora do âmbito de nossa língua. As coincidências decorrem, primeiramente, de experiências existenciais semelhantes e contemporâneas. Isidore Ducasse (em literatura, Conde Lautréamont) nasceu em 1846; Raul Pompéia, em 1863, na história cultural, 17 anos é uma pequena diferença; e, principalmente, é preciso levar em conta que, no século passado, as idéias e costumes europeus levavam algum tempo para atravessar o Oceano. Lautréamont e Raul Pompéia são, pois, contemporâneos. 
O internato brasileiro, no fim do século XIX, era regido pelas mesmas normas de funcionamento dos internos franceses da época. Nosso ensino era marcadamente europeu, e particularmente inspirado no sistema francês. Numerosos mestres vinham aqui ensinar; os manuais escolares eram europeus ou neles inspirados; os currículos, o sistema de promoção eram iguais aos de lá.

A importância da experiência do internato é, em ambos, indiscutível. Quanto a Raul Pompéia, seu romance narra exatamente essa experiência, e com tal amargura que Mário de Andrade não hesitou em ver, na obra, uma "vingança contra seu internato no Colégio Abílio" (Aspectos da literatura brasileira, p. 173).

De qualquer modo, uma primeira diferença deve ser observada, antes de cuidarmos das semelhanças. O tema do internato é explícito, nuclear e mesmo exclusivo n’O Ateneu. Em Lautréamont, esse tema aparece de modo ocasional; não se pode reduzir sua obra a esse tema, embora ele esteja sempre subjacente. De qualquer forma, o que interessa a Perrone (1988) é examinar como experiências semelhantes, num mesmo momento histórico, podem assumir formas estéticas semelhantes: na temática, nas imagens, no estilo, na significação; pelo uso que fazem de um repertório comum, o que é previsível, mas e, sobretudo, pelo uso subversivo e imprevisível, com que transformam esse repertório. Ela pretendeu encarar a experiência desses dois autores menos como uma vivência pessoal do que como "um drama da cultura", para usar a expressão de Bachelard. Ducasse e Raul Pompéia fixaram, em suas obras, um trauma não apenas afetivo, mas algo mais vasto, que podemos chamar de trauma cultural.

O dado priorizado pela pesquisadora é a linguagem, o intertexto. Acrescenta: trata-se de verificar como, num chão discursivo comum, (o do discurso escolar, que é uma síntese de toda a cultura de uma época, mas uma síntese programada, “segundo” e “em função de” uma ideologia, que se quer manter e reforçar), podem germinar, por processos criativos semelhantes: transformadores, deformadores, paródicos, imaginários e estilos comparáveis.

A diferença é que, em Raul Pompéia, o plano do sonho aparece nitidamente separado do real ("Sonhei em regra.[...] A sineta, tocando o despertar, livro-me da angústia. Cinco horas da manhã”); enquanto, nos Chants, esse é o plano habitual da narrativa, onírica do começo ao fim. Mas não é apenas no sonho que os acontecimentos reais podem tomar um caráter fantasmático. 
Mário de Andrade, em seu estudo sobre O Ateneu, observa que: “a raridade vibrante das comparações, o ritmo opulento atingem o abuso e algumas vezes o mau gosto” (p. 181). Essa observação é quase idêntica às que fizeram os primeiros críticos de Lautreámont, sobre a “riqueza hiperbólica” e o “mau gosto”, de certas passagens dos Chants. Também é interessante notar que Mário de Andrade aponta, em Raul Pompéia, um abuso do “como” comparativo, “mero cacoete de retórica” e “volúpia da brilhação”. Entretanto, acrescenta: "Mas é incontestável que raramente o espírito metafórico alcançou tais lucidações, que chegam a convencer muitas vezes pelo propósito raro da invenção” (p. 182).

Muitas semelhanças temáticas e estilísticas, nos dois autores, decorrem de leituras comuns. Fora do âmbito francês, há uma referência comum aos dois autores: Edgar Allan Poe; mas essa referência também passa pela França, via Baudelaire.

A obra literária nasce sempre de um diálogo com o grande texto cultural preexistente, e de uma dialética entre esse texto e a realidade, experimentada e observada. No caso de Lautréamont e Raul Pompéia, a vivência de certo discurso, mentiroso com relação a certa realidade, levou os dois autores a um pessimismo radical. O pessimismo desembocou em crítica, e é essa crítica que constitui o valor e a função maiores dessas duas obras.

A diferença qualitativa da escritura, do clichê do poemeto à originalidade do escritor se presta, ainda uma vez, a evidenciar aquela dialética do geral e do particular, do antigo e do novo, que produz a grande obra literária. Mas, segundo a crítica, o que interessa nessa aproximação é a semelhança da mensagem entre os dois escritores, apesar do reconhecimento da superioridade literária de Pompéia.

Para o surgimento do novo é necessária a tensão particular de determinados momentos históricos em que, da caducidade de uma cultura, emergem os traços de outra. Mas ainda mais: quando a contradição é vivida também espacialmente, num confronto entre mundo velho e novo, essa dialética é acelerada.

Segundo Perrone (1988), Lautréamont e Raul Pompéia agem como autênticos anarquistas. Justifica que contra os ataques maciços de discurso edificante, retrucam com armas que são igualmente linguageiras, pois ambos devoram a cultura européia e a devolvem 
transformada, rejeitando determinados aspectos, assimilando outros que, digeridos, já não são mais os mesmos.

Discordo da generalização crítica feita pela autora. Há de se considerar que um escritor constrói sua poética ao longo de muito tempo e esforço contínuo, mesmo com o talento inato de Pompéia. Ainda que os escritores de seu tempo sofressem influências e passassem por diversas experimentações até que chegassem ao objetivo a que se propunham. Exercem, assim, a função específica da literatura como trabalho de linguagem. Porque a função da literatura não é acertar as idéias, colocá-las nos devidos lugares, indicar o bom caminho e a boa conduta, porque os meios só são eficazes no uso pleno de seus recursos específicos, mas apontar criticamente, por um deslocamento de linguagem, as impropriedades do discurso dominante. Isto porque a literatura não é debate de idéias por meio da linguagem, mas embate de idéias na linguagem; que só indiretamente pode influir nos debates ideológicos e contribuir para a mudança de uma realidade insatisfatória.

Nesse sentido, ainda segundo (PERRONE, 1988, p.15-40), a literatura é sempre linguagem deslocada, linguagem fora de lugar. E é nesse deslocamento que ela cumpre sua função sutil, quase imponderável se quisermos avaliar-lhe a ação efetiva no conjunto das mutações sociais, mas obstinada e indispensável nessa tarefa que é a sua: a de revolver criticamente a linguagem, quando esta já se instalou como véu ideológico; quando esta já se institucionalizou, como fala oficial da verdade e forma legal do belo.

\subsection{Prosa Poética}

Segundo Brayner (1979), Pompéia assimilou dos irmãos Goncourt o estilo concreto, no qual o uso de vocabulário inusitado reflete a conquista de espaço pitoresco, em que se percebe a sonoridade e a fluidez da linguagem como instrumento da poeticidade. Os Goncourt foram muito combatidos. Entretanto os inovadores tiveram sua influência no que diz respeito a determinados artifícios estruturais, como a fragmentação formal, os ritmos internos da frase, o gosto pela 
justaposição frasal ou cênica, a preferência por pequenas unidades, a fuga dos instantes de clímax na construção ficcional, mas, sobretudo, a tendência formal pela miniatura literária.

Capaz (2001, p.161) afirma que quando os primeiros poemas em prosa de Pompéia vêm à luz, eles fogem à vertente metafísica das Canções, aproximando-se muito dos Petits Poèmes em Prose, de Baudelaire, por seu formato e preocupações temáticas. Em todos, há um capricho de linguagem surpreendente, a par da nota pessimista que é quase sempre, a base mais profunda do seu pensamento.

O miniaturismo, em Pompéia, aparece com a publicação em jornais das canções microscópicas, às quais deu o nome final de Canções sem metro. Nesses textos, a narrativa se reduz ao mínimo, sendo fragmentada a partir de uma perspectiva psicológica e não espacial. Há um deslocamento tanto na concepção descritiva, física e psicológica, quanto no foco narrativo. A ambiência é a realidade percebida, em vez de determinada. Essa tendência vai se acentuando até chegar ao simbolismo, passando pelo impressionismo subjetivista, a exemplo de $O$ Ateneu. Para Pompéia, a composição material dos objetos do mundo exterior não tem existência independente. Ela depende das condições intelectuais e afetivas de seus intérpretes, narrador ou personagem.

As discussões em torno do poema em prosa, sua caracterização e possibilidade como gênero híbrido são provocações para que o texto se liberte de seus quadros tradicionais. O deslocamento da fabulação, em beneficio de um narrador, e a busca de uma nova linguagem ganham destaque dentro de um universo temático fortemente organizado no seu conjunto de relações, a exemplo das canções de Pompéia. Como se percebe a crítica sempre deu muita atenção a $O$ Ateneu, mas a recepção crítica em relação à sua prosa poética é reduzida e uma das razões que contribuíram para a escolha deste tema para estudo. Ressalto a importância da publicação de toda sua obra, em dez volumes, organizada por Afrânio Coutinho, com a assistência de Eduardo Coutinho.

A melhor crítica sobre as Canções sem metro foi escrita por Ivo (1963), além dos artigos que citamos de Therezinha Bartholo e, mais recentemente, por Heitor Martins em artigo no jornal O Estado de São Paulo, com o título As canções sem metro, cosmologia do malogro. Ainda, Lopes e Silva (2004) em seu ensaio: A Filosofia e a História em Pompéia. 
Como sabemos, o final do século XIX assistiu a variadas criações de formas literárias, algumas de breve duração, que vão desde a prosa poética ao poema e ao verso livre, obtendo uma quantidade surpreendente de execuções intermediárias. Mas o que vem caracterizar sobremaneira o poema em prosa e que surge como um dos seus traços distintos e conflitantes de se constituir um gênero híbrido e, ao mesmo tempo, negar as formas existentes em nome da liberdade criativa: busca antinômica de uma síntese entre destruição e criação, ou seja, a retomada de uma tensão eterna nas formas da arte, entre a ordem e a liberdade. Segundo Brayner (1979), em um primeiro momento pensavam os simbolistas franceses que a diferença existente entre a prosa e o verso fosse apenas de grau e não de natureza; isto os levaria a afirmar ser possível a passagem de um para outro por meio de transições insensíveis. Pouco a pouco foram percebendo, através da experiência poética, que se encaminhavam para um beco sem saída, pois que a noção de verso não fora suficientemente compreendida. Antes de mais nada, o verso é uma unidade tanto auditiva quanto visual, qualquer que seja o tipo de metro usado. Quanto a prosa, sua unidade e a frase. Os simbolistas, nesta tentativa de isolar a poesia da versificação, tentaram fazer coincidir a unidade formal e a unidade lógica. Entretanto, estas unidades lógicas do poema em prosa tendem a se relacionar, menos de forma lógica do que rítmica e poética. Assim, as diferenças básicas não são de grau e sim de natureza.

Assim, a narrativa cada vez mais vai subjetivar os impulsos contemporâneas das pesquisas simbolistas no terreno da prosa. As variantes sucedem-se desde as tentativas mais formais de Aloysius Bertrand aos sonhos iluminados e visionários de Rimbaud. Tem-se, por um lado, os artistas que buscam encontrar as leis de organização de uma forma não muito distanciada do poema em verso, com sua ordem cíclica de simetrias métricas e sonoras; por outro lado, os poetas revolucionários caminham para um projeto poético mais livre e criativo, na expectativa de violentar a ordem estabelecida e, através da superação, atingir a conquista de um mundo novo, surpreendente, irracional. Entretanto, a anarquia não constitui a dominante dessa revolução poética. Instala-se uma ordem em que as palavras formam uma espécie de constelações de imagens, criando uma atmosfera interior em síntese altamente simbólica e metafórica. Tudo isso pode ser percebido na leitura das canções pompeianas, conforme demonstraremos posteriormente. Em seqüência dos pressupostos teóricos que estão abrindo caminho para a compreensão e possibilidades de argumentação sobre o hibridismo da prosa poética ligada ao jornalismo literário de Pompéia, é pertinente ainda discutir os conceitos e 
cânones vigentes sobre prosa literária e poesia e depois sobre a prosa poética e sua problematização.

Jean Cohen, no seu livro Estrutura da Linguagem Poética (1981), acrescenta que "no plano semântico, observa-se igual desvio, visto que a linguagem poética é mais plurissignificativa que a linguagem literária prosaica e possui um grau superior de conotação", adiantando ainda que "o verso é, portanto, um desvio ou uma ruptura em relação às regras do paralelismo do som e do sentido que reina em toda a prosa".

Sobre este assunto questionamos as possíveis diferenças no plano de expressão e ao nível fônico. Para Mário Fiúza, que, aliás, parafraseia o pensamento de Weirich, Die Semantik der Methaper (1967), e de Todorov, Literature e Signification (1967), a mensagem poética "é geralmente ambígua e está no caminho entre o inteligível e o ininteligível", enquanto ao nível fônico se observa que as "aliterações, a rima, a acentuação, os silêncios, os espaços em branco contribuem, por um lado, para o aumento da musicalidade, e por outro lado, ocasionam um obscurecimento da mensagem poética".

Entendemos aqui obscurecimento por estranhamento e dificuldade de leitura levantada por esses signos. No plano semântico os autores acima citados dizem que no discurso poético ainda encontramos ainda um maior número de "impertinências semânticas" do que na prosa. Para entendermos o que é impertinência devemos considerar o seu contrário, ou seja, a pertinência semântica que é aquela que existe numa frase quando esta estiver correta segundo as regras sintáticas e o significado.

Todavia, é no plano paradigmático que se percebe a diferença fundamental, segundo Mário Fiúza, entre poesia e prosa literária. De acordo com aquele estudioso português que novamente parafraseia Weinrich e Todorov "a metáfora em sentido lato é a característica fundamental da linguagem poética".

Vamos partir do fato já enunciado por vários estudiosos que na literatura contemporânea se tem atenuado a oposição entre prosa literária e poesia. Na verdade, para citar exemplos, basta lermos um romance de Vergílio Ferreira, Para Sempre (1983), ou de Jorge Amado, Mar Morto (1936), ambas narrativas em língua portuguesa, para compreendermos que os 
pressupostos expressivos, fônicos, metafóricos e mesmo ritmáticos, mencionados como característica da poesia, podem também estar contidos na narrativa da prosa.

Depois desta afirmação podemos entrar no campo da prosa poética e dizer já que, a partir do final do século XIX, essa forma híbrida pode ser encontrada. A prosa literária e a poesia coexistem como prosa poética ou poemas em prosa em vários enunciados textuais. Comprovamos com as Canções sem metro, de Pompéia.

Para Karl Vossler, Filosofia da Linguagem (1947), por exemplo, “a poesia e a prosa atraem-se reciprocamente de modo que embora às vezes se afastem uma da outra, canalizando suas águas separadamente como dois braços de um rio, logo voltam sempre a fortalecer-se mutuamente em novas confluências e novos traçados". Portanto, percebe-se que essa dicotomia prosa/poesia que era mais tênue no passado clássico e medieval e que se acentuou a partir do renascimento até ao realismo, mas que começou a diluir-se a partir do século XIX, há muito tende a desaparecer, a perder as suas fronteiras.

Recorrendo ainda a Todorov e Cohen podemos dizer que há três variedades de texto poético: a prosa poética, prosa versificada e a poesia integral. Dizem, ainda, que a prosa poética, também denominada poema em prosa ou poema semântico, se identifica pela existência de caracteres poéticos no plano do conteúdo, deixando os outros planos inexplorados. Assim, pretendemos contemplar também os planos fônicos, ritmáticos e metafóricos, entre outros, na análise do corpus desta pesquisa. Segundo, Mário Fiúza, p181, os críticos acima citados afirmam que é na prosa poética que se inclui o verso livre, aquele que não obedece a qualquer esquema métrico e não recorre à rima. Todorov, por exemplo, não vê qualquer diferença entre verso livre e prosa poética, enquanto Jean Cohen afirma que a existência de silêncios ou espaços em branco no verso livre é a única característica que permite distinguir da prosa poética.

Na literatura brasileira predomina a vertente mais artística ou cíclica do poema em prosa, com variações individuais de inflexão, tonalidade e atitude metafísica. As revoltas radicais de recusa das categorias temporais e lógicas, com predominância de uma estética da descontinuidade e da visão iluminada não surgem com freqüência. Na passagem do século, as oscilações entre polaridades não chegam à radicalização da magia de uma nova língua 
poética, perseguidas por Rimbaud ou Lautréamont, Brayner (1979). Entretanto, as conquistas de um espaço subjetivo mais amplo foram importantes para os destinos da ficção e da modernidade brasileira.

A concepção inicial dos textos de Raul Pompéia já apresenta, sob o domínio de características impressionistas, a preocupação das alianças harmoniosas e subjetivas entre representação e sugestão. O autor deu-lhes a princípio o subtítulo identificador de microscópica e trazem em essência o germe do estilo poemático em que estarão narradas inúmeras cenas de $O$ Ateneu e também as suas Canções sem metro, publicadas em jornais, mas longamente buriladas para uma futura edição. Essa só se concretizaria depois de sua morte e sem as ilustrações que faziam parte dos textos que o autor selecionara, em constante processo de burilamento, com o intuito de uma edição definitiva. Raul Pompéia, que em O Ateneu se revelaria um curioso miniaturista, nas Canções sem metro amplia o espectro de suas preocupações, numa busca incessante de infinito, de uma cosmologia.

A epígrafe do texto inicial das Canções sem metro, publicada pelos amigos do autor, em 1900, e índice de sua filiação estética. Trata-se do famoso poema de Baudelaire, “Correspondences” contido em sua obra, Les Fleurs du Mal. A estrutura das Canções sem metro é bastante variável. Além da tendência lírica expressa por imagens nucleares, soma-se o caráter cíclico das composições, em que são retomados os motivos iniciais como chave final. Também a forma alegórica oferece ao autor as possibilidades de movimentação subjetiva, quando se repartem as vozes da discussão. Uma tonalidade moralizante, realizada sob a forma de aforismos, acrescenta-lhes um aspecto de intemporalidade, às vezes marcado pela ironia originária de um pensamento social. Veja-se, por exemplo, a canções constantes da terceira parte, intitulada “O Ventre”, V. IV, p. 61. Já no século XIX, Baudelaire havia elaborado, na teoria e na prática, o poema em prosa: "Qual de nós não sonhou com o milagre de uma prosa poética, musical sem ritmo e sem rima, bastante maleável e rica de contrastes para se adaptar aos movimentos líricos da alma? (...) É, sobretudo, da frequentação das grandes cidades, é do cruzamento de suas inúmeras relações que nasce este ideal obsessivo".

Como gênero literário, a prosa poética é híbrida, ou seja, poesia em forma prosa. A prosa poética pode apresentar-se composta de mitos, de contos, provérbios, clichês, anotações, aforismos, epigramas, crítica, anedota, citações, reflexões, digressões metafísicas. Identificação 
com o modernismo: simplicidade, anti-parnasianismo, metalinguagem crítica, surrealismo, humor, humor negro, trocadilho, a paródia.

A prosa poética caracteriza-se pela estética do fragmento e constitui a desmistificação do poético em intensa rede intertextual, como se percebe com a presença de várias artes. Creio que a produção de um poeta implica uma incursão consciente ao nível simbólico. Mas há aqueles que compartilham essa criação literária com a reflexão filosófica ou a presença de outros campos da arte. Essa produção híbrida se transforma em uma espécie de lente sem a qual o autor não consegue mais enxergar o que existe diluído no universo que percebe e como o texto só se concretiza completamente com o leitor, o escritor acaba por universalizar sua percepção de mundo. Assim, poetizar passa a significar pensar, refletir implica imaginar e visualizar, revolver a linguagem, penetrando em seu jogo de acolhimento simultâneo do perceber, do expressar e do questionar o cosmos a exemplo dos textos de Pompéia.

Na concepção poética de Mário Quintana, a lírica constitui-se de metalinguagem: reflexão sobre a poesia, a literatura em geral, o ato de ler. Portanto, lembremos as suas afirmações sobre o tema: poesia não é teorema, mas algo instintivo, como um grito carregado de emoção. O poeta é que traz, humildemente, a sua própria verdade. Quanto mais individual, mais universal é o poeta. A poesia pode vir de uma frase, de uma imagem, nas mais inusitadas ocasiões. A poesia exige um trabalho de corte, de depuração, mas sem exageros, pois poema não é um esquema. A poesia exige luta, a exemplo do episódio bíblico, em que Jacó luta com um anjo. Só pode fazer poema em versos livres quem aprendeu, antes, a fazer sonetos clássicos. Não existem influências, mas confluências: o poeta deve ler quem se parece com ele.

De acordo com Genette (1982), não se trata de revelar um hipotexto escondido e sua significação, mas de mostrar a natureza dessa relação e de analisá-la nos seus desdobramentos. Com efeito, o essencial não é a proveniência dos materiais de uma obra, mas sua construção, que pode dar-lhe um valor e uma significação diferentes. Esta afirmativa, não tira o mérito da crítica genética, um dos recursos teóricos desta pesquisa, pois ao analisar a prosa poética de Raul Pompéia, estabelecemos um diálogo, entre as versões publicadas nos periódicos e em livro, posteriormente. 
Logo depois de sua chegada ao Rio, Pompéia enceta a publicação de muitos de seus textos do Recife, nas páginas da Gazeta da Tarde. Juntamente com Alma morta, vem à luz a segunda série de suas Canções sem metro, que davam seguimento ao trabalho iniciado, em São Paulo. Ainda, segundo Capaz (2001, p. 88), as Canções sem metro foram publicadas entre 17 de dezembro de 1885 e 29 de janeiro de 1886. Elas sofreriam até 1889 sensíveis modificações de forma, além da inclusão de uma ou duas canções e da exclusão de outras tantas. Em linhas gerais, entretanto, pode-se dizer que o trabalho então publicado estava bastante próximo do que se pode chamar de definitivo, conforme grafou Pompéia em sua seleção que seria publicada após sua morte.

A prosa poética, na linha anteriormente praticada por José de Alencar, já era utilizada com freqüência em seus contos e crônicas, do mesmo modo que o seria mais tarde em O Ateneu. Capaz (2001) acrescenta que em razão de sua reconhecida dificuldade com a métrica e com a rima, numa época em que o verso livre era apenas objeto de experimentação de alguns poucos inovadores, não achou assim melhor maneira de expressar-se poeticamente que através do poema em prosa, que nada mais é que a prosa poética acondicionada numa forma bastante complacente.

O mesmo crítico, Capaz (2001, p.89), afirma em seu livro Raul Pompéia: biografia, que Pompéia submete o seu texto a um intenso trabalho de cinzelamento de alguns poemas, nessa busca da expressão ideal, chegando a ter duas ou três versões antes da forma definitiva. Há neles o mesmo pessimismo irremissível e a mesma visão desencantada do mundo, concentrados numa prosa que vai pouco a pouco ganhando densidade do mundo, na medida em que se descarnava e ganhava delineamentos conjeturais.

Questiona-se o motivo de as Canções sem metro, que tomou tanto tempo de Raul Pompéia, não ter tido sucesso, ao contrário de $O$ Ateneu. Por que razão foi recebida tão friamente pela crítica e pelos leitores, a ponto de nunca ter sido reeditada em quase 60 anos, e estar hoje em terceira edição. A resposta pode ser porque o leitor comum não se sensibiliza com a literatura pessimista, que não fala de alegria e do amor, das belezas do mundo e da vida. E a nota amorosa é a grande ausente nas Canções. Ali a visão do mundo é a mesma de Alma morta, desencantada e triste, sem concessão ao humor, que mascara a miséria e sorri às tristezas, e que muitas vezes pode atrair o leitor para obras desse gênero. 
Pompéia quis fazer uma obra orgânica, um conjunto de canções que representasse uma visão totalizante do universo, lírica e filosófica ao mesmo tempo, do ponto de vista do homem pessimista do final do século XIX, descrente das conquistas da ciência e confuso diante do imenso abismo de interrogações que o desafiavam. É semelhante ao canto tristemente belo de Alma morta que permeia os seus poemas, em que não aparece nenhuma ode à alegria. Quando muito, nas páginas finais, faísca um canto em louvor às revoluções sociais, numa espécie de convocação à luta contra as injustiças, prenúncio das idéias que o empolgariam, nas futuras campanhas pela consolidação da república. Então, o autor passou a falar de um ideário nacionalista, visualizado de forma ainda um pouco vaga. Por duas ou três vezes, sobretudo na versão jornalística, percebe-se um ponto de esperança ou uma saudação ao sol que ele chama de divindade.

Na primeira parte do livro, ao qual deu o título de Vibrações, estão os poemas publicados em São Paulo, entre 1883 e 1884, no Jornal do Comércio e no Diário Mercantil, que na edição definitiva viriam precedidos por uma quadra do poema, Correspondances, de Baudelaire.

Para um sensorial como ele, a vibração era a própria vida, que lhe chegava através dos sentidos, principalmente da visão: "Vibra o abismo etéreo à música das esferas; vibra a convulsão do verme, no segredo subterrâneo dos túmulos. Vive a luz, vive o perfume, vive o som, vive a putrefação. Vivem, à semelhança, os ânimos”.

Nas vibrações estão as cores da natureza identificadas com os sentimentos que lhes correspondem. O verde se identifica com a esperança, o amarelo é o desespero da mulher abandonada em seu leito de morte, depois de uma vida de devassidão e de fausto, ao tempo em que se cobria com jóias de ouro. O autor visualiza o azul no ciúme da mulher abandonada a olhar tristemente o infinito do céu. Já o roxo é a tristeza, "tinta tomada à palheta do ocaso e às flores da morte” - as violetas. E a pobre mãe que olha o potente afogueado em sangue, só se vê nele o vermelho da guerra, para onde seguiu o filho na viagem sem volta, ao contrário do branco, que é a paz que se segue ao conflito, o branco das neblinas que cobrem os campos, o branco da "estrela plácida das tardes” e também da lua que vai “pelos caminhos, semeando a difusão suavíssima da paz”. A morte é a cor negra que nos envolve mesmo nos mais claros dos dias: - “As escuras noites do espírito”. Bem diversa do rosa, a cor do amor, que se desenha no “sorrir das virgens”, no “adorável pudor” e na "primeira luz da manhã”. 
Além das cores da natureza, Pompéia encontra espaço em sua paleta para as cores que moram nas almas torturadas pela brutalidade, nos seres vencidos pelo cansaço, mutilados pela escravidão, que votam um ódio mortal ao senhor que tolhe sua liberdade. Neles sobrevive o incolor nos sentimentos, cor que não se define. E que dizer da cor sem cor do tédio, que habita as criaturas cansadas de viver?

"Há também nas almas o incolor diáfano do vidro.

Dinheiro, amor, honraria, sucesso, nada me falta. O programa das ambições tracei, realizei. Tive a meu serviço a inteligência estudiosa do Ocidente e a sensualidade amestrada do Levante. Tive por mim as mulheres como deusas e os homens como cães. Nada me falta e disto padeço. Todos dizem: aspiração! E eu não aspiro. Todos sentem a música do universo e a harmonia colorida dos aspectos. Para mim só, vítima da saciedade! tudo é vazio, escancarado, nulo como um bocejo. E os dias passam, que vou contando lento, lento, torturado pela implacável cor de vidro que me persegue."

Raul Pompéia, que em O Ateneu se revelaria um curioso miniaturista, nas Canções sem metro amplia o espectro de suas preocupações, numa busca incessante de infinito. O produto final de seu trabalho por mais de uma década é a construção de um novo gênero, tão bem trabalhado que se torna uma verdadeira escritura artística.

A partir das historietas que formam o capítulo das Vibrações as motivações metafísicas se aprofundam. É o que dizem os títulos dos últimos capítulos: Vaidades e Infinito. O irmão intelectual de Schopenhauer e de Leopardi olha o universo à sua volta e reconhece-se esmagado por sua grandeza.

Nesse universo de uma grandeza estonteadora, em que só há interrogações e dúvidas, nada explica o absurdo da existência, sequer as exaustivas pesquisas das ciências em sua ânsia de devassar o mistério.No mundo cercado de interrogações, só o trabalho artístico e as lutas em favor da liberdade podem servir de refúgio ao ser humano, trazendo-lhe satisfação e consolo. 
Contra a realidade, "um círculo de trevas”, a arte se eleva como a embriaguez do belo consolador que, ao contrário da embriaguez efêmera da sensualidade, "como farol de Leandro, imortal e culminante, domina impávida o naufragar das eras”, papel desempenhado também pelos lutadores da liberdade, que lhe merecem três poemas. A revolução sempre se apresenta a Pompéia como um sol afugentando as trevas da opressão, ambiciosas e sanguinárias, à semelhança de Macbeth, de Shakespeare.

A não ser por essas duas válvulas de escape, não há vislumbre de saída ante o enigma do infinito. Infinitos são os astros, que no rumor do espaço zombam das agitações humanas. Infinitas são as lembranças e as cinzas dos antepassados, legado de que nos servimos como um repasto em honra dos vindouros. Infinito é o vulcão extinto que se abre para as profundezas da terra, mostrando-nos sua “imensa boca torcida na expressão de feroz agonia”. Infinita é Atlântida, continente perdido sob uma campa amplíssima, cujo mistério só os monstros marinhos podem desvendar.

Frente a tantas interrogações, Pompéia não procura consolo nas religiões ou nas crenças. Como um deus pagão, contenta-se com o sol, o adorado sol criador das cores e dos dias. E pergunta: "Por que buscar mais alto a divindade?!"

No orgulhoso século que imaginou achar o segredo de todas as coisas, o poeta chega ao fim do seu poema cansado e de mãos vazias. E o fecha com um canto desesperançado mas de extrema beleza.

Nas Canções sem metro, obra lírica de vôos metafísicos, que procura exprimir o inexprimível, registrando sua visão de mundo, Pompéia levou seus recursos de expressão ao máximo de contenção e à mais extrema economia de linguagem, num vocabulário e num tom que às vezes se excedem em grandiloqüência e palavras talhadas em mármore. À medida que corrigia e limava os poemas, adjetivos são substituídos, vocábulos são podados implacavelmente, desprezando-se os estereótipos estilísticos já saturados pelo uso comum. Na maioria dos poemas, publicados em livro, pôs epígrafes relacionados com os temas enfocados, de autores e livros os mais diversos, como Baudelaire, Leopardi, Shakespeare, Molière e Proudhon. 
Obra de difícil classificação, Manoel Bandeira colocou algumas das canções em sua antologia de poetas parnasianos; Andrade Murici, em seu longo trabalho sobre o movimento simbolista, no Brasil, revela até que ponto os seus epígonos lhe eram afeiçoados. O certo é que, como os principais poetas do simbolismo brasileiro de sua geração, Pompéia é decadentista pelo pensamento e pela inspiração, a despeito das preocupações formais que o aproxima dos parnasianos, do que discordamos. Acreditamos que ele buscou a criação de uma nova forma híbrida, a prosa poética de suas canções. Esse exercício foi desenvolvido junto à imprensa periódica, onde as suas canções foram primeiramente publicadas. Assim, além de autor, ele tornou-se também receptor e como leitor crítico que era, pôde continuar a burilar seus textos até conseguir a forma sem metro que julgou definitiva.

Logo que publicadas na imprensa, Alma morta e as Canções sem metro chamaram a atenção dos intelectuais e dos leitores em geral, pelo que tinham de inovadoras: ali despontava um jovem escritor, com talento filosófico, que se alçava acima dos seus pares, trazendo para o sol dos trópicos o pessimismo europeu vigente e uma espécie de inspiração decadente, de alquimia puríssima, urdidos com palavras trabalhadas a fogo e calibradas em balanças de extrema acuidade. Então, Pompéia era observado e apontado nas rodas da Rua do Ouvidor, nas livrarias e nas palestras com amigos intelectuais. Seus ditos espirituosos eram repetidos pelos colegas da imprensa. Alcindo Guanabara, no fecho de uma crônica, não deixa passar a oportunidade de revelar-lhe o humor:

“Ontem, no Polytheama, passa uma flutuante e um velho volta-se para examiná-la.

O Pompéia com ar de filósofo:

— Eis um homem que se volta, a fim de olhar para o passado” (GAZETA DA TARDE, 17.05.1886).

Daí por diante, passaria a circular nos meios intelectuais como um dos seus membros mais espirituosos e cultos. Era visto nas redações, cafés e livrarias em conversas sobre os acontecimentos da Corte ou sobre os lançamentos literários mais recentes, principalmente ao lado de Capistrano de Abreu, Araripe Júnior e Rodrigo Octávio, os amigos mais chegados. 
Alguns fragmentos das canções parecem extraídos de periódicos ilustrados, destinados ao grande público e se referem à temática metafísica, sempre recorrente em Pompéia. Da caça, da vida dos animais e insetos, às profissões, às experiências científicas. A maioria das imagens provém, de fato, de romances-folhetins do século XIX que costumam tratar os grandes temas românticos em cenários dramáticos e por meio de diálogos permeados pela crítica moral cristã.

O quarto volume da coleção das obras completa de Raul Pompéia, citada anteriormente, enfeixa as “Canções sem Metro", a série de pequenas crônicas ou miniaturas, ou melhor, poemas em prosa, que escreveu desde quando, em São Paulo, cursava a Faculdade de Direito. Os testemunhos, adiante transcritos, de Rodrigo Otávio e Coelho neto registram o fato. Todavia, refere Rodrigo Otávio o ano de 1884, como aquele em que o colega se entregou a essa produção. Pela nossa pesquisa e coleta de material, ele começou, aos vinte anos, em 1883, a publicar as “canções” no Jornal do Comércio, de São Paulo, de cuja redação fazia parte, figurando no cabeçalho do jornal ao lado de Gaspar da Silva é o que prova o documento aqui estampado de seu próprio punho. Reproduziu dez delas em 1888 e 1889, em A Galeria Ilustrada de Curitiba, Paraná. A partir de 1885, deu-lhes publicação no Rio de janeiro, nos periódicos: Gazeta da Tarde, Treze de Maio, A Semana, A Rua, e, ainda em São Paulo, em A Província e O Estado de São Paulo, e também no Diário de Minas, de Juiz de Fora, e A Província do Espírito Santo.

A Galeria Ilustrada, editada pela Litografia do Comércio, de Curitiba, cujo primeiro número é de 20 de novembro de 1888, publicou, como disse, uma série de dez “canções”, com desenhos e assinaturas do punho do artista. É interessante assinalar o que a revista informa no primeiro número: "Possuímos uma lindíssima dezena de contos de Raul Pompéia, acompanhados dos respectivos desenhos". A referência a "contos" é significativa, pelo que veremos adiante.

O escritor dava muita importância a esses trabalhos que produziu e publicou nos periódicos da época. Falecido, um seu amigo, o jornalista João Andréa, a pedido da genitora de Raul, editou, em 1900, um pequeno volume reunindo um grupo de “canções” certamente selecionado e organizado pelo Autor e deixado pronto, pois se sabe que ele pretendia publicálas. Muitas outras, porém, ficaram dispersas nos jornais e revistas. 
Que Pompéia intentara lançar em livro as “canções”, não há dúvida, como se pode depreender da folha escrita, com sua letra e assinatura, levando a seguinte declaração:

\author{
Canções Sem Metro \\ Esboçadas em 1883, algumas dessas publicadas em diversos jornais.
}

Forma definitiva

Raul Pompéia

Costumava ele trabalhar intensamente as suas canções, introduzindo modificações no texto ou nos títulos, de modo que elas aparecem nos periódicos, muitas vezes sob formas diferentes ou variantes, fato já assinalado por Teresinha Bartholo. Aqui se reproduzem todas as selecionadas, com vistas a estudos comparativos, estilísticos e técnicos sobre o autor.

O volume IV da coleção das obras de Pompéia organizada por Coutinho é dividido em duas partes: na primeira, são incluídas as canções da coletânea de João Andréa; na segunda, intitulada “Outras Canções Sem Metro”, as que nos foi dado localizar no jornal “A gazeta de tarde”, de janeiro de 1886.

Ao desincumbir-se da tarefa de editar as “canções”, conforme desejo da mãe do escritor, o jornalista João Andréa, não desejando, por modéstia, prefaciar o volume, escreveu, em folha solta anexada ao plaquete, a nota abaixo:

12 de abril

Esta data, que é a do aniversário natalício do Raul Pompéia, pareceu-me a melhor para dar publicidade. As Canções Sem Metro do glorioso artista.

Desempenhando essa missão que me foi delegada pela veneranda mãe do inesquecível Raul, desvaneceme o requinte de escrúpulo que fiz presidir à fiel reprodução dos originais do impecável autor do Ateneu, tendo nesse trabalho o valioso concurso de Américo Moreira e Colatino Barroso. 
Abroquelado pois contra a possível suspeita de uma temerária colaboração na obra de Raul Pompéia, assino esta folha, assim destacada, para que nem mesmo se dê a intromissão do nome de um amigo neste livro de arte. João Andréa

O livro apareceu com a seguinte folha de rosto: Raul Pompéia. Canções sem metro.Rio de Janeiro:Tipografia.Aldina, Rua da Assembléia, 96,1900.

A capa não traz a indicação da data. O folheto tem 77 ff + índice

Em 1926, Rodrigo Otávio, antigo condiscípulo e amigo de Pompéia, transcreveu-as na Revista da Academia Brasileira de Letras. Ano XVII, n. 49, 50, 51, 52, juntando-lhes uma nota introdutória e um artigo de Coelho Neto.

Depois da $1^{\mathrm{a}}$ edição em livro, houve as seguintes publicações das Canções sem metro: PONTES, Elói - Raul Pompéia - Canções sem metro - Coleção Vida Literária, dirigida por Elói Pontes. Rio de Janeiro, Editora Casa Mandarino, s/d.

IVO, Ledo - O universo poético de Raul Pompéia (em apêndice:“Canções sem metro e textos esparsos”). Rio de Janeiro, Livraria São José, 1963.

O critério editorial da publicação de Canções sem metro (1982), traz a seguinte explicação:

1. A presente edição, quanto à primeira parte do volume, reproduz fielmente o texto lançado pela Tipologia Aldina, da responsabilidade de João Andréa.

Foi atualizada a ortografia e corrigidos poucos erros tipográficos óbvios. Respeitaram-se, todavia, algumas formas lingüísticas, comuns na época ou sobre as quais o autor oscilou, inclusive nas outras obras.

Exemplos: acoutamento, acoutas, açoutavam-se, cousa, dous, douda, doudamente, doudejantes, anoutecer, noutada, noute e noite, pousados, por outro lado, há cousa e coisa, noute e noite. Também o uso do apóstrofo em d’alva, d’água, d’arte, d’alma,d’oiro, foi respeitado, mas há também donde,d’onde e noutras. O ditongo ou predominou nas formas acima mencionadas, mas foi mantida a oscilação. 
2. Quanto às “canções” incluídas na segunda parte, foram respeitadas nas formas em que apareceram nos periódicos, procurando-se manter a coerência com as normas adotadas para a edição de 1900.

a) Foram recolhidas e publicadas, na segunda parte, as que não ofereciam qualquer dúvida sobre a autoria, isto é, as que levavam assinatura ou um pseudônimo conhecido, e o título de “Canções sem Metro” no jornal;

b) Reproduzem-se todas as versões, indicando-se as fontes e respeitando-se o texto, na forma em que aparecem;

c) Nos rodapés, ao final de cada “canção”, são indicadas as diversas fontes onde foram encontradas, seja sob roupagem igual ou variante. Todavia, durante nossa pesquisa percebemos que houve publicação em 1981, apesar da informação de que seu início seria o ano de 1983.

Seu iniciador foi o francês Aloysius Bertrand (1807-1841), no Gaspard de la Nuit (1842), e que já vinha escrevendo poemas em prosa a partir de 1827, ao lado de Maurice de Guérin, este desde 1835.

A idéia poética que deu começo ao gênero foi uma reação, em nome a liberdade, contra as regras rígidas do classicismo e a tirania formal, tendência que surgiu também em outras literaturas que não a francesa, sobretudo a inglesa, marcando o nascimento do romantismo. Entretanto, o grande valorizador do gênero foi Charles Baudelaire, com seus Petits Poèmes em Prose (1869), trabalhados desde 1855, de confessada influência de Bertrand. Ao autor de Les Fleurs du Mal o gênero deve a sua definitiva feição artística e sua voga entre escritores de todas as literaturas, com cultores da maior qualidade.

Suzanne Bernard estudou amplamente a forma, mostrando o caráter protéico do gênero, seu polimorfismo, seu modo inacabado e inorgânico, segundo a crítica, sua tendência a explorar regiões desconhecidas e insólitas, interditas, em busca de construir e organizar uma forma nova, um universo flexível e autônomo. Assinala ainda as relações entre o poema em prosa e a ambição metafísica.

Seu estudo põe em relevo a poética do gênero, acentuando outras características: a intemporalidade, a gratuidade, a brevidade, a densidade, a unidade, a síntese iluminadora, encantatória, tudo isso escrito segundo a maior economia de meios, em tom lírico e na maioria 
das vezes em primeira pessoa e em escrita artística. O êxito do poema em prosa deve-se ao encontro com os poetas simbolistas, preocupados com uma forma mais livre e como percebemos Pompéia foi quem lutou pela criação do gênero híbrido, no Brasil, trabalhando arduamente até conseguir burilar as suas canções.

Os primeiros poemas em prosa de Pompéia que então vêm à luz fogem à vertente metafísica das Canções, aproximando-se muito dos Petits Poèmes em Prose, de Baudelaire, por seu formato e preocupações temáticas. Em todos, há um capricho de linguagem surpreendente, a par da nota pessimista que é - como sempre - a base mais profunda do seu pensamento (CAPAZ, 2001, p.161).

Uma definição para estilo de época é o conjunto de características literárias que predomina em um período histórico, em determinado espaço geográfico e social.Cada obra literária possui, ao mesmo tempo, características que são especialmente do autor, a escolha de palavras, por exemplo, e características que não são apenas do autor, mas também de um conjunto de outros escritores.

As características apenas do autor compõem o seu estilo individual. Já as características comuns de um conjunto de autores podem compor um estilo de época, num contexto geográfico e social, durante certo tempo. É claro que, para definir um estilo de época, só levamos em consideração as características predominantes (as principais, para nós) do conjunto de obras de um período histórico (quer dizer, deixamos de lado as outras características). Embora as obras literárias apresentem diferenças entre si, se nós tentamos delimitar um estilo de época, não procuremos ressaltar as diferenças, e sim as semelhanças.

Quando muitas obras literárias apresentam um conjunto de características semelhantes, dentro de uma época e espaço determinados, então existe o chamado estilo de época. Por exemplo, houve um grande número de obras que seguiam os modelos artísticos gregos e romanos (conjunto de características semelhantes), na Europa (contexto geográfico e social), nos séculos XV e XVI (período histórico): foi o Renascimento (estilo de época). Essa divisão é feita para facilitar o estudo, mas não pode ser considerada com inflexibilidade, pois há o dialogismo intertextual. 
Do século XV até hoje, na península ibérica, muitas escolas literárias existiram: Renascimento, barroco, Arcadismo, Romantismo, Realismo, Simbolismo, entre outras.Há uma ligação entre estes diversos estilos: muitas vezes uma mesma característica, que era predominante em um estilo, passa a ser secundária em outro, sem desaparecer. Também não é absolutamente necessário que um estilo de época acabe por completo, para que surja um novo. Alguns existiram aproximadamente ao mesmo tempo, como o Simbolismo e o Realismo no Brasil. Isto porque não são compartimentos separados, incomunicáveis entre si.

Como já vimos, até uma mesma característica pode existir em dois estilos diferentes, sendo principal em um e secundária no outro. Além disso, o conjunto de obras literárias de um estilo de época tem sempre atrás de si os conjuntos de obras dos anteriores. Seja para aproveitar elementos literários dos estilos anteriores, seja para ser contra o aproveitamento destes elementos, de qualquer maneira, toda obra tem como referência as outras obras já existentes anteriormente, bem como as contemporâneas.

Qualquer estilo de época é um fenômeno localizado: é a expressão de um estado concreto da prática e da consciência literária, em determinado contexto histórico. E as escolas literárias têm, ao mesmo tempo, relação profunda com outras expressões da sociedade, artísticas ou não. Assim, na Europa e no Brasil, proliferaram diversas tendências literárias nas últimas décadas do século XIX.

Os traços acima sugerem o enquadramento e a inscrição apropriada das Canções sem metro de Pompéia no gênero do poema em prosa ou prosa poética. Não podia passar despercebida a inovação ao seu espírito inquieto, sedento de novidades literárias e sempre atualizado nas leituras do momento. Os poemas em prosa de Baudelaire são de 1869. Pompéia devia estar estudando e meditando o assunto antes de 1883, quando publicou as primeiras “canções”. O intervalo é perfeitamente normal da França para o Brasil, considerando-se ainda a idade de Pompéia, nascido em 1863. Por volta de 1880, é quando se pode situar a sua fase de maior absorção de leitura. Testemunham Rodrigo Otávio e Coelho neto que ele lia desbragadamente. E na época não era fácil escapar a Baudelaire, a figura genial que se coloca no ponto inicial de dois movimentos opostos, mas simultâneos e mutuamente influentes, o parnasianismo e o simbolismo, fenômeno dos mais curiosos da história literária ocidental, como põe em relevo Marcel Raymond. 
A alta posição de $O$ Ateneu e a sua enorme e justa fortuna crítica ofuscaram o restante da produção pompeiana, especialmente as Canções sem metro, que a meu ver constituem a sua verdadeira obra prima. Não se pode, de modo algum, menosprezar a importância dessa parte de sua obra, que o situa em relevo como pioneiro na renovação literária ligada ao simbolismo, só recentemente valorizada, em reação aos cânones clássicos ressuscitados pelo parnasianismo.

Ao adotar a forma do poema em prosa, Pompéia situa-se como um inovador, na linha modernizadora, inaugurada pelo simbolismo e integrada no impressionismo, que é, diga-se de passagem, uma inserção do simbolismo no realismo e uma preparação dos movimentos posteriores. Por isso Andrade Murici acertou, incluindo-o em seu monumental panorama do simbolismo. Aliás, esse é também o ponto de vista de outros estudiosos do escritor, como Ledo Ivo e Eugênio Gomes.

A análise das canções de Pompéia, à luz da estética do gênero dos poemas em prosa, realizada por Suzanne Bernard, acima aludida, confirma inteiramente que elas se inserem no tipo artístico que Baudelaire honrou. Em Pompéia são digressões de cunho lírico, aliadas a uma preocupação filosófica, utilizando uma escritura de elevado tom melódico, inteiriças, simbólicas, densas, breves.

A preocupação artesanal é evidente, o que não admira num escritor dotado de extremo zelo técnico e gosto apurado. Era Pompéia um escritor que se corrigia incansavelmente. A sua liberdade criadora e inventividade deveriam ter-se sentido às mil maravilhas num gênero livre, em que se vazou o seu lirismo moderno. Sente-se também nos poemas aquela "vontade organizadora”, a que se refere Suzanne Bernard, outro aspecto de seu gênero técnico. O gênero, conforme ainda a opinião da crítica, pode ser destruidor e anárquico, a princípio, para tornar-se construtor e artístico em seguida. Em Pompéia, observa-se esse fato com nitidez. O lirismo liberta-se mediante outro meio, a prosa poética ou o poema em prosa.

Ficou assinalado acima que a colaboração de Pompéia para a revista de Curitiba fora recebida e considerada na redação como contos. Aliás, essa definição coincide com a de diversas outras referências, aparecidas na imprensa da época e mesmo posterior, como vai documentado nas transcrições feitas no final do volume. Explica-se isso por que os pequenos textos encerram, constantemente, uma espécie de mote com uma pequena narrativa, de fundo simbólico, alusiva 
ao que está implícito no mote, ou exprimindo uma reflexão grave sobre a vida ou as coisas. Há sempre uma ilação de ordem filosófica, em meio a manifestações líricas, em que a melancolia é quase a regra, espécie de sombra ou luz crepuscular, de um espírito de rara sensibilidade, mas fronteiriço da neurose. Todavia, esclarecemos que Pompéia trabalhou na construção de um novo gênero híbrido e a maioria dos textos constitui-se de poemas em prosa.

De qualquer modo, a produção é de grande mérito literário, e só se explica a sua pouca repercussão pelo fato de que o êxito de $O$ Ateneu a tenha ofuscado ou colocado à margem. Vista por uma perspectiva moderna e relacionada ao contexto universal, ela deve ser considerada de alto valor e importância. Afinal constitui legítima expressão brasileira de um gênero original que merece reabilitação crítica, pois abriu caminho para uma renovação da literatura brasileira, tal como ocorreu na França, onde a poesia recebeu do gênero um saudável e definitivo impulso modernizador.

Infelizmente, ao contrário do que ocorreu na França, as correntes modernistas brasileiras não prestaram atenção às “canções” de Pompéia, talvez pela pouca divulgação que tinham e certamente pela mania antipassadista dos nossos chamados "futuristas", inimigos de tudo o que existiu antes deles. Não obstante, o poema em prosa foi largamente produzido pela literatura contemporânea.

É o que mostra Xavier Placer no pequeno, mas precioso livro que dedica ao assunto. Como precursor do gênero, aponta Vitoriano Palhares (1840-1890), autor de As noites da virgem (1868), em pleno sentimentalismo romântico. Mas foi sob a atmosfera simbolista que o gênero se implantou e consolidou.

E nessa fase, situam-se Raul Pompéia e Cruz e Sousa (1861-1898). O primeiro já vinha praticando o gênero desde 1881. De Cruz, dois são os livros de poemas em prosa: Missal (1893) e Evocações (1898). Mas a composição dos poemas que vieram a integrar Missal é posterior a 1890, o que confirma o pioneirismo entre nós de Pompéia no gênero, com as suas canções que são verdadeiras obras-primas.

Vale descrever aqui a comparação feita por Araripe Júnior entre os poemas em prosa de Pompéia e Cruz e Sousa: 
Cruz e Sousa ao qual já aludi no começo deste capítulo e que publicou dois livros, Missal e Broqueis, no intuito claro, manifesto, de acompanhar o nefelibatismo português. O Missal é um livro de prosa cadenciada, e, quanto à técnica, posto nas mesmas cordas, em que Raul Pompéia, aqui há tempos, ensaiou as "Canções sem metro". Entre as "Canções sem metro" e a obra do poeta catarineta, entretanto, entretanto, há uma grande diferença determinada desde logo pela raça e pelo temperamento de cada um. Raul Pompéia possui a acuidade dos psicólogos da nova geração e um espírito profundamente inclinado à filosofia sugestiva, de sorte que os seus escritos aparecem sempre impregnados disso a que Proudhon chamava "L'expression de l'Avenir": tendências tolstóinas para a organização do serviço de salvação da idéia. Cruz e Sousa, porém, anda em esfera muito diferente. De origem africana, como já disse, sem mescla de sangue branco ou indígena, todas as qualidades de sua raça surgem, no poeta, em interessante luta com o meio civilizado que é o produto da atividade cerebral de outras raças. A primeira conseqüência desse encontro é a sensação da "maravilha”. Segundo Araripe Junior,Cruz e Sousa é um maravilhado.Jornal: “A Semana.” Rio de Janeiro, 26 de maio 1894. Repr. O Movimento Literário do ano de 1893. Obra Crítica de Araripe Júnior. Rio de Janeiro, Casa de Rui Barbosa. 1958-1970 (O trecho está no vol. 3, p.146).

Xavier Placer cita diversos autores da fase modernista e pós-modernista que praticaram o gênero: Teodomiro Tostes, Álvaro Moreira, Augusto Meyer, Andrade Murici, Aníbal Machado, Carlos Drummond de Andrade, Jorge de Lima, Adelino Magalhães, Murilo Mendes, Vinícius de Morais, Mário Quintana, Ledo Ivo, Xavier Placer, Deolindo Tavares, Paulo Hecker Filho, Reinaldo Bairão, Paulo Mendes Campos, José Paulo Moreira da Fonseca, Osvaldino Marques, Paulo Armando, Homero Homem, Ferreira Gular, Emílio Carrera Guerra, Paulo Correia Lopes e outros. Seu livro contém excertos de cada um dos poetas referidos.

Esses testemunhos evidenciam a importância da forma e sua repercussão no Brasil, com a figura de Raul Pompéia como seu primeiro cultor e que lhe imprimiu o cunho de excelência artística.

Afrânio Coutinho, responsável pela publicação das Obras Completas, de Pompéia (1982) afirma que não poderia ter realizado o trabalho sem a preciosa colaboração de Juracy dos Santos Pereira, na pesquisa e coleta dos textos, devendo-lhe por isso o organizador da coleção e os estudiosos futuros do autor a maior gratidão. 
Segundo Rodrigo Otávio, a obra primorosa de Raul Pompéia, que tem o título, Canções sem metro, teve dois momentos de composição. A princípio o autor pensava apenas em escrever uns pequenos quadros - verde-esperança; azul-ciúme, e outros, que constituem, na obra definitiva, o primeiro capítulo denominado Vibrações.

Esses pequenos quadros foram escritos em São Paulo, em 1884, quando Pompéia cursava o quarto ano da Faculdade de Direito. Ele morava em uma casa da Rua do Chá, hoje Barão de Itapetininga, onde também por esse tempo vivia Coelho Neto. Para ilustrar o livrinho, em que pretendia publicar esses pequenos quadros, o autor, que era também um desenhista exímio, fez diversos desenhos coloridos.

No ano seguinte, houve por diversas causas um êxodo de estudantes de S. Paulo para o Recife. Relata que integraram o grupo e, por muitos meses, moraram juntos, em Caxangá, no Hotel Dona Maria à beira do Capiberibe.

Aí Raul resolveu ampliar o trabalho e, reunindo os primeiros quadros num capítulo só, ele compôs os demais capítulos, cujas epígrafes, todas rigorosamente inéditas como epígrafes, procurou com paciência beneditina.

Sua obra, assim como tantas outras, que o grande escritor produziu e entregou à imprensa diária, só muitos anos depois da morte do autor apareceu em livro. Uma feia e acanhada edição, devido à iniciativa de João Andréa, o infeliz jornalista, morto num desastre pouco tempo depois, e que fora amigo de Pompéia nos seus últimos anos de vida.

O livrinho, antes minguado folheto, tem 77 páginas pequenas, composição de coluna de jornal, e foi publicado no nesta cidade do Rio de Janeiro, na Tipografia Aldina, Rua da Assembléia, n 96, em 1900.

Coelho Neto, ao falar das Canções sem metro cita o crítico anterior, Transcrevendo o seguinte: a propósito das Canções sem metro de Raul Pompéia narra Rodrigo Otávio: “Esses pequenos quadros foram escritos em S. Paulo, em 1884, estando Pompéia no quarto ano da Faculdade de Direito; morava ele, então, em uma casa da Rua do Chá (hoje Barão de Itapetininga), onde também, por esse tempo, vivia Coelho Neto”. 
Efetivamente, diz ter residido com Pompéia, à casa da Rua do Chá, pensão de um senhor chamado Rafael, de Piracicaba, homem quase cego, mas de olho vivo e nervos enfezados. Argos mais vigilante que o da fábula, levantava-se às cinco da manhã, e de cigarro à boca, caminhava pela casa, aos resmungos, fiscalizando o que se passava, desde o procedimento dos inquilinos, pautado pela mais rigorosa disciplina moral, até o cheiro dos refogados que vinha cozinha.

Nessa casa, onde também morava Figueiredo Coimbra, que escrevia n’O Diário Popular e fazia versos cândidos a uma moçoila da vizinhança, compôs Pompéia algumas das suas “canções”. Foi, porém, em um chalet da Rua Vitória, a dois passos de S. João, que o autor da Tragédia no Amazonas deu largas à imaginação na obra que tanto pregava. Foi isso em fins de 1884, quando se libertaram do cego e das suas manias.

Eram todos companheiros no tal chalet, cujos lambrequins tanto os orgulhavam, Carlos de Magalhães, um mineiro escanifrado, com mais espinhas do que um bagre, que, por economia de roupa, andava em casa de guarda-pó sobre a pele. Pompéia, com o seu melindroso pudor, se tinha necessidade de passar por ele, tirava o pince-nez e gritava-lhe de longe:

- Componha-se, senhor!

E Carlos, só para o pirraçar, “abria o chambre”, como chamava ao guarda-pó. O escândalo estourava em bate-boca. Outro: Artur Itabirano e, finalmente eu, com dois negros que me acompanhavam, um que era cozinheiro, outro que passava os dias assobiando, à espera da ordem de embarque para o Rio, consignado à Confederação Abolicionista.

O quarto de Pompéia, fronteiro à escada, como guarita de portageiro, era um caos. Mobiliário de aluguel: cama, mesa, uma cadeira com assento de esparto, duas pequenas estantes de ferro atochadas de livros e uma canastra embaixo da cama. E livros, pelos cantos, às pilhas; rimas de livros em cima da mesa, livros espalhados pelo chão, e jornais e revistas. No cabide a andaina e o chapéu.

Pompéia não tinha vícios: detestava o fumo e o álcool, permitindo-se, uma vez por outra, um copo de cerveja no Corvo, para molhar a palavra na palestra. De saias, fugia como o diabo da cruz. Lia na cama até tantas da noite, e se algum trecho o entusiasmava declamava-o com ênfase trágica, provocando protestos do Carlos, que preferia o sono a todas as literaturas do mundo. Escrevia em pedaços de papel e só ele, ele só, decifrava as garabulhas traçadas em várias direções, formando intricadíssimo aranhol. 
Muitas vezes o encontrei nervoso, procurando interpretar aranzéis da própria pena e eu, francamente, não sei como conseguiram os tipógrafos tirar daquele arro, o ouro que hoje refulge e enriquece a nossa literatura.

De uma honestidade “mórbida”, certa vez, só pelo fato de o colega haver observado vaga semelhança entre uma das suas canções e um fragmento de Schopenhauer, franziu o sobrolho e, encarando-me ferrenho, rosnou em voz surda:

— Pensa, você, talvez, que plagiei, não é?

E, rápido, fremente, rasgou o papel, fê-lo em migas, atirando-as, com desprezo, à rua.

O seu ideal era dar às “Canções” em edição de luxo, ilustrada por ele próprio. Dias antes da sua morte, visitando-me na Rua Silveira Martins, ainda comentou esse sonho.

Ele foi-se quando os anjos saíam do céu em coro e espalhavam-se no espaço para anunciar o natal. Matou-o a ânsia de perfeição. Convencido de que não a encontraria na vida, foi-se a buscá-la... onde? Quem sabe lá!

17 dezembro 1925. In revista da Academia Brasileira de Letras. Rio de Janeiro, n. 49. jan, 1926, p. 62-64 (POMPÉIA, Raul. Canções sem metro, org. Afrânio Coutinho,v. IV, 1982, p.15-28).

Logo depois de sua chegada ao Rio, Pompéia enceta a publicação de muitos de seus textos do Recife, nas páginas da Gazeta da Tarde. Juntamente com Alma morta, vem à luz a segunda série de suas Canções sem metro, que davam seguimento ao trabalho iniciado em São Paulo. As Canções sem metro foram publicadas nos periódicos entre 17 de dezembro de 1885 e 29 de janeiro de 1886. Elas sofreriam, até 1889, sensíveis modificações de forma, além da inclusão de uma ou duas canções e da exclusão de outras tantas. Em linhas gerais, entretanto, pode-se dizer que o trabalho então publicado estava bastante próximo do que se pode chamar de forma definitiva, se o autor não se mantém vivo, no sentido físico, uma vez que textos de gênios, como os de Pompéia estarão sempre contextualizados e sendo modificados na recepção diacrônica com a qual sempre estarão em dialogismo intertextual.

A prosa poética, na linha anteriormente praticada por José de Alencar, já era utilizada com freqüência em seus contos e crônicas, do mesmo modo que o seria mais tarde em O Ateneu. Capaz (2001), acrescenta que em razão da dificuldade do autor com a métrica e com a rima, numa época 
em que o verso livre era apenas objeto de experimentação de alguns poucos inovadores, não achou assim melhor maneira de expressar-se poeticamente que através do poema em prosa - que nada mais é que a prosa poética acondicionada numa forma bastante complacente.

Segundo Capaz (2001, p. 89), em seu livro Raul Pompéia Biografia, Pompéia submete o seu texto a um intenso trabalho de cinzelamento e alguns poemas, nessa busca da expressão ideal, chegam a ter duas ou três versões antes da forma definitiva. Há neles o mesmo pessimismo irremissível e a mesma visão desencantada do mundo, concentrados numa prosa que vai pouco a pouco ganhando densidade do mundo, na medida em que se descarnava e ganhava delineamentos conjeturais.

Qual o motivo de as Canções sem metro, que tomou tanto tempo de Raul Pompéia não ter tido sucesso, ao contrário de O Ateneu? Por que foi recebida tão friamente pela crítica e pelos leitores, a ponto de nunca ter sido reeditada em quase 60 anos, e estar hoje em terceira edição? A resposta certamente está em que o leitor comum não se sensibiliza com a literatura pessimista, que não fala de alegria e do amor, das belezas do mundo e da vida. E a nota amorosa é a grande ausente nas Canções. Ali a visão do mundo é a mesma de Alma morta, desencantada e triste, sem concessão ao humor, que mascara a miséria e sorri as tristezas, e que muitas vezes pode atrair o leitor para obras desse gênero.

Pompéia pretendeu fazer uma obra orgânica, que fosse uma visão totalizante do universo, lírica e filosófica ao mesmo tempo, do ponto de vista do homem pessimista do final do século XIX, descrente das conquistas da ciência e confuso diante do imenso abismo de interrogações que o desafiavam. É o canto tristemente belo de Alma Morta que lastreia os seus poemas, onde não cabe nenhuma ode a alegria. Quando muito, nas páginas finais, faísca um canto em louvor às revoluções sociais, numa espécie de convocação á luta contra as injustiças prenúncio das idéias, que o empolgariam nas futuras campanhas pela consolidação da república, época em que passou a pregar um ideário nacionalista, de forma ainda meio vaga.

Na primeira parte do livro, à qual deu o título de Vibrações, estão os poemas publicados em São Paulo, entre 1883 e 1884, no Jornal do Comércio e no Diário Mercantil, que na edição definitiva viriam precedidos por uma quadra do poema Correspondances, de Baudelaire. 
Para um sensorial como ele, a vibração era a própria vida, que lhe chegava através dos sentidos, principalmente da visão: "Vibra o abismo etéreo à música das esferas; vibra a convulsão do verme, no segredo subterrâneo dos túmulos. Vive a luz, vive o perfume, vive o som, vive a putrefação. Vivem à semelhança os ânimos”.

Nas vibrações estão as cores da natureza identificadas com os sentimentos que lhes correspondem. O verde se identifica com a esperança, o amarelo é o desespero da mulher abandonada em seu leito de morte, depois de uma vida de devassidão e de fausto, ao tempo em que se cobria com jóias de ouro. O autor visualiza o azul no ciúme da mulher abandonada a olhar tristemente o infinito do céu. Já o roxo é a tristeza, "tinta tomada à palheta do ocaso e às flores da morte” - as violetas. E a pobre mãe que olha o potente afogueado em sangue, só se vê nele o vermelho da guerra, para onde seguiu o filho na viagem sem volta ao contrário do branco, que á a paz que se segue ao conflito, o branco das neblinas que cobrem os campos, o branco da "estrela plácida das tardes” e também da lua que vai “pelos caminhos, semeando a difusão suavíssima da paz”. A morte é a cor negra que nos envolve mesmo nos mais claros dos dias: “as escuras noites do espírito”. Bem diversa do rosa, a cor do amor, que se desenha no “sorrir das virgens”, no “adorável pudor” e na “primeira luz da manhã”.

Além das cores da natureza, Pompéia encontra espaço em sua paleta para as cores que moram nas almas torturadas pela brutalidade, nos seres vencidos pelo cansaço, mutilados pela escravidão, que votam um ódio mortal ao escravizador. Neles sobrevive a coloração indistinta dos sentimentos, cor que não se define. Um exemplo é “a cor sem cor do tédio, que habita as criaturas cansadas de viver”. “Há também nas almas o incolor diáfano do vidro (...) E os dias passam, que vou contando lento, lento, torturado pela implacável cor de vidro que me persegue”.

Raul Pompéia, que em $O$ Ateneu se revelaria um curioso miniaturista, nas Canções sem metro amplia o espectro de suas preocupações, numa busca incessante de infinito.

A partir das historietas que formam o capítulo das Vibrações as motivações metafísicas se aprofundam. É o que dizem os títulos dos últimos capítulos: Vaidades e Infinito. O irmão intelectual de Schopenhauer e de Leopardi, percebe o universo à sua volta e reconhece-se esmagado por sua grandeza. 
Nesse universo de uma grandeza estonteadora, onde só há interrogações e dúvidas, nada explica o absurdo da existência, nem mesmo as exaustivas pesquisas das ciências em sua ânsia de devassar o mistério. No mundo cercado de interrogações, só o trabalho artístico e as lutas em favor da liberdade podem servir de refúgio ao ser humano, trazendo-lhe satisfação e consolo. A revolução sempre se apresenta a Pompéia como um sol afugentando as trevas da opressão, ambiciosas e sanguinárias, à semelhança de Macbeth. A não ser por essas duas válvulas de escape, não há vislumbre de saída ante o enigma do infinito.

Infinitos são os astros, que no rumor do espaço zombam das agitações humanas. Infinitas são as lembranças e as cinzas dos antepassados, legado de que nos servimos como um repasto em honra dos vindouros. Infinito é o vulcão extinto que se abre para as profundezas da terra, mostrando-nos sua “imensa boca torcida na expressão de feroz agonia”. Infinita é Atlântida, continente perdido sob uma campa amplíssima, cujo mistério só os monstros marinhos podem desvendar.

Frente a tantas interrogações, Pompéia não procura consolo nas religiões ou nas crenças. Como um deus pagão, contenta-se com o sol, o adorado sol criador das cores e dos dias. E pergunta: "Por que buscar mais alto a divindade?!”

No orgulhoso século que imaginou achar o segredo de todas as coisas, o poeta chega ao fim do seu poema cansado e de mãos vazias. E o fecha com um canto desesperançado, de desoladora beleza.

Apesar de haver optado pelo levantamento mais completo da recepção crítica de Pompéia, não me limitando apenas à crítica referente a Canções sem metro, mas tendo em vista o objeto da pesquisa, quero chamar a atenção para os pontos consensuais em relação à prosa poética de Pompéia.

Os críticos concordam que ele teve influência de Baudelaire, assim como indiretamente de Bertrand e Victor Hugo. Pompéia foi o introdutor daquele gênero inovador no Brasil. Apresenta uma escritura artística de caráter impressionista. Por compor o miniaturismo, percebe-se também a influência dos irmãos Goncourt. Sua prosa poética é marcada pela eloqüência e pela retórica. Há, ainda, proximidade estilística entre as pequenas narrativas da série microscópicas e sua prosa poética ou poemas em prosa. Seu questionar metafísico busca 
uma cosmogonia. Percebem-se as correspondências universais de Swedenborg, junto a uma espécie de pessimismo e nirvanismo.

Refletindo sobre o pequeno poema em prosa, segundo Morier (1981), em torno de 1840, a idéia do poema em prosa estava no ar, ou melhor, ela se desenvolvia como um novo estilo na literatura e em movimento contínuo. O romantismo encontrou esse gênero misto um meio de expressão de acordo com suas tendências, porque o romantismo e o poema em prosa têm em comum: o gosto pela harmonia, pela mistura de gêneros, pela variedade, pelo movimento e o gosto pela liberdade e pelo idealismo. Charles Bruneau reconhece que Aloysius Bertrand inspirou Baudelaire. Então, as dimensões anteriores do poema em prosa diminuem, ou seja, o texto é dividido em seções e cada uma delas se apresenta como uma pequena pintura, tendo sua própria unidade. Com Bertrand, o pequeno poema em prosa atinge a forma mais bem definida, ocupando o tamanho de uma página de texto compacto, mas repartido em unidades, ele se estende a cerca de duas páginas impressas. Bertrand é o criador de uma forma delicadamente nuanceé, em que as palavras apresentam uma língua harmoniosa e um sentido poético real e acoplam no interior de páginas vivas e preciosas como as iluminuras. Percebe-se a essência poética em suas composições. Guérin faz uso de uma fórmula menos rigorosa, mas acrescenta ao poema em prosa determinados fechamentos periódicos com refrão. Desde então cultivaram duas formas, a prova cadenciada o poética e o poema em prosa que se desenvolveram paralelamente. O poema em prosa torna-se mais musical e organizado. Em alguns casos, a combinação de semelhança fonética parcial e a disparidade sêmica provocam um efeito inusitado, a surpresa ou estranhamento, frases curtas que provocam movimento em contraposição às orações nominais que predominam na descrição da paisagem passiva que assiste às ações do tempo implacável (MORIER, 1981, trad. nossa).

A concepção de História na obra de Raul Pompéia e o papel atribuído à memória que ela resgata e preserva foi objeto de estudo de Lopes e Silva (2004). E em seu ensaio sobre a Filosofia e a História em Pompéia afirma que a obra, Canções sem metro, apresenta, uma grande narrativa da humanidade que possibilita o reconhecimento de uma Filosofia da História. Contrariando as ideologias dominantes no final do século XIX, constatamos uma reação à idéia positiva de progresso, que se expressa numa visão decadentista e cíclica do tempo histórico, cuja escatologia sem deuses nos remete, após o cataclismo final, ao tempo 
sem máculas da origem. Entretanto, apesar do pessimismo do sistema, observa-se o desejo revolucionário de romper o ciclo infernal. E ao artista cabe a tarefa, assim como ao escritor, de registrar a tragédia dos ideais com o provável objetivo de manter viva esta chama.

Quanto à cosmovisão de Pompéia, há mais divergências do que em relação a seu estilo. Por isso, o referido pesquisador chama a atenção para a necessidade de uma análise mais holística que busque compreender as contradições, tendo em vista a riqueza e a organicidade dos textos de caráter cosmogônico. Acreditamos que seu estilo demonstra a sua cosmovisão, conforme podemos observar pela análise de sua prosa poética, pelo cuidado tão bem sucedido com que a construiu. E, lembrando Da Cal (1981), o escritor só pode desenvolver ou criar um estilo se ele tiver uma visão de mundo própria e for capaz de expressá-la. A análise das Canções sem metro, de Pompéia comprovam que ele o conseguiu. 


\section{JORNALISMO E LITERATURA / TEXTO-IMAGEM}

No final do século XIX, o que mais se fazia era discutir, pôr em dúvida, analisar, combater, questionar a pretensa sacralidade de instituições como: a escravidão, a monarquia, o latifúndio. E a imprensa tinha em suas fileiras grandes combatentes, figuras exemplares, como os homens de jornal e como os homens de inteligência ou de cultura. É importante ressaltar que os fenômenos de construção textual, percebidos em A Gazeta da Tarde e na revista A Galeria Ilustrada demonstram muita riqueza na imaginação literária e jornalística do final do século XIX, ainda merecedora de mais estudos pela historiografia literária e jornalística de nosso país.

Em seu trabalho intitulado: Literatura e identidade nacional: Raul Pompéia e os percalços do nacionalismo brasileiro, Roberto Ventura afirma que "a transição da monarquia para a república é marcada, entre outros aspectos, por acirradas polêmicas intelectuais”. O pesquisador, analisando a história cultural do período, lembra o empenho da inteligência nacional da época em debater questões, até hoje não resolvidas, tais como nação, nacionalidade, raças, regiões, natureza x homem, influências estrangeiras, cultura e literatura brasileira, história política (1991). As transformações que vinham transcorrendo desde a década de 70, com o fim da Guerra do Paraguai, a intensificação da campanha abolicionista e do movimento republicano, as influências das idéias cosmopolitas oriundas da Europa darwinismo, cientificismo, evolucionismo, positivismo - exigem da elite intelectual brasileira uma atitude de ação e não mais de observação passiva da vida cotidiana, ou seja, o exercício intelectual somente teria significado se manifestado como atitude política. A esse ímpeto de participação política dos intelectuais brasileiros do final do século XIX e início do século XX, Nicolau Sevcenko chamará de "escritores-cidadãos" (SP, 1983). Para os intelectuais, os grandes temas estavam colocados: como elevar o conceito de nação se essa se encontra alicerçada sobre a escravidão? Por que o estágio de desenvolvimento e civilização do Brasil não se encontra no mesmo nível da Europa? O regime monárquico constitui um entrave para o país alcançar o "progresso"? É exatamente nesse contexto que se encontram inseridas as idéias e a militância política de Raul Pompéia (1863-1895), objeto de investigação dessa pesquisa. Muito embora tenha muitas semelhanças com o perfil de outros intelectuais do tempo, Raul Pompéia vai se diferenciar por desenvolver convicções políticas vinculadas ao movimento 
conhecido como jacobinismo. A defesa intransigente do ideal republicano, o nacionalismo exacerbado e o radicalismo são as marcas dominantes de seu pensamento que contribuíram para que pusesse fim à sua vida aos 32 anos. O autor mantinha uma idéia obsessiva, ou seja, a sua indignação com a realidade social, econômica e política do Brasil de seu tempo.

De acordo com Ribeiro (2003), pode ser observada, no Brasil, a presença de um campo resultante da intersecção entre ficção e imprensa periódica no século XIX, em que um grande contingente de escritores atuava nos jornais e nas revistas brasileiras. Eles faziam uso desses veículos para a publicação de sua produção ficcional, em forma de romances e de narrativas curtas, assim como crônicas, críticas artísticas, generalidades, comentários e outros textos jornalísticos. Em seu texto Texto verbal e imagem visual em O Ateneu (2003), o mesmo pesquisador diz que uma estratégia se evidencia na utilização de traços de representação artística, próprios da teoria visual do estilo impressionista. Em estudo mais aprofundado sobre o impressionismo na pintura, Francastel (1974, p.62-4, 87, 160-5), estudado por Ribeiro (2001), que reconheceu e aplicou as suas categorias em análise sobre $O$ ateneu, define os seguintes traços gerais da teoria visual dos impressionistas: registro visual de fenômenos de consciência e substituição das leis da experiência objetiva pelas da experiência subjetiva, interesse de criação ligado à inovação no terreno da realidade psicológica na sua união com o realismo formal, elaboração das sensações dadas pelos cinco sentidos, pintura fundada no registro das sensações com a substituição da perspectiva do espaço pela simples profundidade, visão de equivalências no processo de criação, ou seja, a busca de um equivalente plástico para cada sensação e emoção, necessidade de analisar as sensações, gosto pela fixação do efêmero e do fugidio: o instante ou o gesto que passam, papel fundamental da luminosidade, fixação dos aspectos fugitivos da vida, recorrência ao jogo caprichoso das sombras, jogos de luz, atração pela animação, seres em movimento e mecanismo dos gestos, distanciamento da escola naturalista em virtude da apresentação de um realismo de ordem espiritual.

Os primeiros veículos de informação periódica produzidos no Brasil antecedem de pouco a Independência. No primeiro império e no período das regências, o jornalismo era uma atividade publicista de alto risco, exercida em veículos geralmente de vida efêmera. Só no Segundo Império, em ambiente de mecenato, surgem algumas características peculiares de estilo. Jornalistas, na época, eram escritores, alguns notáveis, como Machado de Assis ou Raul 
Pompéia; adotavam, em geral, um texto literário simplificado, que se manifesta, por exemplo, nas Crônicas do Senado, de Machado.

A Gazeta da Tarde, que publicou, em 1886, as canções selecionadas como as mais representativas, no presente estudo, também trabalhava em denegrir a tudo e a todos, tendo conquistado uma situação de incrível renome, segundo Sodré (1999). O proprietário do jornal à época, José do Patrocínio atacava pessoalmente o imperador e da mais insolente maneira que se possa imaginar. Fizesse ele o mesmo em qualquer outra república, e não estaria assentado ali, atrás das grades de madeira da bancada da imprensa, mas atrás das grades de ferro de uma cadeia. Alguns até defendiam a prisão dos jornalistas brasileiros.

Na Gazeta da Tarde, Patrocínio apoiava Deodoro. A causa da Abolição destacara, em São Paulo, um grande jornalista negro, Luís Gama, amigo pessoal de Pompéia. Destacaria esse outro, no Rio, José do Patrocínio, que começara, em 1877, colaborando na Gazeta de Notícias, de Ferreira de Araújo, até 1881, e comprara logo depois a Gazeta da Tarde e, mais adiante, a Cidade do Rio, tornando-se um dos mais apaixonados lutadores pela causa dos escravos.

É preciso lembrar que naquela época os homens de letras viviam praticamente da imprensa: ela é que lhes permitia a divulgação de seus trabalhos e o contato com o público. $\mathrm{O}$ próprio escritor Raul Pompéia deixou contos e as meditações de Alma morta, na Gazeta da Tarde, em 1888. Além disso, os textos do corpus desta pesquisa foram todos publicados naquele jornal em janeiro de 1886.

Algumas figuras dessa geração curiosa, de uma fase em que a imprensa e a literatura se confundiam tanto, ainda estão no anonimato. Isso, por si, mostra como a imprensa engatinhava, não tendo criado ainda, a sua própria linguagem e definido o seu papel específico. Esse fato contribuiu para que algumas das figuras destacadas daquele tempo desaparecessem e permanecessem no esquecimento até os dias de hoje.

Nas crônicas, à época de Pompéia, seguem as críticas aos escravocratas, à época liderados no Rio de Janeiro pelo chefe de polícia Coelho Bastos, personagem de humor azedo a quem aprazia exibir autoridade de maneira arrogante, quer raspando a cabeça de negros suspeitos de terem fugido ao cativeiro, quer combatendo o popular costume do entrudo, 
tradicional no Rio de Janeiro, em que os foliões se divertiam com seus limões de cheiro e esguichos d’água.

Nesse tempo, entretanto, Pompéia vivia uma fase de pouco entusiasmo, em relação à causa abolicionista, ou porque achasse que aos poucos o problema se encaminharia para uma solução política, ou porque imaginasse, com certa razão, que a guerrilha miúda contra os negreiros não era o método mais adequado para se alcançar um remate definitivo e completo, que alcançasse a nação por inteiro. Em razão disso, vez por outra descambava para a ironia, como ocorreu em relação a candidatura de Quintino Bocaiúva para a Câmara dos Deputados, vaticinando o seu fracasso se insistisse em seu programa de luta contra a escravidão no Brasil, que afugentaria possíveis eleitores, pois as classes votantes, afirmava, não estavam interessadas na abolição:

\footnotetext{
"A multidão gosta de esquecer os seus pecados. Por isso há os bailes: circenses. Se um candidato vem assombrá-la com perspectivas medonhas, embora reais, a multidão volta-lhe as costas.

Fica entendido que quando falo de multidão, refiro-me à multidão que vota; perante a lei, não há outra. O representante da nação não representa o povinho sem renda. Isto não é nação; embora possa vir a ser exército, se as fronteiras quiserem.

A minha multidão tem o que perder.

É a esta multidão que se dirigiu o benemérito jornalista d”O País; é esta multidão que vai abanar com a cabeça ao honrado candidato do $1^{\circ}$ distrito, ao pé de urna. Quem mandou Quintino Bocaiúva ser Quintino Bocaiúva?” (GAZETA DA TARDE, 24.12.1885).
}

Foi neste estado de espírito que ele aceitou o convite para ingressar no corpo de redatores do Jornal do Comércio, em meados de 1886. Ali ele viveu uma estranha fase em sua vida de combatente da liberdade, comentando o dia-a-dia da política do ponto de vista governamental, defendendo o ministério conservador do barão de Cotegipe, tecendo elogios ao imperador e ao "seu elevado grau de saber e entranhado amor pelas letras e pelas as ciências". Ou mesmo tecendo críticas a políticos do Partido Liberal, como Joaquim Nabuco ou ainda 
combatendo o açodamento dos abolicionistas, a pretexto de que a libertação já estava próxima, inclusive por contar com o apoio do próprio governo.

Tais deslizes só se podem justificar por se tratarem de artigos de natureza redatorial, vinculados à linha conservadora do jornal e elaborados ao tempo em que o cronista cobria as atividades da Câmara dos Deputados. Só assim podemos entender que ele denomine Cotegipe como um “estadista ilustre, cujo nome é um patrimônio nacional”, o que sem dúvida era verdadeiro, embora soasse estranho, vindo de Pompéia. Só por obediência a um dever profissional, poderemos aceitá-lo, quebrando uma linha de estrita coerência, a qualificar o estadista baiano como "um brasileiro ilustre, que deve ter glória em oferecer aos seus concidadãos a história de uma existência, já longa, consagrada toda inteira à felicidade de sua pátria, história em cujas páginas fulguram traços relevantes do mais alevantado civismo” (JORNAL DO COMÉRCIO, 12.06.1886).

Surpreende, do mesmo modo, vê-lo atacar os movimentos de rebeldia republicana de alguns membros do Congresso. Se é certo que a mudança de regime nunca lhe mereceu a importância do abolicionismo, são no mínimo contraditórias suas opiniões a respeito do deputado mineiro Afonso Celso Júnior, que à época pregava a mudança do regime: “O brasileiro, o mineiro, é eminentemente monarquista; a idéia de república passa-lhe com disfarces pelo espírito sem impressioná-lo. Ele sabe de própria experiência que os pregadores da república não são sérios. A idéia de monarquia é co-natural à índole nacional (JORNAL DO COMÉRCIO, 7.07.1886 apud CAPAZ, 2001, p. 89-98).

Segundo Capaz (2001), o talento de Raul Pompéia, que oscilava entre a literatura e as artes plásticas, passou a dedicar-se por inteiro ao jornalismo, à época um dos poucos tetos que podiam abrigar artistas com talento para as letras ou para o desenho, além da função pública, que no Brasil sempre foi o porto seguro dos escritores que comungavam com as diretrizes do governo ou pelo menos não lhe fossem francamente contrários, o que não era exatamente o seu caso, que depois de poucos meses de atividade já tinha abandonado o Jornal do Comércio e só esporadicamente publicava contos ou crônicas na imprensa.

Há de se considerar que o reconhecimento interno do escritor não parece mais fácil que o externo e essa aspiração pode manifestar-se de várias maneiras. Muitas vezes alguns 
escolhem o caminho da profissionalização por vias paralelas, como a imprensa, alternativa discutida desde a época de Raul Pompéia, Lima Barreto, Coelho Neto e Olavo Bilac, ou a política, que conferem personalidade pública ao artista; ou quando prefere uma institucionalização não de sua arte, mas de sua pessoa, promessa contida nos regimentos de todas as Academias, as brasileiras e nacionais, bem como as estaduais e as municipais.

No Brasil, o estudo dos jornais e revistas dessa época oferece particular interesse ao curioso traço psicológico na História, ao interessante traço íntimo do passado. A análise de determinados anúncios de jornais e revistas pode oferecer uma nova forma de investigação sociológica na história do desenvolvimento sócio-cultural do povo brasileiro.

Observando o perfil de periódicos, percebe-se que floresce no país, nas seções meio ineditoriais das gazetas, toda uma deliciosa documentação da vida, da moral, do gosto, da indumentária do homo brasiliensis, que vem desde os remotos registros da imprensa brasileira, Freyre (1987). Há anúncios de escravos fugidos, entre tantos outros, em linguagem satírica, que provoca a imaginação do leitor, em relação à biometria, à antropologia, à patologia tropical, à etnologia médica, mesmo à indumentária, expressões valiosas, em termos antropológicos.

E é preciso não nos esquecermos da instituição, tão brasileira, das secções - Solicitadas e Apelidos - superfície em que lemos, em arrepios ou fervuras de escândalo, conforme descrição de Sodré (1999), tanta intimidade social, assim como questões pessoais, segredos de família e mesmo incidentes patológicos que em outros países estariam guardados dentro das casas e das alcovas.

Também as Seções Sociais nas folhas brasileiras, principalmente nas páginas da província, constituem uma espécie de paraliteratura de particular interesse para o psicólogo social. É aí que os aniversários, os falecimentos, os batizados, os casamentos, os desembarques são registrados ou anunciados com muito florido de frase. É aí que as mães deixam de ser mães para aparecerem amantíssimas genitoras. E os pais se apresentam como venerandos ou acatados progenitores. É o local em que os funcionários públicos passam a zelosos funcionários de categoria da repartição “tal” (FREYRE, 1987). E os comerciantes abastados ou acreditados comerciantes. Os dias de anos não passam simplesmente, como os outros dias, mas transfluem. Tudo se transformava sob um especialíssimo vocabulário em que os odjetivos são os senhores, os reis, os caudilhos; e os substantivos, seus simples acaudilhados. 
Certamente os estrangeiros achavam graça nas velhas e pitorescas expressões de regozijo, que constituíam algumas das solicitadas de jornais, hoje, em declínio. Nessas, parentes ou amigos de um aniversariante se regozijavam efusivamente por esse poder colher mais uma flor no jardim de sua preciosa existência, ou ainda, uma expressão mais caracteristicamente brasileira, - colher mais um caju. Esses fatos são realmente pitorescos, saborosamente provincianos. Eles são, sobretudo, originalmente brasileiros, como o código lingüístico, utilizado nas matérias relativas às secções: solicitadas ou apelidos.

Todos esses processos e todas essas técnicas jornalísticas, as expressões de persuasão são preciosas para, por meio do cuidadoso exame do que nelas é forma, a serviço de conteúdos que vêm variando com o tempo, empreender-se um estudo sistemático da história social brasileira tal como se tem refletido na imprensa mais caracteristicamente nacional, cujas secções, solicitadas, avisos e anúncios, se tornaram uma espécie de sucessora das denunciações e confissões dos tempos coloniais da inquisição.

E essa é uma literatura, solicitada, disputada. Os rapazes da imprensa encarregados dela a 150\$000 por mês, eram pessoas aduladas, às vezes, pela burguesia de toda a espécie. Agradada a café e bolinho, a profusos copos de cerveja e finos doces; a champagne, a vinho do porto, a sanduíche de peru, a pastel de nata.

Em A vida literária no Brasil lê-se que a industrialização da imprensa não se vinha fazendo com prejuízo sensível da literatura. A maioria dos jornais do Rio continuava a acolher e a pagar colaboração literária. O Jornal do Comércio pagava a trinta, cinqüenta e até sessenta mil réis a colaboração; o Correio da Manhã pagava cinqüenta.

Mas não se pode negar que os jornais, proporcionando trabalho aos intelectuais, mesmo quando se tratava de simples rotina de redação, sem nenhum cunho literário, facilitava a vida de muitos deles, dando-lhes uma segunda ocupação condigna, na qual podiam, certamente, criar ambiente para as atividades do escritor. Lembremo-nos de que a imprensa propiciara, como continua a propiciar, a mudança para a metrópole de grande número de intelectuais, que não conseguiriam realizar-se literariamente, se permanecessem no recanto nativo da província.

Bilac dizia que sua geração, que não teve outro mérito, senão o de desbravar o caminho, também fez da imprensa literária uma profissão remunerada, impôs o trabalho. Antes dessa 
geração, Alencar, Macedo e todos os que traziam a literatura para o jornalismo eram apenas tolerados: só o comércio e a política tinham consideração e virtude. Mas é preciso concordar que se pôde ver no jornalismo pelo menos uma face favorável à arte literária.

Por volta de 1888, A Gazeta de Notícias era a folha que mais abria espaço à colaboração literária no Brasil, e que melhor pagava os escritores, só encontrando um concorrente nesse terreno - O Diário Mercantil -, de Gaspar da Silva, em São Paulo. E tudo isso em um país como o Brasil, em que quase ninguém na época e até hoje encontrava meio para viver da própria produção literária.

Infelizmente com o processo da industrialização da imprensa, ao final do século, os jornais foram gradativamente sacrificando os artigos em favor do noticiário e da reportagem. As notícias de polícia, particularmente, tornaram-se as prioritárias o que depois, no século XX, dará origem ao romance reportagem. Os escritores irão fazer da reportagem um gênero literário, vindo assim a servir simultaneamente ao jornalismo e à literatura.

Ferreira de Araújo era alguém que tornava possível a arte literária no jornal, porque o jornal deixava de ser uma indústria, ou seja, para ele, uma atividade, como o jornalismo, não prejudicava a literatura. Pode ser que, se Ferreira da Araújo vivesse mais tempo, tivesse cedido também aos imperativos da industrialização dos jornais.

A publicação dos textos ilustrados: Canções sem metro, em A Galeria Ilustrada, contribui, sem dúvida alguma, para ampliar as discussões sobre a obra. Esta pesquisa faz questão de ressaltar sua importância, trazendo nossa contribuição para a completude de sua prosa poética, expressa ao mesmo tempo em duas linguagens artísticas: texto e imagem. Por isso, incluí no anexo, os textos de: A Galeria Ilustrada, como modelo do perfil da imprensa ficcional de uma revista da época, com o objetivo ainda de completar a nossa percepção, relativa à presença do visual na linguagem verbal do autor em estudo e, aqui, no final deste capítulo comento um dos textos, observando a sua forma semelhante aos pequenos poemas em prosa de Baudelaire.

É importante ressaltar a riqueza criativa do texto imagético e aprender a trabalhar uma obra híbrida, unindo texto e imagem, sem diminuir a importância de um em detrimento do outro. Pouca gente sabe que as primeiras edições d’O ateneu, de Raul Pompéia, traziam várias 
ilustrações do próprio autor e que Canções sem metro foi publicado sem suas ilustrações cinco anos após a morte do autor. Quando o livro foi editado sem essas gravuras, muitos críticos viram nisso mais um ato arbitrário do mercado editorial da época e há de se concordar com eles. Não é só nos bons livros juvenis que texto e imagem se fundem para formar uma obra única e indivisível. A alta literatura está cheia de casos assim e podemos citar os poetas do concretismo, como exemplo.

È importante o estudo do texto ligado à imagem na obra de Pompéia. Esse tema pode ser objeto de nova pesquisa, porque foge ao nosso objetivo aqui. Devido ao ineditismo das Canções sem metro ilustradas, da Revista A Galeria Ilustrada, os textos foram anexados ao trabalho, conforme o dissemos na introdução e um deles será comentado e um outro usado como exemplo nesta pesquisa. Todavia, há inúmeras ilustrações de Pompéia ainda perdidas e esse fato pode constituir trabalho de pesquisa posterior. Muitas de suas composições mesclam imagem e texto e acreditamos que possam ser encontradas ilustrações ainda desconhecidas, capas de livros que ele ilustrou para amigos, caricaturas e outros.

Arbex (1998), em seu texto mencionado nas referências, diz das relações entre a pintura e a literatura vistas a partir do Surrealismo, enfocando o poeta Max Ernst, e tomando como elementos para a comparação os conceitos de intertextualidade e de intericonicidade. Uma analogia pode ser feita, uma vez que Raul Pompéia destacou-se como caricaturista e as Canções sem metro, em suas primeiras versões, apresentava ilustrações feitas pelo próprio autor.

Partindo do princípio que o que caracteriza ambas as linguagens é a utilização da colagem/ílustração, como recurso poético e como técnica de produção de imagens, a autora procura delimitar o campo conceitual da ilustração, mas propondo, por um lado, uma análise do corpus literário, a partir do conceito de intertextualidade e, por outro lado, em nível pictural, uma leitura das imagens, através do conceito de intericonicidade.

Como a autora se ateve ao surrealismo, as correspondências entre as artes não se limitavam a uma questão de colaboração entre artistas e poetas ou de afinidades temáticas. Na verdade, os artistas buscavam procedimentos análogos aos utilizados pelos poetas para atingir a centelha poética, para desvelar imagens interiores ou imagens até então inconscientes. Ela 
afirma que um desses procedimentos é a colagem, pois como técnica, a colagem foi utilizada pelos cubistas desde o início do século passado e também pelo dadaísmo.

Os surrealistas fizeram da colagem, inicialmente, uma simples técnica de produção de imagens, um recurso poético e, mais precisamente, um procedimento capaz de produzir imagens equivalentes às imagens poéticas elaboradas a partir da escrita automática.

Em se tratando de texto imagem, observa-se que ela constitui a reunião de duas realidades de comunicação estética e que as canções ilustradas por Pompéia apresentam duas linguagens: a icônica e a verbal, sob a forma de um gênero inovador.

Ao examinarmos o corpus literário, verificamos que ele é composto de poemas, romances, narrativas poéticas que, em grande parte, vêm acompanhados de imagens, cuja função vai além da simples ilustração, formando uma unidade híbrida.

No nível frasal, o autor emprega o procedimento da colagem verbal, ao inserir textos provenientes de diversas fontes, modificando-os, na maioria das vezes, com fins paródicos. No nível de gênero, Pompéia inova trabalhando a prosa aliada à poesia. No nível da palavra, a colagem é caracterizada na criação de neologismos e jogos de palavras. Na verdade, os procedimentos literários utilizados correspondem, de maneira geral, ao projeto inovador de Pompéia. Assim o escritor utilizou a escrita, as associações verbais, os temas oníricos, as metáforas e os jogos de palavras, como meios de captar e dar forma às imagens poéticas interiores, criando um novo gênero.

Em resumo, podemos dizer que o que caracteriza a linguagem de Pompéia é a utilização da ilustração tanto como recurso poético e como técnica de produção de imagens. Seus textos apresentam a colagem visual, isto é, imagem + texto, resultante da justaposição de um texto e de uma imagem no mesmo espaço de representação, o periódico ou o livro. Tais observações apontam para a proximidade entre a colagem e as formas de intertextualidade, fazendo com que a colagem torne-se sinônimo de intertexto também na obra de Raul Pompéia.

O termo colagem é um signo emprestado da pintura e designa os procedimentos que consistem em colar materiais heterogêneos, aqui, duas linguagens; por extensão, torna-se 
sinônimo de citação, intertexto, texto/imagem e remete a qualquer fragmento verbal ou imagético integrado em um novo conjunto.

O processo da escrita é visto, sob o prisma da intertextualidade, como resultante do processo de leitura de outros textos ou paratexto. Isso pode ser observado nas Canções sem metro publicadas em livro. Ali, dentre os oito textos que selecionamos para análise, sete deles trazem uma epígrafe, cuidadosamente escolhida por Pompéia, pois a leitura dessa amostragem de paratexto contribui para o estudo de sua linguagem poética, indicando-nos a sua visão de mundo.

De acordo com (CARVALHAL, 1992), o exame das relações que os textos tramam entre eles, o estudo do trabalho de transformação e assimilação de um ou vários textos por um texto centralizador, permite questionar as razões que levaram o autor do texto a reler, reescrever, copiar ou relançar no seu tempo, textos anteriores, refletindo sobre o novo sentido que o autor lhes atribui com esse deslocamento.

Lembramos que a prosa poética de Pompéia se assemelha muitas vezes a instantâneos fotográficos, pequenas pinturas de fatos, situações ou personagens. Portanto, há de se ressaltar a idéia original do poeta e sua peculiar inclinação às artes visuais. Sua escritura-imagem cria mundos cosmogônicos condizentes com a busca metafísica do escritor, às vezes despertando no leitor a sensação de embriaguez ante a percepção de um outro mundo que, de certo modo, supera o mundo real e satisfaz o nosso anseio de ir além da realidade. Então sua prosa poética mostra-nos exatamente este processo de captura perceptiva da realidade na forma de iluminuras, mesmo fazendo uso apenas da linguagem literária que em sua genialidade é extremamente pessoal.

Bartholo (1973) diz que um lado do talento de Pompéia permanece quase desconhecido: o artista plástico que existia nele e que, como o ficcionista, também não pôde se desenvolver. Estudiosa da vida e da obra do escritor, Therezinha Bartholo fala justamente desse aspecto raras vezes abordado, enriquecendo o seu artigo com desenhos inéditos de Pompéia, descobertos no curso de suas pesquisas.

A pesquisadora acrescenta que ele foi um dos escritores de maior característica pessoal em nossa literatura, tendo sido também desenhista e caricaturista de alto nível. Tal pendor parece ter sido um dos seus grandes interesses e, ao mesmo tempo, distração freqüente de 
Pompéia, pois até conversando com amigos, ele desenhava em qualquer papel que lhe estivesse às mãos.

Seus desenhos mais conhecidos são os que ilustram o romance $O$ ateneu, e figuram em todas as edições da Livraria Francisco Alves. Para as Canções sem metro também fez ilustrações, mas, lamentavelmente, até agora não se publicou edição em que essas peças estejam reunidas aos poemas, a não ser as dez publicadas em A Galeria Ilustrada, e constantes dos anexos desta pesquisa.

Além dos trabalhos executados especialmente para suas obras literárias, o escritor desenhou em dois exemplares de Pampanos, livro de poemas de Rodrigo Otávio, seu grande amigo. Um deles, Pompéia ofereceu ao poeta. Contém 30 desenhos a lápis e esfuminho e 10 esboços. Inspirados nos versos, os desenhos são delicados e de grande beleza. O vigor do traço se ajusta aos temas com leveza e desembaraço, e esse conjunto parece constituir a melhor documentação, de que se tem notícia, devido à carga poética que ele colocou em suas manifestações gráficas.

Do outro volume de Pampanos, sabemos que os trabalhos são a bico de pena, com tinta vermelha. Possui menor número de ilustrações e pertenceu ao próprio autor de $O$ ateneu e das Canções sem metro. Pompéia também representou Rodrigo Otávio em caricatura e desenho. Num desses trabalhos, vê-se o poeta sentado à frente de alguns livros, a lira em último plano. O desenho, a lápis, e a figura de um velho de casaco, em bico-de-pena, pertencem ao arquivo da Sra. Laura Rodrigo Otávio, conforme Bartholo (1973). No mesmo arquivo, há pequeninos desenhos com representações de livros abertos e amontoados, figuras humanas, aves, animais, borboletas, que foram improvisados a tinta pelo autor das canções, na folha de rosto do livro Teses e Dissertações, de Antonio Dino da Costa Bueno, Tipografia do Correio Paulistano, São Paulo, 1878.

O anjo que empunha uma flama é desenho a lápis, executado pelo romancista na página em branco anteposta à folha de rosto do livro Histoire de la Littérature Brésilienne, de Ferdinand Wolf, que pertenceu a Pompéia e tem sua assinatura. Na última página, o exemplar contém ainda outro desenho, inacabado, a tinta: cabeça e tronco de mulher, com vestido de gola alta e peitilho, à moda da época. Também o livro Mythologie Figurée de la Grèce, de 
Collignon, guarda a assinatura de nosso escritor; na página anterior ao índice, um esboço de frontaria, em ligeiros traços, parece ser devaneio do autor das Canções sem metro.

É evidente que Pompéia gostava de desenhar em livros, o que faz supor a existência de outros desenhos do romancista nas obras que compuseram sua biblioteca, infelizmente dispersada tempos depois do desaparecimento do escritor. Bartholo baseia a hipótese no fato de conterem desenhos de sua autoria três volumes que lhe pertenceram: os dois indicados e uma Bíblia Sacra, edição da Vulgata, 1860 - livros que chegaram ao seu alcance pela mão de pessoa da família de Pompéia. Entre os livros que pertenceram a Raul Pompéia encontra-se uma Bíblia Sacra Vulgatae Editionis Sexti V e Clementis VIII, publicada em Lyon e Paris, no ano de 1860.

Evidentemente, o fato de esse volume ter pertencido ao escritor é fundamento para asseverar que Raul Pompéia foi um leitor da Bíblia. O livro era dele, apresenta sua assinatura e, ao alto da falsa folha de rosto, tem o número 313, escrito a mão, o que parece indicar uma referência da biblioteca do escritor. Mas além dessas informações, o volume contém inegáveis indícios, melhor dito, provas, pelas quais se percebe nele um livro que recebeu carinho especial do proprietário e que deve ter sido manuseado freqüentemente.

Segundo Bartholo (1973), Pompéia, além de escritor, foi exímio desenhista e se comprazia em ilustrar de mão própria os livros de que gostava. Talvez para ele o desenho representasse uma forma de contemplar visualmente a expressão escrita. E em sua obra deixou dois exemplos bem significativos desse gosto. Depois de refundir em grande parte o texto do romance $O$ Ateneu, executou uma série de desenhos para ilustrá-lo, e o livro, contendo reproduções desse trabalho, como se sabe, foi editado pela Livraria Francisco Alves. Para ilustrar suas Canções sem metro fez também pinturas que só foram reproduzidas em pequeno número com os dez textos editados pela Galeria Ilustrada e a maioria continua desaparecida até agora.

Entretanto, a respeito dessas ilustrações, seu contemporâneo e amigo Rodrigo Otávio dá informações fidedignas no seguinte trecho: 
Dos seus trabalhos, porém, a obra-prima, aquela que, por certo mais amava, é o livro das Canções sem Metro, em cujo lavor o artista trabalhava desde 1883, quando se encontraram em São Paulo, Pompéia, como terceiro anista, e Rodrigo Otávio, calouro. Constituíam, a princípio, pequeninas histórias, uma impressão apenas, uma simples mancha - subordinada cada uma ao sentimento que na imaginação popular corresponde a cada cor do espectro: verde, esperança; amarelo, desespero; azul, ciúme; e para cada conto minúsculo, Pompéia havia pintado a pastel um pequeno quadro com uma cena característica, onde predominava a cor respectiva. (BARTHOLO, 1973).Todos os desenhos foram feitos e é lamentável que tudo se houvesse perdido.

Mas Raul Pompéia não fazia ilustrações apenas para as próprias obras literárias. Alguns outros livros que compunham sua biblioteca, ou as de amigos, também mereceram desenhos. E, pelo que é lícito concluir, são todos eles livros que nosso romancista apreciava.Ora, assim sendo, Bartholo não tem dúvida em considerar esse exemplar da Bíblia Sacra que pertenceu ao escritor, como um livro que Pompéia amava, pois a folha de rosto do volume contém desenhos executados com sua pena de tinta roxa, a mesma tinta usada nos manuscritos de algumas obras literárias. A vinheta existente nessa página representa duas figuras de anjos ajoelhados sobre arabescos lado a lado de uma cruz, sobre a qual sustentam pequena faixa onde está impressa a inscrição Spes Unica. Acima da vinheta, Pompéia delineou cerca de 10 figuras de anjos esvoaçantes, nuvens envolvendo a vinheta e os anjos, e, no alto, uma estrela.

O manuseio freqüente do livro é comprovado pelas inúmeras anotações existentes no texto da Bíblia. Além disso, o verso da falsa folha de rosto esta literalmente coberto de linhas manuscritas por Pompéia e a folha final do volume, inserida entre a última página do texto e contra-capa da encadernação, apresenta uma dezena de outras linhas manuscritas com a letra de Pompéia.Afora algumas palavras em português, todas essas anotações foram escritas em latim e sempre com a tinta roxa que Raul Pompéia usava. A crítica ainda acrescenta que deixando de lado a Bíblia Sacra, a sua atenção se fixou na cor dessa tinta que levou a pesquisadora a procurar nas Canções sem metro a significação do roxo, interpretada por Pompéia. A identificação habitual da cor está ligada à tristeza e à religiosidade. O poema tem o título Roxo, Tristeza e começa com a palavra: “Tinta tomada à palheta do ocaso e às flores da morte”. 
Sendo essa a cor preferida para seus manuscritos, corresponderá, talvez, a alguma disfarçada indicação do desejo de Pompéia de impregnar simbolicamente as palavras com a tristeza que talvez o acompanhasse freqüentemente e que ele disfarçava por meio da sátira, às vezes tão causticante nos seus escritos. Ou o uso da tinta roxa foi uma simples escolha de seu gosto apurado de esteta. É preciso lembrar que em fins do século XIX, a tinta roxa era usada com freqüência, não só na troca de correspondência particular, como por autoridades, em documentos da administração pública. O fato pode se comprovado em alguns manuscritos do Ministério do Império, da Procuradoria da Coroa, Fazenda e Soberania Nacional e do Tesouro Nacional: todos eles escritos com tinta roxa. Mas foi principalmente uma carta confidencial do Ministro da Marinha dirigida ao Ministro do Império, e um requerimento ao Imperador, escritos e assinados com tinta roxa, que levam à suposição de que tenha sido de bom gosto, na época, o uso de tinta dessa cor.

Voltando à Bíblia Sacra e ao latim, percebemos que Pompéia fez estudo desse livro, em razão de suas anotações em latim.O desembaraço com que foram escritas essas anotações em língua latina e principalmente o fato de se tratar de uma edição da Bíblia em latim comprovam que Raul Pompéia dominava o idioma bem à vontade. A primeira edição do romance - O ateneu - Tipografia da Gazeta de Notícias, Rio de Janeiro, 1888, possui um índice, em que os capítulos são indicados por títulos. O do nono é His Amor Unus. E várias charges da autoria de Pompéia, executadas em épocas diferentes, possuem legendas em latim, como também muitas de suas epígrafes em Canções sem metro.

As anotações de Pompéia nesse volume da Bíblia Sacra nada informam sobre a finalidade de seu estudo. Mas este é assunto que merece atenção, pois revela uma faceta do espírito do nosso escritor. E, marcando uma página, deixou ainda no volume pequenino pedaço de papel pautado, dobrado duas vezes na mesma direção, com uma das pontas para fora do corte do livro. Ao abrir cuidadosamente o papelzinho, percebe-se que contém, de um lado, rabiscos, e do outro uma caricatura de cabeça humana com tinta roxa. Mais outra marca do escritor nesse precioso volume da Bíblia Sacra.

No Colégio de Abílio, na Rua Ipiranga/Laranjeiras/RJ, onde o romancista iniciou o curso preparatório, o desenho era, possivelmente, uma das disciplinas que mais seduziam o futuro artista. Em O ateneu, há trechos de reminiscências do personagem Sérgio que podem ser tomados como registro do interesse do escritor por essa arte; "Na tabuada e no desenho linear, 
eu prescindia do colega mais velho; no desenho, porque achava graça em percorrer os caprichosos traços, divertindo-me a geometria miúda como um brinquedo; (...)”.

Noutro capítulo, um episódio acontecido com Sérgio focaliza, minuciosamente, o desenvolvimento do gosto do personagem pelo estudo da disciplina:

"Para a exposição dos desenhos foram retiradas as carteiras da sala de estudo, forradas de metim escuro as paredes e os grandes armários”. Sobre este fundo, alfinetaram-se as folhas de Carson, manchadas a lápis pelo sombreado das figuras, das paisagens, pregaram-se nas molduras de friso de ouro os trabalhos reputados dignos desta nobilitação.

Eu fizera o meu sucessozinho no desenho, e a garatuja evoluíra no meu traço, de modo a merecer encômios. A princípio, o bosquejo simples, linear, experiência da mão; depois, os esbatiplanos, muita figurinha vaga de camponesa, lenço em triângulo pelas costas, rotundas ancas, saias grossas em pregas, sapatões em curva, passei ao desenho das grandes cópias, pedaços de rosto humano, cabeças completas, cabeças de corcel; cheguei a copiar com toda a magnificência das sedas, toda a graça forte do movimento, uma cabra de Tibete!

"Depois das distinções do curso primário, foi esta cabra o meu maior orgulho. Retocada pelo professor, que tinha o bom gosto de fazer no desenho tudo quanto não faziam os discípulos, a cabra tibetana, meio metro de altura, era aproximadamente obra-prima. Ufava-me do trabalho. Não quis a sorte que me alegrasse por muito. Negaram-me à bela cabra a moldura dos bons trabalhos; ainda em cima - considerem o desespero - exatamente no dia da exposição, de manhã, fui encontrá-la borrada por uma cruz de tinta, larga, de alto a baixo, que a mão benigna de um desconhecido traçara. Sem pensar mais nada, arranquei à parede o desgraçado papel e desfiz em pedaços o esforço de tantos dias de perseverança e carinho. Quando os visitantes invadiram a sala, notaram na linha dos trabalhos suspensas duas enigmáticas pontas de papel rasgado. Estranhavam, ignorando que ali estava, interessante, em último capítulo, a história de uma cabra, de uma cruz, drama de desespero e espólio miserando de uma obra-prima que fora”.

Herman Lima apud Bartholo (1973) salientou o espírito satírico de alguns desenhos de $O$ Ateneu, especialmente os que representam Aristarco. Seguindo os passos do autor da História da Caricatura no Brasil, lembre-se aqui o desenho que retrata Ribas, e sua descrição, no romance: 
"Ribas, 15 anos, era feio, magro, linfático. Boca sem lábios, de velha carpideira, desenhada em angústia a súplica feita boca, a prece perene rasgada em beiços sobre dentes; o queijo fugia-lhe pelo rosto, infiguardiã do internato. Estas foram caricaturadas verbalmente: "A Melica, a altiva e requebrada Amália, lambisgóia, proporções de vareta, fina e longa, morena e airosa, levava o tempo a fazer de princesa”. Dois grandes olhos pretos, exagero dos olhos pretos da mãe, tomavam-lhe a face, dando-lhe de frente a semelhança justa de um belo I com dois pingos. Por estes olhos e por sobre os ombros que tinha erguidos e mefistofélicos, derramavam-se desdéns sobre tudo e sobre todos”.

A guardiã era “uma velha, mirrada e má, que erigira o beliscão em preceito único e disciplinar, olhos mínimos, chispando, boca sumida entre o nariz e o queixo, garganta escarlate, uma população de verrugas, cabeça penugenta de gipaeto sobre um corpo de bruxa”.

Na imprensa, Pompéia se destacou como caricaturista, nas charges de $O$ Boêmio. Esse era um jornal de estudantes da Faculdade de Direito de São Paulo, que lutava pela abolição da escravatura. A última sátira, violento desenho de revide a ataques do Diário de Campinas, provocou grande reação contra seu autor. Digna de atenção é, ainda, a alegoria feroz, Homenagem a Pombal, que ocupa duas páginas de O Binóculo, e mostra todo o sarcasmo de que era dotado o traço do desenhista.

Nesses trabalhos Pompéia usava o pseudônimo Rapp. Foi assim que também assinou a ilustração da capa de Vergastas, livro de poemas de Lúcio de Mendonça, editado pela Tipografia e Litografia de Carlos Gaspar da Silva, Rio de Janeiro, 1889. Menos conhecido, porém, é seu desenho estampado na capa do romance Casa de Pensão (Tipografia Militar de Santos e Cia., 1884) de Aluízio de Azevedo. E embora não seja a feição de desenhista o traço principal da complexa e angustiada personalidade de Raul Pompéia, é de justiça assimilar que nele o desenhista enriqueceu esteticamente a imagem do escrito. Pompéia usou vários pseudônimos ao longo de sua produção literária ligada á imprensa do século XIX. Durante a pesquisa que efetuamos pudemos ter acesso a alguns: as iniciais, RP, Fabrício e Procópio. Esses dois nomes ele usou em seus primeiros escritos. Procópio foi um escritor clássico, historiador grego conhecido por ter revelado os escândalos da corte em seu tempo. Fabrício foi um cônsul romano famoso por sua maneira de ser simples e direta numa época em que a pretensão e a hipocrisia reinavam. 
É importante lembrar que a prosa poética de Pompéia se assemelha muitas vezes a instantâneos fotográficos, pequenas pinturas de fatos, situações ou personagens. Portanto, há de se ressaltar a idéia original do poeta e sua peculiar inclinação às artes visuais. Sua escritura-imagem cria mundos cosmogônicos condizentes com a busca metafísica do escritor, às vezes despertando no leitor a sensação de embriaguez ante a percepção de um outro mundo que de certo modo supera o mundo real e vai ao encontro do anseio do leitor de ir além da realidade. Sua prosa poética mostra-nos exatamente este processo de captura perceptiva da realidade na forma de iluminuras.

O livro Canções sem metro nunca foi publicado com as gravuras feitas pelo próprio autor e das quais ele tanto se orgulhava. Isto só aconteceu na mencionada revista: A Galeria Ilustrada, em que constam dez textos ilustrados e fornecidos pelo próprio escritor. O único volume encontra-se no Museu Neo-Pitagórico que o cedeu gentilmente, em 1979, à Biblioteca Pública do Paraná que pôde produzir uma edição Fac-similar da Revista, publicada em Curitiba (1888-1889) e à qual tivemos acesso.

A edição de A Galeria Ilustrada (1888-1889) constitui relevante feito cultural devido a diversos aspectos: órgão da litografia do comércio, pioneira no Paraná, uma vez que seu cuidado gráfico era ampliado pelo funcionamento de um atelier responsável pela formação dos primeiros litógrafos brasileiros; por trazer colaborações de artistas e intelectuais como Nestor de Castro, Silveira Neto, Rocha Pombo, Chichorro Júnior, além de contar com autores nacionais como Raul Pompéia, Valentim Magalhães, Alberto de Oliveira, Virgílio Várzea, entre outros. A reimpressão da revista mostra a qualidade literária de alguns textos, a pertinência das ilustrações, assim como charges políticas da época. Portanto, sua importância pioneira traz contribuições em diversas áreas: gráfica, histórica, documental e artístico-literária em sua dupla função, isto é, a imprensa e a ficção do século XIX.

A Gazeta das Notícias, jornal que rivalizaria com o Jornal do Commercio a partir da fundação, em 1875, também adere ao modismo, publicação de romances, que atraia o publico leitor, como hoje o faz a telenovela. Entre outras obras, publica em folhetins - O ateneu, de Raul Pompéia, e Os Três Mosqueteiros, de Alexandre Dumas, esta em 1877.

De Raul Pompéia : "As Jóias da Coroa", Gazeta Rio, a partir de 30 março de 1882. "O Ateneu", Gazeta de Notícias, de 8/4/1888 a 18/5/1888. 
Vejamos com foi publicada a notícia da morte de Pompéia em 25 de dezembro de 1995.

Raul Pompéia suicida-se. Figura destacada da geração que deu grandes valores, Pompéia colaborara, sob o título “Aos Domingos”, e, depois, “Lembranças da Semana”, substituindo o “Microcosmo” de Carlos de Laet. Espírito inquieto e vibrante, afirmara-se, em 1888, com o Ateneu, e batera-se pela Abolição e pela República. Florianista exaltado defendeu as posições do governo com o mesmo ardor com que se batera pelo novo regime (SODRÉ, 1999, p. 265).

No ano seguinte à sua morte desaparecem alguns jornais, em meio a grande tumulto político. A Liberdade, o Apóstolo, a Gazeta da Tarde são empastelados. Todo o material trazido à praça pública transforma-se em fogueira.

Entre as inovações de nossa imprensa no início do século XX, com relação à literatura podemos distinguir as seguintes: a decadência do folhetim, que evolui para a crônica de uma coluna, focalizando apenas um assunto, e daí para a reportagem; o emprego mais generalizado da entrevista, muito pouco utilizada até 1900, e a crítica literária em caráter mais regular e permanente.

A Revista A Galeria Ilustrada surge em 1888, no Paraná, seguindo os moldes das revistas européias da época, e perfaz um total de dezessete publicações, entre 20/11/1888 e 20/07/1889. Em seu primeiro número traz uma coluna intitulada A Opinião, em que o projeto de seu perfil é descrito.

O texto pede a atenção do público, prometendo atuar na área do jornalismo moderno de sua época e cumprir seu papel na liça das grandes questões que revolucionavam aquele final século, fazendo alusão ao período de transições vivido pela literatura e pelos costumes populares. Apresenta, em seguida, um programa de execução visando ao progresso daquela província nascente. Esse programa faz menção ao gênero inovador da revista, sem intuito de se afastar das normas até então adotadas pela imprensa brasileira. Esclarece que a revista será um jornal do tipo europeu, apresentando aos seus leitores páginas ilustradas com paisagens e retratos de pessoas célebres, do país e do estrangeiro, assim como o relato de acontecimentos locais, exibindo ao mesmo tempo textos variadíssimos, sobre literatura e notícias. Acrescenta que não está filiada a qualquer escola política, mas pretende advogar a causa do bem geral, e, evitando analisar a forma e o proceder político do governo, fará uso da linguagem respeitável, o mais culta possível.

Diz, ainda, que estudará os costumes sociais pelo viés crítico, combatendo os vícios que possam ter fatais conseqüências futuras. Apresentará uma resenha dos fatos ocorridos dentro e 
fora do império, trazendo um noticiário esclarecido sobre o assunto. Renderá homenagem ao mérito, quando esse de fato se manifestar, eliminando os caracteres pervertidos que porventura queiram atuar na sociedade. Nessa difícil empreitada conta com a colaboração de notáveis escritores nacionais que estejam prontos a aceitarem o apelo, trabalhando com denodo no ciclo dessas ardentes aspirações. Termina a descrição do perfil da revista afirmando a necessidade do auxílio do público e de outros periódicos para que seu intento seja bem sucedido.

A Galeria Ilustrada está encadernada, em um único volume, com todos os fascículos publicados de novembro de 1888 a julho de 1889. Ela foi programada para publicação a cada dez dias, nos dias 10, 20 e 30 de cada mês, mas o editor pede desculpas pelo atraso de alguns números, sobretudo no primeiro semestre de 1889.

No século XIX os jornais foram muito influenciados pela vida cultural do país. É nesse período que aparece o romance-folhetim. Sabemos que obras de grandes autores europeus e brasileiros foram publicadas dessa forma.

O século seguinte for marcado por suas grandes guerras e o número de jornais publicados diminuiu bastante, assim como suas tiragens. E o jornal fica atrás de outras mídias, como a televisão e a imprensa áudio-visual. Alguns jornais criaram um suplemento literário, considerado artigo de luxo pela empresas jornalísticas. Segundo Travancas (2001), o homem moderno tem pressa, pouco tempo disponível e quer saber o máximo de informações no menor tempo possível. As empresas jornalísticas, hoje, não têm mais o aspecto amador nas suas estruturas e nem o literário em seus textos. Do século XVIII até meados do século XX, a imprensa brasileira pode ser caracterizada como literária, devido a três fatores: a publicação freqüente dos romances-folhetins, a apresentação de um estilo de texto sem a objetividade e concisão marcantes do jornalismo atual e, sobretudo, por estimular e divulgar a produção literária da época.

Para Amoroso Lima (apud TRAVANCAS, 2001), a relação entre literatura e jornalismo é muito íntima e uma das diferenças está no fato de que na literatura a palavra é um fim e no jornalismo ela é um meio. Para Olinto (1968) apesar de a linguagem da imprensa sofrer todas as contenções fundamentais à pratica do jornalismo, ela é um ato de criação e nesse ponto se aproxima da literatura.

E para finalizar este capítulo apresentamos comentado um dos dez textos da revista $A$ Galeria Ilustrada, edição (1979). 


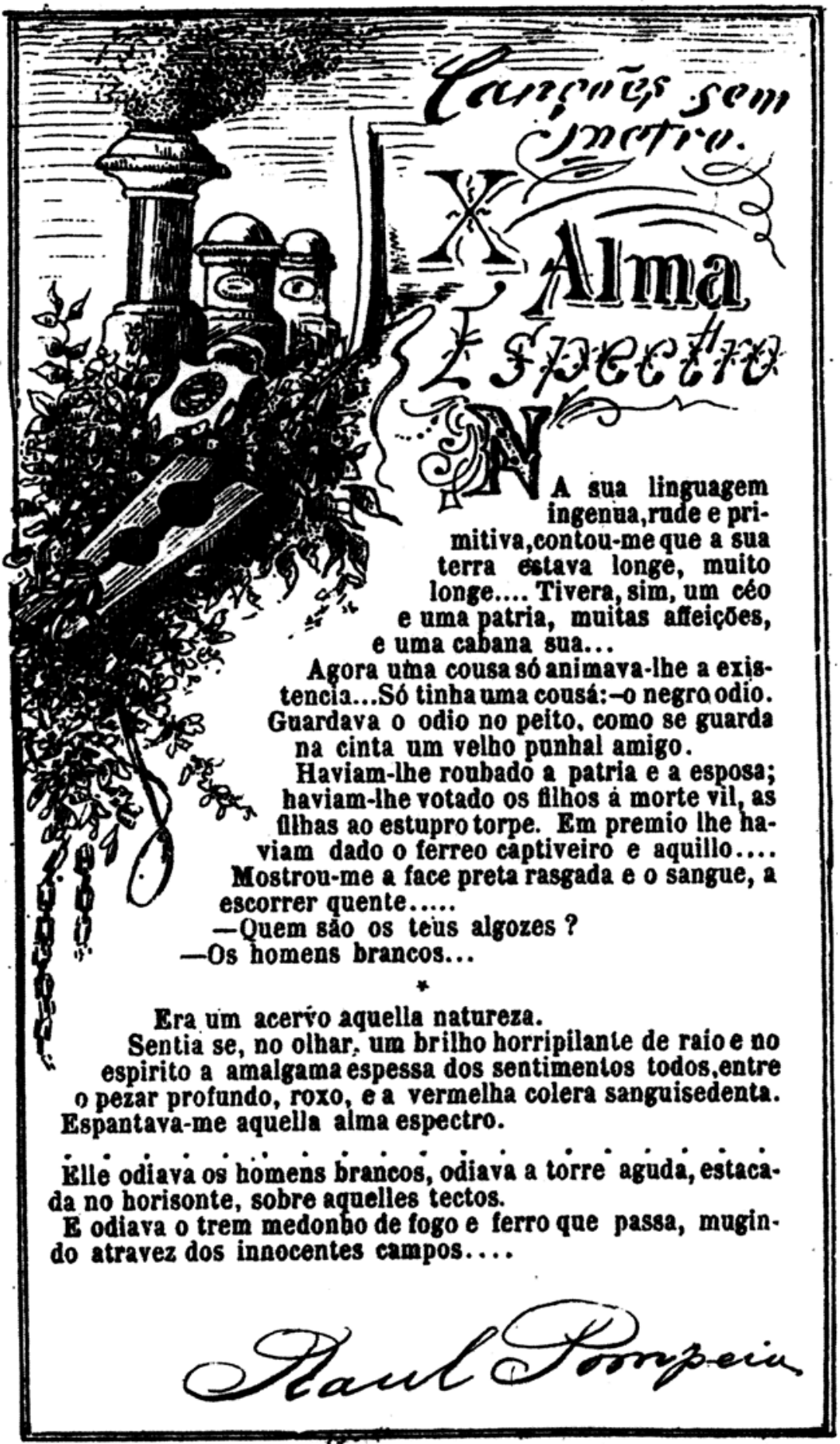

Figura 1: Canções sem Metro: Alma Espectro.

Fonte: Revista A Galeria Illustrada, n. 84, 10 abr. 1889. 
Na linguagem ingênua, rude e primitiva, contou-me que a sua terra estava longe, muito longe... Tivera, sim, um céu e uma pátria, muitas afeições e uma cabana sua...

Agora uma cousa só animava-lhe a existência... Só tinha uma coisa: - o negro ódio. Guardava o ódio no peito, como se guarda na cinta um velho punhal amigo.

Haviam-lhe roubado a pátria e a esposa; haviam-lhe votado os filhos à morte vil, as filhas ao estupro torpe. Em prêmio lhe haviam dado o férreo cativeiro e aquilo...

Mostrou-me a face preta rasgada e o sangue a escorrer quente...

— Quem são os teus algozes?

— Os homens brancos...

Era um acervo aquela natureza.

Sentia-se, no olhar, um brilho horripilante de raio e no espírito a amalgama espessa dos sentimentos todos, entre o pesar profundo, roxo, e a vermelha cólera sanguesedenta. Espantava-me aquela alma espectro.

Ele odiava os homens brancos, odiava a torre aguda, estacada no horizonte, sobre aqueles tetos.

Ele odiava o trem medonho de fogo e ferro que passa mugindo através dos inocentes campos...

Raul Pompéia.

O texto Alma espectro, publicado em A Galeria Ilustrada com ilustração do próprio autor, em 1889, assemelha-se aos Pequenos Poemas em Prosa, de Baudelaire. Percebemos nos recursos estilísticos do autor traços comuns ao poeta da modernidade, na França.

Primeiramente a brevidade do texto. Também a analogia das cores, "entre o pesar profundo, roxo, e a vermelha cólera sanguesedenta”, o uso dos sentidos e dos símbolos de coisas materiais para expressar sentimentos. Além das cores da natureza, Pompéia encontra espaço em sua paleta poética para as cores que moram nas almas torturadas pela brutalidade, nos seres vencidos pelo cansaço, mutilados pela escravidão, que votam um ódio mortal ao senhor que tolhe sua liberdade. Neles sobrevive o incolor nos sentimentos, cor que não se define. Vale lembrar a cor sem cor do tédio, que habita as criaturas cansadas de viver. 
Na linguagem poética de Pompéia percebemos o recurso da aliteração “estupro torpe”, a repetição de signos, "sua terra estava longe, muito longe”, enumeração, “um céu e uma pátria, muitas afeições e uma cabana sua...”, traços gerais da teoria do impressionismo, Francastel (1974 apud RIBEIRO, 2001), como o registro visual de fenômenos de consciência, “só tinha uma coisa: - o negro ódio. Guardava o ódio no peito, como se guarda na cinta um velho punhal amigo", a busca de equivalente plástico para cada sensação e /ou emoção "odiava a torre aguda”, e o jogo de luzes e sombras.

Observamos, ainda, metonímias, "um céu e uma pátria”, sinestesia, prosopopéias, comparação, neologismo, “sanguesedenta”, o uso expressivo da pontuação e de tempos verbais eruditos, por exemplo, o mais-que-perfeito, “tivera”, que dá idéia de afastamento no tempo passado. Além das cores da natureza, Pompéia encontra espaço em sua paleta para as cores que moram nas almas torturadas pela brutalidade, nos seres vencidos pelo cansaço, mutilados pela escravidão, que votam um ódio mortal ao escravizador, como no exemplo deste texto.

O texto está dividido em três partes: na primeira está a apresentação do sujeito pelo ser de enunciação. As duas últimas partes estão separadas por recursos de pontuação e espaço. Nessas são descritas as sensações e emoções do sujeito por meio de recursos estilísticos.

Na ilustração percebe-se a imagem de um trem em movimento junto a um instrumento de castigo de escravos, envolto em ramos e correntes de ferro. O desenho é litográfico e apresenta-se do lado esquerdo e superior do espaço retangular em que se encontra o texto. $\mathrm{O}$ título “alma espectro" diz respeito à alma (princípio de vida do homem) que perdeu toda a vida, apenas sobrevive, pois se transformou em espectro (fantasma) pela escravidão.

Em relação ao jornalismo, observamos que o texto apresenta um relato piramidal cronológico, com introdução em nível narrativo, desenvolvimento atrativo e desfecho ou culminação concreta. Também a claridade das idéias e a correspondente transparência expositiva. Apesar da brevidade do texto, pregada por Baudelaire, percebe-se densidade, exatidão, precisão de termos, sensatez, naturalidade, ritmo, devido à sua poeticidade, cor, correção, propriedade e originalidade de enfoque, de ponto de vista e de forma, uma vez que é um gênero híbrido, ou seja, prosa poética. Há sinceridade na percepção do eu poético que não falseia a realidade, denunciando o problema da escravidão duma etnia, questão social 
brasileira que Pompéia combateu em seus escritos políticos e também em sua linguagem jornalística e literária. O texto é atraente e desvela uma importante questão para o leitor, projetando uma nova luz sobre o mundo e a vida. Como bom periodista, Pompéia mostra que sabe ver e contar o que vê, trazendo idéias universais e apresentando-as de maneira original e inovadora. 


\title{
3 JORNALISMO E PROSA POÉTICA: ANÁliSE DOS TEXTOS DE $A$ GAZETA DA TARDE
}

Em A Gazeta da Tarde, ano VII, os textos aparecem no período compreendido entre 21 e 29 de janeiro de 1886. Alguns títulos sofrem alterações de uma versão para outra, assim como as epígrafes que são acrescentadas na versão do livro, conforme poderemos observar no próximo capítulo. Listamos, a seguir, textos publicados no jornal. Para cada um deles, existe uma outra versão publicada no livro Canções sem metro, objeto de discussão do próximo capítulo. $\mathrm{O}$ número em algarismo romano foi dado pelo próprio autor para cada uma das publicações no periódico - A Gazeta da Tarde.

\author{
Rumor e Silêncio XXXV \\ Vulcão Extinto XXXVIII \\ Os Continentes XXXIX \\ Os Deuses XL \\ Sic Transit XLI \\ Solução XVIII \\ Tormenta e Bonança XLIV \\ Conclusão XLV
}

Vimos modificações bastante significativas, de uma versão para outra, mas não as atribuímos à diferença de linguagem, usada pela imprensa e pela obra literária, de acordo com os valores de nossa época, uma vez que no século XIX, a literariedade se sobrepunha à comunicação objetiva que atende a demanda, da era da informática, em que hoje se contextualiza.

Todavia, ciente do zelo de Pompéia em relação ao burilamento de seus textos, observamos que, em sua maioria, durante seu processo de revisão, o autor faz várias 
transformações, dando prioridade às palavras nominais, substantivos ou expressões com esse efeito, de modo a acrescentar mais elementos expressos. Este fato contribui para que haja um maior lirismo na edição aprimorada, cujo valor estético aparece cada vez mais preponderante.

Assim, percebemos que o uso de palavras nominais torna suas canções mais sugestivas e com visão mais ampla, de acordo com o sentimento cosmogônico, ou seja, aquele que questiona a formação do cosmos, o que constatamos nos textos em questão. A organicidade das Canções sem metro decorre de uma estrutura que incorpora momentos, isto é, primeiramente, podemos observar uma espécie de impressão inicial, definidora ou questionadora da percepção da realidade que corresponde à presença ontológica e estética do poeta. Em seguida, percebemos o oxímoro do desejo, uma espécie de desvelamento inicial do outro, definição da forma ou da comunicação estética. Depois, apresenta-se a gênese da realidade, visível no processo de criação do poema e a seguir o espírito que anima a realidade e a constatação de que o ato criador produz apenas palavras. Então, o leitor percebe a construção dessa realidade, expressa pelo eu poético em relação ao tempo e ao reconhecimento de um possível desfecho pessimista, vislumbrado no final. Todos estes elementos são traduzidos por um sistema binário e contraditório, segundo Ivo (1963), repetição infinita do oxímoro básico em cada composição. O gênero criado e desenvolvido por Pompéia no ambiente jornalístico constitui verdadeira escritura artística composta pela utilização do contraste. O escritor inaugura novos campos na literatura brasileira, fazendo uso de imagens curiosas e símbolos inusitados, ocultos no âmago de suas canções e esse processo de transfiguração imagística contribui para seu caráter renovador.

\subsection{Baudelaire e Pompéia}

A prosa e a poesia compartilham a mesma natureza, utilizam-se dos mesmos signos, constituem estilizações da realidade e se assemelham em vários pontos. Entretanto, à poesia interessa apenas o mundo interior, o "eu” do poeta, seu objetivo verdadeiro é o reino infinito do espírito. O poeta volta-se para dentro de si mesmo, para as camadas interiores de seu ser, de sua alma, buscando nelas seus sentimentos, suas emoções. Pode-se dizer, portanto, que poesia é a emoção expressa por meio da palavra no texto artístico. Para ilustrar observemos, a seguir, 
um texto poético de Baudelaire, com quem Pompéia manteve prática intertextual: “A Natureza é um templo onde vivos pilares / Deixam filtrar não raro insólitos enredos; / O homem o cruza em meio a um bosque de segredos / Que ali o espreitam com seus olhos familiares./ Como ecos longos que à distância se matizam / Numa vertiginosa lúgubre unidade tão vasta/ Quanto a noite e quanto a claridade, / Os sons, as cores e os perfumes se harmonizam” (BAUDELAIRE, 2002, p.71).

A paisagem exterior só interessa ao poeta como projeção de seu próprio "eu", ou quando aparece interiorizada, ou ainda quando ela desperta certos ecos na alma do poeta, fazendo com que ele saia de dentro de si mesmo, projete-se na natureza para retornar à sua própria alma. No texto que exemplifica percebemos que as imagens abstratas tornam-se mais fortes por estarem interligadas às imagens concretas. As técnicas de sugestão sutil são parte do estilo do autor que sabe usar com maestria as imagens e os símbolos.

Dizei, depois, onde mais intensa é a vida e mais assombrosa,

se embaixo, se lá em cima, no zimbório diáfano desse firmamento

que a noite vai conquistando agora, na savana imensa, onde transitam

os rebanhos das estrelas, onde os meteoros vivem, onde os cometas

cruzam-se como espadas fantásticas de arcanjos em guerra - nesse

discreto abismo habitado pelos astros e pelo silêncio sagrado do infinito.

(Raul Pompéia) - Rumor e Silêncio XXXV.

Ou ainda nesse trecho de outra das canções sem metro, do periódico A Gazeta da Tarde:

À sombra do pico altíssimo, abre-se a cratera.

Rasgam-se precipícios sem fundo. Dominada pela vertigem,

vai-se-nos a imaginação pelas fragas e perde-se na sombra 
impenetrável, lá embaixo. Silêncio medonho.

Antes de tombar sobre o vulcão este silêncio pesado,

quanta vez tremeram estas rochas, ao rugido da lava fervente!

(Raul Pompéia) - Vulcão Morto XXXVIII

Quando aparece na poesia a paisagem da realidade exterior, o mundo subjetivo e objetivo aderem-se, imbricam-se, formando uma só entidade, subjetivo-objetiva, com a predominância do primeiro. "Antes de tombar sobre o vulcão este silêncio pesado, quanta vez tremeram estas rochas, ao rugido da lava fervente!”.

Além dessa distinção, podemos observar que se a linguagem da poesia conserva, até certo ponto, a ordem lógica necessária à inteligibilidade, mesmo que isso não lhe seja essencial, essa ordem lógica é muito mais necessária na prosa, já que ao prosador pode interessar mais, a realidade objetiva, a realidade que o cerca, do que seu mundo interior, caótico e vago. Daí, a razão de o prosador lançar mão da lógica ao produzir sua obra literária, lógica que não existe, necessariamente, na obra poética. Embora tanto o prosador quanto o poeta usem a metáfora, ela pode ser menos vaga, menos ambígua na prosa do que na poesia, pois "a linguagem da prosa retrata, descreve, fixa, narra os aspectos históricos, visíveis, que estão à mercê da observação de todos” (MOISÉS, 1991).

Como dissemos, na introdução, pode-se pensar, equivocadamente, que as estruturas simbólicas sejam meras convenções utilizadas para descrever a realidade. Porém, é óbvio que não há maneira mais completa de apreensão da realidade, senão, por meio do símbolo. O símbolo, como podemos observar nos exemplos de prosa poética, não é arbitrário e reflete autenticamente o que expressa, requisito sem o qual seria impossível qualquer relação ou comunicação. Deve-se ter em mente que a imagem não significa nada além daquilo que efetivamente representa, ao passo que o símbolo pode ser definido como um sinal que representa alguma coisa além do factual e literal. "Pára e retrocede, insensato! Eu venho da grande viagem. Desci ao fundo dos problemas”. Heredia (1979) diz que o homem usa sinais não apenas para a indicação das coisas, mas também para as representar. 
A variedade de imagens combinadas do concreto ao abstrato foi utilizada em profusão no século XIX, tanto por Eça de Queirós, como por Machado de Assis. Pompéia também utiliza esse processo com grande talento, muitas vezes justapondo sutil e criticamente idéias dissociadas: "visitei, com o verme, as entranhas da terra; com o vendaval, os desertos; com o leão, os antros; com a águia, a região das tormentas; com os espectros, o coração da noite; com a estrela, o infinito; com os sonhos, o nebuloso passado!” Aceitando-se que o escritor expõe muito do seu foro íntimo, por meio dos recursos de expressão que ele seleciona para compor as suas canções, o estudo de algumas imagens e símbolos usados por Raul Pompéia poderá desvelar não apenas a natureza de seu estilo, como também determinadas facetas de sua personalidade: “deu-me luz o sol; deu-me vigor o penhasco; deu-me linguagem, o trovão; deume energia o raio; deu-me asas o ciclone; deu-me arrojo o mar!”. Inicialmente podemos perceber que o autor expressa os seus questionamentos, as suas reflexões, a sua cosmovisão, por meio de uma apreensão basicamente visual da realidade e das associações feitas entre os seres, as coisas e a natureza.

A sua linguagem pode aparecer, ainda, de modo contínuo, num ritmo mais natural, mais identificado com o da fala habitual; graficamente se representará preenchendo linhas inteiras da página, como, no exemplo, abaixo. Em que “a grande viagem” é o símbolo metafísico cantado pelo eu poético.

"Pára e retrocede, insensato!

Eu venho da grande viagem.

Desci ao fundo dos problemas; visitei, com o verme, as entranhas da terra; com o vendaval, os desertos; com o leão, os antros; com a águia, a região das tormentas; com os espectros, o coração da noite; com a estrela, o infinito; com os sonhos, o nebuloso passado! Deu-me luz o sol; deu-me vigor o penhasco; deume linguagem, o trovão; deu-me energia o raio; deu-me asas o ciclone; deu-me arrojo o mar! estudei, indaguei, auscutei, interpelei, evoquei, obsecrei, apostrofei, fui da apóstrofe à maldição; da maldição à blasfêmia! aurúspice sacrílego, abri o ventre dos deuses! Sondei, sondei, sondei! Desafiei o gênio negro das metamorfoses; provoquei as vertigens do abismo!...

E o gênio negro respondeu-me:

“Nunca!” 
E eu li no abismo:

"NUNCA!"

Raul Pompéia - Solução XLIII

A prosa, por sua vez, pode aparecer de modo contínuo, formando linhas inteiras, o que não impede que apareçam páginas de prosa poética, como no seguinte exemplo, em que as figuras colorem o texto de poeticidade e o símbolo do sol é reverenciado como divindade, mostrando a visão panteísta do ser de enunciação.

Vê! Teus raios penetraram a natureza como uma vida nova; ao

teu olhar o universo ressurge e rejuvenesce. Ouve! há risos sob

a relva e canções no arvoredo!

É teu o ouro das asas do inseto; o verde dos bosques é teu; é teu

o azul dos espaços. Todas estas pétalas que resplendem iriadas,

recamando os prados, todas elas foram coloridas pelo minucioso

pincel das tua luz.

Que estranha Divindade és tu, glorioso sol, que me deslumbras?!

(Raul Pompéia) - Os Deuses.

Às vezes a poesia faz interferência na prosa, isto é, encontramos passagens poéticas em obras que classificamos seguramente de prosa. Está neste caso o trecho do romance O Ateneu transcrito abaixo: 
"Aqui suspendo a crônica das saudades. Saudades verdadeiramente? puras recordações, saudades talvez, se ponderarmos que o tempo é a ocasião passageira dos fatos, mas sobretudo - o funeral para sempre das horas" (POMPÉIA, R. 1976).

Apesar dessas reflexões introdutórias sobre poesia e prosa, o que nos interessa é a questão de gênero, ou seja, comprovar que Pompéia criou a prosa poética no Brasil, desenvolvendo-a junto ao jornalismo. E remetendo-nos às considerações de Morier (1981), sobre o pequeno poema em prosa, vimos que, em torno de 1840, a idéia do poema em prosa estava no ar, ou melhor, ela se desenvolvia como um novo estilo na literatura e em movimento contínuo. O romantismo encontrou esse gênero misto num meio de expressão de acordo com suas tendências, pois repetimos que o romantismo e o poema em prosa têm em comum: o gosto pela harmonia, pela mistura de gêneros, pela variedade, pelo movimento e o gosto pela liberdade e pelo idealismo.

Charles Bruneau reconhece que Aloysius Bertrand inspirou Baudelaire. As dimensões do poema em prosa diminuem, ou seja, o texto é dividido em seções e cada uma delas se apresenta como uma pequena pintura, tendo sua própria unidade. Com Bertrand, o pequeno poema em prosa atinge a forma mais bem definida, ocupando o tamanho de uma página de texto compacto, mas repartido em unidades, ele se estende a cerca de duas páginas impressas. Bertrand é o criador de uma forma delicadamente nuanceé, em que as palavras apresentam uma língua harmoniosa e um sentido poético real e acoplam no interior de páginas vivas e preciosas como as iluminuras. Percebe-se a essência poética em suas composições. Guérin faz uso de uma fórmula menos rigorosa, mas acrescenta ao poema em prosa determinados fechamentos periódicos com refrão. Desde então cultivaram duas formas, a prova cadenciada poética e o poema em prosa que se desenvolveram paralelamente. O poema em prosa é mais musical e mais organizado. Em alguns casos, a combinação de semelhança fonética parcial e a disparidade sêmica provocam um efeito inusitado, a surpresa ou estranhamento, frases curtas que provocam movimento em contraposição às orações nominais que predominam na descrição da paisagem passiva que assiste às ações do tempo implacável.

A prosa poética trouxe à poesia do século das luzes sua cadência métrica monótona, seus clichês, seus sinônimos de estilo e as perífrases do estilo nobre. Corinne (1807) de M. de 
Staël, com seu material carregado de interrogações, de oratória, de exclamações frias, de invocações e prosopopéias. Saint Beuve teve o mérito de romper com o estilo convencional dessa corrente literária e a prosa poética acaba-se separando do estilo nobre.

O pequeno poema em prosa derritmado constituía o objetivo de Baudelaire. Ele confessa que após várias leituras do famoso Gaspard de la nuit tem o desejo de tentar algo análogo. E ele sonha com as irregularidades interiores: "quem, diz ele, nunca sonhou com uma prosa poética musical, sem ritmo e sem rima, bastante capaz de se adaptar aos movimentos líricos da alma, às ondulações da imaginação, aos sobressaltos da consciência?” (MORIER, 1981, p. 938-47, tradução nossa).

Morier fala das várias manifestações do poema em prosa. A mais antiga seria a prosa cadenciada, usada nas ladainhas religiosas. Nesta forma Marmontel escreveu Lês Incas, (1777), com 661 páginas, divididas em dois volumes. Depois, uma outra modalidade de prosa poética, repleta de exclamações iniciais, com intonações oníricas e tom bem musical, composta por Rosseau, entre outros. Essa manifestação constitui-se de prosa poética cadenciada junto a um sentimento ou ao estado de alma, ao sonho, à impressão difusa e ao abandono do ser às forças da natureza (p. 939). A seguir aparece o grande poema em prosa, difundido por Marmontel, citado anteriormente, Chateaubriand (Les martyrs) e Fénélon que deve ter lançado essa modalidade compondo Le Télémaque, romance idealizado, com heróis da mitologia no reino da Utopia, exibindo paisagem edênica, poema épico e lírico ao mesmo tempo, cheio de pompa e grandiloqüência. Guérin faz uso de vozes paralelas e suas composições apresentam estribilho, aliterações, assonâncias, cadência métrica monótona, clichês, interrogações oratórias, exclamações frias, invocações, sinônimos de estilo e prosopopéias. Na análise dos textos, veremos que as canções de Pompéia apresentam muitas dessas características. Então, a prosa poética se separa do estilo nobre e o lirismo alia-se ao tom satírico, sendo menos fatigante.

Com Lamennais surge uma forma intermediária, situada a meio caminho entre a prosa poética e o pequeno poema em prosa ritmada. Há ainda manifestações de prosa cadenciada corrente, na segunda metade do século XIX e também prosa rimada de Bruneau e elas têm em comum o movimento ambicionado por Baudelaire. 
Vamos perceber que a prosa poética pode apresentar-se composta de mitos, de contos, provérbios, clichês, anotações, aforismos, epigramas, crítica, anedota, citações, reflexões, digressões metafísicas. A sua identificação com o modernismo constitui-se de simplicidade, anti-parnasianismo, metalinguagem crítica, surrealismo, humor, humor negro, trocadilho, a paródia. A prosa poética caracteriza-se pela estética do fragmento e constitui a desmistificação do poético em intensa rede intertextual, como se percebe com a presença de várias artes. Mas resumindo as características apresentadas no desenvolvimento da prosa poética no exterior, percebemos que ela traz em essência o desejo de liberdade de criação.

Sabemos que Pompéia teve influência literária de Baudelaire (1821-1867) e as semelhanças entre os dois autores podem ser percebidas, conforme demonstramos. Uma característica fundamental de Baudelaire é sua disciplina espiritual e a clareza de sua consciência artística. Ele reúne o gênio poético e a inteligência crítica. Suas idéias acerca do procedimento da arte poética estão no mesmo nível de seu próprio poetar e são, em muitos casos, até mesmo mais avançadas A epígrafe do texto inicial das Canções sem metro, publicada pelos amigos de Pompéia, em 1900, constitui índice de sua filiação estética, pois é o famoso poema de Baudelaire, Correspondences, que integra a obra Les Fleurs du Mal.

Fora da França, Põe (1809-1849) foi quem separou, de modo mais resoluto, em termos de técnicas composicionais, a lírica e o coração. Desejou como sujeito da lírica uma excitação entusiástica, mas que esta nada tivesse a ver com a paixão pessoal nem com a chamada embriaguez do coração. Entende, por excitação entusiástica, uma disposição ampla, chama-a de alma, apenas para dar-lhe um nome, porém acrescenta cada vez: “não coração”. Baudelaire repete as palavras de Poe quase ao pé da letra, variando-as com formulações próprias: “A capacidade de sentir do coração não convém ao trabalho poético”, em oposição à “capacidade de sentir da fantasia” (apud FRIEDRICH, 1978, p. 37). A filosofia dessa arte poética não é concluir, mas romper. Deve-se reparar também na dissonância entre o modo de expressar e o que está expresso. Pompéia o faz por meio de idéias contraditórias, os oxímoros, de que falamos na análise dos textos.

O texto/imagem a seguir constitui um retorno à prosa, à narrativa, inspirado nos Pequenos poemas em prosa, de Baudelaire. O texto é apresenta a brevidade baudelaireana, traz um pequeno relato enxertado de poeticidade, percebida na seleção vocabular, na combinação sintagmática, “expansão ardente, auroreal do amor” na escolha de símbolos 
coloridos, “o mato verde bordado pelas flores da aleluia... belas flores douradas!”, em que o visual aparece preponderante.

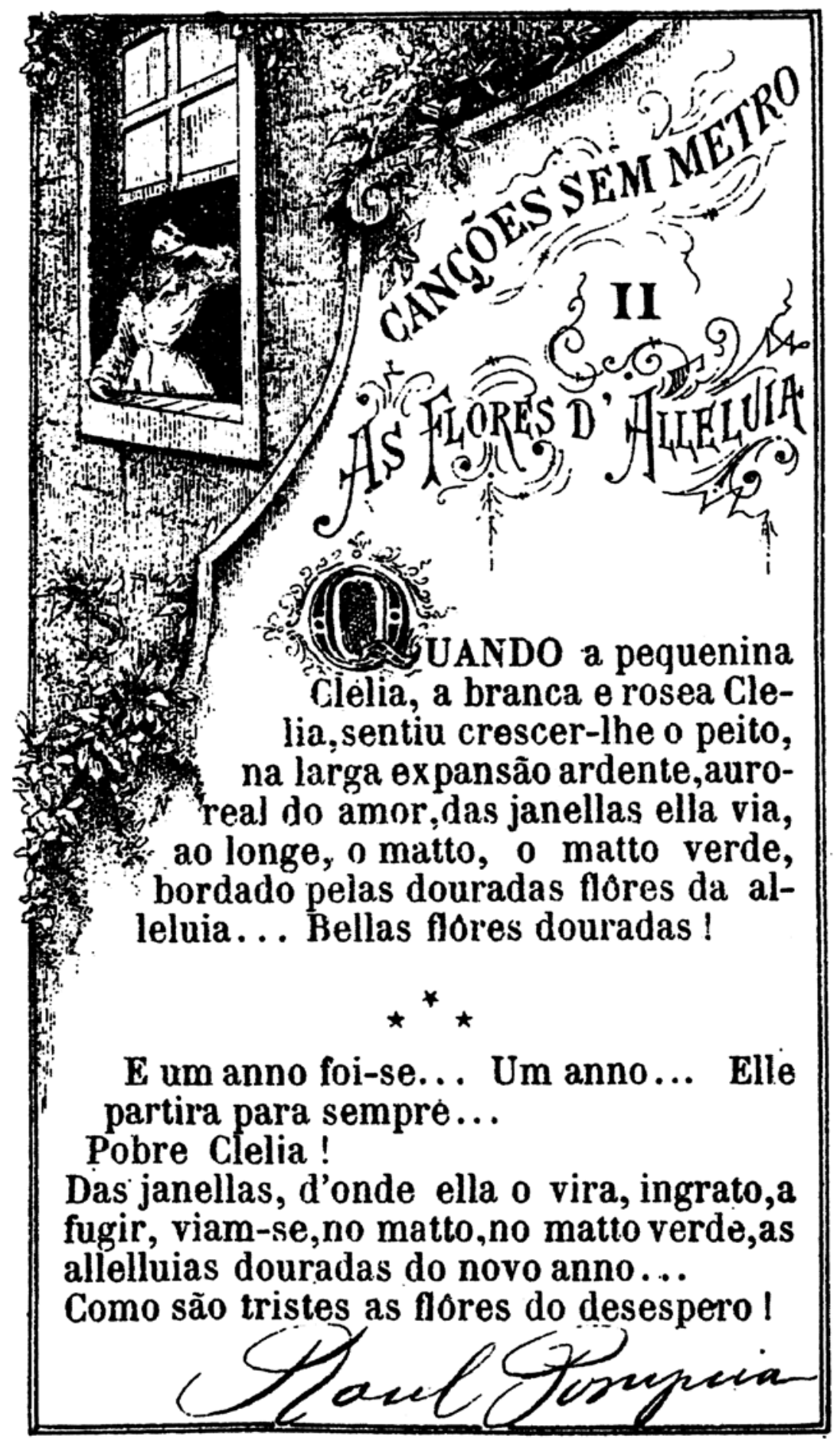

Figura 2: Canções sem Metro: As flores D’Aleluia.

Fonte: Revista A Galeria Illustrada, n. 12, 30 nov. 1888. 
“Quando a pequenina ‘Clélia, a branca e rósea Clélia, sentiu crescer-lhe o peito, na larga expansão ardente, auroreal do amor, das janelas ela via, ao longe, o mato, o mato verde, bordado pelas douradas flores da aleluia... belas flores douradas!

E um ano foi-se... Um ano... Ele partira para sempre...

Pobre Clélia!

Das janelas, donde ela o vira, ingrato, a fugir, viam-se, no mato verde, as aleluias douradas do novo ano...

Como são tristes as flores do desespero!”.

(Raul Pompéia. As flores da aleluia II. In: A galeria Ilustrada. Curitiba, PR, ano I, n. 2, 30 nov. 1888).

Vejamos um exemplo de um dos Pequenos poemas em prosa, de Baudelaire, para observação das semelhanças e dessemelhanças entre os dois autores - Baudelaire e Pompéia.

\section{O Galante Atirador}

A CARRUAGEM atravessava o bosque, quando ele a fez parar nas proximidades de um stand de tiro, dizendo que the seria agradável atirar algumas balas para matar o Tempo. Matar esse monstro não é a ocupação mais comum e mais legítima de cada um de nós? E ele, galantemente, ofereceu a mão à sua querida, deliciosa e execrável mulher, a essa misteriosa criatura a quem deve tantos prazeres, tantas dores, e talvez também grande parte do seu gênio.

Diversas balas foram ter longe do alvo; uma delas chegou a penetrar no teto; e, como a encantadora mulher ria loucamente, zombando da inabilidade do esposo, este se voltou de súbito para ela e disse-lhe:

— Veja aquela boneca, ali, à direita, de nariz no ar e de aparência tão soberba. Pois bem, caro anjo, faço de conta que é você.

E fechou os olhos e puxou a gatilho. A boneca ficou inteiramente decapitada.

Então, inclinando-se para sua querida, sua deliciosa, sua execrável mulher, sua inevitável e implacável Musa, e beijando-lhe com respeito a mão, acrescentou:

— Ah! meu caro anjo! quanto lhe sou grato pela minha habilidade! (BAUDELAIRE, 1995, p.331). 
Esse pequeno poema em prosa de Baudelaire traz características básicas do gênero híbrido proposto pelo autor. É bastante breve e de leitura atraente. O texto pode ser dividido em três partes. Na primeira, o ser de enunciação introduz o modo narrativo, situando o tema do texto. No desenvolvimento, o eu poético pára em um stand de tiros de perde as balas ante a zombaria da esposa. O final é surpreendente. De olhos fechados e apontando uma boneca que simbolizaria a amada, ele acerta o tiro e a peça é decapitada. Então, ironicamente, ele agradece a sua “querida execrável” por sua habilidade.

Aparecem recursos estilísticos como a ironia, “- Ah! meu caro anjo! quanto lhe sou grato pela minha habilidade!”, as antíteses, “querida, deliciosa e execrável mulher”, metáforas, “para matar o tempo”, repetição, “tantos prazeres, tantas dores”. O eu poético provoca a atenção do leitor fazendo uso do diálogo ou função fática.

Em relação à prosa poética, lembramos que, a partir do final do século XIX, essa forma híbrida pode ser encontrada. Então, a prosa literária e a poesia coexistem como prosa poética. ou poemas em prosa em vários enunciados textuais. Comprovamos com as Canções sem metro, de Pompéia, ou os Pequenos poemas em prosa, de Baudelaire. Naquele século XIX, no continente europeu, o escritor francês elaborou, na teoria e na prática, o poema em prosa, assim como Raul Pompéia o fez no Brasil.

\footnotetext{
"Qual de nós não sonhou com o milagre de uma prosa poética, musical sem ritmo e sem rima, bastante maleável e rica de contrastes para se adaptar aos movimentos líricos da alma? (...) É, sobretudo, da frequentação das grandes cidades, é do cruzamento de suas inúmeras relações que nasce este ideal obsessivo" (BAUDELAIRE, 1995, p. 979).
}

Naturalmente pelo fato de Baudelaire haver traduzido Poe e levado seus princípios de composição literária para a Europa, percebe-se em ambos a fonte inspiradora que veio coadunar com suas preferências literárias que se encontravam em estado ainda latente. Poe define a poesia como uma criação rítmica da beleza, ou seja, “a poesia é a meta de toda arte superior e o único meio de atingir o belo”, Baudelaire (2002). Pompéia compartilha com Baudelaire, o chamado poeta da modernidade, a capacidade de ver no deserto da metrópole 
não só a decadência do homem, mas também de pressentir uma beleza misteriosa, não descoberta até então. Pompéia, assim como Baudelaire, jamais tiveram pressa em publicar seus poemas que foram escritos, reescritos, alguns provavelmente destruídos, fundidos, refundidos e burilados cuidadosamente por muitos anos.

Como já dissemos, os pequenos poemas em prosa de Baudelaire assemelham-se aos textos que Pompéia denomina de microscópicos e compartilham a semelhança da forma de os Pequenos poemas em prosa, além da temática. Podemos citar: O estrangeiro, Desespero da velha (BAUDELAIRE, 2002, p. 279) e “Anywhere out of the world” (em qualquer lugar fora do mundo, p. 336-7), dentre tantos outros, que transcrevemos abaixo.

ANYWHERE OUT OF THE WORLD (Seja onde for - fora do mundo)

ESTA VIDA é um hospital onde cada enfermo vive ansioso por mudar de leito. Este desejaria sofrer diante da lareira; aquele que se curaria ao lado da janela.

Tenho a impressão de que estaria sempre bem lá onde não estou, e este problema de mudança é um dos que eu discuto sem cessar com a minha alma.

-Dize-me, ó minha alma, pobre arrefecida, gostaria de habitar Lisboa? Lá deve fazer calor, e tu te refestelarias como um lagarto. É uma cidade à beira da água; dizem ser construída de mármore, e que seu povo odeia tanto o vegetal que arranca todas as árvores. Eis aí uma paisagem conforme ao teu gosto; paisagem feita com a luz e o mineral, e o líquido para refleti-los!

Minha alma não responde.

— Visto que és tão amiga do repouso, com o espetáculo do movimento, queres vir habitar a Holanda, essa terra de bem-aventurança? Creio que te divertirás nessa região, cuja imagem tantas vezes admiraste nos museus. Que pensarias de Roterdã, 'tu que amas as florestas de mastros e os navios atracados junto às casas?

Minha alma permanece muda.

— Porventura a Batávia te sorriria mais? Lá encontraríamos o espírito da Europa casado à beleza tropical.

Nem uma palavra. Minha alma estaria morta?

— Então chegaste a um grau de entorpecimento em que só te comprazes com o teu próprio mal? Se assim é, fujamos para as terras que são as analogias da Morte... Já sei o que nos serve, pobre alma! Preparemos 
as malas para Tornéu. Vamos ainda além, ao extremo do Báltico; ainda além da vida, se é possível; vamos viver no pólo. Lá o Sol apenas roça de soslaio a Terra, e as lentas alternativas da luz e da noite suprimem a variedade e aumentam a monotonia, essa metade do nada. Lá poderemos tomar longos banhos de trevas, enquanto, para nos divertirem, as auroras boreais nos enviarão de quando em quando os seus feixes róseos, como reflexos de um fogo de artifício do Inferno!

Por fim, minha alma explode, e sabiamente me grita:

— Seja onde for! Desde que fora deste mundo! (BAUDELAIRE, 1995, p. 336-7).

O texto apresenta brevidade e características românticas (como a evasão do tempo/espaço), aliadas ao simbolismo (substantivos em letras capitais). Os termos: "pobre arrefecida”, “amiga do repouso", "permanece muda”, "estaria morta”, "pobre alma”, são denominações que o eu poético dá à sua alma. "Auroras boreais” e "feixes róseos” também são heranças do romantismo. Há um certo tom de moralidade e muita ironia e o desfecho nada tem a ver com o romantismo. "Por fim, minha alma explode, e sabiamente me grita: - Seja onde for! Desde que fora deste mundo!” O sol também cultuado por Pompéia tem realce no texto, estabelecendo reação de contradição com a terra, ambos os signos em maiúsculas, pela influência simbolista.

Pelo fato de nossa preocupação principal estar ligada à construção de um gênero inovador no Brasil, a prosa poética das canções de Pompéia ligadas ao jornalismo e à literatura, chamamos a atenção para aspectos semelhantes entre os textos dos poetas da modernidade, na França e no Brasil, especificamente, Baudelaire e Pompéia. Repetimos que ambos criaram a prosa poética porque o narrador e/o eu poético em cada um deles faz uso do poder sugestivo da linguagem, por meio de analogias e correspondências, entre sons, cores, perfumes e símbolos, apresentando característica de brevidade, estilização da linguagem e de quase ausência de diegese.

Além disso, a temática, o uso da ironia e a construção que prioriza a criação de um efeito final e de uma epifania constituem aspectos comuns aos dois autores. Baudelaire manteve prática intertextual com Poe, devido a uma comunhão conceitual entre ambos, assim como entre 
Pompéia e Baudelaire. Para eles a poesia constituiu a meta de toda arte superior e o único meio de atingir o belo. Baudelaire e Pompéia evidenciam a noção de queda, a angústia do abismo.

Baudelaire esteve próximo do conceito de uma arte total em que a palavra, a cor e o som, graças a um difuso sistema de analogias, nos sugerem esse infinito sonho do espaço e profundidade em que consiste a suprema epifania da beleza. E esta influência pode ser vista nas canções de Pompéia. Baudelaire e Pompéia dialogaram com as dúvidas do século e descreram em dogmas e tradições. E, segundo Carpeaux (1963), Baudelaire não foi uma anima naturaliter christiana, mas sim uma anima naturaliter religiosa, capaz de criar uma religião particular que não estava ligada ao tradicional, mas mostrasse indícios de certo gnosticismo neopagão e uma espécie de maniqueísmo em que Lúcifer ocupa os altares da lírica baudelairiana, a exemplo das divindades inominadas e dos oxímoros de Pompéia.

Baudelaire, como produto de sua época, herdou do romantismo as contradições inconciliáveis, as tensões espirituais cujos pólos antitéticos nunca lograram atingir a síntese hegeliana . O absoluto e o infinito pelos quais o poeta ansiou ao longo de sua existência lhe foram impossibilitados pela sua sempre presente visão de queda, também compartilhada por Pompéia. Vejamos a exemplificação com o texto poético: As litanias de Satã.

“Ó tu, o anjo mais belo e sábio entre teus pares,

Deus que a sorte traiu e expulsou dos altares,

Tem piedade, ó Satã de minha atroz miséria!

Ó Príncipe do exílio, a quem fizeram mal

E que, vencido, sempre te ergues mais triunfal,

Tem piedade, ó Satã, de minha atroz miséria!

(BAUDELAIRE, 2002, p.74). 
No poema em prosa de Pompéia, - Solução XLIII, analisado neste capítulo, podemos perceber que a exemplo das idéias de Todorov, explicitadas anteriormente, não existe diferença entre o verso livre e a prosa poética, enquanto Jean Cohen afirma que a existência de silêncios ou espaços em branco no verso livre é a única característica que permite distinguir os versos livres da prosa poética. Acrescentamos, ainda, que na literatura brasileira prevalece a vertente mais artística ou cíclica do poema em prosa, com variações individuais de inflexão, tonalidade e atitude metafísica. As revoltas radicais de recusa das categorias temporais e lógicas, com predominância de uma estética da descontinuidade e da visão iluminada não surgem com freqüência. Retomemos a canção pompeiana, constante do corpus, para exemplificar.

Pára e retroceda, insensato!

Eu venho da grande viagem.

Desci ao fundo dos problemas; visitei, com o verme, as entranhas da terra; com o vendaval, os desertos; com os espectros, o coração da noite; com a estrela, o infinito; com os sonhos, o nebuloso passado! Deume luz o sol; deu-me vigor o penhasco; deu-me linguagem o trovão; deu-me energia o raio; deu-me asas o ciclone; deu-me arrojo o mar! Estudei, indaguei, ascultei, evoquei, observei. apostrofei, fui da apóstrofe à maldição; da maldição à blasfêmia! Aurúspice sacrílego, abri o ventre aos deuses! Sondei, sondei, sondei! Desafiei o gênio negro das metamorfoses; provoquei as vertigens do abismo!...

E o gênio negro respondeu:

“Nunca!”

E eu li no abismo:

“Nunca!”

(R. Pompéia, A Gazeta da Tarde, Rio de janeiro, 28 jan. 1886).

Os nomes abstratos e os temas metafísicos ligados à cosmologia que se destacam neste poema em prosa e, mais uma vez, há alianças incomuns na formação de sintagmas provocando estranhamento e contribuindo sonora e inovadoramente para maior expressividade retórica. Também, a seleção vocabular e a sintática servem como elemento rítmico no texto. Há inovação na ordem das palavras e na pontuação expressiva. 
As percepções são duais devido à utilização de antíteses constantes. As enumerações relativas à "grande viagem” do ser de enunciação neste texto de prosa poética, atuam como elementos de musicalidade no poema, os verbos têm função rítmica e musical. As frases curtas e a pontuação também contribuem para a expressividade retórica do poema, sugerindo ao mesmo tempo muito movimento, ações inúteis, para uma busca sem solução. E todos estes recursos estilísticos comprovam a forma inovadora de grande valor literário criada por Pompéia.

Com Baudelaire veio o retorno da poesia à sua essência e a ligação da arte literária à música. A poesia volta a ser, como na época dos gregos, uma manifestação divina, um êxtase da alma. Mas essa alma é humana, portanto filha da tensão e da contradição, afirma Ivan Junqueira (apud BAUDELAIRE, 2002, p. 81). Ele deu especial atenção à brevidade do texto, insistindo que tudo o que ultrapasse a duração da atenção que o ser humano pode prestar à forma poética não constitui um poema. Esse poeta, sobretudo, conferiu todo o sentimento metafísico que faltava à poesia musical e muitas vezes vazia de Poe. Foi ainda Baudelaire aquele que concretizou o sonho de libertar o verso de todos os elementos narrativos e didáticos que até então o poluíam, lançando na França, a exemplo de Pompéia no Brasil, os fundamentos da poesia moderna. “ Pascal em si tinha um abismo se movendo./ - Ai, tudo é abismo! - sonho, ação, desejo intenso, / Palavra! E sobre mim num calafrio, eu penso/ Sentir do Medo o vento às vezes se estendendo” (Op. Cit., p.85).

A temática da queda, compartilhada por Baudelaire e Pompéia remete ao abismo que está ligado ao caos do pensamento grego.Intimamente relacionada ao tema do abismo está a ânsia do infinito, também percebida em ambos escritores. E novamente a busca de infinito nos leva à queda, que em Baudelaire significa ao expurgo do éden terrestre. Todavia, o infinito em ambos apresenta-se finito, pois quase sempre leva à dissolução desesperançada. Há uma idéia de supranaturalismo percebida em Baudelaire e Pompéia. Ou seja, a morte constitui-se apenas de um acidente da queda que detém a carga semântica mais pesada. Essa influência parece vir dos mestres Poe e Swedenborg, para os quais a alma não corroída pela morte, leva uma existência fetal, até que o corpo seja totalmente destruído. Então a alma volta à sua autonomia, liberta. "Espesso, a fervilhar, qual um milhão de helmintos,/Em nosso crânio um povo de demônios cresce,/ E, ao respirarmos, aos pulmões a morte desce,/ Rio invisível, com lamentos indistintos” (op. cit., p. 88). 
Observamos que a distinção entre prosa e verso, no seu aspecto formal, não oferece nenhum problema. Os textos de Pompéia são identificados como prosa poética, em sua maioria, aparecendo alguns semelhantes aos poemas em prosa de Baudelaire. A fim de esclarecer as diferenças entre suas composições, observamos os traços recorrentes entre a forma dos pequenos poemas em prosa de Baudelaire e as canções de Pompéia.

\footnotetext{
À beira do caminho, um túmulo campestre. Os cães o revolveram;

a cruz cai; fora da cova, de envolta com a terra, uma caveira parece

intencionalmente voltada para o infinito. O osso recortado da face

afeta o riso áspero e impertinente, a ironia fixa de todas as caveiras.

No espaço e na terra, noite fechada, calma absoluta. Os astros olham

vagamente agitando os cílios de prata.

(Raul Pompéia) - Sic Transit
}

Baudelaire e Pompéia traziam o crítico dentro de si mesmos e anteciparam não apenas os temas da modernidade, mas todo o processo estético da poesia moderna. A seguir, um texto constante dos Pequenos poemas em prosa, de Baudelaire (2002, p. 283). 
O Bobo e Vênus

DIA ADMIRÁVEL! O vasto parque desfalece sob o olhar abrasante do Sol, como a juventude sob o império do Amor.

O êxtase universal das coisas não se manifesta por nenhum bulício; as próprias águas estão como adormecidas. Bem diversa das festas humanas - reina aqui uma orgia silenciosa.

Dir-se-ia que uma luz cada vez mais intensa faz brotar dos objetos cintilações cada vez mais vívidas, que as flores excitadas ardem no desejo de rivalizar com o azul do céu pela energia das suas cores, e que o calor, tornando visíveis os perfumes, os faz subir para o Sol como vapores.

Entretanto, nesse universal regozijo, divisei um ser aflito.

Aos pés de uma Vênus colossal, um desses bobos artificiais, um desses bufões voluntários encarregados de fazer rir os soberanos quando o Remorso ou o Tédio os atormenta, envolvido num traje vistoso e ridículo, toucado de chifres e de guizos, curvado sobre o pedestal, ergue os olhos cheios de lágrimas para a Deusa imorredoura

E os olhos dizem: - "Eu sou o último e o mais solitário dos homens, privado de amor e de amizade, muito inferior, neste ponto, ao mais imperfeito dos animais. No entanto, eu também fui feito para compreender e sentir a Beleza imortal! Ah, Deusa! Tende piedade da minha tristeza e da minha loucura!”

Mas a Vênus implacável olha para longe, vagamente, com os seus olhos de mármore.

(BAUDELAIRE, 2002, p. 283).

Vemos um texto bastante metafórico, prenhe de antíteses e símbolos. Há signos em letra maiúscula, conforme os textos anteriores, destacando as palavras com a carga semântica mais pesada. “Dia”, “Sol”, "Vênus”, “Bobo”, “Remorso”, “Tédio”, “Beleza”. O poema em prosa apresenta uma parte em modo narrativo, mas a poeticidade é bastante elevada pelo uso de inúmeros recursos estilísticos, sobressaindo o nível simbólico do texto e as inúmeras figuras. "Dir-se-ia que uma luz cada vez mais intensa faz brotar dos objetos cintilações cada vez mais vívidas, que as flores excitadas ardem no desejo de rivalizar com o azul do céu pela energia das suas cores, e que o calor, tornando visíveis os perfumes, os faz subir para o Sol como vapores”. 
Durante a pesquisa nos periódicos da época de Pompéia, encontramos um texto publicado no dia, 8 de janeiro de 1886, em a Gazeta da Tarde, na parte intitulada - Uma secção, com o título: Epiphania.

\section{UMA SECGÃO}

\section{EPPHANI}

Eram philosophos aquelles tres reis... Com razivo, dava-lhes o cèt para tria uua estrella. Harous do Oriente. Fiem valiam os salios do Occilente... Levaram ao hei tus reis a offirla sirnnifica-

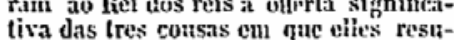
tiva das tres consas em que elles resi-
miatu a suprema realeza- outro, mingrhin, miasu a suprema realezi-outro, minrrlai.
incenso: realeza, perpetuidade, divinissrản.

(ine lles innortava que o lleus me nino tivesse par lerroo a mangredoura dus hois e o docel daytuella realeza nascente fusse, alli, u tecto esturratado du presene ?... Iram reis, e o Pequeno era presene ?... Iram reis, e o pequeno era
rei... Como rei deviam tralar-se... Se a rei.... Como rei deviam tralar-se... Se
Hlenino era mesmo rei, segrunto at verha das prophecias, o Reisinhto havia de entendel-os.

Ouro signifita o poter. Ouro \& o seeptro, na mite dos reis : uuro sào as chaves do Céu, na máo do pontifice de lioma. Comprar, subornar, steluzir, desmoralizar. situ de onro as syllabas desses rocalyylos. Conjugar a corruptato éat grammatica das tyraunias mansas. I sobernaia vive como os polvos-stlrando; os tentaculos tha solerania sioo de ouro. Fiste douraulo e esta irrediario de tentaculo faz o polvo parecer estrella. fei-sol quer dizer luiz XIV... Como se illmdern esse's tolos! Guanto mais berilhante e a realeza, tanto maior et a lrilhante e a realeza, tanto maior é a
energia pueumatica da stectio... E os povos auloram as realeziss deshimbrantes ! Tanto methor pare as calcetas co. rohldas!

Yinganom pensa en degolar uma divindade... A seiencia diss reis consiste $\mathrm{cm}$ saber fingir divintale... E. verdade que derolartam o hiji A pis, mas

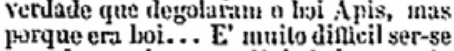
tomado a serio. como divindade, quando se é, alèm de dirindade, boi. Vejam que fint levou o bezerro de ouro, no tempo

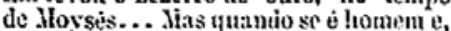
sendo homem, se linge ben ser divindate... o povo prostra-se.

Perfeitamente! Nada mas faeil do yue ser-se superior a um sujeito prostrato... Sor superior é a começo de ser deats... Os reis teven ter umito cuidarlo eu manter para si uma zrande eslatura de prestiorio... So houver al rotem ta illo, ent roda... l'or terra!... Quando min rei ć laxisho, enidato! em vez de pisar nu un corlezio, pise logro ent tres...
Issim, fira mais alt.... E :arada a thaior numera do kareto....

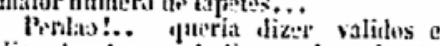
tisse taphtes... I lingua das nis, is

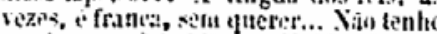

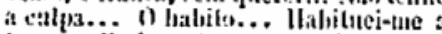

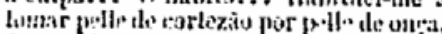
dirssas inofiensivas a curtiftas que or" estertien junto ilus sofas... .1las, pro seritinto...

Os reis devem apuener ser densis...

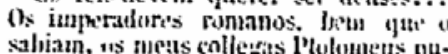
salian, "s meas collegits l'blomens punhian a theoria em praticat nos loms

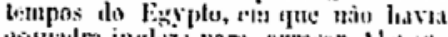

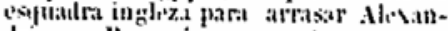

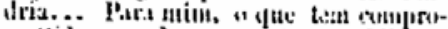

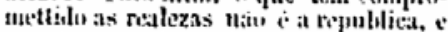

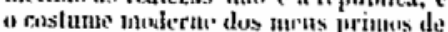

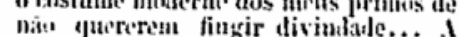

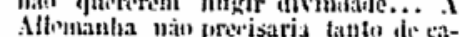

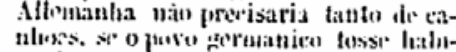

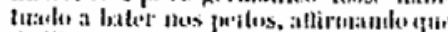

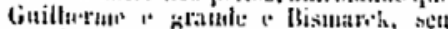

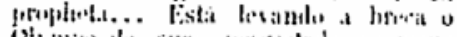
(b)

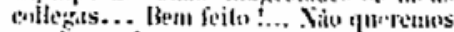
ser tirusins !...

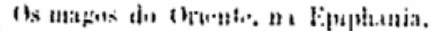

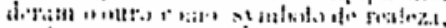

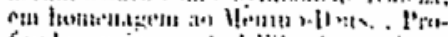

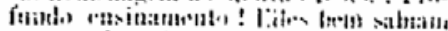

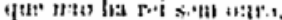

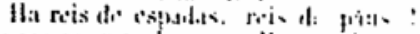

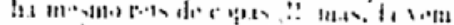

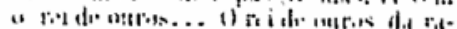

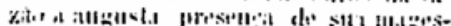

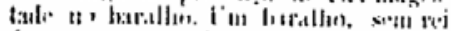

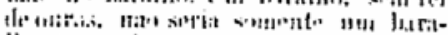

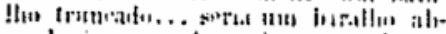

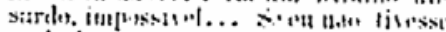

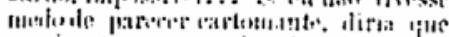

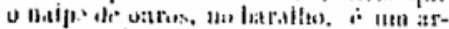

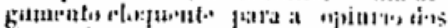

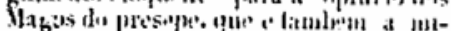
utit:

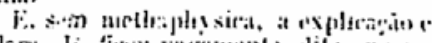

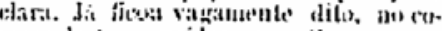

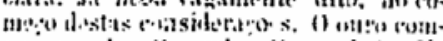

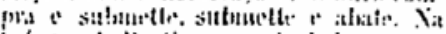

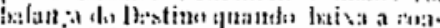

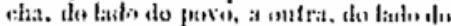

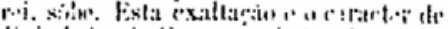

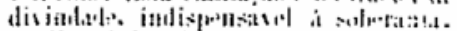

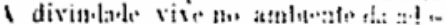

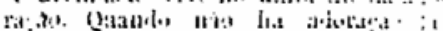

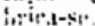

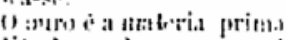

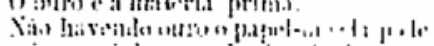

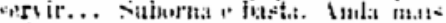

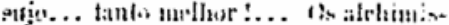
Las pacusavau a pedra phulusuptal...

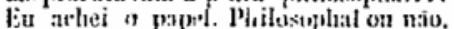

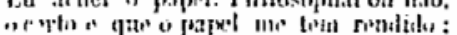

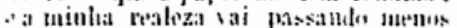

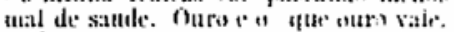

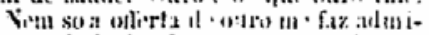

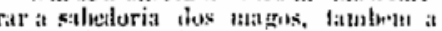

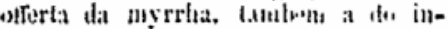
cinsto.

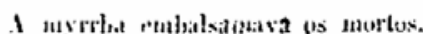

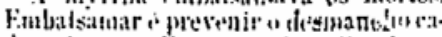

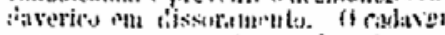

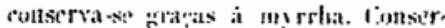

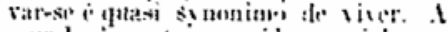
myrrha ins cuta uma vida es pertal para

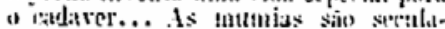

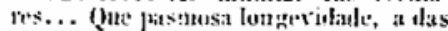

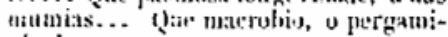
nlm !...

A merrlat fiter dizer que os reis devem achar mein de matar y proso e exjhurar a earetssa... So solle mustrar stmptomas de proxima discolat;io compleia... Mytrial no caso ! .. I" preciso

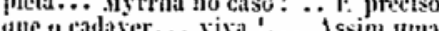
especie de Prometlinu difuneto, com tripas que nunca tuais se iltabum, para maier gattlio do alsutris.

0 ineenso... h : 0 inceruso! completa-se' o maravilhosu stumielismo dos magos.

Incenso quner lizer que ros relor do rei t:tlo dere estar de juellos, agitando "ati thursbulo. Fim torne do allar. onze millhes de siehristas... tudo de therryhetlo a lallantar... Oue esprectatuin para um rei ? O finmo do incenso creando un ar phantasias azues, sonhos vives de ploria, pronoranks interminos de vistwes

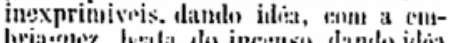

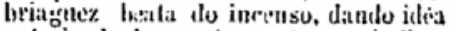
antecipala das venturas eternis ton Empyreo.

0 incenso e a ratificario do ourue da myrrith. A divinisatio do rei, o curo obtem-n'a, a myrrha, it perpelüia, o incenso, consagrai.

Subre at unultidtio, oscillam rormos pindentes de cadafalisos. Civismo, P'udor, Braviura. Honrs, Sentimento, é facil reconlecer-lhes os corpos suspensos... Iá ésti tudo esIranoulato!

(be importa !... Esses corpns ustillam ainda como thuribulos... Oine importa ! Sada ile fetor, caulaveres! Gerae perfitur, pulrefacyoss! Perfume ! perfune !....

Jncenso, para un!...

Amilrosia pard o denes :

Esto eseripto. sem assignatura, fol achalo nos jardins da oninta da the Vista, no dia de fieis.

Qiem o leria tray;ato? (onem o leria perdito :

li. P.

Figura 3: Epiphania.

Fonte: A Gazeta da Tarde, 8 jan. 1886. 
Apesar de o escritor não assumir sua autoria, devido ao estilo do texto, acreditamos que o autor é o próprio Pompéia que usou esse subterfúgio para não se identificar naquele momento, uma vez que o texto é uma crítica à corrupção daqueles que se encontram no poder, também porque ele publicou outros textos com pseudônimo ou assinando apenas as iniciais.

Pompéia termina a publicação dizendo ter encontrado aquele texto abandonado na Quinta da Boa Vista, no dia de Reis, questionando ao final do texto: “Quem o teria traçado? Quem o teria perdido?’. E acrescenta as suas iniciais após a pequena observação.

A caracterização do texto traz marcas do gênero inovador criado por Pompéia no Brasil. Sua leitura mostra traços do estilo de Pompéia, por exemplo, a preferência por símbolos, “ouro, mirra, incenso: realeza, perpetuidade, divinização”, o uso recorrente do comparativo “como”, “a soberania vive como os polvos - sugando; os tentáculos da soberania são de ouro”. Um outro fator é a erudição demonstrada no conhecimento dos clássicos, dando exemplos retirados da mitologia judaico-cristã, “os reis magos, Moisés”, da mitologia greco-romana, “Prometeu defunto, com tripas de nunca mais se acabam, para o gáudio do abutre”, ou de civilizações que a antecederam, como a egípcia: “os meus colegas Ptolomeus punham a teoria em prática, nos bons tempos do Egito, em que não havia esquadra inglesa para arrasar a Alexandria”; a ironia crítica “comprar, subornar, seduzir, desmoralizar, são de ouro as sílabas desses vocábulos”, a escolha de pontuação expressiva como recurso estilístico.

O texto aparece muito bem escrito e constitui um exemplo semelhante aos mencionados Pequenos poemas em prosa, de Baudelaire. Chamamos a atenção para a brevidade do texto, a estilização da linguagem e a poeticidade imbricada à prosa: “o fumo do incenso criando no ar fantasias azuis, sonhos vivos de glória, panoramas intérminos de visões inexprimíveis, dando idéia, com a embriaguez lenta do incenso, dando idéia antecipada das venturas eternas do Empíreo”.

O autor fala do presente ofertado ao “deus menino" pelos reis magos que ele chama de filósofos, exaltando a sabedoria do oriente: "Eram reis e como reis deviam tratar-se...”, justificando assim a escolha dos presentes, cujos signos simbólicos apresentam a carga semântica mais carregada: “ouro, mirra e incenso”.

O ouro simboliza o poder que está sempre ligado à corrupção: “conjugar a corrupção é a gramática das tiranias mansas”; “o ouro compra e submete, submete e abate”. “A soberania 
vive como os polvos - sugando: os tentáculos da soberania são de ouro”. “Ouro é o cetro, nas mãos dos reis; ouro são as chaves do Céu, na mão do pontífice de Roma”.

O segundo presente dos magos e elemento simbólico é a mirra, vejamos o seu significado: “a mirra embalsamava os mortos”, “o cadáver conserva-se graças à mirra”, “conservar-se é sinônimo e viver”, “que pasmosa longevidade, a das múmias... Que macróbio, o pergaminho!...” A mirra quer dizer que os reis devem achar meio de matar o povo e explorar a carcaça”.

"O incenso completa o simbolismo dos magos. Incenso quer dizer que em redor do rei tudo deve estar de joelhos, agitando um turíbulo. Em torno do altar, onze milhões de saeristas... Tudo de turíbulo a balançar... Que espetáculo para o rei!” Segundo o ser de enunciação, o incenso é a ratificação dos símbolos anteriores: “ouro e mirra”, porque o ouro possibilita a divinação do rei, a mirra, a perpetua e o incenso a consagra. E assim o texto finaliza: - "Sobre a multidão, oscilam os corpos pendentes de cadafalsos. Civismo, Pudor. Bravura. Honra. Sentimento. É fácil reconhecer-lhes os corpos suspensos... lá está tudo estrangulado! Que importa!... esses corpos oscilam como turíbulos... Que importa! Nada de fedor, cadáveres! Gerai perfume, putrefações! Perfume !...perfume!.../ Incenso , para um!... Ambrósia para o deus!”

\subsection{Análise dos textos do periódico}

A seguir passamos à análise dos poemas em prosa publicados em A Gazeta de Tarde, de 21 a 29 de janeiro de 1886.

\section{RUMOR E SILÊNCIO XXXV}

Ouvis, lá abaixo, o rumor da cidade? a grita dos homens, o estridor dos carros, o tropel dos ginetes, o fragor das indústrias?

Ouvis, de outra banda, as vozes da floresta, os pássaros saudando a tarde, o vento despertando as harpas eólicas das frondes? Ouvis esse clamor ingente das ondas que o horizonte nos envia?

Esta é a sinfonia, é a sinfonia da vida.

Diz-se então que o silêncio é a morte. 
Multiplicai esses rumores.

Agravai o tumulto industrial dos homens na paz, com as perturbações estrepitosas da guerra; reforçai as vozes da floresta e do mar; juntai-lhes a solene toada das catadupas, o pungente mugir dos oceanos lanceados pelo temporal, as explosões elétricas do raio, o medonho troar dos gelos, derrocados pelos primeiros sopros da primavera polar, o garganteio monstruoso dos vulcões inflamados; fazei rugir o coro das catástrofes humanas e os cataclismos geológicos.

Dizei, depois, onde mais intensa é a vida e mais assombrosa, se embaixo, se lá em cima, no zimbório diáfano desse firmamento que a noite vai conquistando agora, na savana imensa onde transitam os rebanhos das estrelas, onde os meteoros vivem, onde os cometas cruzam-se como espadas fantásticas de arcanjos em guerra - neste discreto abismo habitado pelos astros e pelo silêncio sagrado do infinito.

(A Gazeta da Tarde. Rio de Janeiro, 21 de janeiro de 1886).

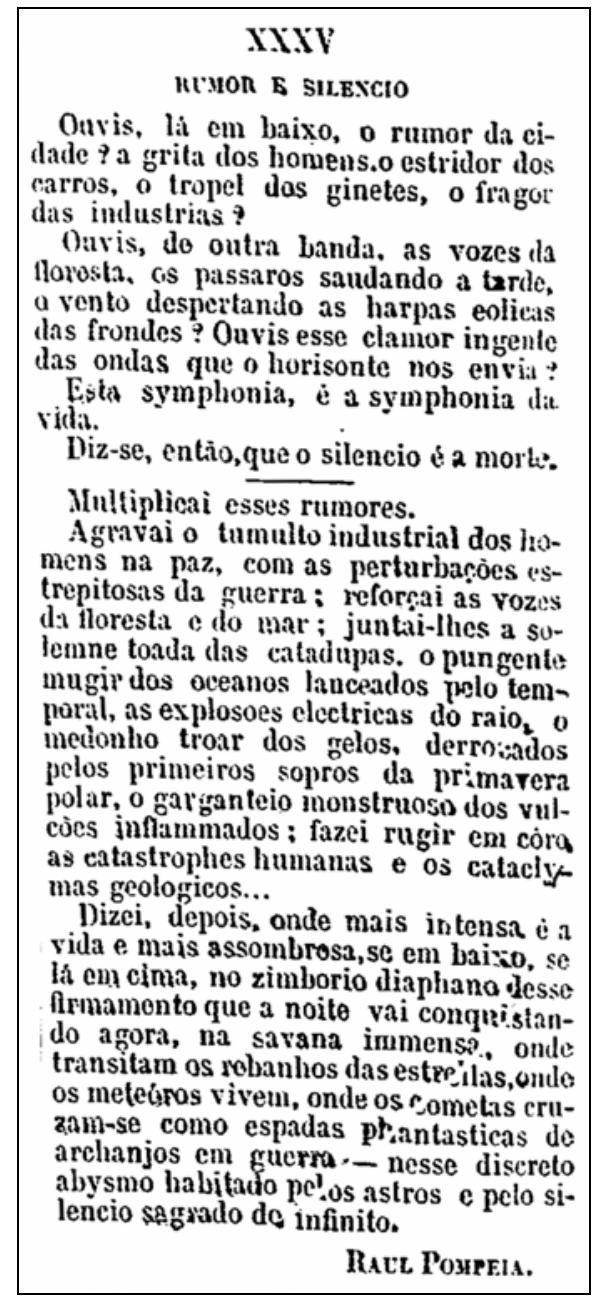

Figura 4: Rumor e Silêncio.

Fonte: A Gazeta da Tarde, 21 jan. 1886. 
Esse poema foi publicado em A Gazeta da Tarde, em 21 de janeiro de 1886, mas no mesmo número aparecem mais dois poemas do autor "SPES” e "Véritas", que não constam do corpus. Na impressão inicial, percebe-se uma série de perguntas dirigidas na segunda pessoal do plural, a um "vós” interlocutor, questionando os diversos rumores da cidade, da natureza, sucessivamente. A esse rumor o autor denomina como "sinfonia” e o define como "vida”, em contraposição ao silêncio que representa a morte. O oxímoro se apresenta a partir do título deste poema em prosa: Rumor e Silêncio. Na gênese do poema, ele utiliza expressões de rara beleza, "rebanho de estrelas”, “onde os cometas cruzam-se como espadas fantásticas de arcanjos em guerra”; “o medonho troar dos gelos, derrocados pelos primeiros sopros da primavera polar”. O ser anunciação pede que os rumores se multipliquem para preservar a "sinfonia da vida”, mas questiona onde a vida seria intensa, assombrosa, se "em cima “ ou “embaixo”, vida = rumor; morte = silêncio.

O elemento visual está presente em todo o texto, nas descrições que seguem a técnica cinematográfica de exposição seqüencial de imagens. Todavia, aqui também o auditivo tem lugar de destaque, pois a composição fala do "rumor e do silêncio”, signos relacionados contraditoriamente ao ouvido e com a carga semântica mais pesada dentro do texto.

A temática está ligada à inquietação de Pompéia, a busca de uma cosmologia em que o ser de enunciação utiliza elementos externos da realidade para mostrar uma outra realidade metafísica, interior.

A questão da focalização, ou seja, o pessimismo do autor em dialogismo com sua época, identifica a cosmovisão de Pompéia. No entanto, em “Rumor e Silêncio”, ele defende a possibilidade de vida "nesse discreto abismo habitado pelos astros e pelo silêncio sagrado do infinito”. Ou seja, aqui nesta versão jornalística ainda há certa crença espiritual ou metafísica que não aparece mais na versão burilada do livro.

A influência do jornalismo, nesta composição transdisciplinar, pode ser percebida no modelo piramidal (VIVALDI, 1979): introdução do texto, desenvolvimento e culminação final. As canções de Pompéia apresentam, ainda, certo nível narrativo, que é próprio do jornalismo e aqui coexiste com o nível poético. Neste exemplo percebe-se a originalidade do autor que compõe a introdução, que tem a função narrativa, com perguntas e respostas, usando pronomes e 
verbos na segunda pessoa do plural, recurso erudito e ao mesmo tempo dinâmico, devido à coexistência da função fático-referencial com a função poética, que neste texto, especificamente, tem uma dimensão persuasiva, ocupando um espaço híbrido não apenas relativo à forma da prosa poética, mas também transdisciplinar, relativo ao jornalismo e à literatura.

Em relação a essa linguagem jornalística, Pompéia, com seu talento literário e espírito de poeta não poderia ocupar na imprensa o papel de um periodista comum, que apenas se ativesse à informação, de acordo com as regras de sua época. Ele produziu textos mais originais, em exercício prático da forma, cujo aprimoramento ele perseguiu, burilando suas as Canções sem metro a cada publicação, em periódicos diversos e ao longo de sua vida. Neste texto, por exemplo, ele expõe o reflexo do mundo, traduzidos pela cor, pela luz e pelo ruído que o eu poético canta.

Pompéia manteve sua liberdade expressiva de escritor, com seu instinto periodístico, que exige condições especiais de sensibilidade junto à observação, sabendo ver e sabendo deixar ver, na construção de sua prosa poética com enfoque realista subjetivo e nuances impressionistas. Assim ele se manteve em segundo plano, mantendo certa impessoalidade, conforme o exige a linguagem jornalística, mas exercitando a criação de uma forma inovadora.

O autor tampouco se submeteu às limitações de temas, dando vazão à sua sensibilidade aguçada e ao sexto sentido profissional, expressando a sua cosmovisão e questionando infinitamente, por meio de sua linguagem. Seu objetivo foi o compartilhar das informações que ele detinha, por meio das técnicas de composição: as invariantes, o gênero inovador, sob a forma de prosa poética, a temática ligada à cosmogonia, o estilo, de acordo com o objetivo, a tentativa de expressão do mundo externo, como reflexo de seu mundo interior, em integração metafísica com a realidade.

Remetendo-nos aos traços gerais da teoria visual do impressionismo, proposta por Francastel (1974 apud RIBEIRO, 2001). Podemos perceber vários exemplos neste texto. Primeiramente a questão do espaço e a perspectiva da profundidade. Alonso (1977, p.112 apud RIBEIRO, 2001) diz que o texto verbal impressionista apresenta uma espécie de abandono da ordem lógica da frase e Ribeiro fez a aplicação e o reconhecimento dessas categorias da teoria visual do impressionismo em O Ateneu. Gandelman (1986, p.1910 apud 
RIBEIRO, 2001) acrescenta que o impressionismo constitui a hipóstase do olhar pousado sobre a tela, em nível microscópico e que somente o recuo desse olhar do receptor-leitor é capaz de recriar o olhar do artista que atribui sentido ao que percebe e que se encontrava velado entre as chamadas manchas de impressão. Estes recursos são percebidos também na leitura de as Canções sem metro que além de seu hibridismo no gênero e no modo, apresentam grande influência impressionista e técnicas de criação ligadas às artes visuais, porque o autor constrói um tipo de texto que implica leitura mais participativa para a sua compreensão. A experiência inovadora do poeta Pompéia trouxe grande contribuição à imprensa periódica, à semelhança de Poe, que o influenciou indiretamente por meio de Baudelaire.

Depois, há a questão da análise das situações e da atração pela animação. E, por último, a substituição do objetivo pelo subjetivo. "Dizei, depois, onde mais intensa é a vida e mais assombrosa, se embaixo, se lá em cima, no zimbório diáfano desse firmamento que a noite vai conquistando agora, na savana imensa onde transitam os rebanhos das estrelas, onde os meteoros vivem, onde os cometas cruzam-se como espadas fantásticas de arcanjos em guerra neste discreto abismo habitado pelos astros e pelo silêncio sagrado do infinito”.

Analisando as canções de Pompéia, podemos perceber a prioridade por certa limitação vocabular, cuja intenção é a ênfase nas antíteses “em cima” X “embaixo” e nos oxímoros constantes, “rumor e silêncio,” na construção dos sintagmas. A língua usada é a erudita e os símbolos estão sempre presentes: vida = rumor; morte = silêncio.

A repetição também faz parte do processo estilístico. Neste primeiro poema podemos mencionar a repetição de verbos, a preferência pela segunda pessoa do plural: ouvis; ouvis; multiplicai; agravai; reforçai; juntai-lhes; fazei; dizei. Ainda a repetição do advérbio: “onde mais intensa é a vida (...); “onde os cometas cruzam-se (...)”.

Percebe-se também eloqüência expressiva que provoca multiplicidade de planos e ressonâncias, por exemplo, o poema em prosa "Rumor e Silêncio” está dividido em três partes em seus sete pequenos parágrafos, o rumor citadino, o rumor da natureza e o "discreto abismo habitado pelos astros e pelo silêncio sagrado do infinito”. Nas duas primeiras partes o rumor se apresenta como símbolo da vida na matéria. No final do texto apresenta-se a vida ideal, vida 
iluminada, fatasticamente bela e silenciosamente intensa. A retórica apresentada é concisa, sóbria e de expressão concentrada.

Mas se tomar por ângulo a totalidade das imagens, percebemos que todas foram criadas a partir de diferentes imagens-suporte, ligadas ao rumor e ao silêncio, sobre as quais elementos picturais diversos foram acrescidos. O resultado da reunião destes elementos díspares é a criação de imagens oníricas, cuja leitura se faz no plano simbólico e, de acordo com o texto que as acompanha: “onde os meteoros vivem, onde os cometas cruzam-se como espadas fantásticas de arcanjos em guerra - neste discreto abismo habitado pelos astros e pelo silêncio sagrado do infinito".

Portanto, o diálogo com o texto torna-se fundamental, pois um confere sentido ao outro. A exemplo dos impressionistas, o uso das construções nominais está sempre presente, "as vozes da floresta e do mar” e o "rumor e silêncio".

Podemos, assim, observar a originalidade de Pompéia na construção de um novo gênero híbrido - a sua prosa poética. Sua visão completa da realidade parece estar regida pela contraposição de elementos antípodas, de valores antinômicos diversos, das idéias às sensações, do físico ao metafísico. Conseqüentemente, as suas representações artísticas tendem a se resolverem na expressão, por meio de estranhamento e oposições. Podem ser comprovadas as manifestações nas alianças verbais básicas do estilo, em que prevalece o oxímoro, em todas as suas formas, e o mundo do abstrato e do concreto se apresentam em constante polaridade. Esse transitar de seu espírito, que busca a síntese em movimento constante entre a realidade e a fantasia, do abstrato ao concreto, do lírico ao grotesco é uma característica do latino americano. Países em construção influenciam o artista. Além disso, as antítese ou oposições,”vida “e "morte”, “rumor” e "silêncio”, “guerra” e “paz”, “embaixo” e “em cima”, entre tantas outras, como vimos, emprestam maior relevo às idéias e à seleção vocabular do autor.

Como vimos, Pompéia utilizou em sua linguagem poética, as associações verbais, os temas oníricos, as metáforas e os jogos de palavras, como técnicas para captar e dar forma às imagens poéticas e interiores, desenvolvendo seus textos ligados ao jornalismo e à literatura. Chamo a atenção para o fato de o fato de que neste texto o visual se mescla ao auditivo 
hiperbólico, de acordo com o oxímoro: "rumor e silêncio”, nesta relação de contradição dialética em que um não existiria sem o outro.

Nas formas variantes, desenvolveu a sua poética ímpar, rica em símbolos e em imagens, com o ritmo peculiar à sua visão de mundo: “onde os cometas cruzam-se como espadas fantásticas de arcanjos em guerra - neste discreto abismo habitado pelos astros e pelo silêncio sagrado do infinito”.

O periodismo, segundo Vivaldi (1979) é algo muito mais que a técnica, as fórmulas, o trabalho e a habilidade. Constitui também arte e inspiração, assim como conhecimento de mundo e dos homens, por meio da psicologia e da filosofia aliadas a uma cultura sólida como no caso de Pompéia.

\section{VULCÃO MORTO XXXVIII}

À sombra do pico altíssimo, abre-se a cratera.

Rasgam-se precipícios sem fundo. Dominada pela vertigem, vai-se-nos a imaginação pelas fragas e perdese na sombra impenetrável, lá embaixo. Silêncio medonho.

Antes de tombar sobre o vulcão este silêncio pesado, quanta vez tremeram estas rochas, ao rugido da lava fervente!

Tentara o gigante em outro tempo, incendiar a amplidão; os séculos o puniram. Nada mais ficou dos grandes dias, além das escarpas calcinadas, velho esqueleto informe do colosso. Caíram para sempre os castelos de chama, que se erguiam sobre a cratera; extinguiram-se de vez as auroras infernais que o vulcão ateava nas trevas; pereceu a memória das erupções triunfais!

Tudo agora está morto. A caminho da lava escancaram-se os espaços como uma imensa boca, torcida na expressão de atroz agonia - brado supremo tolhido pela morte, apóstrofe muda e terrível, misteriosa blasfêmia arrojada, das entranhas da terra, à imensidade.

(A Gazeta da Tarde. Rio de janeiro, 22 de janeiro de 1886). 


\section{XXXYIII \\ velisio notro}

I' sombra to pieo altissimo, alseteso a criblera.

llis gratn-se proeipieios sem fumb. Do. minatla pela vertigem, vai-se-nos a imarinayjo pelass fragas e perde-se na somfra impenctravel, lá em baixo. Silencio medonlio.

Antes de tombar solure o vulioio esto silencio pesiulo, dquanta rez tremeram estis ruchas, ao rugialo da lava fervinle!

Tentára o grigrante em outro tempo. inerendiar a amplidio ; os seculos o puniran. Ninda niais ticou dos gramdes dias, alion das esearpas calcinalas, vetho esclueleto informe do colosso. lite hiram para sempre os eastellos de. chatuma, que se eryaiam subre a cratera ; pafinguiram-se de vez as auroras infernates que o voleto alliava nas trevas : perecen a memoria das crupgoes triumphates!

Tildu atgora esti mortu.

(1) caminho da lava escancara-se para us replayes romo uma immensal lroca, torcida nia expressào de atroz agonia brato suppreme tollitio nela morto, apostrophe mudis e ierrivel, mysteriosa blaspluemia arrojada, das entranhas da lerri, a immensidiade.

Figura 5: Vulcão Morto.

Fonte: A Gazeta da Tarde, 22 jan. 1886.

Como impressão inicial, a percepção da realidade que representa a presença ontológica e estética do poeta. O sintagma vulcão morto, e sua cratera “no pico altíssimo” x "precipícios sem fundo", "vertigem da imaginação", "silêncio agora”. Os oxímoros que se sucedem, primeiro no desvelar do outro, a natureza que define a forma estética de sua composição. “Silêncio agora” x “rugido do vulcão no passado”; “tentou incendiar a amplidão” x “punição silenciosa”; “as chamas infernais extintas” x “perecimento da memória esquecida”. 
A gênese da realidade que cerca o ser de enunciação está expressa na técnica de composição do poema. "Vulcão morto" fala da gênese do vulcão, morto na atualidade. O espírito que anima a realidade da vida é a constatação de que o ato criador só pode produzir palavras. "A chama extinta” x brado supremo tolhido pela morte”, “misteriosa blasfêmia arrojada, das entranhas da terra à imensidade”. O assentamento desta realidade ou a sua presentificação contra o fundo do tempo, assim como a constatação da nulidade ao final são expressos pelo eu poético. Tudo agora está morto é a síntese ou a resposta a seu questionar cosmogônico.

Observe-se a presença da visão como preponderante, seguindo a audição e o olfato. Pompéia também inova ao estabelecer relações associativas entre substantivo e adjetivo, "brado supremo tolhido pela morte, apóstrofe muda e terrível, misteriosa blasfêmia arrojada, das entranhas da terra, à imensidade”, com a intenção de lhes ampliar o potencial de elos expressivos de significado, de funções gramaticais e de mobilidade da frase.

O autor busca afirmar no adjetivo a impressão dominante do fenômeno que vai envolver todos os outros elementos da frase. “(...) vai-se-nos a imaginação pelas fragas e perde-se na sombra impenetrável, lá embaixo. Silêncio medonho.(...) Caíram para sempre os castelos de chama, que se erguiam sobre a cratera; extinguiram-se de vez as auroras infernais que o vulcão ateava nas trevas; pereceu a memória das erupções triunfais! Tudo agora está morto.” Assim, ele consegue maior concentração imagística , que se torna deveras expressiva.

E, segundo Todorov (1967), a metáfora em sentido lato é a característica fundamental da linguagem poética.’Tudo agora está morto. A caminho da lava escancaram-se os espaços como uma imensa boca, torcida na expressão de atroz agonia - brado supremo tolhido pela morte, apóstrofe muda e terrível, misteriosa blasfêmia arrojada, das entranhas da terra, à imensidade”.

Pode-se observar, ainda, a seleção vocabular e sintática como elemento rítmico da frase: “silêncio medonho”, as frases são curtas, assim como o poema:”tudo agora está morto; à sombra do pico altíssimo, abre-se a cratera”, “os séculos o puniram”, mas o conjunto forma um todo orgânico, planejado cuidadosamente.

Mais uma vez, pode-se perceber o nível narrativo: “à sombra do pico altíssimo, abre-se a cratera”, no início do texto, nesta composição piramidal contaminada pela influência do jornalismo. A canção em prosa poética está dividida em três partes, especificamente: a 
introdução em nível mais narrativo, o desenvolvimento intermediário que aparece magistralmente no tempo verbal mais que perfeito, provocando efeito de distanciamento no tempo, e o final concreto: “ tudo agora está morto”, mais uma vez mostrando a influência do jornalismo nesta divisão cronológica piramidal.

No entanto, após esta constatação definitiva, a poeticidade que finaliza, mostrando o nível de cruzamento entre duas linguagens: a jornalística e a literária.”A caminho da lava escancaram-se os espaços como uma imensa boca, torcida na expressão de atroz agonia brado supremo tolhido pela morte, apóstrofe muda e terrível, misteriosa blasfêmia arrojada, das entranhas da terra, à imensidade”.

O elemento visual se presentifica em todo o texto, nas descrições sobre o vulcão morto. A cor que prevalece é o escuro do fundo do precipício ou da sombra, de acordo com os castelos de chamas que foram extintos. "Caíram para sempre os castelos de chama, que se erguiam sobre a cratera; extinguiram-se de vez as auroras infernais que o vulcão ateava nas trevas; pereceu a memória das erupções triunfais!” Todavia, aqui também o auditivo teve lugar no passado. “Antes de tombar sobre o vulcão este silêncio pesado, quanta vez tremeram estas rochas, ao rugido da lava fervente!” esse passado aparece distanciado pelo uso do tempo verbal mais que perfeito: “tentara o gigante em outro tempo incendiar a amplidão; os séculos o puniram.”

A temática continua ligada à inquietação do ser de enunciação em Pompéia: a busca de uma cosmologia em que o eu poético se utiliza de elementos externos da realidade para mostrar uma outra realidade metafísica, interior. “Tudo agora está morto. A caminho da lava escancaram-se os espaços como uma imensa boca, torcida na expressão de atroz agonia brado supremo tolhido pela morte, apóstrofe muda e terrível, misteriosa blasfêmia arrojada, das entranhas da terra, à imensidade”. Aqui também se percebe, na questão da focalização, o pessimismo do autor em dialogismo com sua época, identificando a cosmovisão de Pompéia.

Voltando aos traços gerais da teoria do impressionismo, de Francastel (1974), estudados por Ribeiro (2001), percebemos neste texto a questão do jogo de luz e sombra, na descrição em gradação decrescente do vulcão ativo em relação ao vulcão morto, “caíram para sempre os castelos de chama, que se erguiam sobre a cratera; extinguiram-se de vez as auroras infernais que o vulcão ateava nas trevas; pereceu a memória das erupções triunfais!”. 
Percebe-se também uma mudança de perspectiva a partir do eu poético, que transita e faz transitar o olhar do leitor do passado do vulcão ativo para o presente do vulcão morto. O olhar do leitor receptor caminha desde as “entranhas da terra” até “à imensidade”. As partes iniciais do texto apresentam-se distanciadas, ao longe, “caíram para sempre os castelos de chama”, o fogo é símbolo da destruição. Na última parte “tudo está morto”, passivo, sobrevivo.

\section{OS CONTINENTES XXXIX}

\section{“Atlântida! Atlântida!}

Onde estão agora as florestas, as torrentes caudais, as cidades, os reinos? Onde os homens, os rebanhos, as feras? Monumentos, grandeza, poderio, exércitos, ciências, e as gloriosas artes?...onde jaz sepultado o gênio humano fertilizador das regiões desaparecidas?

Que é feito das próprias ruínas? Como foram consumidos os restos venerandos da arquitetura - fustes decepados, capitéis caídos? E os túmulos? e as ossadas dispersas, que são o vestígios da passagem das gerações pela estrada interminável dos séculos e da morte?... E as montanhas, que pareciam eternas, na audaciosa majestade da pedra, convivendo com a águia e com o raio, como Júpiter, Deus?!...

Os monstros sabem talvez - os monstros do mar profundo, que nadam em silêncio, demorando no olhar espantado sobre o montão de escombros perdidos na fosforescente noite do abismo; mas guardam tenazmente o formidável segredo do seu espanto.

A face do oceano é discreta como um mármore sem inscrições.

Debalde o sol agride com os dardos irreverentes da luz, a superfície amplíssima da campa. Os dardos quebram-se, repelidos pela couraça impenetrável do mistério.

Debalde a tormenta rasga e dilacera, chacal sacrílego, com as furiosas garras, a espessura esmagadora que se acama sobre o continente submergido...

Terror perene e indefinível dos continentes vivos, a interrogação permanece”.

(A Gazeta da Tarde. Rio de Janeiro, 22 de janeiro de 1886). 


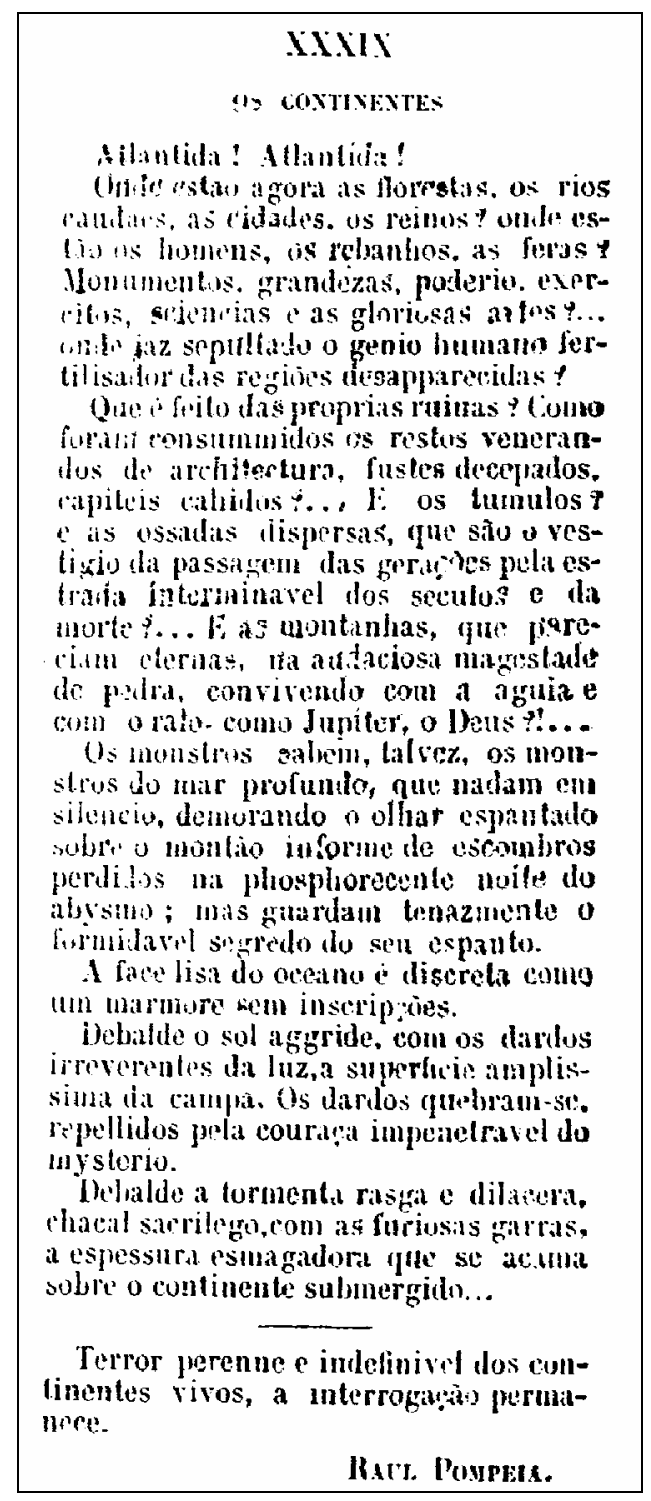

Figura 6: Os Continentes.

Fonte: A Gazeta da Tarde,.22 jan. 1886.

O eu poético questiona todas as formas que desapareceram com Atlântida e faz uso de frases riquíssimas, devido às combinações sintagmáticas de relevante poeticidade. “Os monstros do mar profundo que nadam em silêncio, demorando o olhar espantado sobre o montão informe de escombros perdidos na fosforescente noite do abismo; mas guardam tenazmente o formidável segredo do espanto. A face lisa do oceano é discreta como um mármore sem inscrições”. Também a seqüência de figuras que formam verdadeiro tapete metafórico, composição altamente sensível de símbolos que se sucedem e se entrelaçam. 
Nesse texto, “Os continentes”, o que fortalece o pessimismo da sua visão, isto é, todo o processo de criação é uma constante contradição, um oxímoro, cuja solução constitui-se de um desejo de criação, batalha travada contra a nulidade infinita. Isto aparece em sua linguagem poética que sugere a impotência das revoltas e das revoluções da natureza, frente à opressão da pedra, metonímia dos continentes e dos litorais rochosos que restringem os seus limites.

Entretanto, o poema "Os continentes" assim como os dois últimos que encerram nosso corpus das Canções sem metro contradizem o pessimismo sem solução do eu poético em outras composições. Ao término, a constatação do poeta: “Terror perene nos continentes, a interrogação permanece”, sobre o continente submerso de Atlântida.

Observe-se a inovação na ordem das palavras e na pontuação expressiva, carregada de sinais, interrogações, exclamações, reticências, vírgulas, ponto, travessão, que têm o efeito de pausa superlativa; o emprego dos tempos verbais, frases interrogativas e exclamativas com função de interjeição, criando neologismos de significado, o ritmo binário, as antíteses, o paralelismo e a simetria neste poema. “Onde estão agora as florestas, as torrentes caudais, as cidades, os reinos? “Onde os homens, os rebanhos, as feras?”. As elipses ou a omissão de verbo provocam estranhamento, trazendo maior poeticidade expressiva:"Monumentos, grandeza, poderio, exércitos, ciências, e as gloriosas artes?... onde jaz sepultado o gênio humano fertilizador das regiões desaparecidas?”

O uso freqüente da estrutura enumerativa, os cruzamentos entre as duas linguagens, jornalística e literária, relato breve e poético ao mesmo tempo, as combinações rítmicas, a prosa poética pela harmonia imitativa, pela aliteração, pelo uso da repetição como agente lírico, a similicadência, assim como a combinação dos ritmos métricos e acentuais, junto a todos os outros recursos comprovam o talento excepcional de Pompéia na criação dessa forma inovadora.Vejamos o exemplo abaixo:

“Que é feito das próprias ruínas? Como foram consumidos os restos venerandos da arquitetura - fustes decepados, capitéis caídos? E os túmulos? e as ossadas dispersas, que são o vestígios da passagem das gerações pela estrada interminável dos séculos e da morte?... E as montanhas, que pareciam eternas, na audaciosa majestade da pedra, convivendo com a águia e com o raio, como Júpiter, Deus?!...”. 
O autor, ainda, busca afirmar, no adjetivo, a impressão dominante do fenômeno do desaparecimento de Atlântida, o que vai envolver todos os outros elementos da frase. E as montanhas, “que pareciam eternas, na audaciosa majestade da pedra”, Assim, ele consegue maior concentração imagística, maior expressividade. Tal como escritores românticos que pintavam a natureza subjetivamente, dando-lhe atributos além do real concreto, também Pompéia a utiliza para criar e acentuar um determinado estado da alma ou impressão subjetiva.

\footnotetext{
“E as montanhas, que pareciam eternas, na audaciosa majestade da pedra, convivendo com a águia e com o raio, como Júpiter, Deus?!...Os monstros sabem talvez - os monstros do mar profundo, que nadam em silêncio, demorando no olhar espantado sobre o montão de escombros perdidos na fosforescente noite do abismo; mas guardam tenazmente o formidável segredo do seu espanto”.
}

Os nomes abstratos, o lirismo ao longo do texto e a riqueza de metáforas, os temas metafísicos ligados à cosmologia, as alianças incomuns na formação de sintagmas provocando estranhamento e contribuindo sonora e inovadoramente para maior expressividade retórica. A seleção vocabular e a sintática também atuam como elemento rítmico das frases, além da comparação, freqüente no discurso poético de Pompéia. " $E$ as montanhas, que pareciam eternas, na audaciosa majestade da pedra, convivendo com a águia e com o raio, como Júpiter, Deus?!...”

A influência jornalística pode ser entrevista no nível narrativo, que permeia toda a canção, entrelaçado com o nível poético. Esse fio narrativo apresenta dimensão lírica contribuindo para a elevada poeticidade obtida pelo estilo ímpar do poeta. "Os monstros sabem talvez, os monstros do mar profundo, que nadam em silêncio, demorando o olhar espantado sobre o montão de escombros perdidos na fosforescente noite do abismo; mas guardam tenazmente o formidável segredo do seu espanto”.

A estrutura cronológica piramidal, de acordo com Vivaldi (1979) apresenta-se, assim, construída: a introdução ou início atrativo do texto que traz exclamações iniciais e interrogações oratórias, “Atlântida! Atlântida! / Onde estão agora as florestas, as torrentes caudais, as cidades, os reinos? Onde os homens, os rebanhos, as feras? Monumentos, grandeza, poderio, exércitos, ciências, e as gloriosas artes?...onde jaz sepultado o gênio humano fertilizador das regiões 
desaparecidas?”; a segunda parte da pirâmide é constituída de estrutura simbólica em que as imagens e os símbolos mergulham uns no outros e é difícil separá-los, assim como é difícil perceber o que é linguagem jornalística e literária, em razão de sua imbricação e da abundância dos recursos estilísticos usados por Pompéia. Percebemos que os símbolos surpreendem e provocam a atenção do leitor. A parte derradeira da técnica piramidal é o final concreto: "terror perene e indefinível dos continentes vivos, a interrogação permanece”.

Os símbolos são inúmeros: “túmulos”, “ossadas”, para elementos desaparecidos, “montanhas”, "pedra“, para elementos considerados de longa duração, concretos, passíveis de convivência com os seres superiores, aqui simbolizados pela águia e pelo deus júpiter; “tormenta”, “chacal sacrílego”, força d’água responsável pela submersão do continente desaparecido, entre tantos outros.

Como vimos, o texto também está dividido em três partes. A primeira tem como tópico frasal um vocativo dirigido ao continente de Atlântida, seguido de dois parágrafos de interrogações sobre a mesma terra desaparecida. Nesta primeira parte o recurso de pontuação, elipse, frases nominais, substantivo e adjetivos trabalhos estilisticamente, seleção vocabular preciosa, muitas perguntas provocam efeito bastante literário imbricado à introdução que apresenta também a interferência da linguagem jornalística que chama a atenção do leitor pela série de questionamentos.

A segunda parte é constituída frases afirmativas, dando seqüência ao fio narrativo de relevante lirismo.A repetição do signo “monstros” , monstros do mar profundo, intercalado pelo advérbio “talvez”, tem um efeito deveras poético. Também a repetição do advérbio “debalde”, em dois parágrafos consecutivos, assim como a seleção de verbos com semas ligados à destruição em ordem crescente: “agride”, “quebra”, “rasga”, “dilacera” demonstra o cuidado do autor na seleção vocabular para a construção de um efeito forte, completado pelos sintagmas: “chacal sacrílego”, “furiosas garras”, “espessura esmagadora”. Depois a calma com o uso do verbo: “acama” para falar do continente submerso.

A última parte é curta e constituída de frases nominais: “terror perene e indefinível dos continentes vivos, a interrogação permanece”. 


\section{OS DEUSES XV}

D’onde vens, divino sol? Que ideal te propele na infinita jornada?

Vê! Teus raios penetraram a natureza como uma vida nova; ao teu olhar, o universo ressurge e rejuvenesce. Ouve! Há risos sob a relva e canções no arvoredo!

É teu o ouro das asas do inseto; o verde dos bosques é teu; é teu o azul dos espaços. Todas estas pétalas que resplendem iriadas, recamando os prados, todas elas foram coloridas pelo minucioso pincel da tua luz.

Que estranha Divindade és tu, glorioso sol, que me deslumbras?

Sem a tua presença toda esta paisagem jazera morta. Toda esta alegria que eu sinto emana de teu fulgor, astro onipotente, criador do dia e das cores...

Ah! eu adoro o sol que é a força.

Vem do mistério como os deuses, e vai para o mistério...

Por que buscar, mais alto, outra divindade além?!

Entretanto, ouviu-se o sino da aldeia e o entusiasmo do sol (era o cura!) cortou arrependido a torrente blasfema dos seus transportes.

(A Gazeta da Tarde. Rio de Janeiro, 25 de janeiro de 1886). 


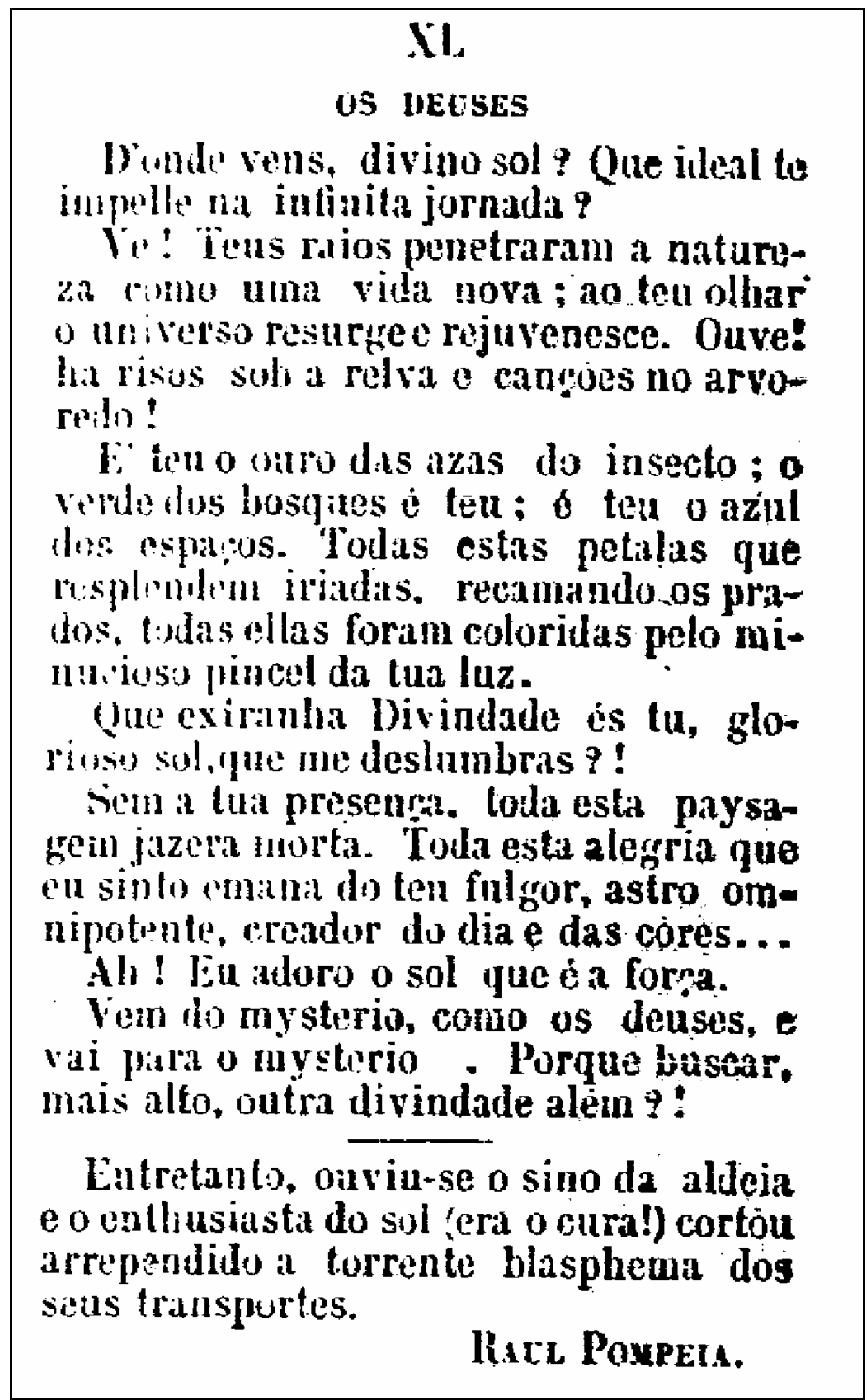

Figura 7: O Deuses.

Fonte: A Gazeta da Tarde, 25 jan. 1886.

Este poema em prosa constitui-se de uma ode ao sol, em que o ser-de-enunciação tece elogios, reverencia e declara seu amor, ao astro rei, ao qual se dirige, como: "astro onipotente”, “criador do dia e das cores...”, “sem a tua presença, toda esta paisagem jazera morta”. O poema apresenta em sua técnica de composição características semelhantes aos dos cantos entoados à natureza, sempre dirigidos à natureza-mãe. “Ah! Eu adoro o sol que é a força. Vem do mistério, como os deuses, e vai para o mistério...Por que buscar, mais alto, outra divindade além?!” 
Ao final do poema, a exaltação do transporte poético é interrompida pelo badalar do sino da igreja. "Entretanto, ouviu-se o sino da aldeia e o entusiasmo do sol (era o cura!) cortou arrependido a torrente blasfema dos seus transportes”.

Ao lirismo da canção expresso por meio de imagens nucleares, junta-se o caráter cíclico de suas canções em prosa, nas quais, quase sempre, são retomados os motivos iniciais como chave final. “D’onde vens, divino sol?” (...) Ah! eu adoro o sol que é a força.(...) Por que buscar, mais alto, outra divindade além?!

Sua forma metafórica também oferece ao leitor as possibilidades de movimentação subjetiva, quando se repartem as vozes da discussão. Percebe-se ainda uma tonalidade moralizante, meio profética, concretizada sob a forma de aforismos, o que contribui para adicionar-lhes um tom de intemporalidade ou tempo mítico, às vezes marcado pela ironia originária de um pensamento filosófico. “D’onde vens, divino sol? Que ideal te propele na infinita jornada?”.

Pode-se observar que a seleção vocabular e a sintática atuam como elemento rítmico das frases. Os verbos apresentam função rítmica e musical. "Que estranha Divindade, és tu, glorioso sol, que me deslumbras? Sem a tua presença toda esta paisagem jazera morta. Toda esta alegria que eu sinto emana de teu fulgor, astro onipotente, criador do dia e das cores...” O eu poético em Pompéia faz alusão ao sol, como símbolo do princípio de tudo e sabemos que esse astro era reverenciado como a divindade dos antigos egípcios. O recurso da repetição de determinadas palavras, como elementos de musicalidade no poema também integram esta composição. "É teu o ouro das asas do inseto; o verde dos bosques é teu; é teu o azul dos espaços.”

Há inovação na ordem das palavras e na pontuação expressiva. "Entretanto, ouviu-se o sino da aldeia e o entusiasmo do sol (era o cura!) cortou arrependido a torrente blasfema dos seus transportes.”

Ao mesmo tempo, podem ser observados elementos científicos, materiais, em contraposição a elementos idealizados, ou seja, Ah! eu adoro o sol que é a força. / Vem do mistério como os deuses, e vai para o mistério... / Por que buscar, mais alto, outra divindade além?!” 
O neologismo de significado aparece assim: "Entretanto, ouviu-se o sino da aldeia e o entusiasmo do sol (era o cura!) cortou arrependido a torrente blasfema dos seus transportes” .

Percebem-se alianças incomuns na formação de sintagmas provocando estranhamento e contribuindo de maneira sonora e inovadora para maior expressividade retórica do poema. Deve-se observar que os poemas em prosa de Pompéia não mencionam Deus, e rendem culto apenas à natureza, especificamente, ao sol, conforme visto nesta Canção sem metro - “Os deuses,” constante do corpus da pesquisa. Esse fato sugere uma visão do universo marcada por uma espécie de panteísmo ateu. Essa hipótese encontra respaldo em vários textos e alegorias, mas entre eles se destaca este poema, cuja epígrafe extraída de El Diablo mundo, de José de Esprocenda (apud POMPÉIA, 1982, p. 95) remete-nos ao tema das crenças religiosas consideradas como ilusões: "Las creencias que abandonas, / Los templos, las religiones / Que pasaron, y que luego / Por mentira reconoces, / Son, quizá, menos mentira / Que las que ahora te forges?". No lugar de Deus, o eu poemático acredita no sol. Repetimos o exemplo, para maior clareza.

[...]"no astro onipotente, criador dos dias e das cores": Que estranha potestade és tu, glorioso sol que me deslumbras?! Sem a tua presença toda esta paisagem jazera morta. Toda esta alegria me acorda o sangue e um vivo eflúvio de fulgor, astro onipotente, criador das cores e dos dias! Ah! Eu adoro o sol que é a força. Vem do mistério como os deuses e, como os deuses vem, como os deuses vai para o mistério. Por que buscar mais alto a Divindade?!

Na seleção vocabular percebem-se signos que carregam conotações relacionadas à luz, à cor e á vida, predominando o elemento visual no poema. “É teu o ouro das asas do inseto; o verde dos bosques é teu; é teu o azul dos espaços. Todas estas pétalas que resplendem iriadas, recamando os prados, todas elas foram coloridas pelo minucioso pincel da tua luz”.Todavia, o elemento auditivo também se faz presente, aliado à presença da linguagem figurada que dá maior efeito lírico ao texto. “Ouve! Há risos sob a relva e canções no arvoredo!” Baudelaire esteve próximo do conceito de uma arte total em que a palavra, a cor e o som, graças a um difuso sistema de analogias, nos sugerem esse infinito sonho do espaço e profundidade em que 
consiste a suprema epifania da beleza. E aqui neste texto de Pompéia percebe-se essa influência. Devemos, ainda, atentar para a seleção das cores que têm a cor de nossa nacionalidade, “ouro”, “verde” e “azul”.

O texto também está dividido em três partes, seguindo a divisão piramidal. A primeira, introdutória aparece na forma de interpelação ao sol sobre sua origem. No desenvolvimento, a declaração do amor do eu poético àquela divindade responsável pela cor e pela vida. No final, uma espécie de epílogo, na terceira pessoa, uma ruptura na canção em que o questionamento e a ode ao astro rei proferida pelo ser de enunciação é interrompida pelo toque do sino na a igreja. "Entretanto, ouviu-se o sino da aldeia e o entusiasmo do sol (era o cura!) cortou arrependido a torrente blasfema dos seus transportes”.

Percebe-se nas canções de Pompéia várias características próprias da linguagem jornalística, apesar do alto teor de poeticidade.Exemplificando, temos nesta última citação muita originalidade no enfoque do autor que mostra seu ponto de vista. Além disso, percebemse qualidades estilísticas como a densidade da temática, a exatidão dos termos, sua precisão, a sensatez do eu poético, a naturalidade e o ritmo de cada canção, a correção da linguagem e sua propriedade. Sobretudo a claridade das idéias e a correspondente transparência expositiva, além da brevidade, características de todas as canções de Pompéia.

\section{SIC TRANSIT XLI}

À beira do caminho, um túmulo campestre. Os cães o revolveram; a cruz caiu; fora da cova, de envolta com a terra, uma caveira parece intencionalmente voltada para o infinito. O osso recortado da face afeta o riso áspero e impertinente, a ironia fixa de todas as caveiras. No espaço e na terra, noite fechada, calma absoluta; os astros olham vagamente agitando os cílios de prata. . Dir-se-ia sentir o monólogo meditativo dos seres através da sombra.

\section{O TÚMULO}

Das passadas arrogâncias, nada encontrei neste invólucro do osso. Pura lama, o cérebro estulto que concebeu dividir em tribos a inumerável vegetação das várzeas e das montanhas, dar nome a cada uma das rochas subterrâneas, inquirir o problema permanente das origens!...Perderam-se os efêmeros atrevimentos.

E a vegetação do solo ubérrimo cresce como sempre, desordenada e festiva; o granito; e as rochas imortais amparam o zimbório das cavernas com o possante dorso, indiferente à vaidade das teorias. 


\section{UMA ESTRELA}

Moravam naquele crânio as teorias; havia nele idéias, como há constelações no éter; cada pensamento era um meteoro, relampeando naquele céu.

O cérebro ditava as leis; impunha-nos a geometria; marcava- nos o futuro, explicava-nos o passado!...

Vão-se as teorias, apagam-se as constelações das idéias, parecem as fórmulas com o cérebro e nós, eternas como divindades - vivemos!

(A Gazeta da Tarde. Rio de Janeiro, 27 de janeiro de 1886).

\begin{tabular}{|c|}
\hline 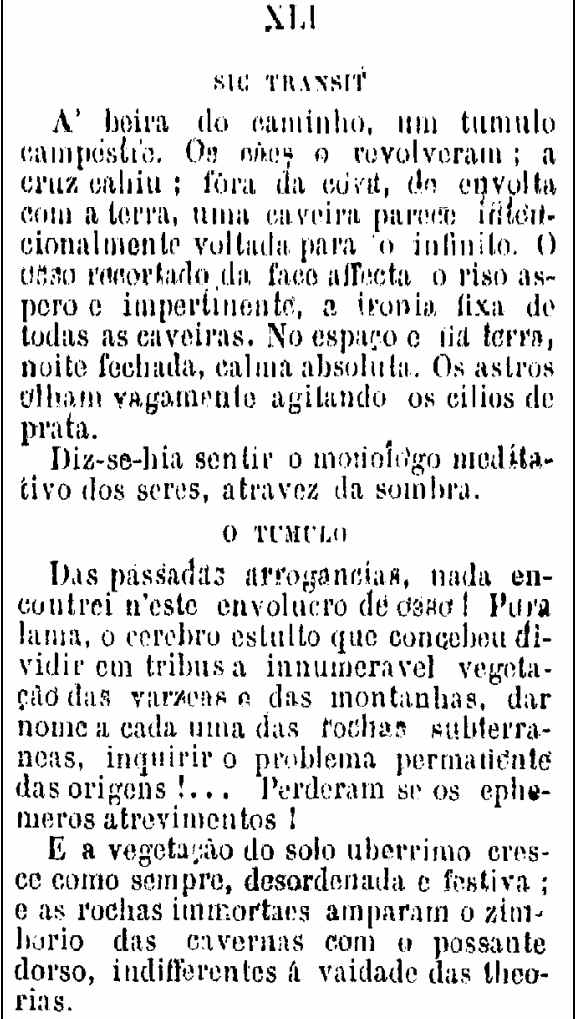 \\
\hline
\end{tabular}

Figura 8: Sic Transit.

Fonte: A Gazeta da Tarde, 27 jan. 1886. 
Este poema em prosa remete-nos à efemeridade das coisas e se divide em pequena introdução, a percepção da realidade (digressões poéticas à beira de um túmulo campestre), realidade que o poeta descreve, fazendo muito uso de imagens visuais como sempre, e duas outras partes que trazem como palavra chave, “o túmulo” e "as estrelas” especificamente. A efemeridade a partir do título está ligada a elementos e a construções que falam da fugacidade da vida e da inutilidade de sentimentos como: a vaidade, a arrogância, os atrevimentos. A última parte faz menção à capacidade mental, ao exercício do intelecto, às marcas do tempo tridimensional: passado e o futuro, que foi presente um dia. Isto é sugerido de maneira magistral. Tudo passa = sic transit. O que permanece são as estrelas eternas como divindades. Percebe-se, aí, um vislumbre de esperança talvez tão inatingível como as estrelas.

Neste poema em prosa, podem ser observados elementos científicos, materiais em contraposição a elementos idealizados, como: “túmulo” e “estrela”.Em relação á linguagem jornalística o primeiro componente é constituído pela brevidade do texto que também está dividido como os anteriores em três partes e apresentam clareza na expressão das idéias, apesar de sua literariedade, ao lirismo cheio de imagens e símbolos que se sucedem e se encadeiam. Percebemos, ainda, em vários textos de Pompéia que ele cria imagens e símbolos de caráter horizontal ou vertical. Aqui o concreto é horizontal "túmulos” e o subjetivo ou metafísico é vertical “estrelas”.

Optamos pela terminologia relativa à lírica: ser de enunciação, eu poético ou poemático, apesar de constatar o nível narrativo em todas as canções, devido ao seu caráter de gênero híbrido. A escolha se explica pelo elevado lirismo na escritura artística de Pompéia.

Apresentando características do estilo impressionista, Pompéia faz uso das construções nominais que estão sempre presentes. “À beira do caminho, um túmulo campestre. Os cães o revolveram; a cruz caiu; fora da cova, de envolta com a terra, uma caveira parece intencionalmente voltada para o infinito”. É difícil falar em tempo cronológico nas canções de Pompéia que devido à busca metafísica do ser de enunciação imbrica-se ao tempo mítico.

Os neologismos de significado também aparecem contribuindo para a beleza ímpar desta composição. "Moravam naquele crânio as teorias; havia nele idéias, como há constelações no éter; cada pensamento era um meteoro, relampeando naquele céu”. 
Os nomes abstratos, temas metafísicos ligados à cosmologia, (...) inquirir o problema permanente das origens!... Destacam-se o lirismo e a alegoria na canção: "Vão-se as teorias, apagam-se as constelações das idéias, parecem as fórmulas com o cérebro e nós, eternas como divindades - vivemos!” Apresentam-se alianças incomuns na formação de sintagmas provocando estranhamento e contribuindo sonora e inovadoramente para maior expressividade retórica e a seleção vocabular e sintática também atuam como elemento rítmico da frase: "E a vegetação do solo ubérrimo cresce como sempre, desordenada e festiva; o granito; e as rochas imortais amparam o zimbório das cavernas com o possante dorso, indiferente à vaidade das teorias.” Os adjetivos são cuidadosamente selecionados e trabalhados de maneira a dar maior expressividade ao eu poético.As percepções duais devido à utilização de oxímoros constantes são perceptíveis.

Pode-se constatar a repetição de determinados signos, que cumprem o papel de elementos de musicalidade no poema, do mesmo modo que se destacam a função rítmica e musical do verbo. "O cérebro ditava as leis; impunha-nos a geometria; marcava- nos o futuro, explicava-nos o passado!..”

A inovação na ordem das palavras e na pontuação expressiva são elementos do ritmo do poema: ”E a vegetação do solo ubérrimo cresce como sempre, desordenada e festiva; o granito; e as rochas imortais amparam o zimbório das cavernas com o possante dorso, indiferente à vaidade das teorias.”

O emprego dos tempos verbais, aqui no presente do indicativo, prevalecendo a figurativo, que vai atuar como elemento expressivo, retórico: "Moravam naquele crânio as teorias; havia nele idéias, como há constelações no éter; cada pensamento era um meteoro, relampeando naquele céu.”

O ritmo binário, as antíteses, “à beira do caminho, um túmulo campestre”, o paralelismo e a simetria predominam na maioria dos poemas em prosa de Pompéia, assim como é freqüente o uso de estruturas enumerativas, os cruzamentos e as combinações rítmicas. “Moravam naquele crânio as teorias; havia nele idéias, como há constelações no éter; cada pensamento era um meteoro, relampeando naquele céu”. 


\section{SOLUÇÃO XLIII}

Pára e retroceda, insensato!

Eu venho da grande viagem.

Desci ao fundo dos problemas; visitei, com o verme, as entranhas da terra; com o vendaval, os desertos; com os espectros, o coração da noite; com a estrela, o infinito; com os sonhos, o nebuloso passado! Deume luz o sol; deu-me vigor o penhasco; deu-me linguagem o trovão; deu-me energia o raio; deu-me asas o ciclone; deu-me arrojo o mar! Estudei, indaguei, ascultei, evoquei, observei. apostrofei, fui da apóstrofe à maldição; da maldição à blasfêmia! Aurúspice sacrílego, abri o ventre aos deuses! Sondei, sondei, sondei! Desafiei o gênio negro das metamorfoses; provoquei as vertigens do abismo!...

E o gênio negro respondeu:

“Nunca!”

E eu li no abismo:

“Nunca!”

(A Gazeta da Tarde. Rio de Janeiro, 28 de janeiro de 1886). 


\section{XI.III \\ solitio}

Pirin e retrocede, insensnlo!

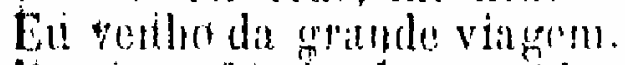

Desei a fumbo dus problumas; visitei, com o vermo, as entrahhis dia indar, com o vendaval, os desertos; com o leatu. os antros; con a arruia, a regia das tormentas; com os espectros, o corargio da noita cont astrelli, o intinito; com os sonhos, a nebuloso passiddo! binime luz o sol; deu-me vigur " junhaseo; detl-me lingrtagem o troval dentm: energia o riaio; deutme azas o cortome: den-me arrojo o nain' Estudei, intagrtei, auscultei, interpellei, eroquei, cbsecroi, apostrophei fui da apustrophe

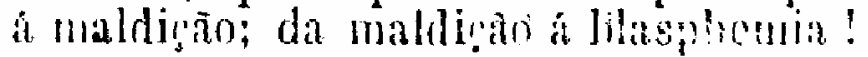
Auruspice sacrilogo, alni o ventria deuses! Sondej, sondei, sondei! Dresafiei o grenio negro das metamorpherses; provorguci as vertigens do alysuluis!...

Fo genio negrin respondlustme:

"Numca!"

Li eu li no abysmo:

( Acxis !n

Rur Punpis.

Figura 9: Solução.

Fonte: A Gazeta da Tarde, 28 jan. 1886.

Apesar do nome, o poema em prosa mostra idéias contraditoriamente sem solução. Fala da caminhada existencial e das experiências vividas, tudo em vão. Todas as ações são inúteis e conduzem ao abismo. "Desafiei o gênio negro das metamorfoses; provoquei as vertigens do abismo.”/“E o gênio negro respondeu-me:/‘Nunca!’ /E eu li no abismo: ‘Nunca’””

Podem ser observados elementos científicos, materiais em contraposição a elementos idealizados, como exemplificamos: "Deu-me luz o sol; deu-me vigor o penhasco; deu-me 
linguagem o trovão; deu-me energia o raio; deu-me asas o ciclone; deu-me arrojo o mar!” Todo o poema constitui-se de uma rede de metáforas ligadas a questões metafísicas. E o próprio título traz implícito um oxímoro: solução (vã ou sem solução).

Segundo Todorov, a metáfora em sentido lato é a característica fundamental da linguagem poética e este fato é constante das Canções sem metro. Como dissemos anteriormente, nesta análise observamos, particularmente, seus símbolos recorrentes, que constituem módulos paradigmáticos: elementos da natureza, os animais, os astros, elementos horizontais em contraposição aos verticais, concretos e abstratos, materiais e metafísicos, todos presentes em seus textos formando a estrutura da maioria de suas composições em prosa poética.

A preferência pelas construções nominais própria do estilo impressionista está sempre presente, assim como o lirismo e a alegoria (...) visitei, com o verme, as entranhas da terra; com o vendaval, os desertos; com os espectros, o coração da noite; com a estrela, o infinito; com os sonhos, o nebuloso passado!”

Neste texto a repetição de verbos atua como elemento rítmico da frase: "Deu-me luz o sol; deu-me vigor o penhasco; deu-me linguagem o trovão; deu-me energia o raio; deu-me asas o ciclone; deu-me arrojo o mar! Estudei, indaguei, ascultei, evoquei, observei. apostrofei, fui da apóstrofe à maldição (...)”.

Os nomes abstratos e os temas metafísicos ligados à cosmologia que se destacam neste poema em prosa e, mais uma vez, há alianças incomuns na formação de sintagmas provocando estranhamento e contribuindo sonora e inovadoramente para maior expressividade retórica. Também, a seleção vocabular e a sintática servem como elemento rítmico no texto. Há inovação na ordem das palavras e na pontuação expressiva.

As percepções são duais devido à utilização de antíteses constantes. As enumerações relativas à "grande viagem” atuam como elementos de musicalidade no poema, os verbos têm função rítmica e musical. As frases curtas e a pontuação também contribuem para a expressividade retórica do poema, sugerindo ao mesmo tempo muito movimento, ações inúteis, para uma busca sem solução. E todos estes recursos estilísticos comprovam a forma inovadora de grande valor literário criada por Pompéia. 
Em relação ao cruzamento com a linguagem jornalística repetem-se as características que distinguem as canções em prosa poética de Pompéia: divisão triádica e piramidal do relato, clareza, brevidade, tudo imbricado ao extremo lirismo poético que dificulta perceber o cruzamento das duas linguagens que se interpenetram.

\section{TORMENTA E BONANÇA XLIV}

Tabernáculo abandonado dos velhos deuses! vociferava o mar tormentoso tormenta. Céu profundo! Morada do mistério e do terror! De que val a miríade dos astros? É mais tenebroso o teu seio que as insondadas cripas das minhas profundezas!

Oceano etéreo, onde nadam os mundos! Que ignotos litorais restringem o teu âmbito incalculável?

Onde vão parar as estranhas ondas e as correntes e os turbilhões que te convulsionam a espessura?

Donde despedes o golpe do furacão que lacera as vagas?

Os homens, meus irmãos, desesperam-se comigo e interrogam. À voz dos profetas, acobardaram-se, refugiaram-se nos templos; tentaram vencer-te pela sedução do holocausto. O fumo das aras perdeu-se inútil na imensidade.

Aos homens replica o sarcasmo perene da morte...

Que mão é esta que trucida os homens, que flagela as vagas?

Onde acoutas, ó céu! esse fantasma adverso que os fere, que me fere?!

Serenou o mar; estendeu-se-lhe, à superfície, a calma da prostração e o silêncio.

Flutua-lhe, à tona, a vasta tristeza habitual - decepção perpétua das perpétuas audácias do oceano.

(A Gazeta da Tarde. Rio de Janeiro, 29 de janeiro de 1986). 


\begin{tabular}{|c|}
\hline 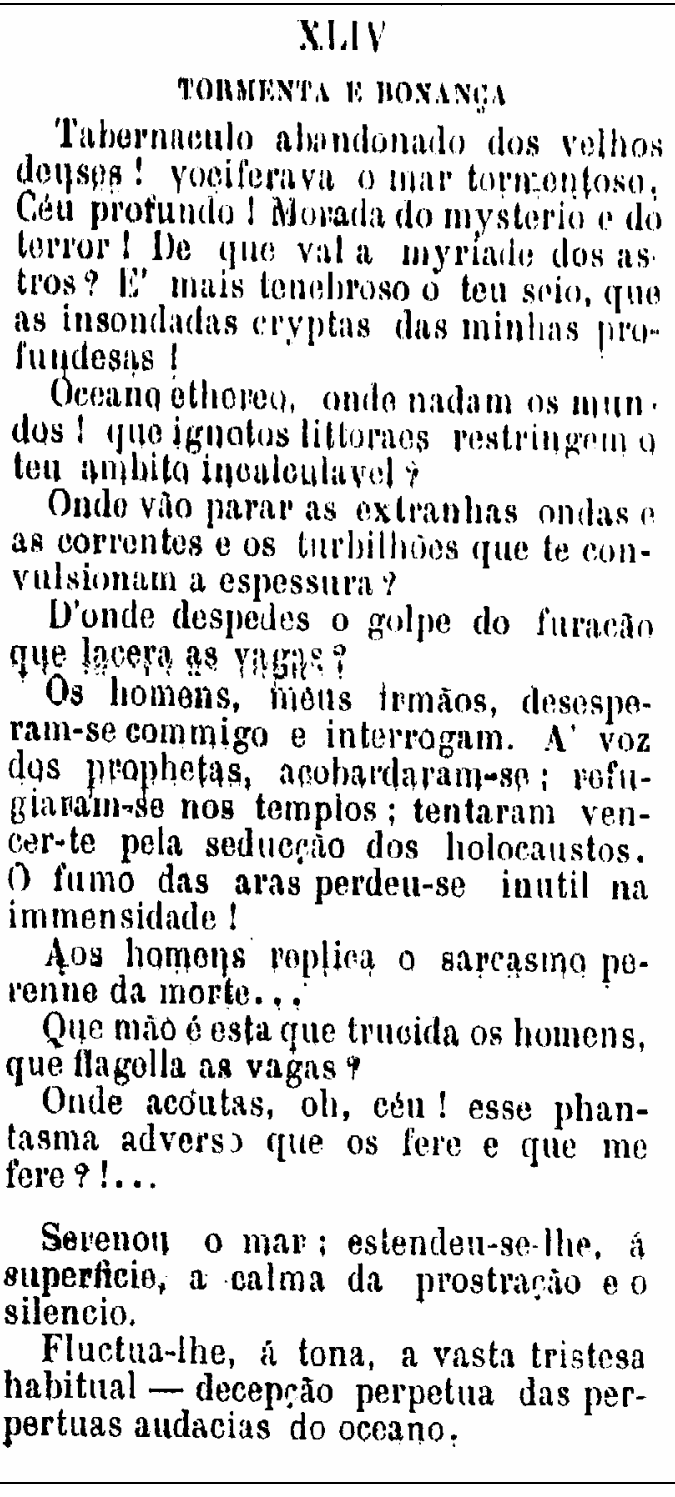 \\
\hline
\end{tabular}

Figura 10: Tormenta e Bonança.

Fonte: A Gazeta da Tarde, 29 jan. 1886.

Mais um título de contradição, sem a síntese dialética. A tormenta refere-se ao elemento “mar” tormentoso. O símbolo mar = água diz respeito à vida e às suas intempéries. "Os homens, meus irmãos, desesperam-se comigo e interrogam. À voz dos profetas, acobardaramse; refugiaram-se nos templos; tentaram vencer-te pela sedução dos holocaustos. O fumo das aras perdeu-se inútil na imensidade! Aos homens replica o sarcasmo perene da morte...” 
Ao final, "serenou o mar; estendeu-se-lhe à superfície, a calma da prostração e o silêncio”. Mas “flutua-lhe, à tona, a vasta tristeza habitual - decepção perpétua das perpétuas audácias do oceano”.

Aqui também a seleção vocabular e a sintática funcionam como elemento rítmico da frase. "Tabernáculo abandonado dos velhos deuses! vociferava o mar tormentoso tormenta. Céu profundo! Morada do mistério e do terror! De que val a miríade dos astros? É mais tenebroso o teu seio que as insondadas cripas das minhas profundezas!”

As orações interrogativas e as combinações com o adjetivo têm função preponderante no ritmo melódico da canção. “Oceano etéreo, onde nadam os mundos! / Que ignotos litorais restringem o teu âmbito incalculável? / Onde vão parar as estranhas ondas e as correntes e os turbilhões que te convulsionam a espessura? Donde despedes o golpe do furacão que lacera as vagas?” Presentificam-se, também, os neologismos do significado. Há inovação na ordem das palavras e na pontuação expressiva. "Onde acoutas, ó céu! esse fantasma adverso que os fere, que me fere?! / Serenou o mar; estendeu-se-lhe, à superfície, a calma da prostração e o silêncio.” Percebe-se ainda, vários símbolos ligados ao espaço físico e metafísico. Esse recurso estilístico é acentuado com a repetição freqüente do interrogativo: “onde”, “d’onde”.

Os verbos têm função rítmica e musical. “Os homens, meus irmãos, desesperam-se comigo e interrogam. À voz dos profetas, acobardaram-se, refugiaram-se nos templos; tentaram vencer-te pela sedução do holocausto. O fumo das aras perdeu-se inútil na imensidade. / Aos homens replica o sarcasmo perene da morte.”

Aparece a repetição de determinadas palavras, como elementos de musicalidade no poema. "Flutua-lhe, à tona, a vasta tristeza habitual - decepção perpétua das perpétuas audácias do oceano.”

Percebe-se a presença das construções nominais de influência impressionista "Tabernáculo abandonado dos velhos deuses! / Céu profundo! Morada do mistério e do terror!”

Os nomes abstratos, o lirismo e a alegoria compõem o poema. “ Flutua-lhe, à tona, a vasta tristeza habitual - decepção perpétua das perpétuas audácias do oceano.” 
Há, ainda, a presença de temas metafísicos ligados à cosmologia; “Oceano etéreo, onde nadam os mundos! Que ignotos litorais restringem o teu âmbito incalculável?”

A prosa poética se concretiza pela harmonia imitativa, pela aliteração, pelo uso da repetição como agente lírico, pela beleza das figuras, pelo estilo inimitável do talentoso escritor. "Tormenta e Bonança” é mais um oxímoro, expresso pela linguagem literária de Pompéia que contrapõe elementos materiais a elementos idealizados, faz uso freqüente do ritmo binário, das antíteses, do paralelismo, da simetria, dos padrões melódicos, compondo grandes estruturas rítmicas em sua prosa poética ligada ao jornalismo e à literatura. "Serenou o mar; estendeu-se-lhe, à superfície, a calma da prostração e o silêncio./ Flutua-lhe, à tona, a vasta tristeza habitual - decepção perpétua das perpétuas audácias do oceano”. Percebemos o nível narrativo imbricado ao poético, “tabernáculo abandonado dos velhos deuses! vociferava o mar tormentoso tormenta. Céu profundo! Morada do mistério e do terror! De que val a miríade dos astros? É mais tenebroso o teu seio que as insondadas cripas das minhas profundezas!” e a divisão piramidal defendida, por Vivaldi (1979): a primeira parte compreendida pelas perguntas do ser de enunciação; a segunda, a reflexão e o questionar filosófico do autor e a terceira parte a volta à calma, ao silêncio, nos dois últimos parágrafos.

\section{CONCLUSÃO XLV}

Serenou o mar...

Tornou também o firmamento à limpidez da bonança. Ao mar e aos homens apareceu, sem mácula, a vastidão do azul.

Sem mácula!

Pode vir, de novo, a coorte dos nimbos repetir o drama da tempestade. Pode vir a estrela e continuar a existência nômade que leva!

Para a nuvem, risonha ou trágica, sombria ou luminosa, pejada de raio ou penetrada de luar, lá está o cenário franco. Para o astro, impassível, lá está o rumo das órbitas desimpedido!

Estrela, nuvem... 
Sobre o céu eterno destaca-se bem a antítese destas criações diversamente efêmeras do Mistério.

É a lição definitiva da natureza!

Ressalta, em vivo contraste, sobre o fundo obscuro do tempo intérmino - a uniforme niilidade dos múltiplos aspectos combinantes das existências.

O céu, como uma fábula, tem esta moralidade.

(A Gazeta da Tarde. Rio de Janeiro, 29 de janeiro de 1886).

\section{XIS}

(i)vilusin

Serrnoll o mar...

'Tornon tambern o firmamonlo a limpidoz da boultrea.

Ao matr o ans loumens apparegan, sem manida, a vastidian do azid.

Sem macula!

Póte vir, de novio, a cohorte dos nimbos repmetir o dramia da tempastade. Podo vil a cstrilla o bontinuar a existencia nomade cue leva!

Parit il nuvem, pisonha on tragioa, sombria, ou luminosn, pejada do ratos ou pentrada de luar, la está o scenario frinco. Para o astro, japassivel, la esta o rumo dar or bitas ingingadida!

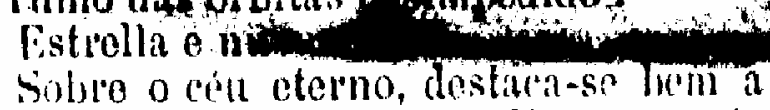
antilhese destas crearia's diversamente aphemeras do Mystirio.

I: a liceito definitiva da nalurea!

Resalti, on vivo contraste, solno o funco olseriro do tempo inlermino-a uniforme nihilitade dos maltiplos aspectus cambiantes das exietoncias.

() cen, como uma fabula, tem essit monilitinl!.

$$
\text { Rave Pontas. }
$$

Figura 11: Conclusão.

Fonte: A Gazeta da Tarde,.29 jan. 1886. 
Uma profusão de símbolos “mar”, “tempestade”, “estrela”, “nuvem” e a presença de inúmeros recursos visuais na linguagem poética do autor remetem-nos à serenidade ou à bonança do mar que ressurge "sem mácula” e em sua "vastidão do azul”. A tempestade pode se repetir, assim como os símbolos "estrela” e "nuvem” podem prosseguir cumprindo suas funções específicas: de nômade, a primeira, símbolo do sonho inatingível; de instabilidade efêmera, a nuvem “risonha ou trágica”, “sombria ou luminosa”, “pejada de raios ou penetrada de luar”."Estrela e nuvem... Sobre o céu eterno, destaca-se bem a antítese destas criações diversamente efêmeras do Mistério.É a lição definitiva da natureza!”

Percebemos nesta canção a escolha das alianças harmoniosas e subjetivas entre a representação e a sugestão, principalmente na seleção dos símbolos. O texto anterior, “Tormenta e Bonança” e este aqui, “Conclusão”, contradizem o pessimismo existente na idéia do eterno fracasso do mar em sua luta. O tema de “Os continentes” é justamente o desaparecimento de Atlântida sob as águas do oceano e o tema dos dois últimos textos é o cataclismo final, que destrói a civilização e promove o retorno ao tempo da origem: "Serena o mar... / Torna também o firmamento à limpidez da bonança. Ao mar, aos homens, reapareceu, sem mácula, a amplidão do azul".

Os oito poemas selecionados do periódico pertencem, como já explicitado, à última parte do livro, "Infinito”, Estes poemas estão mais ligados às preocupações metafísicas do autor, sempre questionando o universo que o cerca. Constituem, ainda, modelos inquestionáveis de prosa poética, talvez em decorrência de maior maturidade do escritor, à época. Nesse corpus o poeta percebe que há uma eloqüência maior que o rumor do sintagma e oxímoro "Rumor e Silêncio”, uma vez que esse rumor inclui o tempo tridimensional. Todavia, o poema em prosa “Vulcão Morto” reafirma a realidade do desaparecimento desse tempo presente.

Não só a história, mas o mundo material também espera sua destruição, como percebemos em “Os Continentes”. Outra metáfora dessa destruição final que aguarda tudo que existe são os túmulos, ante os quais só permanecem as estrelas, símbolos do infinito, do sonho inatingível, passageiro “Transit”.

O fracasso final do pensamento humano cantado por Pompéia pode ser percebido em “Solução,” que atinge a natureza, no poema seguinte, “Tormenta e Bonança”, no qual tudo é 
nulo contra o fundo do tempo, canta o poeta em “Conclusão”. Na percepção do poema, o amontoado de palavras a que foi reduzida a impressão veiculada, por meio do sonho de eternidade, as estrelas, face ao infinito, é também inalcançável, pois elas cintilam distantes e frias, indiferentes, apesar da luz.

Percebe-se, então, que todo o processo de criação, em todos os seus prismas e perspectivas, é mera contradição, um oxímoro que se resolve apenas como um desejo de criação contra a impotência infinita. Deduzimos, portanto, que a criação artística também fica reduzida à contradição do inútil desejo de perenidade, o oxímoro que muitas vezes leva a nada ao final.

Resumindo, podemos dizer que o antagonismo entre os componentes desse gênero híbrido prosa e poesia -, da nomenclatura genérica baudelairiana, presente na idéia da canção a qual falta métrica, no sentido de ritmo, só se resolve pela constatação final da nulidade de ambos, ou seja, tese e antítese, em vez de síntese, conduzem ao nada. “O céu, como uma fábula, tem essa moralidade” é a constatação do último poema, Conclusão, das canções de Pompéia. Ante a infinitude do cosmos, "onde os cometas cruzam-se como espadas fantásticas de arcanjos em guerra," tudo na Terra é ínfimo e mortal, tanto o tumulto dos cataclismos como o das revoluções, inclusive as conquistas humanas.

O autor trabalhou incansavelmente na criação de um gênero inovador, mas por meio do eu poético expressa sua descrença, por não perceber a saída para a efemeridade da transformação do cosmos. Heidegger encontra a possível saída na linguagem artística e em uma das canções que comentamos genericamente há um vislumbre semelhante, quando Pompéia exalta a arte.

Alguns artistas tentam encontrar as leis de organização de uma forma não muito distanciada do poema em verso, com sua ordem cíclica de simetrias métricas e sonoras; por outro lado, os poetas daquela época de transição, o final do século XIX, caminham para um projeto poético mais original, na expectativa de violentar a ordem estabelecida e, através da superação, atingir a conquista de um gênero novo, surpreendente, a exemplo de Pompéia. Nessa revolução poética predomina uma característica em que as palavras formam as constelações de imagens que vão criar uma atmosfera interior em síntese altamente simbólica e metafórica, conforme vimos nas canções em prosa poética de Pompéia. 
Nas Canções sem metro, percebemos uma espécie de tragédia dos ideais e o eterno ciclo da história, sobretudo nos textos que selecionamos como os mais representativos. Além de se fazer presente em diversos motivos temáticos e em algumas formas composicionais, ela também orienta a organização dos poemas, conferindo uma estrutura cíclica ao texto. Entre os motivos que nos remetem à concepção decadentista da História, o mais significativo é o do ciclo dos movimentos naturais, do dia e da noite, das estações, ou do nascimento e morte dos seres vivos, associado à questão básica da efemeridade da vida.

Numa leitura completa dos textos em prosa poética de Pompéia, constatamos que esse motivo se encontra presente principalmente na segunda parte do conjunto, sob o título, "Amar" e composta pelos poemas "Inverno", "Primavera", "Verão", "O outono" e "Ilusão renitente". Esses poemas embasam a alegoria do tempo histórico cíclico, estabelecendo uma analogia entre as fases de desenvolvimento dos seres vivos e as fases de desenvolvimento das civilizações. Essa temática é base central no poema "Os continentes", analisado neste capítulo. Ali, o ser de enunciação canta em desespero por um sinal de Atlântida, inconformado com o seu desaparecimento.

Dando continuidade ao tema central de "O mar", que simboliza a dominação da natureza, encontramos uma relação intertextual que acentua o significado de fracasso do projeto divino da criação humana. Assim, como lemos em Gêneses (VI, 5 a 7), os resultados dos desígnios de Deus são contrários ao espírito da criação, uma vez que o homem se apossa da natureza não objetivando à felicidade e à concórdia da espécie, mas visando ao poder, na sua satisfação da luxúria e da ganância. Ele se apossa, igualmente, das qualidades dos animais que cada um julgava serem as melhores atribuídas pelo criador; da natureza inorgânica, ele se apossa dos minerais para satisfazer os instintos da nutrição e do amor exacerbados pela imaginação doentia e egoísta da espécie, uma vez que voltados à luxúria e ao crime.

Conseqüentemente, o resultado da luta entre o bem e o mal, que habitam o interior do homem e que constituem a hybris ou desmedida causadora da sua tragédia, é uma narrativa histórica marcada por um pólemos (KOTHE, 1987) às avessas, pois o declínio dos ideais do belo e do justo ocorre em proporção inversa à ascensão da indústria e da barbárie, "ao esforço dos tiranos e conquistadores, que recortaram à ponta de espada as linhas geográficas do mapamundi e sedimentaram as camadas sociais, segundo a mecânica do egoísmo" (1981, p. 207). 
A concepção mítica do tempo é constantemente reafirmada em Canções sem metro, uma espécie de escatologia sem divindades, encontrando-se não somente em inúmeros poemas como na possível conclusão da obra. No seu final, novamente somos remetidos ao estado inicial do mundo, quando o mar e a amplidão azul encontravam-se desprovidos de máculas e o primeiro, ainda implacável, era capaz de erguer a sua cólera contra a maldade e a ganância dos homens - conforme lemos no poema "O mar" (primeira canção da parte III, intitulada "O ventre"), cuja epígrafe em livro é retirada do "Gêneses" (cap. 7, 22): "Et cuncta, in quibus spiraculum / Vitae est terra, mortua sunt" (apud POMPÉIA, 1982, p. 63). "E onde existe um sopro de vida, há morte” (Trad. Nossa).

Ao final da obra, no penúltimo poema, constante do corpus priorizado para análise "Tormenta e Bonança", novamente encontramos o tema do cataclismo resultante da revolta das águas contra os "ignotos litorais" (1982, p. 99) que o limitam. Após a tempestade, retorna "o firmamento à limpidez da bonança. Ao mar, aos homens, reapareceu, sem mácula, a amplidão do azul" (1982, p. 100), conforme lemos no último poema que, não por acaso, chama-se "Conclusão". Apesar da luta sem fim que caracteriza a história da humanidade, todo o esforço humano em direção ao progresso parece inútil. Até mesmo a esperança de uma aurora, símbolo de uma possível revolução, capaz de libertar a humanidade, é uma ilusão. Assim como Prometeu, ela está condenada ao sofrimento eterno decorrente do desejo de igualar-se aos deuses e de desvendar o grande mistério da existência. Vejo, aí, alguma esperança, porque na mitologia, Prometeu, o símbolo do social, foi liberto, mesmo muito tempo depois, ao contrário do Sísifo, que pode ser visto como o símbolo transcendental, inatingível.

Esta temática ligada dialogicamente ao Romantismo encontra-se bastante visível nos poemas "Transit" e "Solução", também constantes de nosso corpus e "Mefistófeles", da parte IV, do livro, intitulada Vaidades. Em "Solução", o personagem do "gênio negro", alusão ao Mefistófeles de Fausto (GOETHE, 2003) nega ao homem a possibilidade de ele desvelar e dominar o universo. Em "Mefistófeles", o tema é semelhante. Ali, o ser de enunciação que podemos associar ao personagem referido no título, questiona a ambição de Fausto, colocando em xeque todo o seu esforço intelectual: "Em que deram tantas canseiras espirituais? A contemplação da luz deixou-te cego! Anda, pois! Desiste do empenho... [...] A inteligência, queres saber! É o próprio inferno" (1982, p. 78). Segundo Lopes e Silva (2004), se 
considerássemos a constante intertextualidade das canções com a bíblia, sobretudo com o capítulo XIX dos Salmos, poderíamos concluir que a Filosofia da História implícita nas Canções sem metro é essencialmente cristã, o que não seria verdade. A preocupaçãp de Pompéia não está ligada a determinada crença religiosa, mas ao anseio por liberdade, pelo absoluto, pelo infinito.Por isso a sua necessidade de compor as suas Canções sem metro.

Ao longo da leitura crítica, de Canções sem metro, percebemos que o movimento cíclico da história e da existência humana é semelhante aos ciclos da natureza, na qual nascimento e a morte se sucedem infinitamente numa "maternidade sem ventura" (1982, p. 57). De tal modo que o destino do amor e da vida é "arder, arder e morrer, como o fogo que cresce, cresce e, de si mesmo, morre" (1982, p. 56), sem que o ser humano possa compreender por que "renasce do triste inverno a verde primavera" (1982, p. 57).

Da mesma forma que se extinguem "para sempre os castelos de chamas que se erguiam sobre a cratera" de "Vulcão morto", extinguem-se igualmente as grandes civilizações, como Atlântida, em "Os continentes", (esses dois poemas são constantes do corpus) e o antigo império egípcio "Deserto", (p. 84) do livro. As pirâmides em meio ao deserto não são apenas ruínas que nos lembram a fugacidade de todas as coisas, mas são também imagens simbólicas da história em seu eterno movimento de ascensão e decadência. Nesta escatologia sem deuses e sem redenção, o homem, como parte da natureza, escapa às leis do movimento universal, essas leis são as responsáveis pelas correspondências entre todos os elementos cósmicos.

De qualquer forma, podemos comprovar pelo estudo de seus textos que Pompéia quis fazer uma obra orgânica, representativa da visão totalizante do universo, lírica e filosófica ao mesmo tempo, do ponto de vista do homem pessimista, do final do século XIX, descrente das conquistas científicas e perdido diante do imenso abismo de interrogações que o desafiam. Quis desenvolver o gênero inovador, a exemplo de outros expoentes na Europa, trabalhou árdua e persistentemente e o conseguiu.

Sua poética esteve sempre aliada à imprensa, como cronista, autor de romance folhetim, além das Canções sem metro que foram realmente sua obra prima. Todos seus textos apresentam qualidades inatas dos grandes escritores ou jornalistas. Grande espírito de observação, visão clara das coisas; excelente reflexão, na análise dos fatos; objetividade, 
devido à sua mentalidade científica, mesmo com o subjetivismo do poeta, capacidade de exposição detalhada do mundo. Suas canções apresentam unidade, do princípio ao fim, de acordo com sua visão de mundo que implicava a busca de uma cosmologia. E as Canções sem metro, de Pompéia, demonstram claramente que o seu autor consegue incorporar num plano estético, dentro do projeto literário brasileiro que ele integra os problemas que a modernidade vivencia nas letras. 


\section{CANÇÕES SEM METRO: INTRADIALOGISMO ENTRE CANÇÕES DO LIVRO E DO PERIÓDICO A GAZETA DA TARDE}

A primeira diferença que percebemos entre as canções constantes do livro e as do periódico são as epígrafes que aparecem em quase todos os textos reunidos em livro. Dos oitos textos priorizados para análise no corpus da pesquisa, apenas uma das canções, “Solução”, não traz uma epígrafe. O livro como obra total apresenta uma epígrafe geral e trata-se de um texto de Paul Pierson que diz: “as palavras que compõem o verso não têm em si mesmas nenhuma medida determinada; elas só a apresentam a partir do momento em que são pronunciadas num tempo medido; o que é medido não é, então, o verso, mas o tempo e a ciência da medida, a métrica, tal como a entendemos em seu sentido verdadeiramente geral e científico, pode-se aplicar a toda medida de tempo, qualquer que seja o agente rítmico, dança, canto ou palavra”.

Esse texto vem de um livro publicado na coleção que a escola de Altos Estudos do Ministério de Instrução Pública da França fazia editar e tem a introdução de Gaston Paris, talvez o mais respeitado filósofo europeu de sua época. Paul Pierson morreu alguns anos antes da época literária de Pompéia, aos 29 anos e sua obra, cujo valor consiste apenas em seu sentido instigador, é uma tentativa de identificar as leis que regem a estruturação da expressão natural. A idéia vem da impressão de Pierson de que há um certo ritmo que corresponde a cada uma das expressões que se deseja transmitir. Este ritmo pode ser definido por meio do recurso às leis da composição musical. Segundo aquele pensador, assim, a arte da métrica poderia se transformar em uma ciência.

Essas idéias podem ter sido julgadas importantes por Pompéia, pelo seu caráter de modernidade à época, assim como pela tentativa, comum aos sistemas racionais do século XIX, de reduzir a complexidade geral a algumas linhas simples e elegantes.

As epígrafes mostram o cuidado do autor em sua seleção. Pompéia retirou as epígrafes da bíblia, de alguns poetas medievais, como Dante e Shakespeare, do pintor e alegorista Proud hon, de Leopardi, Victor Hugo, Heine, Espronceda e dois regionalistas exarcebados (Verdaguer e 
Brizeux) e elas servem de suporte para o seu objetivo, a construção de um novo gênero, a prosa poética no Brasil, numa afirmação das contradições e da permanência do cânone ocidental. Nesta primeira canção a épigrafe é do Conde Giácomo Leopardi (1798-1837), escritor italiano, desiludido com o amor e a com a política mergulhou em desolada solidão. Escreveu: A Itália (1918), Poesias líricas (1824-1835), Canto noturno (1831), A Giesta (1836).

\section{RUMOR E SILÊNCIO}

- Cosi tra questa

Immensitá s’annega il pensier mio;

E il maufraga m'e dolce in questo maré.

G. LEOPARDI - L'infinito. “Ouvis, lá abaixo o rumor da cidade, a grita dos homens, o estridor dos carros, o tropel dos ginetes, o fragor das indústrias? Ouvis de outra banda a voz do arvoredo, os pássaros saudando a tarde, pó vento angustiado a harpa cólica das frondes? Ouvis esse clamor ingente que as ondas mandam? É a sinfonia da vida.

Diz-se então que o silêncio é a morte.

Multiplicai esses rumores. Agravai o tumulto industrial dos homens na paz com as perturbações estrepitosas da guerra; reforçai as vozes da floresta e do mar, juntai-lhes a solene toada das catadupas, o pungente mugir dos oceanos lanceados pelo temporal, as explosões elétricas do raio, a crepitação fragorosa dos gelos derrocados pelo sopro da primavera polar, o garganteio monstruoso dos vulcões inflamados; fazei rugir o coro das catástrofes humanas e dos cataclismos geológicos.

Dizei, depois, onde mais intensa é a vida e maior o assombro, se embaixo ou em cima, no zimbório diáfano que a noite vai conquistando agora, na savana imensa onde transita a migração dos dias e viajam as estrelas, onde os meteoros vivem, onde os cometas cruzam-se como espadas fantásticas de arcanjos em guerra - na mansão dos astros e dos sagrado silêncio do infinito?!”.

No uso da sonoridade das palavras e de suas combinações pelas ressonâncias de natureza psicológica que suscitam, o escritor consegue efeitos de evocação musical bem sugestivos. A estrutura das frases expressa tendência para as formas regulares que indicam uma intenção de 
produzir cadências métricas e estróficas. As simetrias, os paralelismos e as enumerações provocam uma certa sonoridade compassada, irregular, sugerindo uma atmosfera poética. O ritmo e as medidas silábicas da frase são instrumentos da criação de um clima sutil de ressonâncias líricas. Ao longo de sua produção vai aumentando o elemento musical como recurso técnico que vai trazer a cumplicidade dos sentidos do leitor, conduzindo-o ao universo particular de sua criação, ao movimento lírico em que nasce a idéia no espírito do autor. Por meio de uma variada utilização de valores fônicos das palavras, Pompéia consegue associar significado e som e percebe-se em cada idéia e emoção a correspondência com a melodia e o ritmo dando expressividade à construção inovadora do gênero misto que se propôs desenvolver com sua disciplina e individualidade artística. O poema,”Rumor e silêncio”, aqui, mantém o mesmo título do texto original do periódico. Há o acréscimo da epígrafe (palimpsesto), de Leopardi, extraída de L'infinito, de acordo com o tema que nomeia a quinta parte do livro Canções sem metro. Há a presença de figuras belíssimas e o tema divide-se na antítese Rumor e Silêncio, paradoxalmente correspondentes à vida e à morte. A temática básica em ambas as versões é o questionar: se a vida é mais intensa na eternidade, - "abismo discreto habitado pelos astros e pelo silêncio sagrado do infinito -, ou, na versão em livro, “na mansão dos astros e do sagrado silêncio do infinito”.

Houve mudança no layout do texto, na pontuação, substituição em nível paradigmático. O resultado é uma linguagem mais sutil, o conteúdo é sempre o mesmo, mas percebe-se que passou por grande processo de burilamento e ele parece mais literário, menos jornalístico, causando menos impacto.

\section{VULCÃO EXTINTO}

E quel medesmo, Che si fue accorto

Chi'io dimandava il mio Duca di lui

Gridò: Qual i’fui vivo, tal son morto!

DANTE - Divina Commédia. 
“Rasga-se a cratera à sombra do píncaro mais alto. Precipícios sem fundo; vai-se-nos a imaginação pelas fragas, a perder-se embaixo, impenetrável noite.

Antes de tombar sobre o vulcão este silêncio pesado, quanta vez tremeram as rochas ao rugido da lava fervente! Tentara o gigante em outros tempos incendiar a amplidão: o século o puniu.

Nada mais ficou dos grandes dias além das escarpas calcinadas, o velho esqueleto informe.Caíram para sempre os castelos de chamas que se erguiam sobre a cratera; extinguiram-se de vez as cenografias satânicas da conflagração; pereceu a memória das erupções triunfais!

Tudo agora está findo.

E para os espaços arreganha-se o caminho das lavas, imensa boca torcida na expressão de atroz agonia brado estrangulado pela morte, apóstrofe muda e terrível, blasfêmia misteriosa da terra”.

Novamente, temos a presença de uma epígrafe nessa versão em livro. Como em quase todos os poemas do corpus, na sua versão em livro, este texto também apresenta um paratexto, aqui em italiano, cujo final significa "fui vivo e agora estou morto" (trad. nossa). O autor é Dante Alighieri (1265 -1321), poeta italiano, diplomata, idealista, buscou uma forma nova na lírica, menos erudita, autor de a Divina comédia (1307) que transfigura no plano poético não apenas sua própria vida, mas todo o universo contemporâneo.

A tendência de Pompéia para a disposição binária dos elementos e para a simetria, faz com que ele combine as técnicas de composição com harmonia verbal, provocando efeitos sonoros duplos que vão realçar a oposição de idéias e as sensações. Esta versão apresenta mais frases nominais e vocabulário menos erudito. Todavia, o conteúdo é o mesmo, apesar da substituição de expressões, de palavras e duas frases a menos no total da composição. O adjetivo do título do poema é trocado: "Vulcão Morto", no original, agora "Vulcão Extinto". A temática está relacionada ao texto anterior, trazendo como idéia básica a sugestão da epígrafe. Tudo que é vivo perecerá, como "os castelos de chamas" dos vulcões, em erupção. Talvez, devido a uma "misteriosa blasfêmia arrojada, das entranhas da terra, à imensidade".

Além da substituição de algumas palavras: "extinto" e "findo" em vez de "morto", mudança na pontuação, paragrafação, no layout do texto, percebe-se o burilamento do texto que se torna mais lírico nesta versão de livro, mais sutil. 


\section{OS CONTINENTES}

?Hont ets? - Y ay! Hont l'hermosa

solía'ls cars atraure,

lo pìlach responía: - Yo l’he engolida á nit;

feste enllá les terres per sempre

'm vull ajaure;

man llit; ay d'elles! Ay si 'm also per

dixamplar.

J. VBERDARGUER - La Atlántida.

Atlântida! Atlântida!

Onde estão agora as florestas, as torrentes caudais, as cidades, os reinos? Onde os homens, os rebanhos, as ferras? Monumentos, grandeza, poderio, exércitos, e as gloriosas artes?... Onde jaz sepultado o gênio humano, fertilizador das regiões desaparecidas? Que é feito das próprias ruínas? Como foram consumidos os venerandos restos da arquitetura - fustes truncados, capitéis caídos? E os túmulos? As ossadas dispersas, que vão ficando das gerações no roteiro dos séculos? A própria morte morreu. E as montanhas, que suspeitávamos eternas, na audaciosa majestade da pedra, familiares entre a águia e o raio, como Júpiter Deus?!

Os monstros sabem talvez - os monstros do mar profundo, que nadam lendo pelos escombros imersos, o olhar pávido, na transparência noturna do abismo; mas guardam tenazmente o formidável segredo do seu espanto.

A face do oceano é muda como o mármore sem inscrições.

Debalde o sol agride com os raios irreverentes da luz a superfície da campa amplíssima. Os raios quebram-se, repelidos pela discrição lapidária do mistério. Debalde a tormenta devasta e sulca, chacal sacrílego! Com as furiosas garras a espessura esmagadora que se acama sobre o continente submergido.

Terror perene e indefinível dos continentes vivos: a interrogação permanece. 
Esta epígrafe é de Jacinte Verdarguer (1845-1902) poeta catalão, autor de dois grandes poemas épicos que reúnem os mitos antigos, as lendas locais e o maravilloso cristão: A Atlântida (1877) e Canigu (1885).

Às vezes a repetição de determinada comparação é reforçada pela introdução do nome abstrato da qualidade comparada. Os recursos não são produtos do acaso, nem da consciência criadora. A obra está escrupulosamente planejada. A técnica da repetição contribui para a arquitetura da prosa poética até hoje despercebida na leitura desatenta e, portanto, não estudada pela crítica que ainda não valorizou esses fenômenos idiomático-estilísticos. Este poema,"Os deuses" tem sua epígrafe extraída de El Diablo mundo de José de Esprocenda (apud POMPÉIA, 1982, p. 95) e aponta para o tema das crenças religiosas consideradas como ilusões: "Las creencias que abandonas, / Los templos, las religiones / Que pasaron, y que luego / Por mentira reconoces, / Son, quizá, menos mentira / Que las que ahora te forges?". No lugar de Deus, o locutor crê no sol, "no astro onipotente, criador dos dias e das cores" (1982, p. 95): Que estranha potestade és tu, glorioso sol que me deslumbras?! Sem a tua presença toda esta paisagem jazera morta. Toda esta alegria me acorda o sangue e um vivo eflúvio de fulgor, astro onipotente, criador das cores e dos dias! Ah! Eu adoro o sol que é a força. Vem do mistério como os deuses e, como os deuses vem, como os deuses, vai para o mistério. Por que buscar mais alto a Divindade?! (1982, p. 95). Percebemos o mesmo tipo de alterações: substituição de termos, palavras, mudança de pontuação, de layout, verdadeiro processo de burilamento que torna o texto mais literário.

\section{OS DEUSES}

CREDO SOLAR

Las creencias que abandonas,

Los templos, las religiones

Que pasaron, y que luego

Por mentira reconoces, 
Son, quizá, menos mentira

Que las que ahora te forges?

J. de ESPRONCEDA -

El Diablo mundo.

Donde vens, divino sol? Que ideal te propele à infinita jornada?

Vê! Teus raios penetraram a natureza como uma vida nova; sob o teu olhar, o magnânimo universo ressurge e rejuvenesce. Ouve! Há risos sob a relva e canções no arvoredo! É teu o ouro das asas do inseto; o verde dos bosques é teu; é teu o azul dos espaços. Todas estas pétalas que resplendem iriadas, recamando os prados, foram todas elas coloridas sob o minucioso pincel formado dos teus raios.

Que estranha potestade és tu, glorioso sol que me deslumbras?

Sem a tua presença toda esta paisagem jazera morta. Toda esta alegria me acorda o sangue e um vivo eflúvio de fulgor, astro onipotente, criador das cores e dos dias! Ah! eu adoro o sol que é a força. Vem do mistério como os deuses e, como os deuses vem, como os deuses vai para o mistério. Por que buscar mais alto a Divindade?!

Eu creio no astro onipotente, criador dos dias e das cores.

A epígrafe ou paratexto é de José de Espronceda Y Delgado (1808 - 1842), poeta romântico, autor de Diabo-mundo (1840). A tradução é: “As crenças que abandonas, / Os templos, as religiões / que passaram, e que logo / reconheces como mentira, / são, talvez, menos mentira / que aquelas que agora inventas?”

De todos esses processos, o que mais se baseia nos efeitos da harmonia imitativa, resultantes da combinação dos sons das palavras ao seu conteúdo representativo. Essa combinação trabalha no sentido de reforçar auditivamente a evocação do tema, provocando associações que a sugiram por via sensorial. Isso pode também criar uma atmosfera musical impressionista que traga mais valor expressivo ao conteúdo, por meio de relações que psicologicamente ligam o som das palavras ao significado, produzindo excitações emocionais. Nesta versão em livro, a última parte, referente à intromissão sonora do sino, não aparece. Há 
mudanças na seleção vocabular, na estruturação dos parágrafos e a presença de uma epígrafe, como em sete dos oito textos do corpus, publicados no livro.

\author{
TRANSIT \\ Coeli enarrant gloriam Deiu, et opera \\ magnum ejus annuntiat firmamentum. \\ L. PSALM - XVIII
}

À beira do agreste atalho um túmulo. Os cães visitaram-no; a cruz caiu. Fora da cova, de envolta com a terra, uma caveira parece intencionalmente voltada para o infinito. $\mathrm{O}$ osso recortado da face afeta o riso áspero e impertinente, a ironia fixa de todas as caveiras.

No espaço e na terra, noite fechada, calma absoluta; os astros olham vagamente agitando os cílios de prata. Há um murmúrio vago como a respiração do silêncio. Dir-se-ia ouvir o monólogo meditativo dos seres através da sombra.

\title{
O TÚMULO
}

Das passadas arrogâncias nada encontras no invólucro do osso. Pura lama o cérebro estulto que concebeu dividir em tribos a inumerável vegetação das várzeas e das montanhas, da nome a cada uma das rochas subterrâneas, inquirir o problema permanente das origens!

Perderam-se os efêmeros atrevimentos. A vegetação do solo ubérrimo cresce como sempre, desordenada e festiva; o granito imortal ampara na espádua o teto das cavernas, indiferente à vaidade das teorias.

\section{UMA ESTRELA}

Moravam no crânio os sistemas e os ideais eram como as constelações do céu; cada pensamento era um meteoro relampeando. O cérebro ditava as leis; impunha-nos a geometria tirânica; marcava o índice do futuro; explicava o passado!...

Vão-se os sistemas, apaga-se o astro das idéias, parecem as fórmulas com o cérebro. - Nós, eternas como divindades, vivemos!

Infinito coro longínquo das estrelas findas!

Salve, Século! 
A epígrafe aparece em latim e tem como tradução: “Os céus narram a glória de Deus, e o grande firmamento anuncia suas (Dele) obras”.Refere-se ao salmo XVIII ou XIX conforme a edição bíblica.

Em alguns casos, a combinação de semelhança fonética parcial e a disparidade sêmica (paronomasia) provoca um efeito inusitado, a surpresa ou estranhamento, acentuados pela pausa do travessão Conforme pode ser observado, quase todos os textos reunidos em livro foram acrescidos de uma epígrafe. Esse processo da escrita é visto, sob o prisma da intertextualidade, como resultante do processo de leitura de outros textos ou paratexto.

As diferenças entre o texto jornalístico são semelhantes às dos textos anteriores. Pelo burilamento da canção em prosa, houve alterações na pontuação, no layout, troca de palavras ou expressões e o acréscimo de pequeno parágrafo, com efeito de epílogo: “infinito coro longínquo das estrelas findas!/Salve, Século!”, contribuindo para maior valor estético do texto que se apresenta mais literário, mais lírico.

\section{SOLUÇÃO}

Para que mais, insensato?! Aqui venho eu da grande derrota. Baixei ao fundo dos problemas; visitei, com o verme, as entranhas da terra; com o vendaval, o horizonte; com as sibilas, os astros; com o albatroz, a fúria das tormentas; com o luar pálido, o coração da noite; com a estrela, o infinito; como os sonhos, a nuvem do passado. Deu-me luz o sol, deu-me firmeza o penhasco, deu-me eloqüência o raio, deu-me asas o ciclone, deu-me arrojo o mar! Estudei, indaguei, auscultei, interpelei, evoquei, apostrofei; fui da apóstrofe à maldição, da maldição à blasfêmia. Aurúspice sacrílego, cavei o ventre aos deuses! Sondei, sondei, sondei! Desafiei o gênio negro das metamorfoses; insultei as vertigens do abismo!...

E o gênio negro respondeu-me: - Nunca!

E eu li no abismo: - Nunca!

O texto aparece sem epígrafe. Nesta canção, mais do que em sua versão jornalística, observa-se a repetição de frases exclamativas, além do objetivo lírico e satírico, que permite a introdução de movimentos rápidos, ritmos regulares e cadências poéticas no texto. A “viagem” do texto anterior é substituída por “derrota”. Há alteração na disposição do texto, 
em seu layout, na pontuação e o objetivo de seu burilamento foi alcançado, porque ele apresenta-se mais literário, como convém a uma versão impressa em livro. Não há epígrafe nesta canção sem metro.

\author{
7. TORMENTA E BONANÇA \\ les flots murmurent leur éternel \\ murmure, le vent souffle, les \\ nuages fuient, les 'toiles scintillent, \\ froides et indiferentes - et um fou \\ attend response. \\ H. HEINE - La mer du Norde - \\ Trad. de Gerard de Nerval
}

Tabernáculo abandonado dos velhos deuses! Bradava uma voz na tormenta.

Céu profundo! Morada do terror e do silêncio! De que val a luminária dos astros? É mais tenebroso o teu seio que as insondadas cripas das minhas profundezas. Oceano etéreo, onde os mundos nadam! Que ignotos litorais restringem o teu âmbito incalculável?

Onde vão parar as estranhas ondas e as correntes e os turbilhões que te convulsionam a espessura? Donde despedes o golpe do furacão que lacera as vagas?

Os homens, meus irmãos, desesperam-se comigo e inquirem. Sob a ameaça dos profetas, acobardaram-se, foram pedir pousada aos templos para o seu terror, tentaram propiciar-se pela lisonja.

E a imensidade embebeu o fumo inútil das aras. Aos homens replica o sarcasmo imortal da morte.

Que mão a é esta que trucida os homens, que flagela as vagas? Onde acoutas, ó céu! Esse fantasma adverso que os fere, que me fere?!

Serenou o mar; estendeu-se-lhe à superfície a calma da prostração e a mudez. Flutua-lhe, à tona, a vasta tristeza habitual - decepção perpétua das perpétuas audácias do oceano. 
Temos como autor do paratexto nesta canção, Heinrich Heine (1797-1856), escritor alemão, poeta do dilaceramento e da dor. A princípio foi atraído pelo romantismo em suas primeiras obras. Um amor infeliz fez com que partisse para a França, onde atuou como intermediário cultural entre os dois países, elaborando para os franceses um resumo do pensamento moderno alemão da época (1834) e para o povo alemão, esboços de Paris. Jornalista de talento e considerado pelo unificador Bismarck, como o maior poeta alemão depois de Goethe. Foi banido por Hitler das escolas e bibliotecas.

Além do caráter rítmico e, conseqüentemente, poético que a repetição regular ou paralela dá ao estilo, por meio de suas ressonâncias cadenciadas e musicais, o efeito lírico decorrente do uso desta técnica, procede de sua própria expressividade, independentemente de seus efeitos melódicos. Nesta versão do livro aparece uma epígrafe de Heine (1797-1856), traduzida para o francês "os riachos repetem seu eterno murmúrio, o vento sopra, as nuvens passam, as estrelas cintilam frias e indiferentes - e um tolo espera resposta” (Tradução nossa).

É importante ressaltar que ao longo da leitura das canções de Pompéia, percebemos que o tempo cronológico apresenta-se diluído no tempo mítico e esse aspecto contribui para a expressão da independência da visão de mundo do autor. As alterações são semelhantes às dos textos anteriores. Devido ao seu burilamento, o texto se apresenta mais literário, percebe-se alteração na pontuação, no layout do texto, substituição de algumas palavras.

\section{CONCLUSÃO}

(a Fábula do Céu)

Omnis mundi creatura

Quase líber et pictura

Nobis est, et speculum!

Nostrae vitae, nostrae sortis

Fidele signaculum. 


\section{ALUNUS INSULANUS.}

Serena o mar...

Torna também o firmamento à limpidez da bonança. Ao mar, os homens, reapareceu, sem mácula, a amplidão do azul.

Sem mácula!

Pode vir de novo a coorte dos nimbos travar o drama da tempestade. Pode vir a estrela e prosseguir a jornada nômade que leva!

Venha, prossiga a neve, flameje o astro. Para a nuvem, risonha ou trágica, sombria ou luminosa, pejada de raio ou penetrada de luar, lá está o cenário franco. Para o astro, impossível, la está o rumo das órbitas desimpedido!

Estrela, nuvem - nuvem que passa, estrela que arde.

Sobre o céu eterno destaca-se bem a antítese destas criações diversamente efêmeras do Mistério. Supremo ensino das cousas!

Em vivo contraste, sobre o fundo obscuro do tempo intérmino - a nulidade real dos múltiplos aspectos combinantes das existências.

O céu, como uma a fábula, tem esta moralidade.

A tradução da epígrafe em latim é: “Toda criatura do mundo / é para nós como um livro, (e) / uma pintura e um espelho / É imagem fiel / de nossa vida, de nossa sorte [destino]”.

Por meio do uso da repetição, percebemos que as palavras simples podem trazer bastante carga poética, tornando-se focos de irradiação lírica ou instrumentos de poetização do estilo. Esta versão em livro do texto jornalístico apresenta conteúdo semelhante, mas com traços de burilamento do autor, a exemplo dos anteriores. Este texto traz um subtítulo - A fábula do céu e uma epígrafe em Latim que poderia exercer a função antecipadora de um mise-en-abyme, em texto narrativo, por trazer em síntese as idéias desse poema em prosa, “Conclusão”, a meu ver, o mais belo entre os selecionados como corpus. Pois, instala-se uma ordem em que os signos simbólicos formam uma espécie de constelações de imagens que vão criar uma atmosfera interior em síntese altamente simbólica e metafórica, conforme podemos perceber na leitura crítica dos poemas em prosa de Pompéia. Nessa tendência lírica expressa por meio de imagens 
nucleares percebe-se o caráter cíclico das composições, em que são retomados os motivos iniciais como desfecho. Também a forma alegórica que as canções trazem oferece ao leitor as possibilidades de movimentação subjetiva. Certa tonalidade moralizante, realizada sob a forma de aforismos, acrescenta-lhes um aspecto de intemporalidade, às vezes marcado pela ironia originária de um pensamento social. Aqui, nesta versão do livro, em dialogismo intratextual com o texto original do periódico de suas Canções sem metro, ele troca "resistir" por "triunfar", o tempo passado pelo presente, “serenou o mar...” “por serena o mar...”, fazendo pequenas alterações na pontuação, no layout. O resultado é um texto ainda mais lírico e literário.

A organicidade das Canções sem metro decorre de uma estrutura que incorpora momentos: 1. uma impressão inicial, definidora da percepção da realidade, que corresponde à presença ontológica-estética do poeta; 2. o oxímoro do amor (ou do desejo), debruçamento inicial sobre o “outro”, definidor da forma estética (ou seja, da comunicação estética);3. a gênese da realidade, espelhada no processo de criação do poema; 4. o espírito que anima a realidade e a constatação de que o ato criador produz apenas palavras; 5. o assentamento desta realidade contra o fundo do tempo e o reconhecimento da "nulidade" final. Todos estes elementos são traduzidos por um sistema binário e contraditório, como já o denunciou Ivo (1963), repetição ad infinitum, do oxímoro titular.

Vejamos, com maior cuidado, estes cinco momentos.A primeira secção divide-se em onze segmentos interligados, uma tentativa de descrição do fenômeno vital como uma "vibração”. Esta vibração emocional provoca a impressão da cor, traduzindo-a na realidade. A imagem é totalmente romântica: a "harpa do sentimento", que lembra as várias "harpas eólias" que encheram a literatura do romantismo, é uma recriação da metáfora da "brisa correspondente", ou seja, da movimentação do ar como respiração do universo e todas as suas decorrências, do micro ao macrocosmo Essa vibração produz duas imagens contraditórias e complementares: uma externa, que corresponde à cor (verde, amarelo, azul, roxo, vermelho, branco, negro, rosa, incolor e indistinto) e outra externa, que corresponde ao sentimento (ímpeto, contemplação, isolamento, pranto, grito, êxtase ou letargia, frieza, sonho, tédio, revolta).

Os segmentos que compõem esta primeira parte não requerem uma seqüência absoluta, embora haja certa gradação à qual o respeito à ordenação dada pelo autor dá ênfase. Pode-se, por exemplo, dizer que há um ímpeto inicial e que o término das vibrações é a indistinta 
revolta do escravo que odeia os dois grandes símbolos que oprimem: a igreja e a civilização (representada pelo trem de ferro, que é a metáfora do progresso comum no período), já em passagem para a área da ação, a ser tratada na quarta secção da obra. Na área puramente estética, estes fragmentos representam uma definição do impressionismo como atitude estética do poeta, ou seja, o princípio de que toda percepção estética, para Raul Pompéia, é a impressão. Esta mesma formulação estética é reconhecida pelos críticos que tratam de outras obras do autor, principalmente de $O$ ateneu.

A segunda secção das Canções sem metro apresenta apenas cinco segmentos, e nela o oxímoro é resolvido como circularidade das estações, círculo no qual qualquer ponto atingido terá sempre seu oposto. Assim sendo, o inverno é visto literalmente como saudade da primavera; a primavera, metaforicamente, como uma escrava que liberta uma ave prisioneira; o verão, já num ponto mais avançado de abstração, como a vivência da "intensidade mortal da vida”; e o outono, de volta à concreção metafórica, como o fruto morto que nutre a vida das sementes. E, fechando o círculo conceitual, o que há é uma "universal comédia das formas”. A ação de “amar”, que dá título à secção, é apenas uma “ilusão renitente”, um "sentimento” que sobrevive ao cataclisma, uma “concentração espiritual”, a "luz de um olhar”, ou seja, a descoberta da presença do outro. A forma estética evidenciada nesta secção resolve-se pelo desejo de comunicar a impressão inicial, um segundo estádio de desenvolvimento no qual a vibração inicial pode ser transmitida além do centro de sua aparição. Como as estações que se resolvem como oxímoros, pontos contraditórios num círculo fechado, a impressão existe também no círculo da percepção, enfrentando sempre um “outro” que permite sua transmissão, sua comunicação. A impressão percebida através da vibração, que aparecera na primeira secção, pode ser comunicada através da ação de “amar”, que é apenas uma paralela percepção do “outro” como “um simples clarão”.

A terceira secção, “O Ventre”, trata da gênese da realidade. Os quatro segmentos iniciais “O Mar”, “A Floresta”, “Os Animais”, “Os Minerais” descrevem, numa gradação bíblica, a realidade natural em que se insere a impressão e sua possível comunicação, ou seja, o seu contexto. Esta natureza é descrita em termos contraditórios, dentro da estrutura geral do livro: o mar como princípio criador, destruidor e cúmplice; o mundo vegetal como animal; os animais como transmissores de qualidades negativas ao anjo que por isso se faz homem; os 
minerais como materiais de criação satânica. Estes quatro segmentos iniciais seguem, simetricamente, os passos iniciais do Gênese bíblico, fechando-se com a consideração de que a civilização (metaforicamente apresentada como a mineração) e trabalho demoníaco. Nisto, Raul Pompéia coincide como os intérpretes bíblicos que vêem em Caim o pai da civilização.

Os segmentos seguintes desta terceira secção concluem o Gênese: em "Indústria”, os homens dominam o mundo pelo emprego de processos criados pela civilização; em “Comércio”, o mundo é transformado em dinheiro, isto é, em símbolo; e, em “O Ventre”, há o equilíbrio e a contradição entre o centro e o que gira a sua volta (o mundo como História). Nesta máquina do mundo, criada por Raul Pompéia, há uma percepção de que no centro da criação encontra-se um elemento que foge às avaliações de Bem e Mal, contraditoriamente equilibrado na sua autodestruição e auto-recriação, e que ai “preside e engorda”. O locus em que se dão estes acontecimentos é a noite, “que nos revela a sub-natureza dos homens e o espetáculo incomparável das estrelas”. Paralelamente, o oxímoro de criação e destruição que aparece nesta parte das Canções sem metro, lembra o Humanitas de Machado de Assis, e, esteticamente, a gênese da criação artística. Resumindo até aqui: a impressão inicial que se quer comunicar forja-se na natureza e na civilização, consideradas como forças opostas, e resolve-se como um desejo dirigido a duas coordenadas “o espetáculo incomparável das estrelas” que a noite primeva oferece.

A quarta secção, “As Vaidades”, abre-se com a descrição do que do que a realidade diz ao homem para seduzi-lo. Estes elementos traduzem-se na constatação da embriaguez da beleza “A Arte”, do conhecimento "Mefistófeles”, do amor que é também forma de morte “História de amor”, da ação política "Revoluções”. Continua o ímpeto do desejo da aurora futura "Esperança” que sucederá à noite da ignorância "Veritas”. Nesta caminhada continua, surgem à frente apenas as pirâmides, representativas da contradição entre a permanência que é o monumento e a destruição que é o túmulo “Deserto”. No fim, tudo são palavras "Hamlet”. Assim sendo, a impressão que se quer comunicar e se forja na natureza e na civilização, perceptível como um desejo de superação objetivado num espetáculo estelar, reduz-se, no fim de tudo, a um amontoado de palavras.

Colocada a perspectiva contra o fundo do infinito, na quinta secção das Canções sem Metro o poeta percebe que há uma eloqüência maior que o rumor destas palavras "Rumor e 
Silêncio", esse rumor inclui o passado "Ontem”, o presente em que o futuro "espera como fera" "Hoje” e a realidade do desaparecimento deste mesmo presente "Vulcão Extinto". Não só a História, mas a materialidade também espera sua destruição “Os Continentes” e até mesmo o princípio de tudo “Os Deuses”. Metáfora desta destruição final que espera tudo são os túmulos, ante os quais só permanecem as estrelas, símbolo do infinito "Transit”. O fracasso final do pensamento humano "Solução" atinge a natureza “Tormenta e Bonança” e tudo é nulo contra o fundo do tempo “Conclusão”. No espelhamento do poema, o amontoado de palavras a que fora reduzida a impressão comunicada através do desejo de “eternidade” (as estrelas), face ao infinito, é também nulo.

Todo o processo de criação, em todas as suas facetas e perspectivas, é uma contradição, um oxímoro que se resolve apenas como um desejo de criação contra a nulidade infinita. Assim como a realidade é, na metáfora de Machado de Assis, uma bolha que desfaz em eterna repetição, a criação artística também é reduzida à contradição do inútil desejo de perenidade, oxímoro que leva a nada ao fim. De uma maneira mais simplificada, o antagonismo entre prosa e poesia, da nomenclatura genérica baudelairiana, presente na idéia de canção a que falta métrica (ritmo), só se resolve pela constatação final da nulidade de ambos: tese e antítese, em vez de síntese, produzem o nada. “O céu, como uma fábula, tem essa moralidade” eis o fechamento que Raul Pompéia dá às Canções sem metro.

Esta leitura minuciosa a que foi submetida a obra demonstra o esforço do poeta em sua criação: se $O$ ateneu é produto febril de um trabalho aturado no espaço de uns poucos meses, as Canções sem metro são verdadeiramente o trabalho de cerca de 12 anos. É possível que Raul Pompéia não considerasse a obra como terminada quando de sua parte, a despeito da expressão “forma definitiva” que aparece como rosto do manuscrito usado para a edição póstuma de 1900. De qualquer maneira, esta expressão obriga-nos a aceitar que o livro estava pronto para a imprensa e seria definitivo naquele momento, como toda obra de autor vivo é definitiva ao ser publicada. $\mathrm{O}$ aspecto póstumo não deve, portanto, ter qualquer influência em nossas considerações: o livro é um conjunto orgânico e foi terminado por seu autor na forma que encontramos. 
Percebemos que o campo das idéias da prosa poética de Pompéia oscila entre a arte e a ciência, que constituem o cerne da cosmologia em as Canções sem metro. De certa maneira, o campo destas idéias. Na antiga área das impressões, os limites entre arte e ciência se dissolvem e a linguagem da racionalidade começa a soar como a da imaginação.

Então, o pessimismo cantado pelo eu poético em Pompéia pressupõe que tudo ao fim tem o sentido da frustração que espera todas as cosmologias. Hesíodo podia escrever uma cosmogonia, a visão de um mundo pré-científico, cujo remate e explicação se encontram na presença divina: Raul Pompéia, escrevendo uma Cosmologia, só vê o enfrentamento final com um infinito ininteligível. A frustração geral é do ser humano, não específica do poeta. Como sua contribuição fica o poema em prosa, marco literário no Brasil, semelhante às pirâmides no deserto, os “animadores túmulos”, são apenas um oxímoro, que é a derradeira moralidade que se pode extrair do todo.

Embora vários críticos apontem como fonte das correspondências a leitura de Baudelaire e dos simbolistas, tal influência na obra de Raul Pompéia apresenta-se contraditória, haja vista a ausência do misticismo, que há na filosofia de Swedenborg, em sua visão de mundo. Tal idéia também pode estar ligada às raízes, tanto das teorias da física óptica, vigentes no final do século XIX, como da teoria das cores de Goethe. Aliás, a hipótese da confluência entre a teoria mística de Swedenborg e a teoria científica das vibrações já foi levantada por Sônia Brayner (1979, p. 234), que considera a presença de ambas no discurso do professor Cláudio, personagem de $O$ ateneu.

Todavia, pode-se concluir que, em temperamentos de gênios literários, à semelhança de Põe e Pompéia, existe um poder de conduzir e explorar arbitrariamente uma espécie de espírito subterrâneo ou inconsciente, ou seja, a capacidade de agitar os mais obscuros problemas, para dar-lhes um colorido nunca conseguido, no estado normal da inteligência.

Segundo o crítico Heitor Martins, em artigo publicado no jornal - O Estado de São Paulo, em 19 jun.1990, resumindo as citações de dois dos principais críticos da obra de Pompéia - Ledo Ivo e Afrânio Coutinho -, percebe-se que a obra Canções sem metro é vista como obra de importância, contudo malograda. Atribuem seu esquecimento à injustiça da 
critica que dá relevância às obras a partir do movimento modernista de 1922. Ainda ao ofuscamento provocado pelo sucesso estrondoso de seu romance $O$ ateneu.

Pelo fato de discordarmos do pretenso malogro das Canções sem metro, título de artigo escrito por Ivo (1963), citamos Martins (1990), que defende a teoria de que Pompéia integra o projeto literário brasileiro que se inicia com os neoclássicos, atravessando a experiência romântica e o período do realismo burguês, apresentando certas características básicas do movimento literário: a tradição portuguesa, sobretudo, em se tratando de uma língua nacional, com raízes coloniais, a inclusão das minorias culturais, como a africana e a indígena, participantes e complacentes com o domínio da tradição portuguesa. Ainda, a consciência de que a realização desse projeto se concretiza em solo americano, com a criação de uma literatura que apresente o instinto de nacionalidade a que Machado de Assis se referia.

O chamado espírito de modernidade, tanto em nível ideológico, como estético que se sobressai desde o romantismo, não invalida esse projeto literário, mas afirma a necessidade de progredir, avançar, desenvolver-se, transformar, mesmo porque é impossível cortar as influências de estilos anteriores.

O escritor Raul Pompéia vai além pelo fato de levar para a tradição do então vigente projeto literário brasileiro suas novas formulações estéticas que a modernidade viria ainda impor. Ressalto que, de certa forma, a invasão futurista de 1922, provoca uma implosão nesse projeto literário, mencionado por Martins (1990), substituindo-o pela importação de vanguardas, ou seja, a modernidade deixa de ser produto do progresso local para assemelhar-se ao progresso alheio. Neste ponto, Pompéia foi realmente original, criando um gênero novo e nacional.

A intervenção estética e a recepção dos poemas em prosa de Pompéia têm sido prejudicadas pela opção de uma leitura de caráter existencial e niilista, em detrimento de outra leitura picturial, metafísica e apolínea. Como já o dissemos, um de seus melhores leitores críticos foi Ivo (1969), que conseguiu penetrar mais profundamente em sua leitura realizando um mergulho estético na poética pompeiana. Mas é importante lembrar que a prosa poética de Pompéia se assemelha muitas vezes a instantâneos fotográficos, pequenas pinturas de fatos, situações ou personagens, a fixação do efêmero, de acordo com a técnica da teoria do impressionismo, já citada. 
Portanto, mais uma vez ressaltamos a idéia original do poeta e sua peculiar inclinação às artes visuais. Sua escritura-imagem cria mundos cosmogônicos condizentes com a busca metafísica do escritor, às vezes despertando no leitor a sensação de embriaguez ante a percepção de um outro mundo que de certo modo supera o mundo real e satisfaz o nosso anseio de ir além da realidade. Então, a sua prosa poética mostra-nos exatamente este processo de captura perceptiva da realidade na forma de iluminuras.

Finalizando a comparação intratextual entre as versões correspondentes, impressas em jornal e, posteriormente, em livro, haja vista que este estudo está ligado à imprensa e ficção do século XIX, percebemos que o processo de concepção de mundo e o processo de evolução literária do próprio autor estão explícitos nas técnicas de composição das canções, que aparecem na forma inovadora de prosa poética ligada à linguagem jornalística, por meio do ponto de vista. E voltando ao conceito de gênero do discurso defendido por Bahktin (1987), se existe estilo, existe gênero, com a definição de estilo de Da Cal (1969) e a teoria da prosa poética de Morier (1981), podemos afirmar que Pompéia trabalhou e construiu uma forma híbrida - a prosa poética - constante de suas Canções sem metro desenvolvidas nos periódicos do século XIX. O valor dessas composições tem sido incompreendido até agora, mas merece um resgate junto à crítica. 


\section{CONCLUSÃO}

Percebemos ao longo da pesquisa que os textos apresentados, sob a forma de prosapoética, trazem poeticidade ao jornalismo literário, com conotações de crônicas dos periódicos da época, apesar de constituírem um conjunto orgânico, planejado cuidadosamente por Pompéia, de valor literário ainda incompreendido pela crítica.

Seu questionamento metafísico é profundo, mas vislumbramos também a presença de vertentes sociais. Concordamos com a crítica no que diz respeito ao fato de sua prosa poética se estruturar a partir de uma tensão entre o mundo exterior, com suas imagens visuais e o interior com as imagens metafísicas, mas prenhe de questionamentos intimistas. Há, seguramente, em sua obra uma recorrência às imagens impressionistas. E a seleção vocabular e a forma dos seus poemas em prosa aparecem reformuladas, em diferentes edições, o que comprova um componente biográfico importante: a prosa poética para Raul Pompéia foi um exercício de disciplina, em que o autor perseguiu obsessivamente a perfeição. Este fato explica as várias formas trabalhadas de um mesmo texto e publicadas em épocas e periódicos diferentes.

Em relação aos textos do corpus selecionado para estudo, primeiramente publicados em A Gazeta de Tarde, no período de 21 a 29 de janeiro de 1886, mas, posteriormente constantes da quinta parte do livro Canções sem metro, intitulada - Infinito -, vimos que sua cosmologia mítica agiliza o despertar de uma consciência mais profunda da vida humana. Desde a antiguidade, temas míticos ligados à existência humana têm contribuído para a construção de civilizações e a formação de religiões ao longo dos milênios e se mantêm relacionados aos problemas internos do ser humano. Se o ser humano não reconhecer os sinais ao longo do caminho, possivelmente, terá que descobrir tudo sozinho, portanto essa abordagem dá dinamicidade à sua evolução. Assim como as Canções sem metro de Pompéia, os mitos são os relatos da busca, feita através do tempo, do significado e do sentido da vida para tocar a eternidade e entender o desconhecido, para descobrir quem somos. Todo ser humano busca o sentido para a sua vida, ou seja, busca a experiência de se sentir vivo, por meio das experiências físicas e de seu sentido interior. Pompéia o faz por meio da construção das suas Canções sem metro, criando ao mesmo tempo um novo gênero no ambiente jornalístico. 
Sabemos que as estruturas simbólicas das Canções sem metro não são aleatórias, tampouco, foram utilizadas para descrever a realidade percebida por Pompéia, apesar de o símbolo constituir a melhor maneira de apreensão do cosmo. Pois, o símbolo não é arbitrário e reflete autenticamente o que expressa. Sem a sua presença seria impossível qualquer relação ou comunicação. No corpus estudado, podemos citar uma metáfora da mencionada destruição final que tudo espera: são os túmulos, ante os quais só permanecem as estrelas, símbolos do infinito que aparecem em "Transit”. O fracasso final do pensamento humano é a "Solução" ainda sem solução que atinge a natureza apresentada como: “Tormenta e Bonança” e tudo é nulo contra o fundo do tempo - a "Conclusão". No espelhamento do poema, o amontoado de palavras a que foi reduzida a impressão comunicada por meio do desejo de eternidade simbolizado pelas estrelas -, face ao infinito -, é também nulo. Como percebemos, a busca de uma cosmogonia tem relevância em todos os textos contemplados.

Por outro lado, seu questionamento metafísico, às vezes, contraditório, mas constante em sua prosa poética composta junto ao jornalismo é válido para todo tempo e lugar, na dimensão do humano. Aliás, como já foi observado, o estilo de Pompéia e sua criação inovadora refletem a sua visão de mundo. Na verdade, o questionar do eu poético em Pompéia constitui um símbolo de algo muito mais amplo que o transcende, já que pode ser concebido e explicado, como uma modalidade arquetípica do universal.

Durante o percurso desta pesquisa concluímos que a trajetória literária de Raul Pompéia foi realmente a busca de um novo gênero poético, livre dos movimentos literários anteriores. E, certamente, as contradições de sua sensibilidade artística não poderiam deixar de ser expressas, advindo, então, um conjunto orgânico de questionamento do cosmo, a busca de uma cosmogonia reiterada em todos seus textos de prosa poética, publicados nos periódicos do século XIX, em que ele exercitou e aprimorou a sua linguagem literária. A importância do tema pesquisado reside no fato de haver pouca crítica relativa às Canções sem metro junto à conseqüente falta de reconhecimento de seu valor na literatura brasileira. Assim, a pesquisa dirigiu-se no sentido de procurar ver como se deu a criação da prosa poética de Pompéia, gênero híbrido e inovador exercitado junto ao jornalismo literário e o porquê de seu pouco reconhecimento pela recepção crítica até a atualidade. Buscou-se, portanto, entender sua prosa poética e procurar demonstrar sua importância inovadora, atentando para um maior 
reconhecimento de seu valor, além de ressaltar a importância do uso simultâneo de duas linguagens artísticas, dentro de suas técnicas de composição, ligadas à imprensa e à ficção.

Por exemplo, o uso do visual no texto verbal, incluindo textos publicados com imagens ilustradas pelo autor, na revista A Galeria Ilustrada (1888-1889), nesta pesquisa interdisciplinar ligada ao jornalismo e à literatura do século XIX. Daí, a importância da inclusão dos dez textos ilustrados, publicados na mencionada revista. Uma vez que o objetivo da pesquisa foi primordialmente a criação de um novo gênero, optamos por contribuir com o acesso a esse material de raro ineditismo para os estudiosos da letras nos dias de hoje, o que pode gerar novas pesquisas.

E, finalmente, foi nosso intuito observar a prosa poética de Pompéia em periódicos do século XIX, como um fenômeno de ciência cognitiva, verificando nos elementos de literariedade das escrituras textuais, especificamente, as suas dimensões inovadoras, tendo em vista a criação de um novo gênero híbrido - a prosa poética de Pompéia -, desenvolvida em ambiente jornalístico no final do século XIX. Por isso, priorizamos a análise da versão selecionada do periódico, dialogando intratextualmente com os textos correspondentes. Isto se justifica também pelo fato de as Canções sem metro ainda não apresentarem uma versão completa em livro, uma vez que elas foram compiladas parcialmente, nas três edições das quais as canções foram objeto, desde 1900. Há uma pesquisa em andamento, nesse sentido, que está sendo realizada por Eduardo Coutinho.

De qualquer modo, a produção das canções é de grande mérito literário, e só se explica a sua pouca repercussão pelo fato de que o êxito de $O$ ateneu a tenha ofuscado, colocando-a à margem. Também o chamado modernismo de 22 que colocou em segundo plano a brasilidade. Vista por uma perspectiva moderna e relacionada ao contexto universal, a criação desse gênero no Brasil deve ser considerada de alto valor e importância se observada por uma perspectiva moderna e relacionada ao contexto universal. Afinal, ela constitui legítima expressão brasileira de um gênero original que merece reabilitação crítica, pois abriu caminho para uma renovação da literatura brasileira, tal como ocorreu na França, onde a poesia recebeu do gênero um saudável e definitivo impulso modernizador. Infelizmente, ao contrário do que ocorreu na França, as correntes modernistas brasileiras não prestaram atenção às canções de Pompéia, talvez pela pouca divulgação que tinham e certamente pelo comportamento 
inadequado dos chamados futuristas, inimigos de tudo o que existiu antes deles. A crítica de Mario de Andrade pode exemplificar essa falta de incompreensão da crítica literária. Entretanto, as conquistas de um espaço subjetivo mais amplo foram importantes para os destinos da ficção e da modernidade brasileira e essa contribuição foi trazida com a composição inovadora de Pompéia. Desde o início da concepção da prosa poética, com seus textos microscópicos, Raul Pompéia já apresentava, sob a influência das características impressionistas, a preocupação de aliar harmoniosamente o representativo e o subjetivo.A prosa poética caracteriza-se pela estética do fragmento e constitui a desmistificação do poético em intensa rede intertextual, como se percebe com a presença de várias artes. Creio que a produção de um poeta implica uma espécie de incursão consciente ao nível simbólico. Mas há aqueles que compartilham essa criação literária com a reflexão filosófica ou a presença de outros campos da arte, como o autor em estudo.

Como vimos vários críticos têm apresentado as afinidades entre Pompéia e Baudelaire e citam como elementos de afinidade entre os dois poetas: a opção pelo desenvolvimento do poema em prosa, a preferência pelo uso das analogias, o pessimismo, as correspondências, o nirvanismo, demonstrando a influência de Baudelaire na poética de Pompéia. A temática da destruição dos ideais e a sua dramatização na linguagem são também aspectos comuns aos dois escritores. Naturalmente pelo fato de Baudelaire haver traduzido Poe e levado seus princípios de composição literária para a Europa, podemos perceber que nesses autores foi a fonte inspiradora que veio coadunar com suas preferências literárias que se encontravam em estado ainda latente. É a questão da confluência literária, em vez de influência, como explicitado antes. Poe define a poesia como uma criação rítmica da beleza, ou seja, “a poesia é a meta de toda arte superior e o único meio de atingir o belo”, Baudelaire (2002). Pompéia compartilha com Baudelaire, o chamado poeta da modernidade, a capacidade de ver no deserto da metrópole não só a decadência do homem, mas também de pressentir uma beleza misteriosa, não descoberta até então. Pompéia, assim como Baudelaire, jamais tiveram pressa em publicar seus poemas que foram escritos, reescritos, alguns provavelmente destruídos, fundidos, refundidos e burilados cuidadosamente por muitos anos.

Mas como nossa preocupação principal está ligada à construção de um gênero inovador no Brasil, a prosa poética das canções de Pompéia ligadas ao jornalismo e à literatura, 
chamamos a atenção para aspectos semelhantes entre os textos dos poetas da modernidade, na França e no Brasil, especificamente, Baudelaire e Pompéia. Seus textos são considerados prosa poética porque o ser de enunciação em cada um deles faz uso do poder sugestivo da linguagem, por meio de analogias e correspondências, entre sons, cores, perfumes e símbolos, apresentando característica de brevidade, de quase ausência de diegese e estilização da linguagem. Além disso, a temática, o uso da ironia e a construção que prioriza a criação de um efeito final e de uma epifania constituem aspectos comuns aos dois autores, justificando a comparação entre Baudelaire e Pompéia, assim como o próprio Baudelaire manteve semelhante prática intertextual com Poe, devido a uma comunhão conceitual entre ambos. Para eles a poesia é a meta de toda arte superior e o único meio de atingir o belo. Baudelaire e Pompéia evidenciam a noção de queda, a angústia do abismo. Baudelaire esteve próximo do conceito de uma arte total em que a palavra, a cor e o som, graças a um difuso sistema de analogias, nos sugerem esse infinito sonho do espaço e profundidade em que consiste a suprema epifania da beleza.Ambos dialogaram com as dúvidas do século e descreram em dogmas e tradições.

Repetimos que Baudelaire, como produto de sua época, herdou do romantismo as contradições inconciliáveis, as tensões espirituais cujos pólos antitéticos nunca lograram atingir a síntese hegeliana. O absoluto e o infinito pelos quais o poeta ansiou ao longo de sua existência lhe foram impossibilitados pela sua sempre presente visão de queda, também compartilhada por Pompéia.

Constatamos que na prosa poética das canções de Pompéia há freqüência de nomes abstratos e de temas metafísicos ligados à cosmologia, há alianças incomuns na formação de sintagmas provocando estranhamento e contribuindo sonora e inovadoramente para maior expressividade retórica. Também, a seleção vocabular e a sintática servem como elemento rítmico no texto. A inovação na ordem das palavras e na pontuação também é bastante expressiva. As percepções são duais devido à utilização de antíteses constantes. As enumerações relativas a uma espécie de viagem mítica do ser de enunciação nas canções de prosa poética atuam como elementos de musicalidade no poema, os verbos repetidos ou enumerados têm função rítmica e musical. As frases curtas e a pontuação também contribuem para a expressividade retórica dos poemas em prosa poética, sugerindo ao mesmo tempo muito 
movimento, ações inúteis, para uma busca sem solução. E todos estes recursos estilísticos comprovam a forma inovadora de grande valor literário criada por Pompéia.

Como vimos, Baudelaire e Pompéia traziam o crítico dentro de si mesmos e anteciparam não apenas os temas da modernidade, mas todo o processo estético da poesia moderna. Com o retorno da lírica à sua essência e a ligação da arte literária à música, a poesia volta a ser, como na época dos gregos, uma manifestação divina, um êxtase da alma. Mas essa alma é humana, portanto filha da tensão e da contradição, afirma Ivan Junqueira (apud BAUDELAIRE, 2002, p.81). Ele deu especial atenção à brevidade do texto, insistindo que tudo o que ultrapasse a duração da atenção que o ser humano pode prestar à forma poética não constitui um poema. Esse poeta, sobretudo, conferiu todo o sentimento metafísico que faltava à poesia musical e, muitas vezes, vazia, de Poe.

Foi ainda Baudelaire aquele que concretizou o sonho de libertar o verso de todos os elementos narrativos e didáticos que até então o poluíam, lançando na França, a exemplo de Pompéia no Brasil, os fundamentos da poesia moderna, de acordo com exemplificação no terceiro capítulo. A temática da queda, compartilhada por Baudelaire e Pompéia remete ao abismo que está ligado ao caos do pensamento grego. Intimamente relacionada ao tema do abismo está a ânsia do infinito, também percebida em ambos escritores. E novamente a busca de infinito nos leva à queda, que em Baudelaire significa ao expurgo do éden terrestre. Todavia, o infinito em ambos apresenta-se finito, pois quase sempre leva à dissolução desesperançada. Há uma idéia de supranaturalismo percebida em Baudelaire e Pompéia. Ou seja, a morte constitui-se apenas de um acidente da queda que detém a carga semântica mais pesada. Essa influência parece vir dos mestres Poe e Swedenborg, para os quais a alma não corroída pela morte, leva uma existência fetal, até que o corpo seja totalmente destruído (BAUDELAIRE, 2002, p. 88). Então a alma volta à sua autonomia, liberta.

Para Bakhtin (1997) gênero está relacionado ao movimento. Embora os gêneros representem os modos de organização mais estáveis, certos enunciados ou formas padrão dentro de determinado contexto de comunicação -, ou seja, todo gênero está em constante transformação, em virtude das possibilidades de dialogismo ou contaminação dos próprios gêneros entre si. O gênero é novo e velho ao mesmo tempo, os seja, renasce e se renova a cada manifestação individual, segundo aquele teórico. Todo gênero literário surge de outros 
gêneros, e como diz Todorov (1967), cada gênero é o resultado de uma contínua regeneração. Esse conceito é de fundamental importância nesta pesquisa pelo fato de enfocar a criação de uma forma híbrida.

Devemos atentar para o fato de que a abordagem do jornalismo junto à literatura em trabalhos de pesquisa científica tem sido pouco explorada. Embora a bibliografia sobre o autor seja numerosa, nota-se uma escassa freqüência da crítica da historiografia literária, no tocante ao enfoque transdisciplinar aqui proposto. Tudo isso, dentro da visão da cultura e do texto literário como sistemas modelizantes secundários Bahktin (1987), além de possibilitar um redimensionamento do lugar dos aspectos apontados na poética de Raul Pompéia. Portanto, esta pesquisa possibilita uma rediscussão do impacto dos meios de grande difusão cultural no discurso literário ficcional, assim como a percepção e o registro dos seus aspectos comunicativos, dando relevância à sua prosa poética ligada à linguagem jornalística.

Reiteramos que a produção ficcional para publicação em periódicos constitui uma área deveras interessante, no tocante ao estudo da problemática da criação literária. Sobretudo, no século XIX, uma vez que, naquela época, o escritor era obrigado a realizar um trabalho ainda muito artesanal para uma posterior publicação em forma de livro. Além disso, devemos nos lembrar que a indústria cultural pode levar o escritor a produzir, de acordo com a demanda do mercado, apesar de as estatísticas comprovarem que muitas obras que se tornaram clássicas, devido ao seu alto valor literário, foram, primeiramente, publicadas em periódicos.

A poética de Pompéia esteve sempre aliada à imprensa, como cronista, autor de romance folhetim, além das Canções sem metro que foram realmente sua obra prima. Todos seus textos apresentam qualidades inatas dos grandes escritores ou jornalistas. Grande espírito de observação, visão clara das coisas; excelente reflexão, na análise dos fatos; objetividade, devido a sua mentalidade científica, mesmo com o subjetivismo do poeta, capacidade de exposição detalhada do mundo. Suas canções apresentam unidade, do princípio ao fim, de acordo com sua visão de mundo que implicava a busca de uma cosmologia. E as Canções sem metro, de Pompéia, demonstram claramente que o seu autor consegue incorporar num plano estético, dentro do projeto literário que integra, os problemas por que a modernidade passa. É consenso de toda a crítica que em sua busca obsessiva pela perfeição, apesar de sua curta existência, a poética de Raul Pompéia antecipou as mudanças que ocorreriam em movimentos 
literários de décadas posteriores. Assim, em meio a tantas e ótimas produções, destaca-se um poeta que veio, desde 1881, com seus primeiros textos, publicados em periódicos do século XIX, construir, conforme pudemos comprovar, um dos projetos mais originais e fecundos da poética brasileira de seu tempo que, devido às suas características, estarão sempre contextualizadas. O autor já afirmava: “a arte é primeiramente espontânea, depois intencional”. Pompéia tinha um projeto em construção e sabia o que estava compondo.

Foi possível comprovar, pelo estudo de seus textos, que Pompéia quis fazer uma obra orgânica que representasse uma visão totalizante do universo, lírica e filosófica ao mesmo tempo, do ponto de vista do homem pessimista do final do século XIX. Então, o homem se encontrava descrente das conquistas científicas e sentia-se perdido diante do imenso abismo de interrogações que o desafiavam. Pompéia quis desenvolver o gênero inovador, a exemplo de outros expoentes na Europa, trabalhou árdua e persistentemente e o conseguiu. Sua produção ficcional destinava-se, sobretudo, à publicação na imprensa periódica do século XIX, uma vez que o autor sempre se dedicou ao jornalismo, apesar de bacharel em direito.

Vimos que seu estilo demonstra a sua cosmovisão, conforme podemos observar pela análise de sua prosa poética, pelo cuidado tão bem sucedido com que a construiu. Todavia, lembramos que Pompéia foi um mitólogo e sua visão de mundo, expressa em seu estilo, contemplou a gênese cristã, nos paratextos de suas epígrafes, rendeu culto à natureza, como um panteísta, descrevendo sua ação ou tecendo uma ode ao sol, assim como a temática constante das canções que descreve uma cosmologia, da mesma forma que os mitos buscam explicar o significado da origem do mundo e de seus modos de existência. Acreditamos que as Canções sem metro constituem uma espécie de mito cosmogônico, de acordo com o conceito de Eliade (1986). A diversidade e a riqueza da prosa poética de Raul Pompéia abrem perspectiva para uma gama de novas pesquisas. Apesar de a crítica atual ter investido muito pouco nesta abrangência, esperamos que ainda buscará compreendê-la e explicar a riqueza que a distingue. 


\section{REFERÊNCIAS}

A GALERIA ILUSTRADA, 1888/1889. Curitiba: Imprensa Oficial, 1979. fac-similar.

A GAZETA DA TARDE. Canções sem metro. Rio de Janeiro, 08, 21, 22, 25, 27, 28, 29 jan. 1886.

AGUIAR E SILVA, Vítor Manuel de. Teoria e metodologia literárias. Lisboa: Universidade Aberta, 1990.

, Vitor Manuel de. Teoria da literatura. 4. ed. Coimbra: [s.n.], 1975.

, Vitor Manuel. Competência lingüística e competência literária. Coimbra: Almedina, 1977.

ANDRADE, Oswald de. Dois emancipados. In: O romance brasileiro de 1752 a 1930. Rio de Janeiro: M. Fontes, 1952.

ARARIPE JÚNIOR. Obra crítica Rio de Janeiro: Rui Barbosa, 1960. V. II.

ARAÚJO, Regina Lúcia de. O discurso nelsonrodrigueano em O casamento. Fragmentos de Cultura, Goiânia, v. 10, n.1, p. 181-196, jan./fev. 2000.

. O universo poético nas Elegias Cósmicas de Luiz Palacin. Fragmentos de Cultura, Goiânia, v. 14, n.12, p.2.223-2.242, dez. 2004.

Texto e imagem em Raul Pompéia. Estudos, Goiânia, v.32, n.6, jan. 2005.

ARBEX, Márcia. Le procédé du collage dans l'œuvre de Max Ernst. Caligrama, Belo Horizonte, Departamento de Letras Românicas/FALE/UFMG, v.3, 1998.

BAKHTIN, Mikhail. Estética da criação verbal. São Paulo: M. Fontes, 1997.

. Esthétique et theorie du roman. Tradução de Daria Olivier. Paris: Gallimard, 1987.

- Questões de literatura e de estética. Tradução de Aurora Fornoni Bernardini. São

Paulo: Hucitec- Unesp, 1990

BARTHOLO, Therezinha. Raul Pompéia e as variantes d’O Ateneu. O Estado de São Paulo, 17 out. 1971.

. Raul Pompéia: comentários da Bíblia. Jornal do Brasil, 17 nov. 1973. 
BARTHOLO, Therezinha. Raul Pompéia: no desenho, a outra face de um talento. Jornal do Brasil, 19 dez. 1975.

BAUDELAIRE, Charles. Poesia e prosa. Rio de Janeiro: Nova Aguilar, 2002.

BENJAMIM, Walter. Tese sobre Filosofia da História. São Paulo: Ática, 1985.

Histoire littéraire et science de la littérature. In: Poesie et révolution. Traduit et preface de l' allemand par Maurice de Gandillac. Paris: Denoel, 1971. p.7-14.

. O conceito de arte no romantismo alemão. Tradução de Márcio Seligmann silva. São Paulo: Edusp; Iluminuras, 1993.

. O conceito de crítica de arte no Romantismo alemão. Tradução, prefácio e notas de Márcio Seligmann Silva. São Paulo: M. Fontes, 1999.

BENSE, Max. Pequena estética. São Paulo: Perspectiva, 1975.

; WALTER, Elisabeth. La Semiótica, Guia alfabética. Barcelona: Anagrama, 1975.

BEUVE, Sainte. De la Littérature industrialle. Revue des Deux Mondes, Paris, Sept. 1839.

BRAGA, Raul. Raul Pompéia: o caifás. Boletim de Ariel, Rio de Janeiro, p. 210-214, maio 1936.

BRANDÃO, Roberto de Oliveira. Figuras de linguagem. São Paulo: Ática, 1989.

BRAYNER, Sônia. Labirinto do espaço romanesco. Rio de Janeiro: MEC, 1979.

BROCA, Brito. A vida literária no Brasil - 1900. Rio de Janeiro: J.Olympio, 1975. . Raul Pompéia. São Paulo: Melhoramentos, [19__].

BRUGGER, Walter. Dicionário de filosofia. São Paulo: Herder, 1962.

CAPAZ, Camil. Raul Pompéia - Biografia. Rio de Janeiro: Gryphos, 2001.

CASTELLO, João Aderaldo. Raul Pompéia: O Ateneu e o romance modernista. Anhembi, São Paulo, v.15, n.45, p. 472-482, ago. 1954.

CARISOMO, A. Berenouer. Como se analisa um texto literário. Buenos Aires: Scpena, 1969.

CAROLLO, Cassiana Lacerda. Decadentismo e simbolismo no Brasil: crítica e poética/seleção e representação. Rio de janeiro: Mec, 1981.

CARPEAUX, Otto Maria. História da literatura universal. Rio de Janeiro, v. V, 1993. 
CARRETEN, Fernando L.; LARA, Cecília. Manual de explicação de textos. São Paulo: Centro Universitário, 1962.

CARVALHAL, Tânia Franco. Literatura Comparada. São Paulo: Ática, 1992.

CASTELLO, José Aderaldo. Aspectos do romance brasileiro. Rio de Janeiro: Mec, 1975.

CHARTIER, Roger. A aventura do livro: do leitor ao navegador. Tradução de Reginaldo C.C. de Moraes. São Paulo: Edunesp, 1997.

. Os desafios da escrita. Tradução de Fulvia M. L. Moretto. São Paulo: Edusp, 2002.

CITELLI, Adilson. Romantismo. São Paulo: Ática. 1992.

COARACY, Vivaldo. Memórias da cidade do Rio de Janeiro. São Paulo: Edusp; Belo Horizonte: Itatiaia,1988.

COUTINHO, Afrânio. (Org.). Obra crítica de Araripe Júnior (1888 - 1894). Rio: MEC Casa Rui Barbosa, 1960. v. II.

. Caminhos do pensamento crítico. Rio de Janeiro: Pallas, 1980. v. I, II.

. O impressionismo e a obra de Raul Pompéia. Convivência. Rio de Janeiro: v.3, n.3, p.5-18, [19__].

. O impressionismo no Brasil: Pompéia. In: RECEPÇÃO de Afrânio Coutinho na Academia Brasileira de Letras. Rio de Janeiro: ABL, 1962.

COUTINHO, Eduardo. Raul Pompéia: obras. Rio de Janeiro: Civilização Brasileira, 1984. (Col. Fortuna Crítica, 7).

CUDDON, John. A Dictionary of Literary Terms. Middelsex: Penguin, 1977.

DA CAL, Ernesto Guerra. Língua e ensino de Eça de Queiroz. Rio de Janeiro:Edusp, 1969.

DEBRET, Jean Baptiste. Viagem pitoresca e histórica ao Brasil. Tradução de Sérgio Milliet. Belo Horizonte: Itatiaia; São Paulo: Edusp, 1978. v. I, II. Tomo I.

DURAND, Gilbert. Figuras mythiques et visages de l'oeuvre: de la mythocritique à la mythanalyse. Paris: Berg International, 1979.

ECO, Umberto. Os limites da interpretação. São Paulo: Perspectiva, 1999. . Apocalípticos e integrados. São Paulo: Perspectiva, 2001. 
EDMUNDO, Luiz. Recordações do Rio antigo. Rio de Janeiro: Conquista, 1956. . A tradição sempre nova. São Paulo: Ática, 1976. . Antologia do folclore brasileiro. São Paulo, M. Fontes, 1959. . Luiz. Locuções tradicionais do Brasil. Rio de janeiro: MEC; Funarte: [s.n.], 1977. . Luiz. O Rio de Janeiro do meu tempo. Rio de Janeiro: Nacional, 1938. v. I, II, III.

ELIADE, Mircea. Mito e realidade.São Paulo: Perspectiva,1986.

FREIXEIRO, Fábio. Análise de texto. Littera. Rio de Janeiro.

FREYRE, Gilberto. Jornais, história e psicologia. In: Retalhos de jornais velhos. Rio de Janeiro: J. Olympio, 1964.

FRIEDRICH, Hugo. Estrutura da lírica moderna. São Paulo: Duas Cidades, 1978.

GANDELMAN, Claude. Le regard dans le texte. Paris: Méridiens - Klincksiec, 1986.

GENETTE, Gérard. Discurso da narrativa. 3. ed. Tradução de Fernando Cabral Martins. Lisboa: Veja, 1995.

GOMES, Eugênio. Aspectos do romance brasileiro. Salvador: Progresso, 1958.

HOLANDA, Sérgio Buarque de. Raízes do Brasil. Rio de Janeiro: J. Olympio, 1989.

HUGO, Victor. Do Grotesco e do Sublime: tradução do Prefácio de Cromwell. Tradução de e notas de Cecília Berretim. São Paulo: Perspectiva, 1988.

IVO, Lêdo. O universo poético de Raul Pompéia. Rio de Janeiro: São José, 1963.

JAKOBSON, Roman. Etal Poétique - revue de théorie et d' analyse littéraires. Paris: Seuil, 1984. . Lingüística e comunicação. 15. ed. Tradução de Izidoro Blikstein e José Paulo Paes. São Paulo: Cultrix, 1987.

JUBRAN, Clélia C. A. S. A poética narrativa de O Ateneu. Tese (Doutorado) - Universidade de São Paulo, São Paulo, 1980. (mimeografada).

JUNG, C. G. A natureza da psique. 4. ed. Petrópolis: Vozes, 1998.

KOTHE, F. O herói. 2. ed. São Paulo: Ática, 1987.

LESKY, A. A tragédia grega. São Paulo: Perspectiva, 1976. 
LIMA, Herman. Escritores caricaturistas. In: História da caricatura no Brasil. Rio de Janeiro: J. Olympio, 1963. V. 4, p.1667-1694.

LINHARES, Termístocles. Apresentação. In: Raul Pompéia: trechos escolhidos. Rio de Janeiro: Agir, 1957.

LISBOA, J. I. de Almeida. MAKTUB! Jornal do Comércio, Rio de Janeiro, 1948.

LIZKA, James J. Caricature: the question of ideology. In: The Semiotic of myth: a critical study of the symbol. Bloomington; Indianápolis: Indiana University Press, 1989.

LOTMAN, Y. M. Sobre algumas dificuldades de princípio na descrição estrutural de um texto. In: SCHNAIDERMAN, B. (Org.) Semiótica russa. Tradução de Aurora F. Bernardini. São Paulo: Perspectiva, 1979.

. A estrutura do texto artístico. Lisboa: Estampa, 1978.

. Universe of mind. Indianapolis: University Press, 1990.

LYOTARD, Jean François. O inumano: considerações sobre o tempo. Tradução de Ana Cristina Seabra e Elisabete Alexandre. Lisboa: Stampa, 1988.

MARTINS, Heitor. As Canções sem metro, cosmologia do malogro. O Estado de São Paulo, 16 jun. 1990.

MATOS, Keila. A arte e a técnica da produção científica. Goiânia: Ed. da UCG; Universa, 2004.

MEYER, Marlyse. Folhetins: uma história. São Paulo: Cia. de Letras, 1996.

MIGUEL, Pereira Lúcia. Prosa de ficção (1870 a 1920). 3. ed. Rio de Janeiro: J. Olympio, 1962. p 107-118.

MONTELLO, Josué. Diário da manhã. Rio de janeiro: Nova Fronteira, 1984.

. Diário da tarde. Rio de Janeiro: Nova Fronteira, 1987.

MOREIRA, Virgílio Moretzsohn. Pompéia nas orlas da eternidade. In: POMPÉIA, Raul.

Crônicas do Rio. Rio de Janeiro: Secretaria Municipal de Cultura, Departamento Geral de Documentação e Informação Cultural, Divisão de Editoração, 1996. p. 9-13.

MORIER, Henri. Dictionnaire de poétique et de rhetorique. [França]: Pressses Universitaire de France, 1977. 
MURICY, Andrade. Raul Pompéia. In: Panorama do movimento simbolista brasileiro. 2.ed. Brasília: INL, 1973. V. 1. p.227-239. (Literatura Brasileira, 12).

NASCIMENTO, Danilo de Oliveira. Dossiê Sérgio: o ateneu como romance de formação. Campinas: [s.n.], 2000.

NEGROPONTE, Nicholas. A vida digital. 2. ed. São Paulo: Cia. das Letras, 1995.

PAIVA, Maria Helena de Novais. Contribuição para uma estilística da ironia. Lisboa: Centro de Estudos Filológicos, 1961.

PARANHOS, Haroldo. História do romantismo no Brasil. São Paulo: Cultura Brasileira, 1937. v. VII.

PAZ, Octavio. Signos e rotação. São Paulo: Perspectiva, 1976.

PERRONE MOISES, Leyla. Retórica e paixão. São Paulo: Brasiliense; Edusp, 1988.

POE, Edgar Allan. Graham's magazine, November, 1846. In: THE COMPLETE Works of Edgar Allan Poe. Edited by James A. Harrison . New York: AMS Press Inc., 1956, p.104-109. (Marginalia, vol. XVI.).

POMPÉIA, Raul. Sel. notas, est. biogr. hist. e crít. Mário Curvello. São Paulo: Abril Educação, 1981. (Literatura comentada).

. As jóias da coroa. São Paulo: Nova Alexandria, 1997.

. Canções sem metro. In: COUTINHO, Afrânio (Org.). Obras completas. Rio de Janeiro: Civilização Brasileira; Oficina Literária Afrânio Coutinho; Fename, 1982. V.4. (Vera Cruz, 324c).

. Crônicas do Rio. Rio de Janeiro: Sec. Municipal de Cultura, 1996.

. O Ateneu. Rio de Janeiro: F. Alves, 1976.

. Trechos escolhidos. 2.ed. Rio de Janeiro: Agir, 1960. (Nossos clássicos, 8).

PORTELLA, Eduardo. Literatura e realidade nacional. Rio de Janeiro: Tempo Brasileiro, 1975.

POUD, Ezra. ABC da literatura. São Paulo: Cultrix, 1978.

PROENÇA, M. Cavalcanti. Estudos literários. Rio de Janeiro: [s.n.], 1982.

RAMOS, Maria Luisa. Psicologia e estética de Raul Pompéia. Tese (Doutorado) Universidade Federal de Minas Gerais, Belo Horizonte, 1957. 
RANGEL, Genaro. Semeadura e colheita. Belo Horizonte: O Lutador, 1979.

RIBEIRO, João. Frases feitas. Rio de Janeiro: F. Alves, 1960.

RIBEIRO, José Alcides. Ficção brasileira e imprensa periódica na década de setenta: palimpsesto, hipertexto e alegoria. Estudos, Goiânia, v. 30, n. 3, p. 347-714, mar. 2003. . Imprensa e ficção no século XIX: Edgar Allan Poe e A narrativa de Arthur Gordon Pym. São Paulo: Ed. da Universidade Estadual Paulista, 1996.

O perfil literário e jornalístico do Correio Mercantil: literatura, jornalismo e hipertexto. [s.l.: s.n.], 2005.

. Texto verbal e imagem visual em O Ateneu de Raul Pompéia: uma poética radical na ficção em jornais. Estudos, Goiânia, v.28, n.3, p.371-392, maio/jun. 2001.

RIMBAUD, Arthur. Iluminuras, gravuras coloridas. Tradução, notas e ensaio de Rodrigo Garcia Lopes e Maurício Arruda Mendonça. São Paulo: Iluminuras, 2002.

RIZZINI, Carlos. O livro, o jornal e a tipografia no Brasil: 1500-1822. Rio de Janeiro, Kosmos, 1946. ROIG, Adrien. Modernismo e realismo. Rio de Janeiro: Presença, 1981.

SAINT-HILAIRE, Auguste de. Viagem pelas províncias do Rio de Janeiro e de Minas Gerais. Tradução de Vivaldi Moreira. Belo Horizonte: Itatiaia; São Paulo: Edusp, 1975.

SAMPAIO, Márcio. A litografia em Minas Gerais. In: 25 ANOS de litografia de arte em Minas Gerais. Juiz de Fora; Fundação Cultural Alfredo Ferreira Lage; Belo Horizonte: Secretaria do Estado de Cultura; Rede Globo Minas, 1986.

SANTIAGO, Silviano. O Ateneu: contradições e perquirições. In: . Uma literatura nos trópicos. São Paulo: Perspectiva, 1978.

SANTOS, Maria Terezinha da Consolação Teixeira dos. De como a educação torna-se palco no romance brasileiro: (uma tentativa de interpretação de O Ateneu de Raul Pompéia). São Paulo: [s.n.], 1988.

SCHMIDT, Afonso. O canudo: Raul Pompéia em São Paulo. São Paulo: Clube do Livro, 1963. SCHWARTZ, Roberto. A sereia e o desconfiado. Rio de Janeiro: Civilização Brasileira, 1965. SODRÉ, Nelson Werneck. História da imprensa no Brasil. Rio de Janeiro: Manad, 1999. 
TINHORÃO, José Ramos. Os romances em folhetins no Brasil: 1830 a atualidade. São Paulo: Duas Cidades, 1994.

TRAVANCAS, Isabel. O livro no jornal. Cotia [S.l.]: Ateliê, 2001.

URBINA, Nicasio. La significatión del género.Ediciones Universales, 1991.

VASSALO, Lúcia et al. A narrativa ontem e hoje. Rio de Janeiro: Tempo Brasileiro, 1984.

VENTURA, Roberto. Literatura e identidade nacional: Raul Pompéia e os percalços do nacionalismo brasileiro. São Paulo, 1991.

VÍTOR, Nestor. Obra crítica. vol.I. Rio de Janeiro: Rui Barbosa, 1969. v. I.

WALTER, Robert. Rogue's progress studies in the picaresque novel. Cambridge: Harvard University Press, 1965.

WEBER, João Hernesto. A nação e o paraíso. Florianópolis: Ed. da UFSC, 1997. 


\section{ANEXOS}

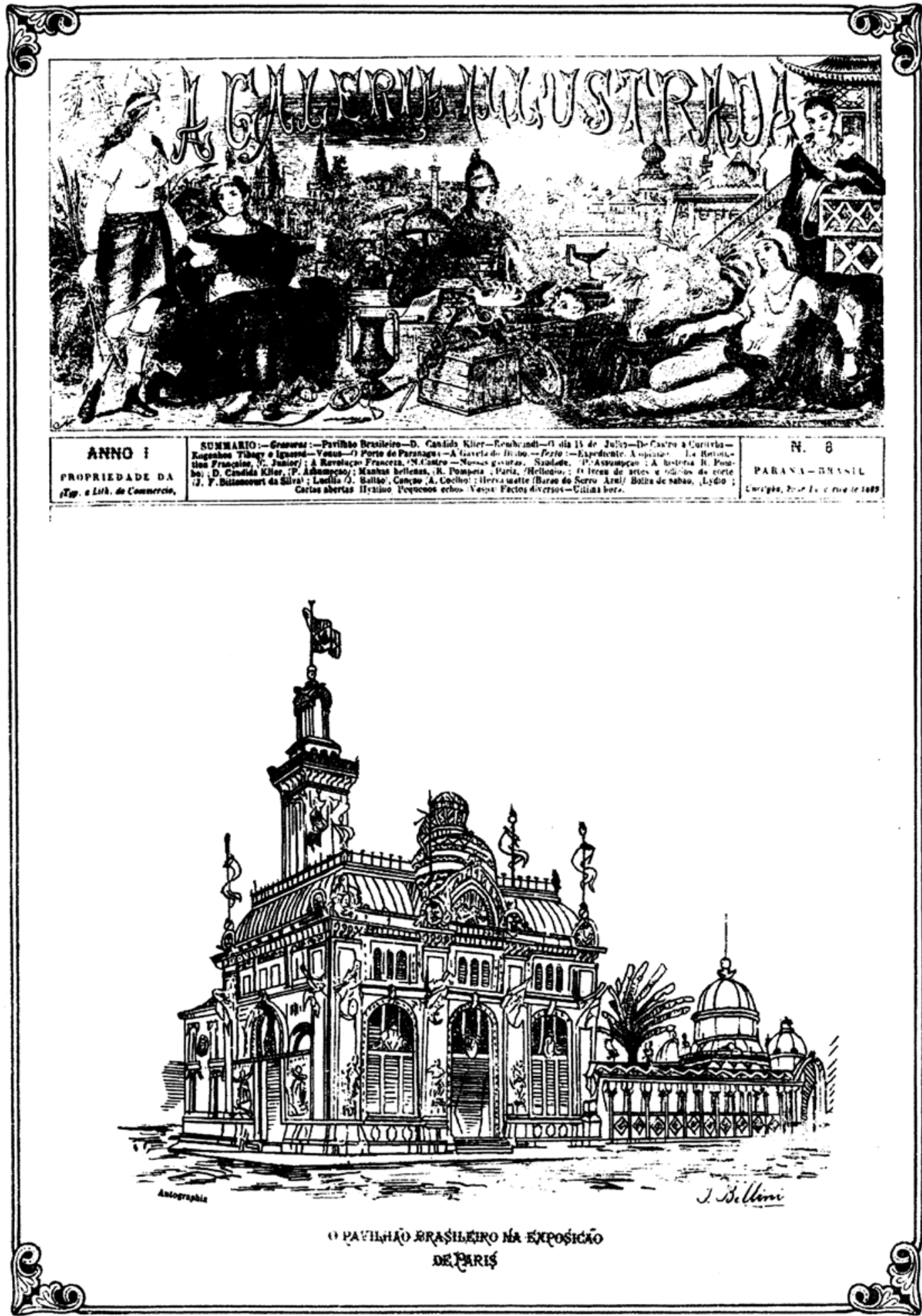

Figura 1: Capa da Revista A Galeria Illustrada 

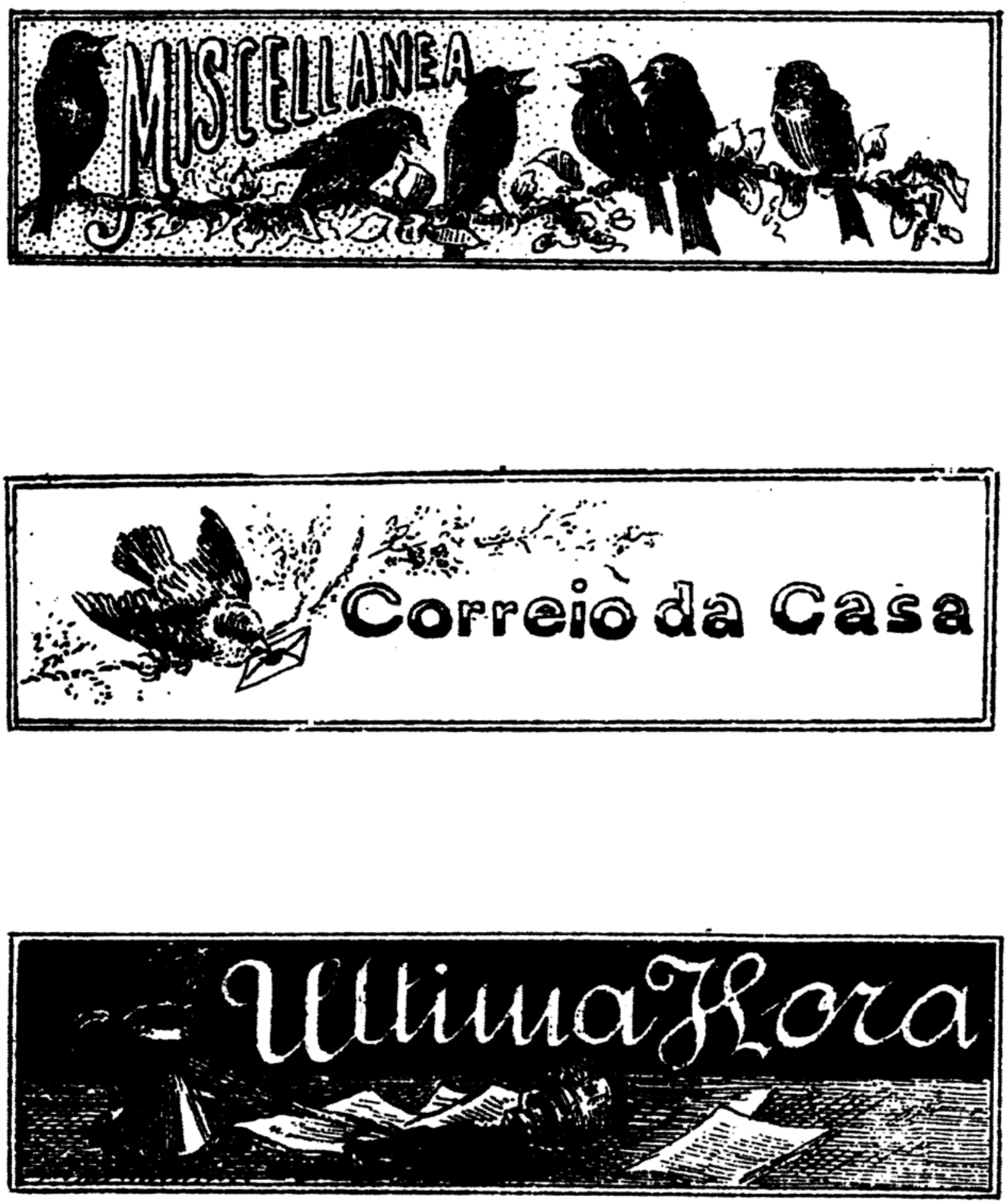

Figura 2: Vinhetas da Revista A Galeria Illustrada 


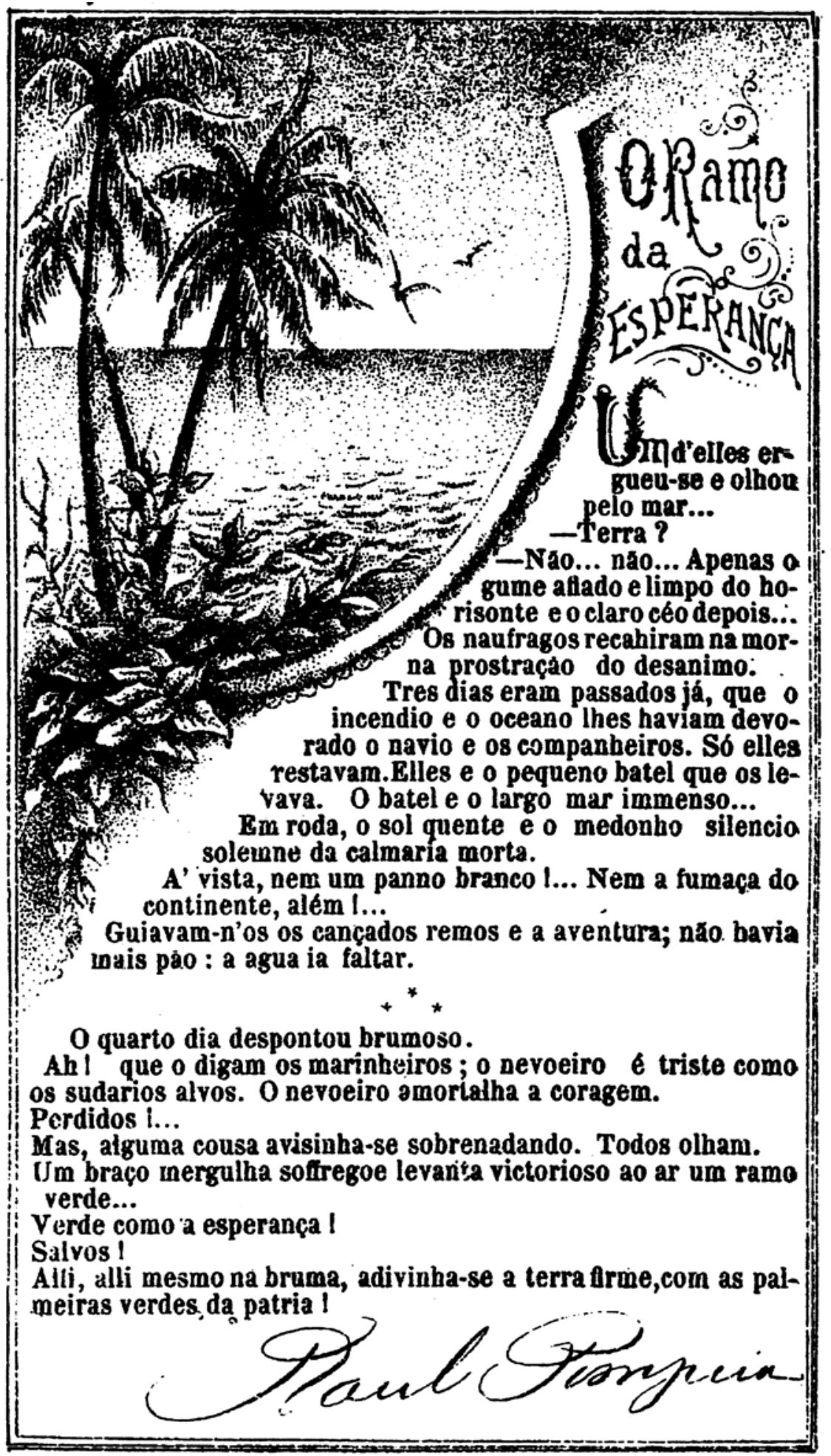

Figura 3: Canções sem Metro: Ramo da esperança.

Fonte: Revista A Galeria Illustrada, n. 4, 20 nov. 1888 


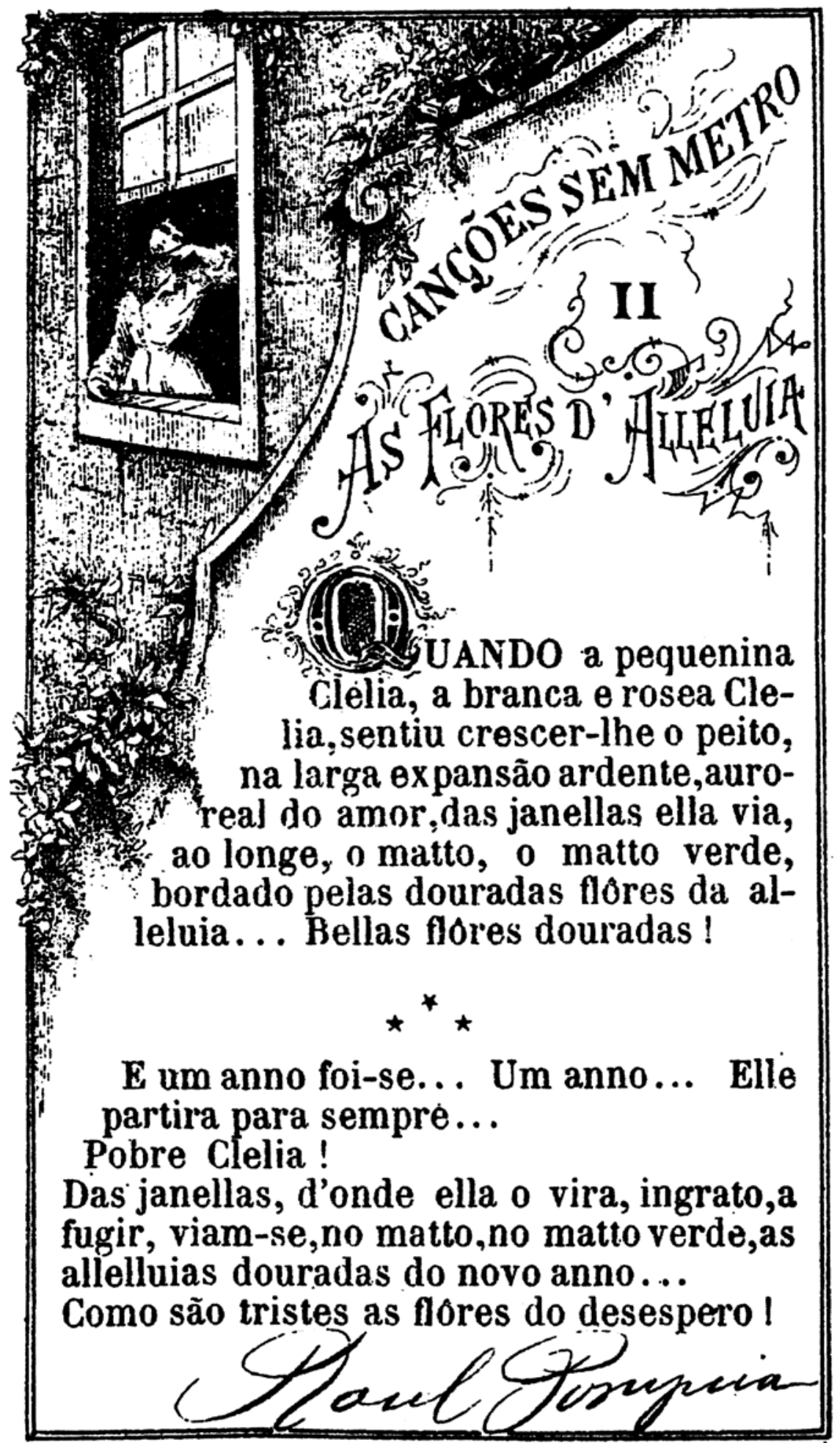

Figura 4: Canções sem Metro: As flores D’Aleluia.

Fonte: Revista A Galeria Illustrada, n. 12, 30 nov. 1888. 


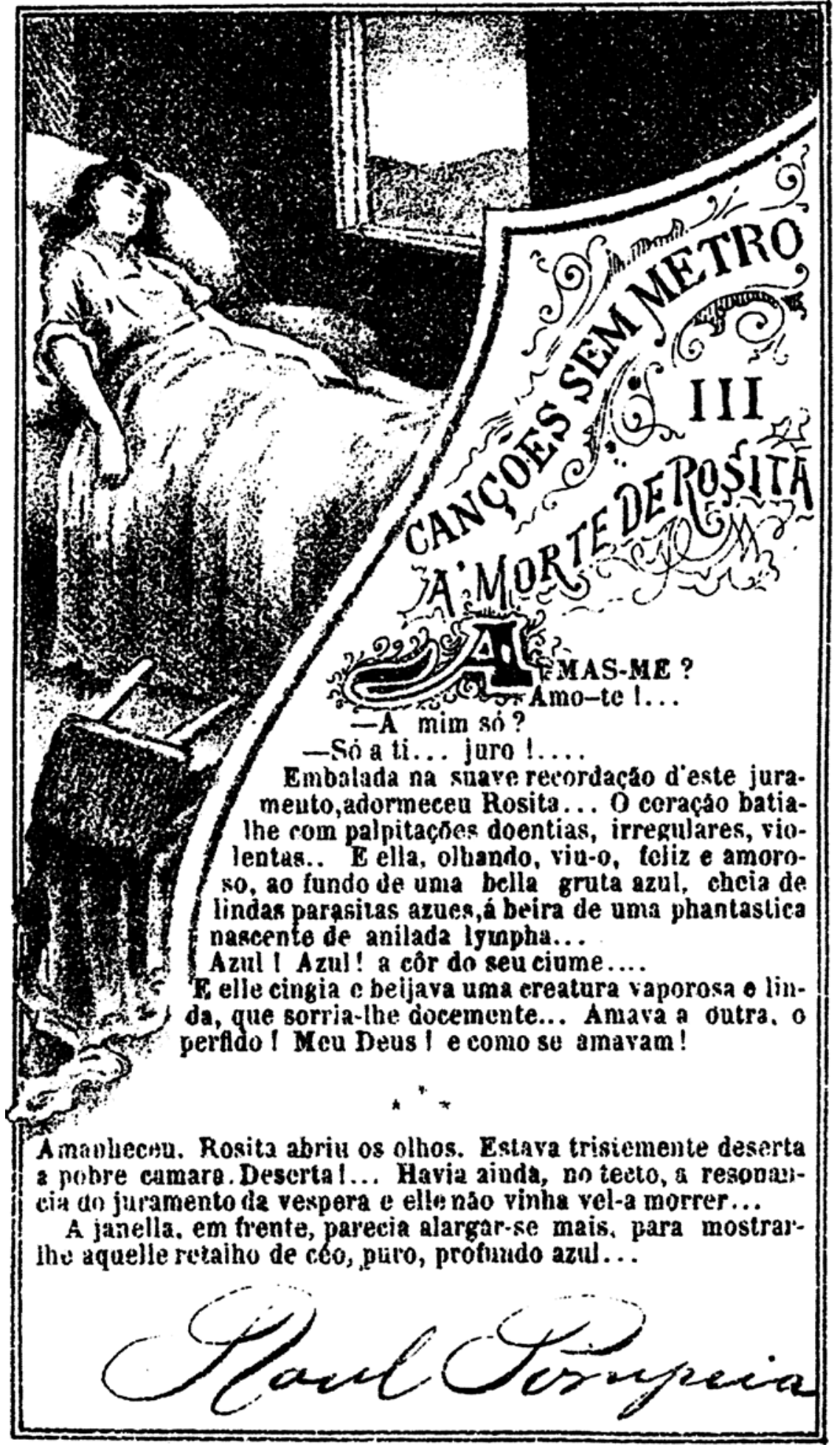

Figura 5: Canções sem Metro: A morte de Rosita.

Fonte: Revista A Galeria Illustrada, n. 19, 10 dez. 1888. 


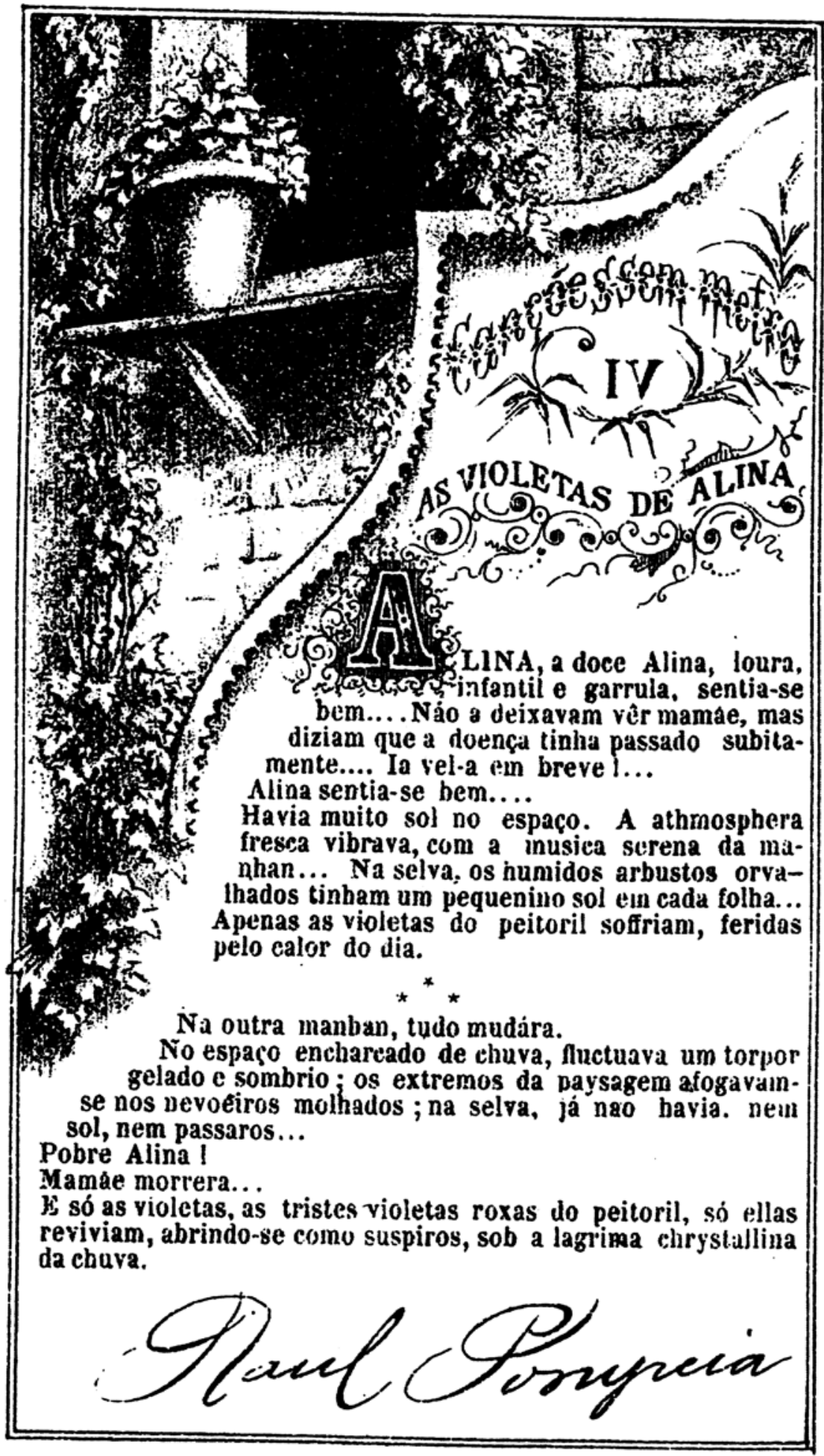

Figura 6: Canções sem Metro: As violetas de Alina.

Fonte: Revista A Galeria Illustrada, n. 28, 20 dez. 1888. 


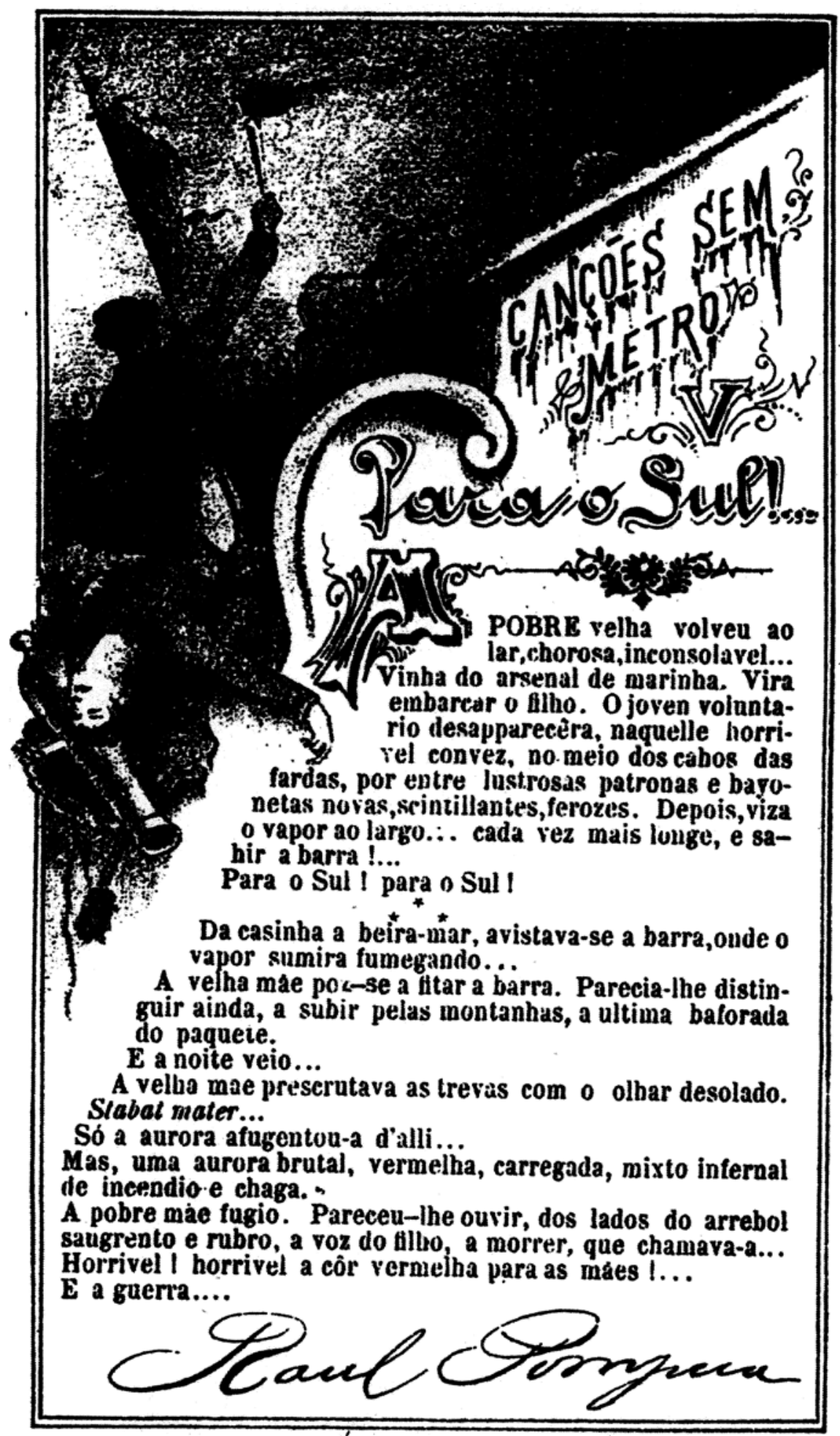

Figura 7: Canções sem Metro: Para o Sul!

Fonte: Revista A Galeria Illustrada, n. 36, 30 dez. 1888. 


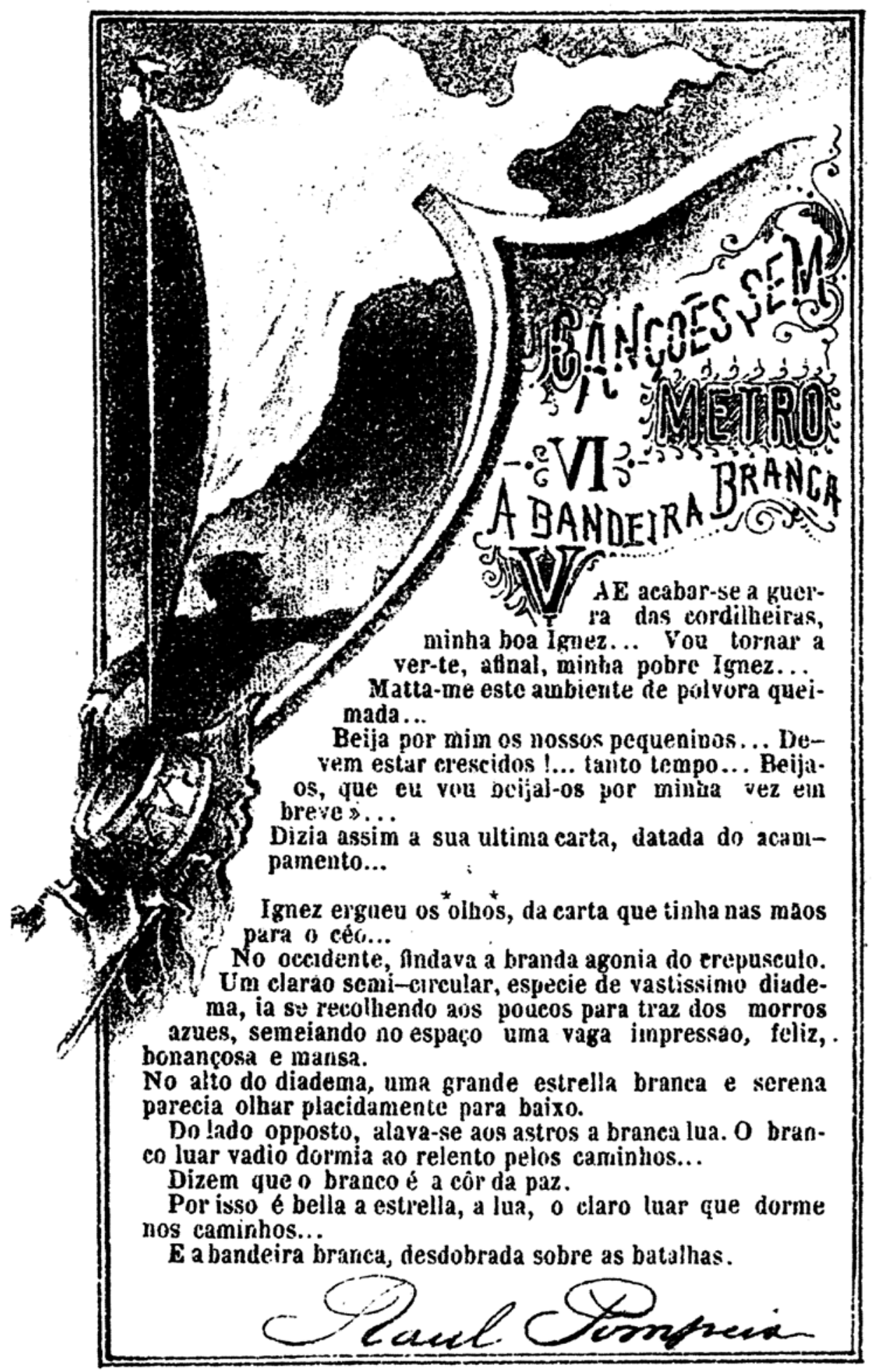

Figura 8: Canções sem Metro: A Bandeira Branca.

Fonte: Revista A Galeria Illustrada, n. 44, 10 jan. 1889. 


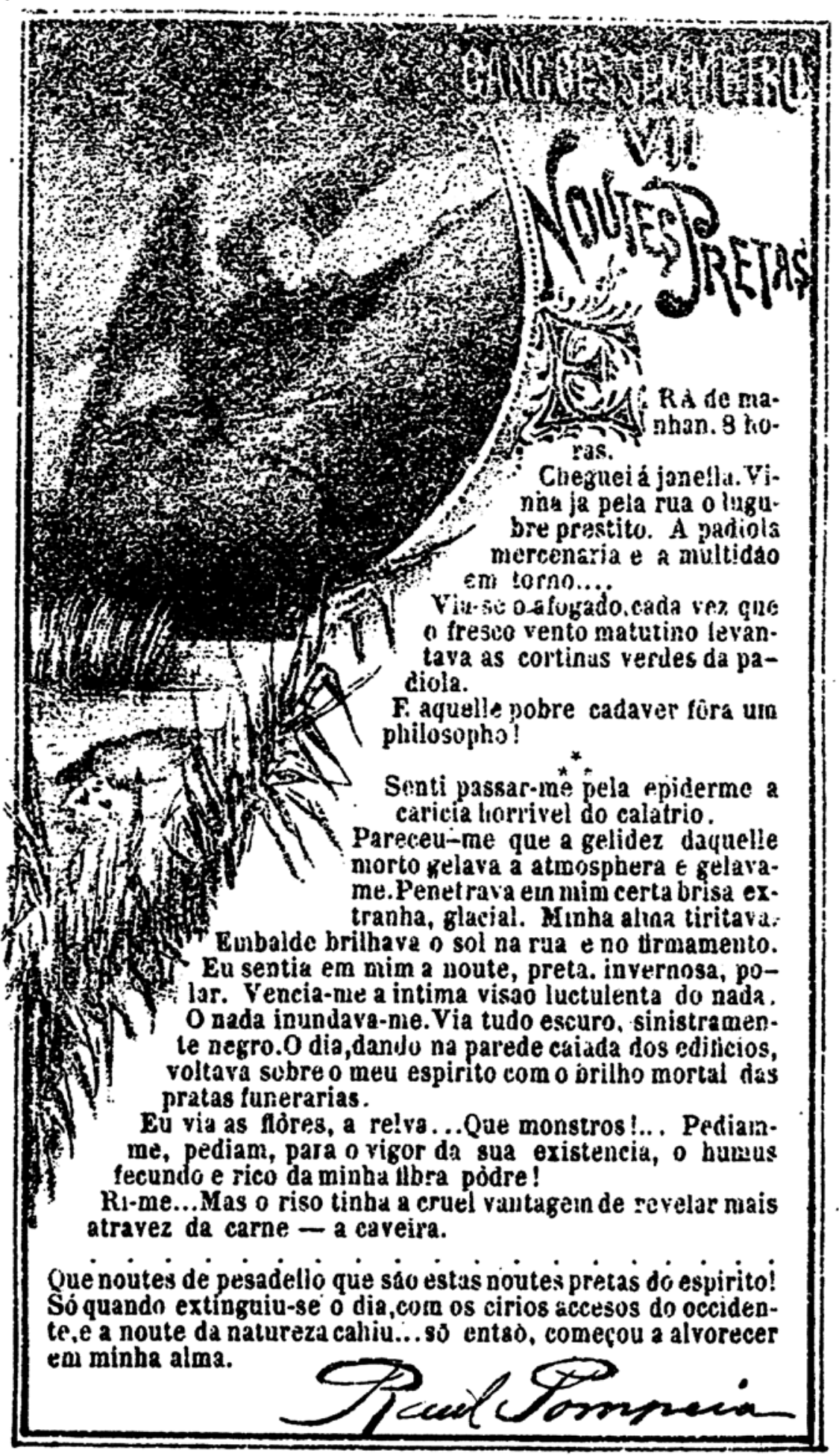

Figura 9: Canções sem Metro: Noutes Pretas.

Fonte: Revista A Galeria Illustrada, n. 51, 20 jan. 1889. 


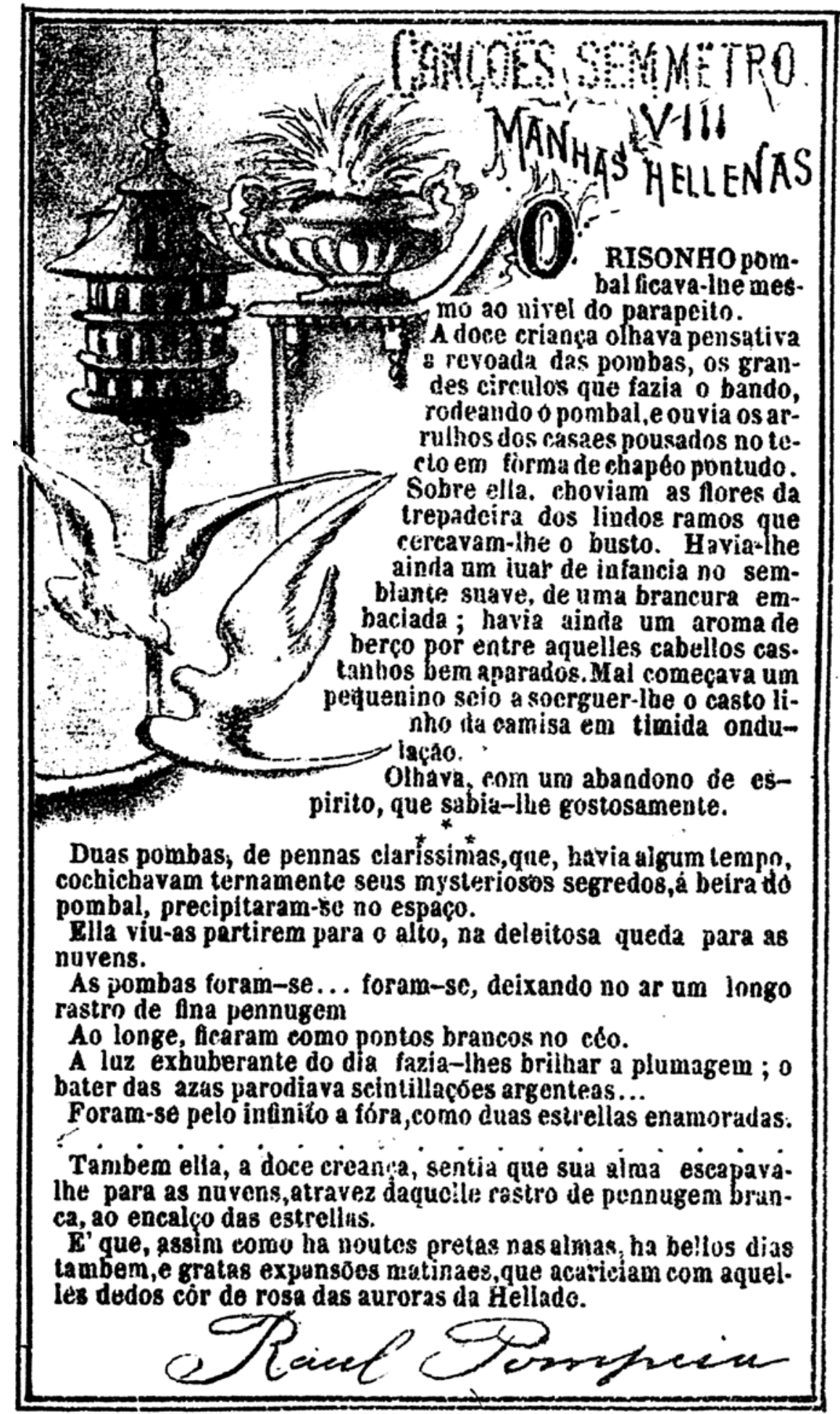

Figura 10: Canções sem Metro: Manhãs Hellenas.

Fonte: Revista A Galeria Illustrada, n. 61, 20 fev. 1889. 


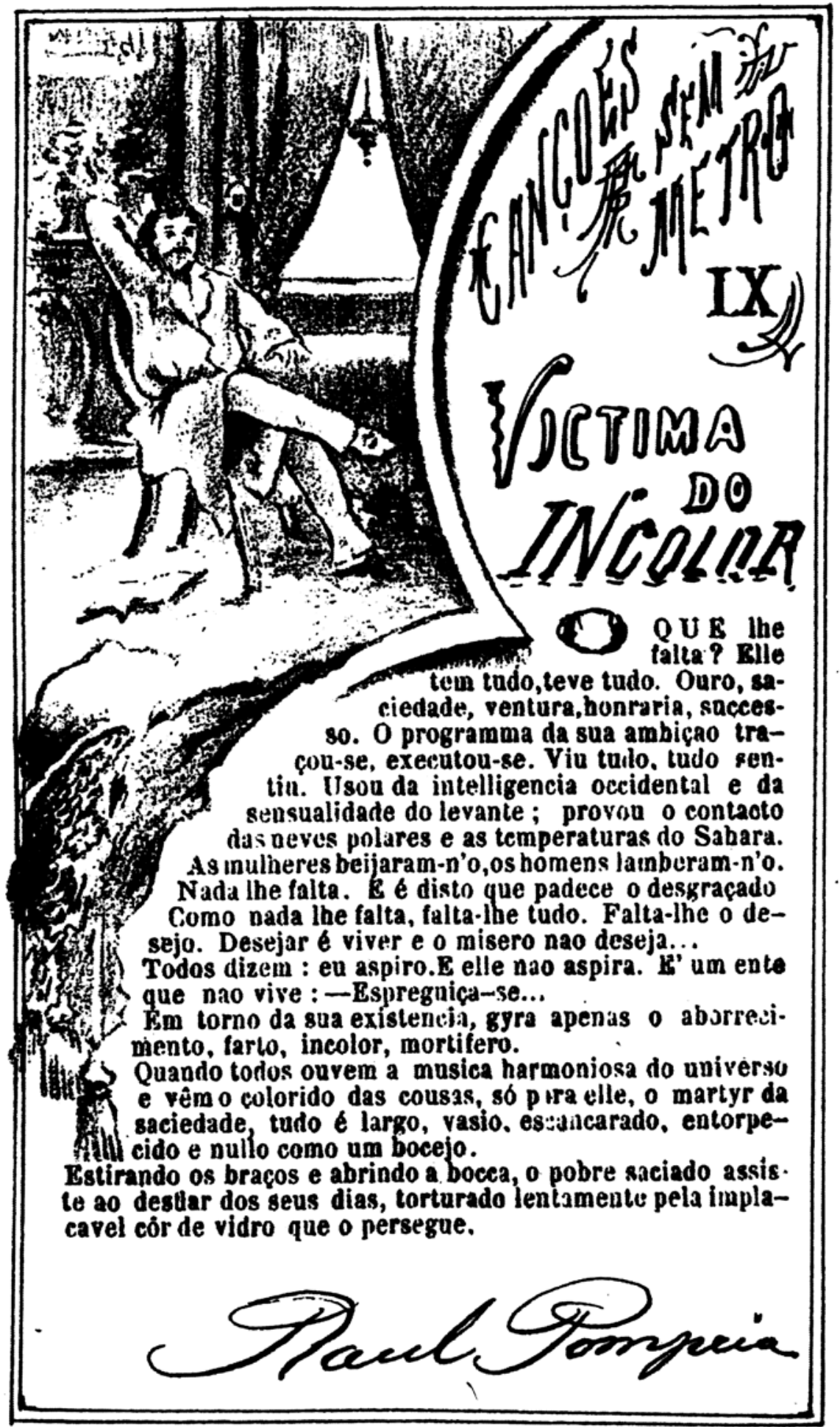

Figura 11: Canções Sem Metro: Victima do Incolor.

Fonte: Revista A Galeria Illustrada, n. 76, 30 mar. 1889. 


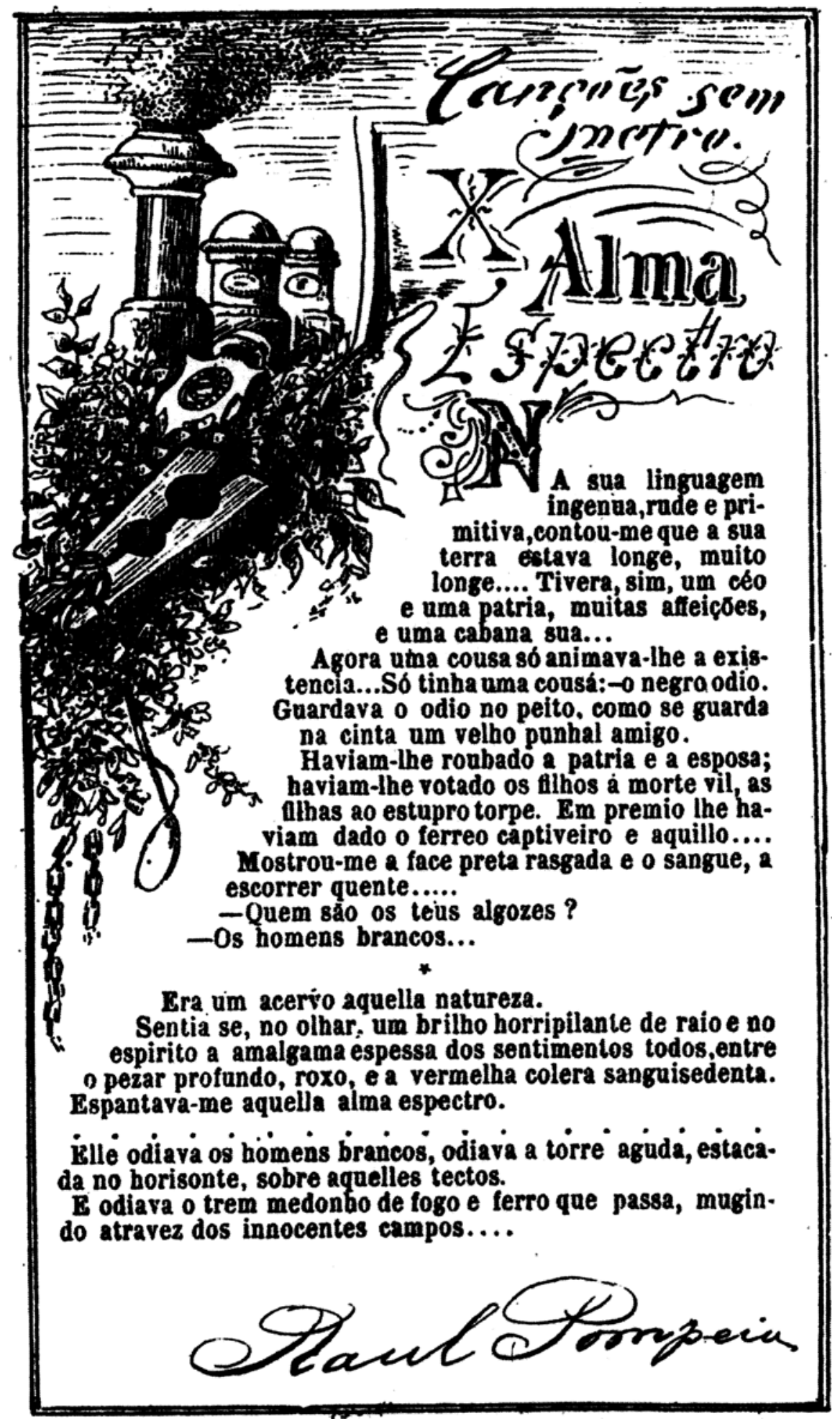

Figura 12: Canções sem Metro: Alma Espectro.

Fonte: Revista A Galeria Illustrada, n. 84, 10 abr. 1889. 